Nevada

Environmental

Restoration

Project

\title{
Corrective Action Decision Document for Corrective Action Unit 516: Septic Systems and Discharge Points Nevada Test Site, Nevada
}

Controlled Copy No::

Revision No.: 1

April 2004

Approved for public release; further dissemination unlimited.

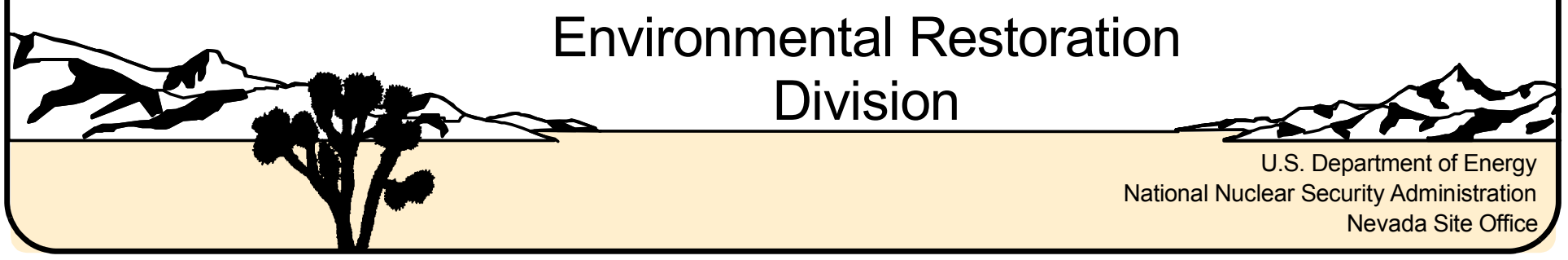


Available for public sale, in paper, from:

U.S. Department of Commerce

National Technical Information Service

5285 Port Royal Road

Springfield, VA 22161

Phone: 800.553 .6847

Fax: 703.605.6900

Email: orders@ntis.gov

Online ordering: http://www.ntis.gov/ordering.htm

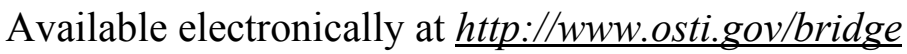

Available for a processing fee to U.S. Department of Energy and its contractors, in paper, from:

\section{U.S. Department of Energy}

Office of Scientific and Technical Information

P.O. Box 62

Oak Ridge, TN 37831-0062

Phone: 865.576 .8401

Fax: 865.576.5728

Email: reports@adonis.osti.gov

Reference herein to any specific commercial product, process, or service by trade name, trademark, manufacturer, or otherwise, does not necessarily constitute or imply its endorsement, recommendation, or favoring by the United States Government or any agency thereof or its contractors or subcontractors. 


\title{
CORRECTIVE ACTION DECISION DOCUMENT FOR CORRECTIVE ACTION UNIT 516: SEPTIC SYSTEMS AND DISCHARGE POINTS NEVADA TEST SITE, NEVADA
}

\author{
U.S. Department of Energy \\ National Nuclear Security Administration \\ Nevada Site Office \\ Las Vegas, Nevada
}

Controlled Copy No.:

Revision No.: 1

April 2004

Approved for public release; further dissemination unlimited. 


\section{CORRECTIVE ACTION DECISION DOCUMENT FOR CORRECTIVE ACTION UNIT 516: SEPTIC SYSTEMS AND DISCHARGE POINTS NEVADA TEST SITE, NEVADA}

Approved by: Signature Approved

Date: $\underline{4-26-04}$

Kevin Cabble, Acting Project Manager

Industrial Sites Project

Approved by: Signature Approved

Date: $4-26-04$

Janet Appenzeller-Wing, Acting Division Director

Environmental Restoration Division 


\section{Table of Contents}

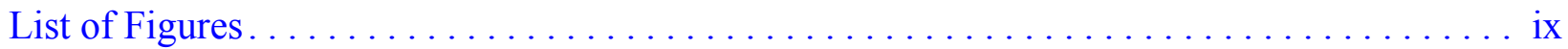

List of Tables. . . . . . . . . . . . . . . . . . . . . . . . . . .

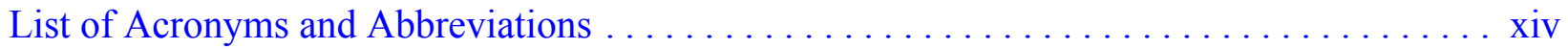

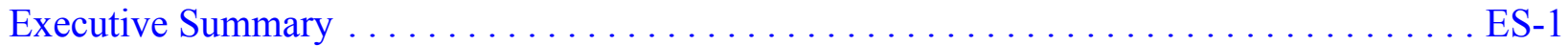

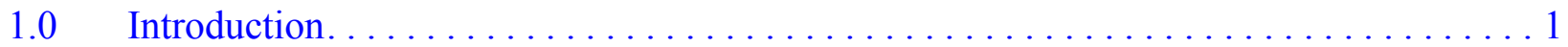

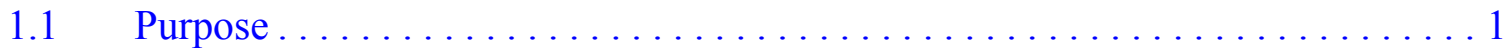

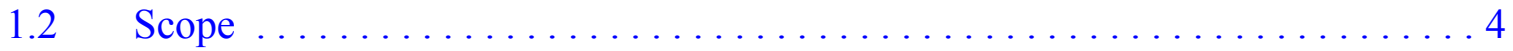

1.3 Corrective Action Decision Document Contents . . . . . . . . . . . . . 4

$2.0 \quad$ Corrective Action Investigation Summary $\ldots \ldots \ldots \ldots \ldots \ldots \ldots \ldots \ldots \ldots$

$2.1 \quad$ Investigation Activities. . . . . . . . . . . . . . . . . . . . 7

2.1.1 CAS 03-59-01, Bldg 3C-36 Septic System . . . . . . . . . . 11

2.1.2 CAS 03-59-02, Bldg 3C-45 Septic System . . . . . . . . . . . 13

2.1.3 CAS 06-51-01, Sump and Piping ................. 16

2.1.4 CAS 06-51-02, Clay Pipe and Debris...................... 18

2.1.5 CAS 06-51-03, Clean Out Box and Piping. . . . . . . . . . . . 19

2.1.6 CAS 22-19-04, Vehicle Decontamination Area . . . . . . . . . . . . . 20

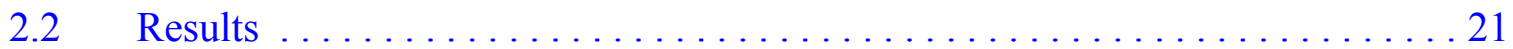

2.2.1 Summary of Characterization Data. . . . . . . . . . . . . 22

2.2.1.1 CAS 03-59-01, Bldg 3C-36 Septic System ........ . 23

2.2.1.2 CAS 03-59-02, Bldg 3C-45 Septic System . . . . . . . . 23

2.2.1.3 CAS 06-51-01, Sump and Piping ............ 24

2.2.1.4 CAS 06-51-02, Clay Pipe and Debris .......... 24

2.2.1.5 CAS 06-51-03, Clean Out Box and Piping ........ 24

2.2.1.6 CAS 22-19-04, Vehicle Decontamination Area . . . . . 25

2.2.2 Data Assessment Summary . . . . . . . . . . . . . . . . . . . . 25

$2.3 \quad$ Need for Corrective Action . . . . . . . . . . . . . . . . . . . 25

2.3.1 CAS 03-59-01, Bldg 3C-36 Septic System . . . . . . . . . . 26

2.3.2 CAS 03-59-02, Bldg 3C-45 Septic System . . . . . . . . . . . 26

2.3.3 CAS 06-51-01, Sump and Piping .................. 27

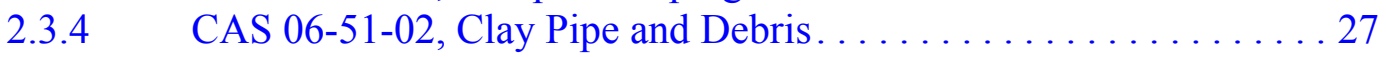

2.3.5 CAS 06-51-03, Clean Out Box and Piping. . . . . . . . . . 28

2.3.6 CAS 22-19-04, Vehicle Decontamination Area .............. 28

$3.0 \quad$ Evaluation of Alternatives . . . . . . . . . . . . . . . . . . . . . . . . . . . . . . . . 29

3.1 Corrective Action Objectives . . . . . . . . . . . . . . . . . . . . . 29

$3.2 \quad$ Screening Criteria. . . . . . . . . . . . . . . . . . . . . . . . 29

3.2.1 Corrective Action Standards . . . . . . . . . . . . . . . . . 31

3.2.2 Remedy Selection Decision Factors . . . . . . . . . . . . . . . 32

3.3 Development of Corrective Action Alternatives ................. 34 


\section{Table of Contents (Continued)}

3.3.1 Alternative 1 - No Further Action...................... 35

3.3.1.1 CAS 06-51-02, Clay Pipe and Debris ........... 35

3.3.1.2 CAS 22-19-04, Vehicle Decontamination Area ...... 35

3.3.2 Alternative 2 - Clean Closure ....................... 35

3.3.2.1 CAS 03-59-01, Bldg 3C-36 Septic System ......... 36

3.3.2.2 CAS 03-59-02, Bldg 3C-45 Septic System .......... 37

3.3.2.3 CAS 06-51-01, Sump and Piping .............. 38

3.3.2.4 CAS 06-51-03, Clean Out Box and Piping ......... 39

3.3.3 Alternative 3 - Close in Place with Administrative Controls ...... . 39

3.3.3.1 CAS 03-59-01, Bldg 3C-36 Septic System .......... 39

3.3.3.2 CAS 03-59-02, Bldg 3C-45 Septic System ......... 40

3.3.3.3 CAS 06-51-01, Sump and Piping ............. 42

3.3.3.4 CAS 06-51-03, Clean Out Box and Piping ......... 43

$3.4 \quad$ Evaluation and Comparison of Alternatives..................... 43

$4.0 \quad$ Recommended Alternative . . . . . . . . . . . . . . . . . . . . . . . . . . . . . . . . . 49

$5.0 \quad$ References............................................. 53

\section{Appendix A - Corrective Action Investigation Report for CAU 516}

A.1.0 Introduction. . . . . . . . . . . . . . . . . . . . . . . . . . . . . . . . . A-1

A.1.1 Objectives ....................................

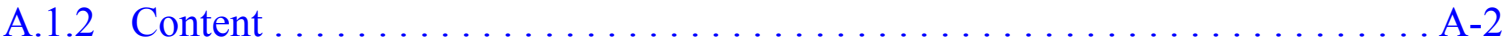

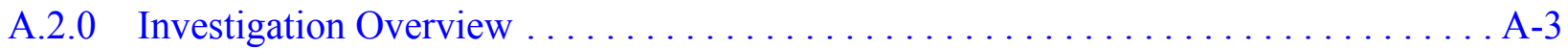

A.2.1 Preliminary Conceptual Model. ......................... A-4

A.2.2 Sample Locations ............................... A-4

A.2.3 Investigation Activities. .......................... A-4

A.2.3.1 Field Screening . . . . . . . . . . . . . . . . . .

A.2.3.2 Intrusive Investigation Activities . . . . . . . . . . . A-6

A.2.3.3 Waste Characterization....................... A-7

A.2.3.3.1 Visual Assessment ....................... A-7

A.2.3.3.2 Waste Characterization Sampling ............ A-8

A.2.4 Laboratory Analytical Information. ..................... A-8

A.2.5 Comparison to Preliminary Action Levels . . . . . . . . . . . . . . . . . A-9

A.2.6 Geology . . . . . . . . . . . . . . . . . . . . . . . . . . . . . A-10

A.2.7 Hydrology. . . . . . . . . . . . . . . . . . . . . . . . A-11

A.3.0 CAS 03-59-01, Bldg 3C-36 Septic System ....................... A-12

A.3.1 Corrective Action Investigation . . . . . . . . . . . . . . . . . . . A-12 


\section{Table of Contents (Continued)}

A.3.1.1 Deviations............................... A-12

A.3.2 Investigation Activities.............................. A-18

A.3.2.1 Field Screening ........................ A 18

A.3.2.2 Intrusive Investigation Activities $\ldots \ldots \ldots \ldots \ldots \ldots \ldots \ldots$ A-18

A.3.2.2.1 Initial Sampling . .................... A-18

A.3.2.2.2 Step-out Sampling . . . . . . . . . . . . . . . A-19

A.3.2.3 Waste Characterization...................... A-19

A.3.2.3.1 Visual Assessment ...................... A-19

A.3.2.3.2 Waste Characterization Sampling ............ A-20

A.3.2.4 Sample Analysis ............................. A-20

A.3.3 Analytes Detected Above Minimum Reporting Limits or

Minimum Detectable Concentrations. . . . . . . . . . . . . . . . . A-20

A.3.3.1 Total Volatile Organic Compound Analytical Results

for Soil Samples . . . . . . . . . . . . . . . . . . . A-21

A.3.3.2 Total Semivolatile Organic Compound Analytical

Results for Soil Samples. . . . . . . . . . . . . . . . . . . A-21

A.3.3.3 Total RCRA Metal Analytical Results for Soil Samples ........ A-22

A.3.3.4 Total Petroleum Hydrocarbon Analytical Results for Soil Samples . . . . . . . . . . . . . . . . . . . . . . . . A-22

A.3.3.5 Polychlorinated Biphenyl Analytical Results for Soil Samples ... A-22

A.3.3.6 Gamma Spectroscopy Analytical Results for Soil Samples .... . . A-22

A.3.3.7 Isotopic Plutonium Analytical Results for Soil Samples . . . . . . . A-22

A.3.3.8 Strontium-90 Analytical Results for Soil Samples. . . . . . . . . . A-22

A.3.4 Waste Characterization Analytical Results . . . . . . . . . . . . . A-22

A.3.5 Contaminants of Concern ........................... A-24

A.3.6 Nature and Extent of Contamination . . . . . . . . . . . . . . . . . . A-24

A.3.7 Revised Conceptual Site Model . . . . . . . . . . . . . . . . . . . . . A-24

A.4.0 CAS 03-59-02, Bldg 3C-45 Septic System ...................... A-27

A.4.1 Corrective Action Investigation . . . . . . . . . . . . . . . . . A-27

A.4.1.1 Deviations............................ A-28

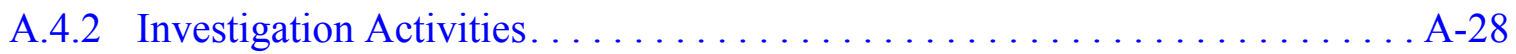

A.4.2.1 Field Screening ........................... A-28

A.4.2.2 Visual Assessment ....................... A-28

A.4.2.3 Intrusive Investigation Activities . . . . . . . . . . . . A-35

A.4.2.3.1 Initial Sampling . . . . . . . . . . . . . A-35

A.4.2.4 Step-out Sampling. ......................... A-36

A.4.2.5 Waste Characterization...................... A-36

A.4.2.5.1 Waste Characterization Sampling ............. A-36

A.4.2.6 Sample Analysis . ........................ A-37

A.4.3 Analytes Equal to or Greater than Minimum Reporting Limits.......... A-38 


\section{Table of Contents (Continued)}

A.4.3.1 Total Volatile Organic Compound Analytical

Results for Soil Samples. . . . . . . . . . . . . . . A-38

A.4.3.2 Total Semivolatile Organic Compound Analytical

Results for Soil Samples. . . . . . . . . . . . . . . A-38

A.4.3.3 Total Metal Analytical Results for Soil Samples . . . . . . . . . . . A-38

A.4.3.4 Total Petroleum Hydrocarbon Analytical Results for Soil Samples . . . . . . . . . . . . . . . . . . . . A-39

A.4.3.5 Polychlorinated Biphenyl Analytical Results for Soil Samples ... A-39

A.4.3.6 Gamma Spectroscopy Analytical Results for Soil Samples . . . . . A A-39

A.4.3.7 Isotopic Plutonium Analytical Results for Soil Samples . . . . . . . A-39

A.4.3.8 Strontium-90 Analytical Results for Soil Samples . . . . . . . . . . . . A-42

A.4.3.9 Waste Characterization Sample Results . . . . . . . . . . . . . . . . A-42

A.4.4 Contaminants of Concern . . . . . . . . . . . . . . . . . . A-44

A.4.5 Nature and Extent of Contamination . . . . . . . . . . . . . . . . . . . A A-48

A.4.6 Revised Conceptual Site Model . . . . . . . . . . . . . . . . . . . . . . A-48

A.5.0 CAS 06-51-01, Sump and Piping . . . . . . . . . . . . . . . . A-49

A.5.1 Corrective Action Investigation . . . . . . . . . . . . . . . . . . A-49

A.5.1.1 Deviations . . . . . . . . . . . . . . . . . . . . . . . . A-49

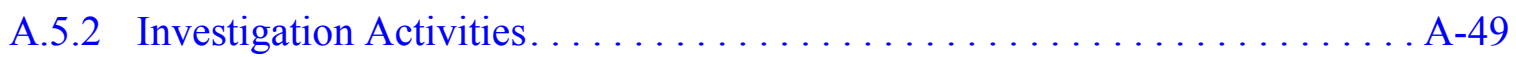

A.5.2.1 Field Screening . . . . . . . . . . . . . . . . . A-49

A.5.2.2 Intrusive Investigation Activities . . . . . . . . . . . A $\ldots$-52

A.5.2.3 Waste Characterization...................... A-52

A.5.2.3.1 Visual Assessment . . . . . . . . . . . . . A-53

A.5.2.4 Sample Analysis . . . . . . . . . . . . . . . . . . . A-53

A.5.3 Analytical Results Equal to or Greater than Minimum Reporting Limits . . . A-53

A.5.3.1 Total Volatile Organic Compound Analytical

Results for Soil Samples. . . . . . . . . . . . . . . . . A-54

A.5.3.2 Total Semivolatile Organic Compound Analytical

Results for Soil Samples. . . . . . . . . . . . . . . . . . . A A-54

A.5.3.3 Total RCRA Metal Analytical Results for Soil Samples . . . . . . . A-54

A.5.3.4 Total Petroleum Hydrocarbon Analytical Results

for Soil Samples . . . . . . . . . . . . . . . . . . A-54

A.5.3.5 Polychlorinated Biphenyl Analytical Results for Soil Samples . . A A-54

A.5.3.6 Gamma Spectroscopy Analytical Results for Soil Samples . . . . . A-56

A.5.3.7 Isotopic Plutonium Analytical Results for Soil Samples . . . . . . . A-56

A.5.3.8 Strontium-90 Analytical Results for Soil Samples. . . . . . . . . . . A-56

A.5.4 Contaminants of Concern . . . . . . . . . . . . . . . . . . . . A-57

A.5.5 Nature and Extent of Contamination . . . . . . . . . . . . . A-57

A.5.6 Revised Conceptual Site Model . . . . . . . . . . . . . . . . A-58 


\section{Table of Contents (Continued)}

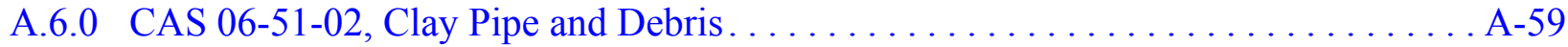

A.7.0 CAS 06-51-03, Clean Out Box and Piping. . . . . . . . . . . . . . . A-61

A.7.1 Corrective Action Investigation . . . . . . . . . . . . . . . A-61

A.7.1.1 Deviations............................... A

A.7.2 Investigation Activities. . . . . . . . . . . . . . . . . . . . A-61

A.7.2.1 Field Screening. . . . . . . . . . . . . . . . . . A A-61

A.7.2.2 Intrusive Investigation Activities . . . . . . . . . . . . . A-63

A.7.2.2.1 Initial Sampling . . . . . . . . . . . . A-63

A.7.2.2.2 Step-Out Sampling . . . . . . . . . . . . A-63

A.7.2.3 Waste Characterization. ... . . . . . . . . . . . . . . . . . . A-64

A.7.2.3.1 Visual Assessment . . ................ A-64

A.7.2.3.2 Waste Characterization Sampling ... . . . . . . . . A-64

A.7.2.4 Sample Analysis . . . . . . . . . . . . . . . . . . . . . . . A-65

A.7.3 Analytes Detected Equal to or Greater than Minimum Reporting Limits . . . A-65

A.7.3.1 Total Volatile Organic Compound Analytical

Results for Soil Samples. . . . . . . . . . . . . . . . . A-65

A.7.3.2 Total Semivolatile Organic Compound Analytical

Results for Soil Samples. . . . . . . . . . . . . . . . . A-66

A.7.3.3 Total RCRA Metal Analytical Results for Soil Samples . . . . . . . A-66

A.7.3.4 Total Petroleum Hydrocarbon Analytical Results for Soil Samples . . . . . . . . . . . . . . . . . . . . . A-66

A.7.3.5 Polychlorinated Biphenyl Analytical Results for Soil Samples . . A A-68

A.7.3.6 Pesticide Analytical Results for Soil Samples . . . . . . . . . . . . A A-68

A.7.3.7 Gamma Spectroscopy Analytical Results for Soil Samples . . . . . A A-70

A.7.3.8 Isotopic Plutonium Analytical Results for Soil Samples . . . . . . . . A-70

A.7.3.9 Strontium-90 Analytical Results for Soil Samples. . . . . . . . . . . A A-70

A.7.3.10 Waste Characterization Analytical Results. . . . . . . . . . . . . A-71

A.7.4 Contaminants of Concern ...................... A-71

A.7.5 Nature and Extent of Contamination . . . . . . . . . . . . . A A-71

A.7.6 Revised Conceptual Site Model . . . . . . . . . . . . . . . . . . . . . . . A-72

A.8.0 CAS 22-19-04, Vehicle Decontamination Area . . . . . . . . . . . . . . . . . A-73

A.8.1 Corrective Action Investigation $\ldots \ldots \ldots \ldots \ldots \ldots \ldots \ldots \ldots \ldots \ldots \ldots \ldots$

A.8.1.1 Deviations ............................. . $\ldots \ldots$

A.8.2 Investigation Activities. . . . . . . . . . . . . . . . . . . . $\ldots \ldots$

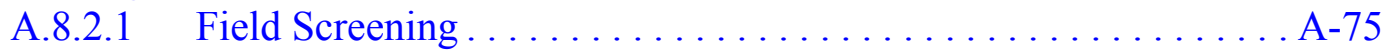

A.8.2.2 Intrusive Investigation Activities . . . . . . . . . . A-76

A.8.2.3 Waste Characterization..................... A-76

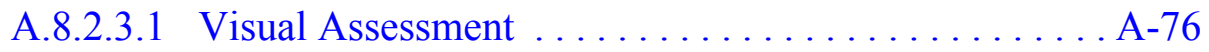

A.8.2.4 Sample Analysis . . . . . . . . . . . . . . . . A-76 


\section{Table of Contents (Continued)}

A.8.3 Analytes Detected Above Minimum Reporting Limits . . . . . . . . . . . . A-76

A.8.3.1 Total Volatile Organic Compound Analytical

Results for Soil Samples. . . . . . . . . . . . . . . . . A-77

A.8.3.2 Total Semivolatile Organic Compound Analytical

Results for Soil Samples. . . . . . . . . . . . . . . . . . A-77

A.8.3.3 Total RCRA Metal Analytical Results for Soil Samples . . . . . . . A-78

A.8.3.4 Total Petroleum Hydrocarbon Analytical Results for Soil Samples . . . . . . . . . . . . . . . . . . . A-78

A.8.3.5 Polychlorinated Biphenyl Analytical Results for Soil Samples . . . A-78

A.8.3.6 Gamma Spectroscopy Analytical Results for Soil Samples . . . . . A A-79

A.8.3.7 Isotopic Uranium and Isotopic Plutonium Analytical Results for Soil Samples . . . . . . . . . . . . . . . . . . . . . . A-79

A.8.3.8 Strontium-90 Analytical Results for Soil Samples. . . . . . . . . . A-79

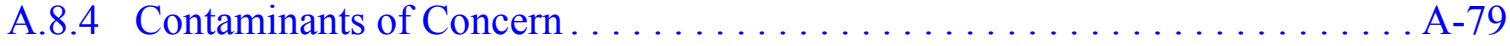

A.8.5 Revised Conceptual Site Model . . . . . . . . . . . . . . . . . . . . A A-80

A.9.0 Waste Management. . . . . . . . . . . . . . . . . . . . . A-82

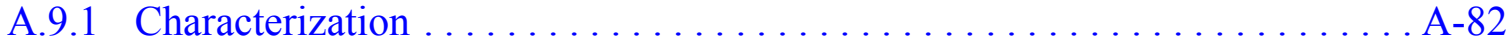

A.9.2 Waste Streams . . . . . . . . . . . . . . . . . . . . . . . . . . A-82

A.9.3 Investigation-Derived Waste Generated. . . . . . . . . . . . . . A-82

A.10.0 Quality Assurance. . . . . . . . . . . . . . . . . . . . . . A-84

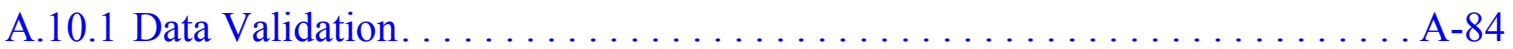

A.10.1.1 Tier I Evaluation. . . . . . . . . . . . . . . . . . . A-84

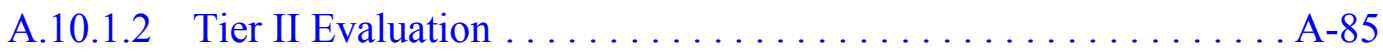

A.10.1.3 Tier III. . . . . . . . . . . . . . . . . . . . . A-86

A.10.2 Quality Control Samples . . . . . . . . . . . . . . . . . . . A-87

A.10.2.1 Field Quality Control Samples . . . . . . . . . . . . . . . . A-87

A.10.2.2 Laboratory Quality Control Samples . . . . . . . . . . . . . . A-88

A.10.3 Field Nonconformances . . . . . . . . . . . . . . . . . . . . . . . A-88

A.10.4 Laboratory Nonconformances . . . . . . . . . . . . . . . . A-88

A.11.0 Summary . . . . . . . . . . . . . . . . . . . . . . . . . .

A.12.0 References. . . . . . . . . . . . . . . . . . . . . . . . . A-91

\section{Appendix B - Data Assessment of Samples Results for CAU 516}

B.1.0 Data Assessment. . . . . . . . . . . . . . . . . . . . . . . . B-1

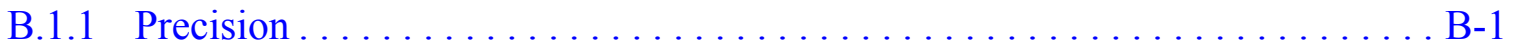

B.1.1.1 Precision for Chemical Analysis. . . . . . . . . . . . B-2 


\section{Table of Contents (Continued)}

B.1.1.2 Precision for Radiochemical Analysis . . . . . . . . . . . B-3

B.1.1.3 Precision Summary. . . . . . . . . . . . . . . . . . B-8

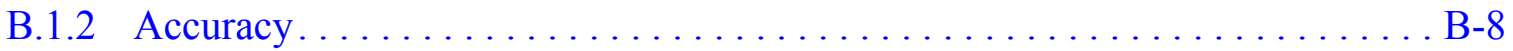

B.1.2.1 Accuracy for Chemical Analysis . . . . . . . . . . . . . B-8

B.1.2.2 Accuracy for Radiochemical Analysis . . . . . . . . . . . . . B-11

B.1.2.3 Accuracy Summary. ........................ B-14

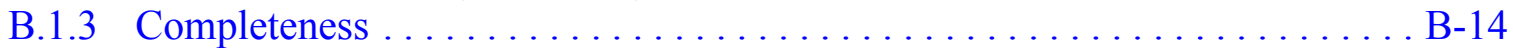

B.1.3.1 Completeness Summary . . . . . . . . . . . . . . . B-16

B.1.4 Rejected Data . . . . . . . . . . . . . . . . . . . . . . $\ldots$

B.1.5 Representativeness . . . . . . . . . . . . . . . . . . . B-23

B.1.6 Comparability. . . . . . . . . . . . . . . . . . . . . . . . B-23

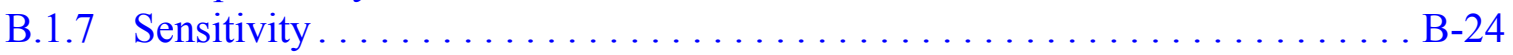

B.1.8 Reconciliation of Conceptual Site Model(s) to the Data . . . . . . . . . . B-24

B.1.8.1 Conceptual Site Models . . . . . . . . . . . . . . . . . . B-24

B.1.8.1.1 Septic System Conceptual Site Model . . . . . . . . . . . . B-24

B.1.8.1.2 Leachfield Conceptual Site Model . . . . . . . . . . . . B-25

B.1.8.1.3 Clean-Out Box Conceptual Site Model . . . . . . . . . B-26

B.1.8.1.4 Sump Conceptual Site Model . . . . . . . . . . . . B-26

B.1.8.1.5 Dry Well Conceptual Site Model . . . . . . . . . . . . . B-27

B.1.8.2 Contaminant Nature and Extent . . . . . . . . . . . . . B-28

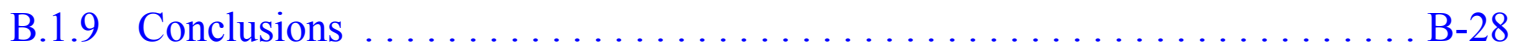

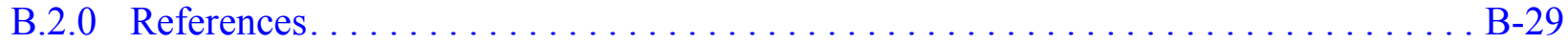

Appendix C - Cost Estimates for CAU 516

\section{Appendix D - Sample Location Coordinates for CAU 516}

D.1.0 Sample Location Coordinates. . . . . . . . . . . . . . . . . . D-1

D.1.1 CAS 03-59-01, Bldg 3C-36 Septic System . . . . . . . . . . . . . . . . D-1

D.1.2 CAS 03-59-02, Bldg 3C-45 Septic System . . . . . . . . . . . . . . . D-1

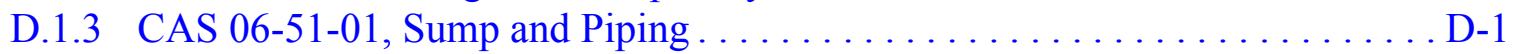

D.1.4 CAS 06-51-02, Clay Pipe and Debris................... D-1

D.1.5 CAS 06-51-03, Clean Out Box and Piping. . . . . . . . . . . . . . D-1

D.1.6 CAS 22-19-04, Vehicle Decontamination Area.................... D-2

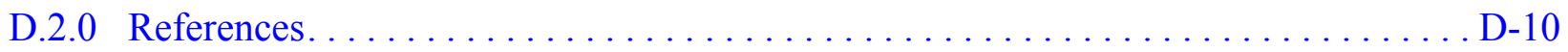

\section{Appendix E - Project Organization for CAU 516}

E.1.0 Project Organization . . . . . . . . . . . . . . . . . . . . . . . E-1 


\title{
Table of Contents (Continued)
}

\author{
Appendix F - NDEP Comments
}




\section{List of Figures}

Number

Title

Page

1-1 Nevada Test Site Location Map ............................. 2

1-2 CAU 516, Corrective Action Sites Location Map ..................... 3

4-1 CAU 516, CAS 03-59-01, Bldg 3C-36 Septic System, Recommended Closure Alternative: Clean Closure. . . . . . . . . . . . . . . . . . . . . 50

4-2 CAU 516, CAS 03-59-02, Bldg 3C-45 Septic System, Recommended Closure Alternative: Clean Closure. ................... 51

4-3 CAU 516, CAS 06-51-01, Sump and Piping, and CAS 06-51-03, Clean Out Box and Piping, Recommended Closure Alternative: Clean Closure . . . . . . . . 52

A.3-1 CAU 516, CAS 03-59-01, Bldg 3C-36 Septic System, Sample Locations...... . A-17

A.4-1 CAU 516, CAS 03-59-02, Bldg 3C-45 Septic System, Sample Locations...... . A-34

A.5-1 CAU 516, CAS 06-51-01, Sump and Piping, and CAS 06-51-03, Clean Out Box and Piping, Sample Locations . .................. A-51

A.6-1 CAU 516, CAS 06-51-02, Clay Pipe and Debris, Site of Debris Removal ..... A-60

A.8-1 CAU 516, CAS 22-19-04, Vehicle Decontamination Area, Sample Locations ... A-74

D.1-1 CAU 516, CAS 03-59-01, Bldg 3C-36 Septic System, GPS Coordinate Locations . . . . . . . . . . . . . . . . . . . . . . . . . . D-3

D.1-2 CAU 516, CAS 03-59-02, Bldg 3C-45 Septic System, GPS Coordinate Locations ................................. D-5

D.1-3 CAU 516, CAS 06-51-01, Sump and Piping, and CAS 06-51-03, Clean Out Box and Piping, GPS Coordinate Locations ................ D-7

D.1-4 CAU 516, CAS 22-19-04, Vehicle Decontamination Area GPS Coordinate Locations . . . . . . . . . . . . . . . . . . . . . D-9 


\section{List of Tables}

Number

Title

Page

1-1 CAU 516 Corrective Action Sites ..................... 4

2-1 Environmental Soil Sample Analyses Conducted at CAU $516 \ldots \ldots \ldots \ldots$

2-2 Waste Characterization Sample Analyses Conducted at CAU 516 . . . . . 10

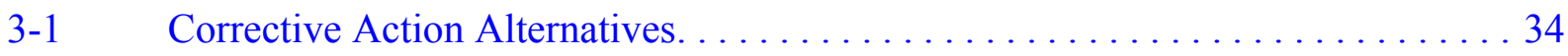

3-2 Detailed Evaluation of Alternatives for Corrective Action Unit 516 . . . . . . 44

3-3 Comparative Evaluation of Alternatives for Corrective Action Unit $516 \ldots \ldots$. . . 48

A.2-1 Corrective Action Investigation Activities Conducted at CAU $516 \ldots \ldots \ldots$. . A-6

A.2-2 Laboratory Analytical Parameters and Methods for CAU 516

Investigation Samples . . . . . . . . . . . . . . . . A-9

A.3-1 Samples Collected at CAS $03-59-01 \ldots \ldots \ldots \ldots \ldots \ldots \ldots \ldots \ldots \ldots \ldots$

A.3-2 Soil Sample Results for Total VOCs Equal to or

Greater than Minimum Reporting Limits at CAS 03-59-01 . . . . . . . . . . A A-21

A.3-3 Soil Sample Results for Total SVOCs Equal to or Greater than

Minimum Reporting Limits at CAS $03-59-01 \ldots \ldots \ldots \ldots \ldots \ldots \ldots$ A-21

A.3-4 Soil Sample Results for Total Metals Detected Equal to or Greater than

Minimum Reporting Limits at CAS $03-59-01 \ldots \ldots \ldots \ldots \ldots \ldots$ A-23

A.3-5 Soil Sample Results for Total Petroleum Hydrocarbons

Equal to or Greater than Minimum Reporting Limits at CAS 03-59-01 . . . . . A A-24

A.3-6 Soil Sample Results for Gamma-Emitting Radionuclides Equal to or

Greater than Minimum Detectable Concentrations at CAS 03-59-01 . . . . . . A A-25

A.3-7 Septic Tank Results Equal to or Greater than

Minimum Reporting Limits at CAS $03-59-01 \ldots \ldots \ldots \ldots \ldots \ldots$ A-26

A.4-1 Samples Collected at CAS $03-59-02 \ldots \ldots \ldots \ldots \ldots \ldots \ldots \ldots \ldots \ldots$. . . . . . . . . . 


\section{List of Tables (Continued)}

A.4-2 Soil Sample Results for Total VOCs Equal to or Greater than Minimum Reporting Limits at CAS 03-59-02.

A.4-3 Soil Sample Results for Total Metals Equal to or Greater than the Minimum Reporting Limits at CAS 03-59-02 . .

A.4-4 Soil Sample Results for TPH-DRO Equal to or Greater than Minimum Reporting Limits at CAS 03-59-02 . .

A.4-5 Soil Sample Results for Gamma-Emitting Radionuclides Equal to or Greater than Minimum Detectable Concentrations at CAS 03-59-02 . . . . . . A-43

A.4-6 Soil Sample Results for Isotopic Plutonium Equal to or Greater than Minimum Detectable Concentrations at CAS 03-59-02 . . . . . . . . . . . . . A-44

A.4-7 Septic Tank Sample Results for CAS 03-59-02 . . . . . . . . . . . . . . . . A-45

A.5-1 Samples Collected at CAS 06-51-01 ..................... A-50

A.5-2 Soil Sample Results for Total SVOCs Equal to or Greater than Minimum Reporting Limits at CAS 06-51-01 . . . . . . . . . . . . . . . . . A-54

A.5-3 Soil Sample Results for Total Metals Equal to or Greater than Minimum

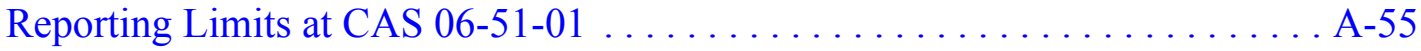

A.5-4 Soil Sample Results for TPH-DRO Equal to or Greater than Minimum Reporting Limits at CAS 06-51-01 . . . . . . . . . . . . . . . A-56

A.5-5 Soil Sample Results for Gamma-Emitting Radionuclides Equal to or Greater than Minimum Detectable Concentrations at CAS 06-51-01.

A.5-6 Soil Sample Results for Isotopic Plutonium Detected Equal to or Greater than Minimum Detectable Concentrations at CAS 06-51-01 . . . . . . A-58

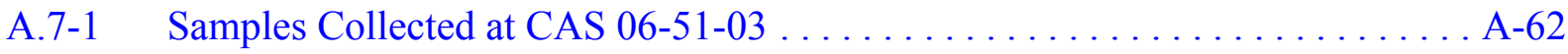




\section{List of Tables (Continued)}

A.7-2 Soil Sample Results for Total VOCs Equal to or Greater than Minimum Reporting Limits at CAS 06-51-03.

A.7-3 Soil Sample Results for Total SVOCs Equal to or Greater than Minimum Reporting Limits at CAS 06-51-03 . . . . . . . . . . . A-66

A.7-4 Soil Sample Results for Total RCRA Metals, Plus Beryllium Equal to or Greater than Minimum Reporting Limits at CAS 06-51-03 . . . . . . . . . A-67

A.7-5 Soil Sample Results for TPH-DRO Equal to or Greater than Minimum Reporting Limits at CAS 06-51-03 . . . . . . . . . . . . . . A-68

A.7-6 Soil Sample Result for PCBs Equal to or Greater than Minimum Reporting Limits at CAS 06-51-03 . . . . . . . . . . . . . . . . . . . . A A-69

A.7-7 Soil Sample Results for Pesticides Equal to or Greater than Minimum Reporting Limits at CAS 06-51-03 . . . . . . . . . A-69

A.7-8 Soil Sample Results for Gamma-Emitting Radionuclides Equal to or Greater than Minimum Detectable Concentrations at CAS 06-51-03 . . . . . A-70

A.7-9 Soil Sample Results for Isotopic Plutonium Equal to or Greater than Minimum Detectable Concentrations at CAS 06-51-03 . . . . . . . . . . . . . . . . A-71

A.8-1 Samples Collected from CAS $22-19-04 \ldots \ldots \ldots \ldots \ldots \ldots \ldots \ldots \ldots$ A $\ldots \ldots$. . . . .

A.8-2 Soil Sample Results for Total VOCs Equal to or Greater than Minimum Reporting Limits at CAS 22-19-04 . . . . . . . . . . . . . . . . . A-77

A.8-3 Soil Sample Results for Total RCRA Metals, Plus Beryllium Equal to or Greater than Minimum Reporting Limits at CAS 22-19-04 . . . . . . . . . . A A-78

A.8-4 Soil Sample Results for TPH-DRO Equal to or Greater than Minimum Reporting Limits at CAS 22-19-04 . . . . . . . . . . . . . . . . . A-79

A.8-5 Soil Sample Results for Gamma-Emitting Radionuclides Equal to or Greater than Minimum Detectable Concentrations at CAS 22-19-04 . . . . . . . A A-80 


\section{List of Tables (Continued)}

Number

Title

Page

A.8-6 Soil Sample Results for Isotopic Plutonium and Uranium Equal to or Greater than Minimum Detectable Concentrations at CAS 22-19-04 . . . . . . A-81

B.1-1 Chemical Analysis Precision Measurements for CAU $516 \ldots \ldots \ldots \ldots \ldots$. . . .

B.1-2 Laboratory Duplicate Precision of Radioanalytes . . . . . . . . . . . . . . . B-6

B.1-3 Matrix Spike/Matrix Spike Duplicate Precision for Radioanalytes . . . . . . . . . B-6

B.1-4 Laboratory Field Duplicate Precision for Radioanalytes . . . . . . . . . . . . . B-6

B.1-5 Laboratory Analysis Accuracy Measurements for CAU $516 \ldots \ldots \ldots \ldots \ldots$. . . . . 10

B.1-6 Radioanalyte Laboratory Control Sample Accuracy . . . . . . . . . . . . . . . . B B-13

B.1-7 Radioanalyte Matrix Spike Accuracy . . . . . . . . . . . . . . . . B-13

B.1-8 Chemical Completeness for CAU $516 \ldots \ldots \ldots \ldots \ldots \ldots \ldots \ldots \ldots \ldots \ldots$

B.1-9 Radiological Completeness for CAU $516 \ldots \ldots \ldots \ldots \ldots \ldots \ldots \ldots$

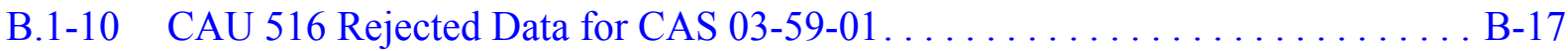

B.1-11 CAU 516 Rejected Data for CAS 03-59-02................... B-19

B.1-12 CAU 516 Rejected Data for CAS 06-51-01................. B-21

B.1-13 CAU 516 Rejected Data for CAS 06-51-03 . . . . . . . . . . . . B-22

B.1-14 CAU 516 Rejected Data for CAS 22-19-04................... B-22

D.1-1 Sample Location Coordinates for CAS 03-59-01 . . . . . . . . . . . . D-2

D.1-2 Sample Location Coordinates for CAS 03-59-02 . . . . . . . . . . . D-4

D.1-3 Sample Location Coordinates for CAS 06-51-01 . . . . . . . . . . . D-6

D.1-4 Sample Location Coordinates for CAS 06-51-03 .............. D-8

D.1-5 Sample Location Coordinates for CAS $22-19-04 \ldots \ldots \ldots \ldots \ldots \ldots \ldots$. . . . . 


\section{List of Acronyms and Abbreviations}

Am

bgs

CADD

CAI

CAIP

CAS

CAU

CFR

CLP

$\mathrm{cm}^{2}$

$\mathrm{COC}$

COLIWASA

COPC

CRDL

CSM

DOE

dpm

DQI

DQO

DRO

EPA

FADL

FD

FFACO

FSL

FSR
Americium

Below ground surface

Corrective Action Decision Document

Corrective Action Investigation

Corrective Action Investigation Plan

Corrective Action Site

Corrective Action Unit

Code of Federal Regulations

Contract Laboratory Program

Square centimeter

Contaminants of concern

Composite Liquid Waste Sampler

Contaminants of potential concern

Contract-required detection limit

Conceptual site models

U.S. Department of Energy

Disintegrations per minute

Data quality indicators

Data quality objectives

Diesel-range organics

U.S. Environmental Protection Agency

Field activity daily $\log$

Field duplicates

Federal Facility Agreement and Consent Order

Field-screening levels

Field-screening results 


\section{List of Acronyms and Abbreviations (Continued)}

\begin{tabular}{|c|c|}
\hline $\mathrm{ft}$ & Foot (feet) \\
\hline $\mathrm{ft}^{3}$ & Cubic feet \\
\hline gal & Gallon \\
\hline GPS & Global positioning system \\
\hline GRO & Gasoline-range organics \\
\hline HWAA & Hazardous Waste Accumulation Area \\
\hline IDW & Investigation-derived waste \\
\hline in. & Inch \\
\hline $\mathrm{K}-40$ & Potassium-40 \\
\hline LANL & Los Alamos National Laboratory \\
\hline LCS & Laboratory control samples \\
\hline LCSD & Laboratory control sample duplicates \\
\hline LD & Laboratory duplicate \\
\hline $\mathrm{MDC}$ & Minimum detectable concentration \\
\hline $\mathrm{mg} / \mathrm{kg}$ & Milligrams per kilogram \\
\hline $\mathrm{mi}$ & Mile \\
\hline mrem & Millirem \\
\hline MRL & Minimum reporting level \\
\hline MS & Matrix spike \\
\hline MSD & Matrix spike duplicate \\
\hline NAC & Nevada Administrative Code \\
\hline NAD & North American Datum \\
\hline NCRP & National Council on Radiation Protection and Measurement \\
\hline NDEP & Nevada Division of Environmental Protection \\
\hline NDWS & National Drinking Water Standards \\
\hline NIST & National Institute for Standards and Technology \\
\hline
\end{tabular}




\section{List of Acronyms and Abbreviations (Continued)}

\begin{tabular}{|c|c|}
\hline NNSA/NSO & $\begin{array}{l}\text { U.S. Department of Energy, National Nuclear Security Administration } \\
\text { Nevada Site Office }\end{array}$ \\
\hline NRS & Nevada Revised Statues \\
\hline NTS & Nevada Test Site \\
\hline PARCC & Precision, accuracy, representativeness, comparability, and completeness \\
\hline PAL & Preliminary action level \\
\hline PB & Preparation blanks \\
\hline PCB & Polychlorinated biphenyls \\
\hline $\mathrm{pCi} / \mathrm{g}$ & Picocuries per gram \\
\hline $\mathrm{pCi} / \mathrm{L}$ & Picocuries per liter \\
\hline POC & Performance objective criteria \\
\hline PPE & Personal protective equipment \\
\hline ppm & Parts per million \\
\hline PRG & Preliminary Remediation Goal \\
\hline $\mathrm{Pu}$ & Plutonium \\
\hline QA & Quality assurance \\
\hline QAPP & Quality Assurance Project Plan \\
\hline QC & Quality control \\
\hline RCRA & Resource Conservation and Recovery Act \\
\hline ROTC & Record of Technical Change \\
\hline RPD & Relative percent difference \\
\hline SDG & Sample delivery group \\
\hline Sr-90 & Strontium-90 \\
\hline SVOC & Semivolatile organic compounds \\
\hline TCLP & Toxicity characteristic leaching procedure \\
\hline TPH & Total petroleum hydrocarbons \\
\hline $\mathrm{U}$ & Uranium \\
\hline
\end{tabular}




\section{List of Acronyms and Abbreviations (Continued)}

UST Underground storage tanks

UTM Universal Transverse Mercator

VCP Vitrified clay pipe

VOC Volatile organic compounds

$\mathrm{yd}^{3} \quad$ Cubic yards

$\%$ Percent recovery 


\section{Executive Summary}

This Corrective Action Decision Document (CADD) has been prepared for Corrective Action Unit (CAU) 516, Septic Systems and Discharge Points, Nevada Test Site, Nevada, in accordance with the Federal Facility Agreement and Consent Order (1996). Corrective Action Unit 516 is comprised of the following Corrective Action Sites (CASs):

- 03-59-01 - Bldg 3C-36 Septic System

- 03-59-02 - Bldg 3C-45 Septic System

- 06-51-01 - Sump and Piping

- 06-51-02 - Clay Pipe and Debris

- 06-51-03 - Clean Out Box and Piping

- 22-19-04 - Vehicle Decontamination Area

The purpose of this CADD is to identify and provide the rationale for the recommendation of an acceptable corrective action alternative for each CAS within CAU 516. Corrective action investigation activities were performed between July 22 and August 14, 2003, as set forth in the Corrective Action Investigation Plan. Supplemental sampling was conducted in late 2003 and early 2004.

Analytes detected during the corrective action investigation were evaluated against appropriate preliminary action levels (PALs) to identify contaminants of concern for each corrective action site. Results from radiological surveys were compared to unrestricted release criteria identified in the NV/YMP Radiological Control Manual, Revision 4. Assessment of the data generated from investigation activities revealed the following:

- CAS 03-59-01 includes a septic tank, distribution box, leachfield, and associated piping. The septic tank contains contaminated liquid and solid waste. Total petroleum hydrocarbon (TPH)-diesel-range organics (DRO) are present at concentrations of 7,800 (effluent chamber) and 3,600 milligrams/kilograms ( $\mathrm{mg} / \mathrm{kg}$ ) (influent chamber). The other septic system components (i.e., distribution box, leachfield, and associated piping) were not contaminated.

- CAS 03-59-02 includes a septic tank, distribution box, associated piping, leachfield, and two dry wells. The septic tank contains contaminated liquid and solid waste. The solid material in the effluent chamber contains TPH-DRO contamination at a concentration of $7,900 \mathrm{mg} / \mathrm{kg}$. Gross alpha- and gross beta-radiation were detected in the liquid in the effluent chamber at concentrations of $104 \pm 20$ and $193 \pm 34$ picocuries per liter. 
The solid material in the influent chamber contains TPH-DRO contamination at a concentration of $28,000 \mathrm{mg} / \mathrm{kg}$. The chlorinated compounds 1,1-dichloroethene; 1,2-dichloroethane; and trichloroethene were detected in the solids at Resource Conservation and Recovery Act concentrations of 6, 0.96, and 4 milligrams per liter (mg/L), respectively. These results exceed the respective hazardous waste action levels of $0.7,0.5$, and $0.5 \mathrm{mg} / \mathrm{L}$.

Plutonium $(\mathrm{Pu})-239$ was detected in the soil between 5.5 and 6.5 feet (ft) below ground surface (bgs) at leachfield sample location B06. The Pu-239 concentration of $7.3+1.1$ picocuries per gram exceeds the PAL. The other septic system components (i.e., distribution box, dry wells, and piping) were not contaminated.

- CAS 06-51-01 includes an 82-ft long section of pipe that is part of the $275 \mathrm{ft}$ of piping located between Building 660 and the sump. The ends of this section of pipe contain soil/sediment contaminated with TPH-DRO at a concentration of $220 \mathrm{mg} / \mathrm{kg}$, exceeding the TPH action level of 100 parts per million (ppm). The other septic system components (i.e., sump soil and remaining pipe) were not contaminated.

- CAS 06-51-02 included only surface debris; therefore, sampling was not required. The surface debris was surveyed, removed, and appropriately disposed in the Nevada Test Site 10c landfill.

- CAS 06-51-03 includes a clean-out box containing approximately 0.5 cubic yard $\left(\mathrm{yd}^{3}\right)$ of material contaminated with TPH-DRO at a concentration of $180 \mathrm{mg} / \mathrm{kg}$, exceeding the TPH action level of $100 \mathrm{ppm}$.

- No contaminants of concern were identified at CAS 22-19-04.

Based on the evaluation of analytical data from the corrective action investigation; review of future and current operations in Areas 3, 6, and 22 of the Nevada Test Site; and the detailed and comparative analysis of the potential corrective action alternatives, the following corrective actions were recommended for the CAU 516 CASs.

No Further Action is the preferred corrective action for the following CASs:

- CAS 06-51-02, Clay Pipe and Debris - Housekeeping debris was removed during the corrective action investigation; no environmental waste or concerns remain.

- CAS 22-19-04, Vehicle Decontamination Area - No contaminants of concern were identified at this CAS.

Clean Closure is the preferred corrective action for the following CASs: 
- CAS 03-59-01 - Building 3C-36 Septic System - Clean close the CAS by removing and disposing approximately 1,430 gallons (gal) of liquid and solid waste from both the influent and effluent chambers of the septic tank. The material inside the tank will be removed and disposed of appropriately. The septic tank will be removed and disposed of as construction debris. As a best management practice, the distribution box and a $10-\mathrm{ft}$ section of pipe between the septic tank and distribution box will be removed and disposed of as construction debris.

- CAS 03-59-02, Building 3C-45 Septic System - Clean close the area surrounding sample location B06 in the leachfield by removing approximately $35 \mathrm{yd}^{3}$ of Pu-239 contaminated soil. Clean close the septic tank by removing and disposing approximately 714 gal of liquid and solid waste from both the influent and effluent chambers, and removing and disposing of the septic tank. The septic tank will be removed and disposed as construction debris. As a best management practice, the distribution box will be removed and disposed as construction debris, the dry well north of the leachfield will be excavated to a depth of between 12 and $17 \mathrm{ft}$ bgs; the dry well east of the building foundation will be excavated to $10 \mathrm{ft}$ bgs.

- CAS 06-51-01, Sump and Piping - Clean close by removing approximately $82 \mathrm{ft}$ of contaminated piping running between Building 660 and the sump and disposing of the piping as appropriate.

- CAS 06-51-03, Clean Out Box and Piping - Clean close by removing approximately $0.5 \mathrm{yd}^{3}$ of the contaminated solid material from the clean-out box, removing the clean-out box, and disposing appropriately. The associated piping will be removed as a best management practice.

The preferred corrective action alternatives were evaluated on technical merit focusing on performance, reliability, feasibility, and safety. The alternatives were judged to meet all requirements for the technical components evaluated. The alternatives meet all applicable state and federal regulations for closure of the site and will eliminate the contaminated media at CAU 516. 


\subsection{Introduction}

This Corrective Action Decision Document (CADD) has been prepared for Corrective Action Unit (CAU) 516, Septic Systems and Discharge Points, Nevada Test Site (NTS), Nevada, in accordance with the Federal Facility Agreement and Consent Order (FFACO) that was agreed to by the State of Nevada, U.S. Department of Energy (DOE), and the U.S. Department of Defense (FFACO, 1996). The NTS is approximately 65 miles (mi) northwest of Las Vegas, Nevada (Figure 1-1). The Corrective Action Sites (CASs) within CAU 516 are located in Areas 3, 6, and 22 of the NTS, in Nye County, Nevada (Figure 1-2). Corrective Action Unit 516 includes six CASs consisting of two septic systems (e.g., septic tanks, distribution boxes) and leachfields, a sump, a clean-out box, two dry wells, a vehicle decontamination area, associated piping, and housekeeping debris. Corrective Action Unit 516 is comprised of the following CAS:

- 03-59-01 - Bldg 3C-36 Septic System

- 03-59-02 - Bldg 3C-45 Septic System

- 06-51-01 - Sump and Piping

- 06-51-02 - Clay Pipe and Debris

- 06-51-03 - Clean Out Box and Piping

- 22-19-04 - Vehicle Decontamination Area

\subsection{Purpose}

Table 1-1 provides the general location and description of each CAS as included in the FFACO (1996). All the CASs within CAU 516 are described in the Corrective Action Investigation Plan (CAIP) for Corrective Action Unit 516: Septic Systems and Discharge Points, Nevada Test Site, Nevada (NNSA/NSO, 2003).

This CADD develops and evaluates potential corrective action alternatives and provides the rationale for the selection of a recommended corrective action alternative for each CAS within CAU 516. The need for evaluation of corrective action alternatives is based on process knowledge and the results of investigative activities conducted in accordance with the CAIP (NNSA/NSO, 2003). The CAIP provides information relating to the history, planning, and scope of the investigation. The CAIP was prepared by the DOE, National Nuclear Security Administration Nevada Site Office (NNSA/NSO) 


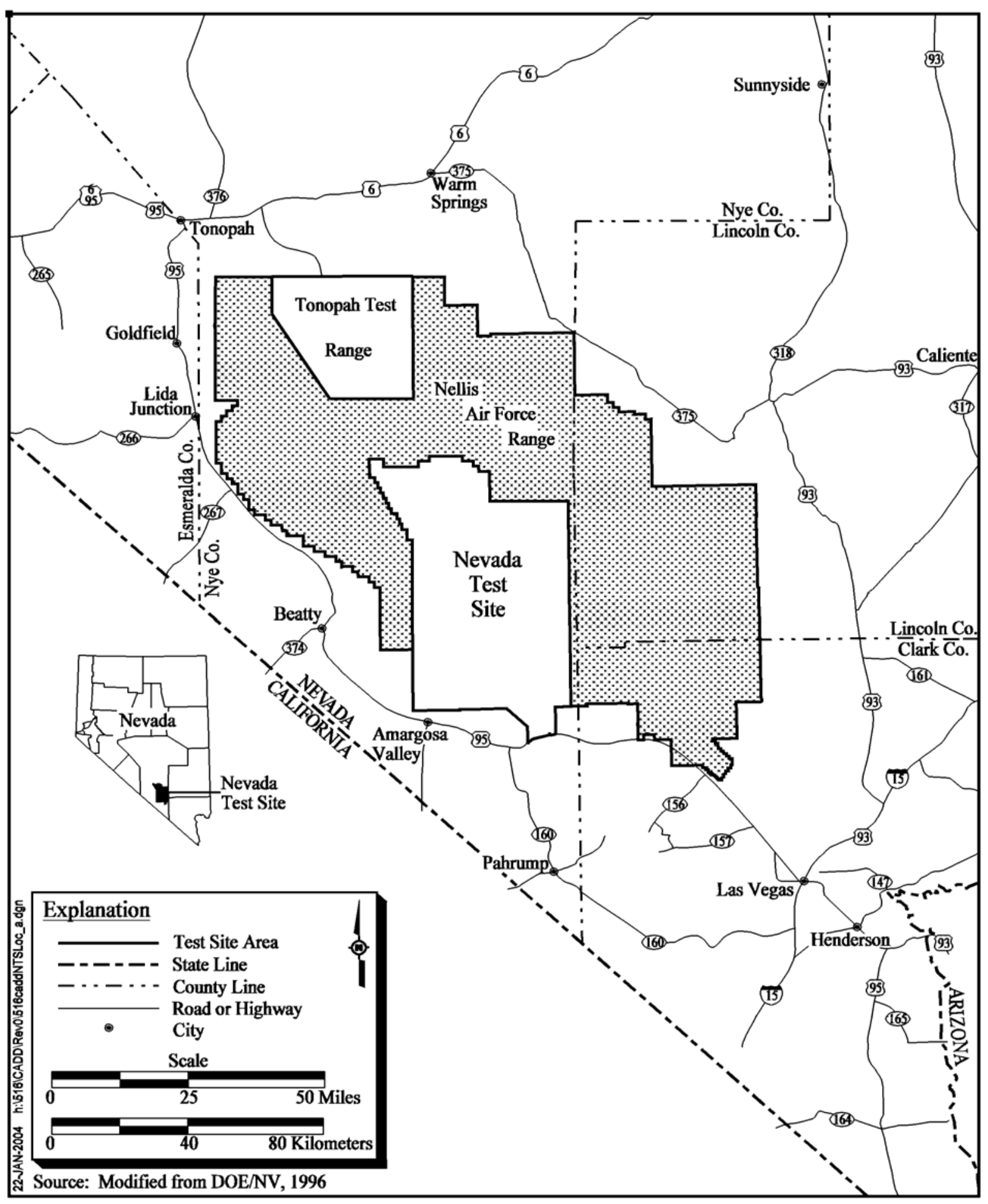

Figure 1-1 


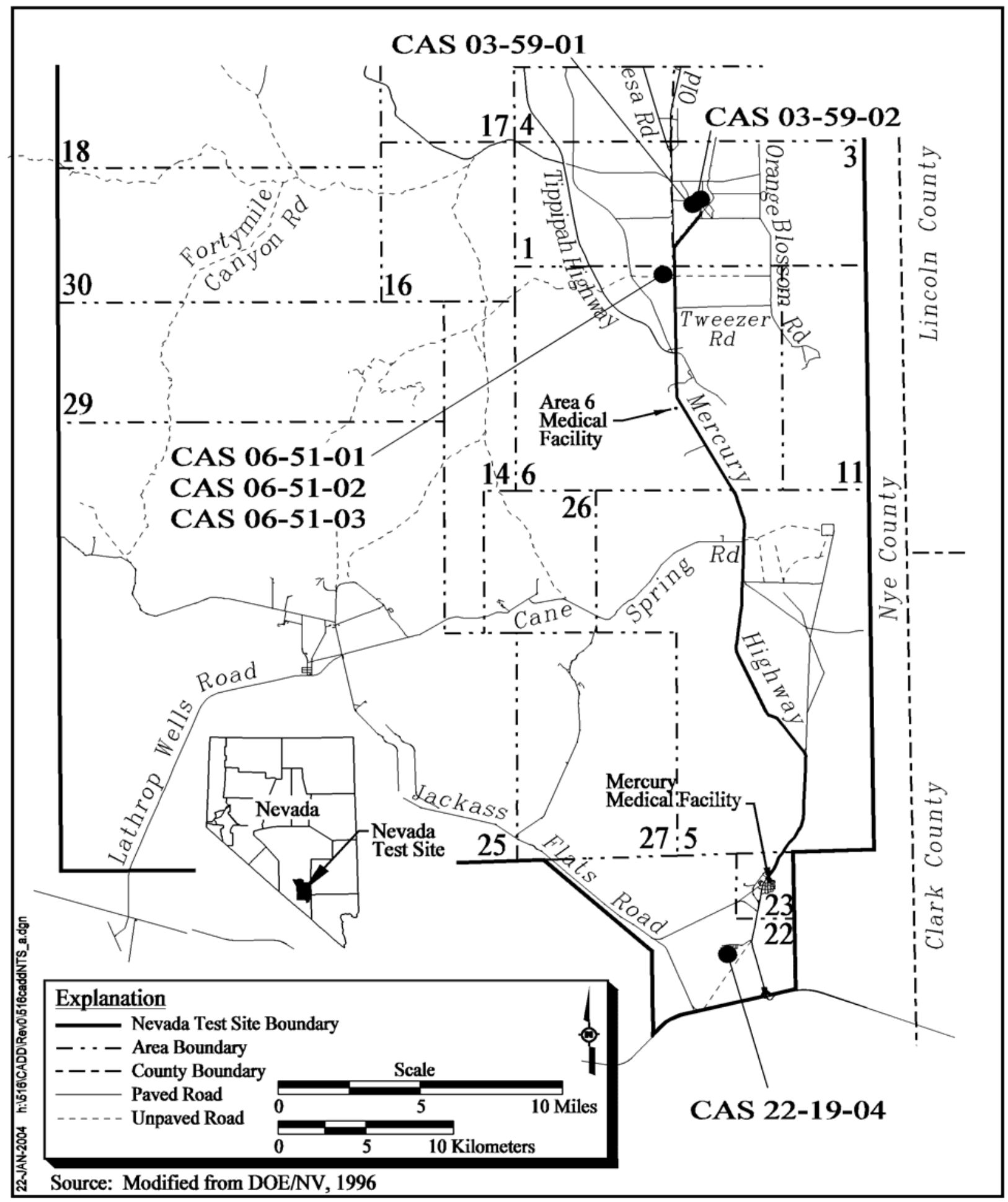

Figure 1-2

CAU 516, Corrective Action Sites Location Map 
Table 1-1

CAU 516 Corrective Action Sites

\begin{tabular}{||l|l|l|l|}
\hline $\begin{array}{c}\text { Nevada Test } \\
\text { Site Area }\end{array}$ & \multicolumn{1}{|c|}{ Corrective Action Site } & \multicolumn{1}{|c|}{ CAS Description ${ }^{\mathrm{a}}$} & \multicolumn{1}{|c|}{ Facility Association $^{{ }^{\mathbf{1}}}$} \\
\hline \hline \multirow{2}{*}{ Area 3 } & $03-59-01$ & Bldg 3C-36 Septic System & Area 3 Camp, Building 3C-36 \\
\cline { 2 - 4 } & $03-59-02$ & Bldg 3C-45 Septic System & Area 3 Camp, Building 3C-45 \\
\hline \multirow{3}{*}{ Area 6 } & $06-51-01$ & Sump and Piping & Well 3 Yard, Building 660 \\
\cline { 2 - 4 } & $06-51-02$ & Clay Pipe and Debris & Well 3 Yard, Building 660 \\
\cline { 2 - 4 } & $06-51-03$ & Clean-Out Box and Piping & Well 3 Yard, Building 660 \\
\hline Area 22 & $22-19-04$ & Vehicle Decontamination Area & Desert Rock Airport \\
\hline
\end{tabular}

${ }^{\mathrm{a} C A S}$ description from the FFACO (1996)

${ }^{\mathrm{b}}$ General location from the FFACO (1996)

and submitted to the Nevada Division of Environmental Protection (NDEP) for approval prior to implementation; therefore, this information will not be repeated in this CADD.

\subsection{Scope}

The scope of the activities used to identify and recommend a preferred corrective action alternative for each CAS within CAU 516 includes the following:

- Evaluation of current site conditions, including the concentration and extent of contaminants of concern (COCs)

- Development of corrective action objectives commensurate with the complexity of each CAS

- Identification of corrective action alternative screening criteria

- Performance of detailed and comparative evaluations of corrective action alternatives in relation to corrective action objectives and screening criteria

\subsection{Corrective Action Decision Document Contents}

This CADD is divided into the following sections and appendices:

Section 1.0 - Introduction: Summarizes the purpose, scope, and contents of this CADD.

Section 2.0 - Corrective Action Investigation Summary: Summarizes the investigation field activities, the results of the investigation, and the need for corrective action. 
Section 3.0 - Evaluation of Alternatives: Describes, identifies, and evaluates the steps taken to determine a preferred corrective action alternative for each CAS.

Section 4.0 - Recommended Alternative: Presents the preferred corrective action alternative for each CAS and the rationale based on the corrective action objectives and screening criteria.

Section 5.0 - References: Provides a list of all referenced documents used in the preparation of this CADD.

Appendix A: Corrective Action Investigation Report for CAU 516: Provides a description of the project objectives, field investigation and sampling activities, investigation results, waste management, and quality assurance. Section A.3.0 through Section A.11.0 provide CAS-specific information regarding field activities, sampling methods, and laboratory analytical results from the investigation sampling.

Appendix B: Data Assessment of Sample Results for CAU 516: Provides an assessment of data obtained during the CAU 516 investigation. The appendix also summarizes and compares the investigation results to the requirements set forth during the data quality objective (DQO) process.

Appendix C: Cost Estimates for CAU 516: Presents cost estimates for the construction, operation, and maintenance of each corrective action alternative evaluated for each CAS.

Appendix D: Sample Location Coordinates for CAU 516: Provides global positioning system (GPS) coordinates for the investigation sample locations.

Appendix E: Project Organization for CAU 516: Identifies the NNSA/NSO Project Manager and other appropriate personnel involved with the CAU 516 characterization and closure activities for each CAS.

Appendix F: NDEP Comments: Contain responses to NDEP comments on the Draft CADD.

To ensure all project objectives, health and safety requirements, and quality control procedures were adhered to, all investigation activities were performed in accordance with the following documents: 
- CAIP for CAU 516: Septic Systems and Discharge Points (NNSA/NSO, 2003)

- Record of Technical Change (ROTC) No. 1 to the CAIP, which documents changes to the preliminary action levels (PALs) agreed to by NDEP and NNSA/NSO. This ROTC specifically discusses the radiological PALs and their application to the findings of the CAU 516 corrective action investigation (CAI).

- Industrial Sites Quality Assurance Project Plan (QAPP) (NNSA/NV, 2002)

- $\quad$ FFACO (1996)

- Project Management Plan (DOE/NV, 1994)

- Approved standard quality practices and detailed operating procedures 


\subsection{Corrective Action Investigation Summary}

The following sections summarize the CAU 516 investigation activities, investigation results, and evaluate closure alternatives for each CAS requiring corrective action. Detailed investigation activities and results for CAU 516 are presented in Appendix A of this document.

\section{$2.1 \quad$ Investigation Activities}

Corrective action investigation activities were performed as set forth in the approved CAU 516 CAIP (NNSA/NSO, 2003) from July 22 through August 14, 2003. Additional sampling was conducted on November 7 and 8, 2003; December 1, 2003; and January 9 and 16, 2004. The primary purpose of the CAU 516 CAI was to:

- Determine if contaminants of potential concern (COPCs) are present within the CAS-specific system components and/or soils associated with the components.

- Determine whether the COPCs, if present, exceed PALs and become COCs.

- Determine the lateral and vertical extent of identified COCs.

- Ensure adequate data have been collected to recommend closure alternative for the sites under the NDEP, Resource Conservations and Recovery Act (RCRA), and DOE requirements.

Sufficient information was obtained to develop and evaluate corrective action alternatives for each CAS located within CAU 516. The CAI for CAU 516 included the following activities that were designed to address the Data Quality Objective (DQO) decision statements in the CAIP:

- Collect environmental samples for laboratory analyses to determine the nature of COPCs at all CASs (except 06-51-02) and determine if they exceed the PALs.

- Collect GPS coordinates at sample locations at each CAS.

- Collect and analyze septic tank content samples at CASs 03-59-01 and 03-59-02 to support waste characterization.

- Field-screen soil samples for volatile organic compounds (VOCs) and alpha and beta/gamma radiation at each CAS, and total petroleum hydrocarbons (TPH) at all CASs except 06-51-02. 
- Collect additional environmental samples from step-out sample locations for laboratory analyses to define the vertical and lateral extent of contamination at CASs where COCs were identified.

- Collect quality control (QC) samples for laboratory analyses to ensure that the data generated from the analysis of investigation samples meet the requirements of the data quality indicators (DQIs).

- Conduct exploratory excavations to inspect discrete portions of the septic system for residual sediment.

- Conduct video mole surveys of septic system piping for sediment and breaches in the piping. Collect and analyze samples of residual sediments from piping, if adequate material is present to characterize the contents. Collect and analyze soil samples below any breaches in the piping.

- Verify and document depth of the dry wells at CAS 03-59-02 to the extent possible.

- Seal (e.g., plug, grout, cap) any septic system piping that could potentially release material into the septic system or directly into the environment.

- Remove surface debris at CAS 06-51-02.

This investigation strategy allowed the nature and extent of contamination associated with each CAS to be established. The following sections describe the specific investigation activities at CAU 516.

\section{Field Screening}

Field screening was conducted on soil samples using the headspace method for VOCs, handheld instrument surveys for alpha and beta/gamma radiation, and on-site gas chromatography for TPH. Field screening was conducted for VOCs using a flame ionization detector, and for alpha and beta/gamma radiation using a handheld radiation survey instrument.

\section{Intrusive Investigation}

Surface and subsurface soil sampling was conducted at all CASs within CAU 516 except 06-51-02. Soil samples were collected using "scoop or trowel" (surface grab samples), backhoe, and sonic drilling techniques. Surface soil samples were collected from 0 to 1 foot ( $\mathrm{ft}$ ) below ground surface (bgs) at biased locations focusing on surface features (e.g., staining, field-screening results [FSRs]). Subsurface soil samples were collected directly beneath subsurface features or the object being investigated (e.g., bottom of septic tanks, piping). The surface and subsurface samples were 
located based on information identified during the DQO process judged to best identify contamination release points or migration pathways.

Samples collected for geotechnical analyses were not analyzed since the results would not impact corrective action decisions; however, the samples were archived in the event future geotechnical analysis is required to complete selected corrective actions.

\section{Waste Characterization}

Characterization of septic system components included visual inspection, photodocumentation, radiological surveys, and direct sampling of septic system contents, if sufficient material was present. Samples were collected from septic tank chambers using a Composite Liquid Waste Sampler (COLIWASA). Waste characterization activities were intended to gather sufficient information about the septic tank contents to support decisions regarding the disposal of materials during future closure activities.

The surfaces of septic tanks, distribution boxes, and associated piping in each CAS were surveyed to identify the presence and extent of radiological contamination for waste characterization purposes and to determine if the feature exceeded the unrestricted release criteria.

Waste characterization samples of liquid and solid media were collected from the septic system components when sufficient material was present. All waste characterization samples were submitted to the laboratory for analysis.

\section{Laboratory Analysis}

Laboratory analysis of soil, liquid, and solid samples provided the means for the quantitative measurement of COPCs.

The analytical program for environmental soil sampling during the investigation followed the CAIP and is summarized in Table 2-1. Additional analyses were performed on solid and liquid samples collected from septic system components (e.g., septic tanks, piping) to support waste characterization. The waste characterization analytical program is summarized in Table 2-2. 
Table 2-1

Environmental Soil Sample Analyses Conducted at CAU 516

\begin{tabular}{|c|c|c|c|c|c|c|c|c|c|}
\hline $\begin{array}{l}\text { Corrective } \\
\text { Action Site }\end{array}$ & \multicolumn{9}{|c|}{ Analyses } \\
\hline CAS 03-59-01 & $\mathrm{X}$ & $\mathrm{X}$ & $\bar{X}$ & $\bar{X}$ & -- & $\bar{X}$ & $\mathrm{X}$ & -- & $\mathrm{X}$ \\
\hline CAS 06-51-01 & $\mathrm{X}$ & $x$ & $x$ & $\mathrm{x}$ & -- & $\mathrm{X}$ & $\mathrm{x}$ & -- & $\mathrm{X}$ \\
\hline CAS 06-51-02 & \multicolumn{9}{|c|}{ No samples were collected. Debris removal only. } \\
\hline CAS 06-51-03 & $\mathrm{x}$ & $\mathrm{X}$ & $\mathrm{X}$ & $\mathrm{x}$ & $\mathrm{X}$ & $\mathrm{X}$ & $\mathrm{X}$ & -- & $\mathrm{X}$ \\
\hline CAS 22-19-04 & $x$ & $x$ & $x$ & $\mathrm{x}$ & -- & $\mathrm{x}$ & $x$ & $x$ & $x$ \\
\hline
\end{tabular}

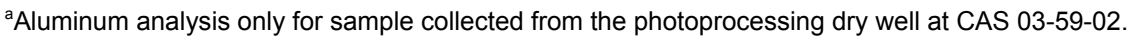

$\mathrm{DRO}=$ Diesel-range organics

$\mathrm{GRO}=$ Gasoline-range organics

$\mathrm{PCB}=$ Polychlorinated biphenyls

RCRA = Resource Conservation and Recovery Act

SVOCs $=$ Semivolatile organic compounds

VOCs $=$ Volatile organic compounds

-- = Not applicable

Table 2-2

Waste Characterization Sample Analyses Conducted at CAU 516

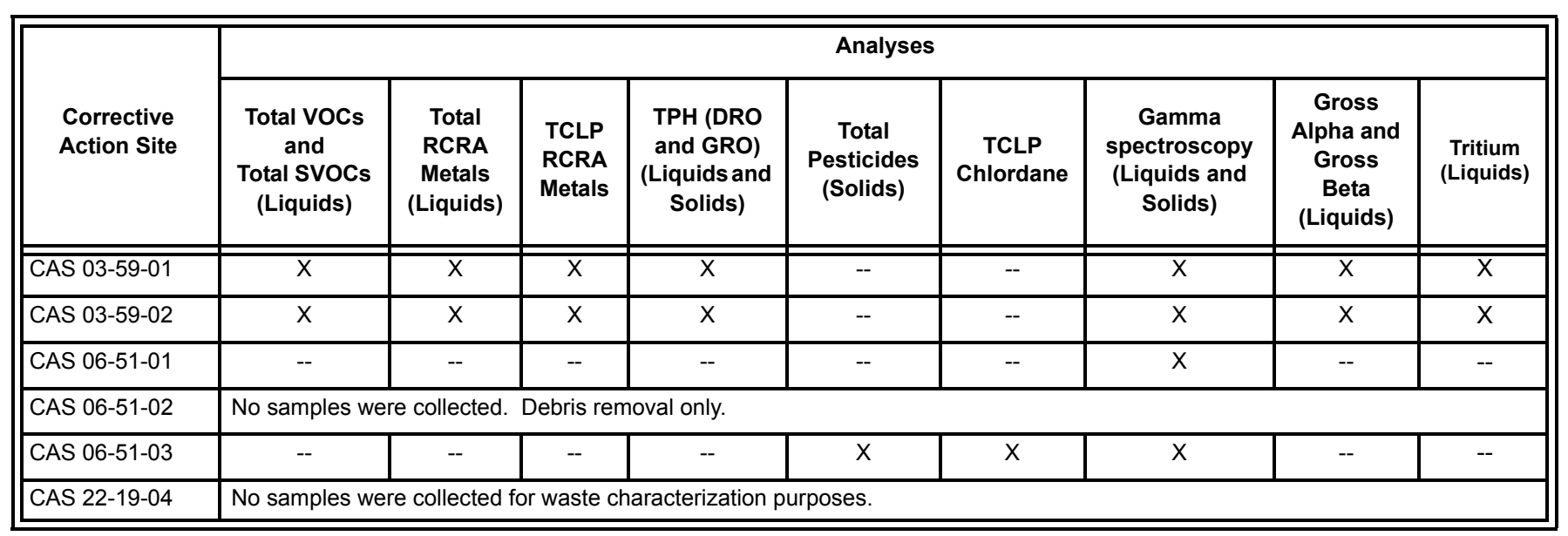

DRO $=$ Diesel-range organics

$\mathrm{GRO}=$ Gasoline-range organics

RCRA = Resource Conservation and Recovery Act

TCLP - Toxicity Characteristic Leaching Procedure
-- = Not applicable

SVOCs $=$ Semivolatile organic compounds

VOCs = Volatile organic compounds

PCBs $=$ Polychlorinated biphenyls 


\section{Conceptual Site Models}

During the DQO process, conceptual site models (CSMs) were developed that represent the release mechanisms, exposure points, and potential migration pathways for each CAS. These are provided in the CAIP. The CSMs identified soil potentially impacted by surface and/or subsurface disposal/release of contaminants. The release mechanisms include both designed (e.g., discharge points) and accidental releases (e.g., tank failure, pipe breach). The two models assumed that the highest concentration of contamination would be concentrated in the soil immediately beneath and adjacent to the release point of the various system components. The extent of underlying soil impacted is expected to be variable and dependent upon the volume of effluent released, physical and chemical properties of the surrounding media, geological conditions, and physical and chemical properties of the COPCs. The system configurations, migration pathways, and release mechanisms identified during the CAI were consistent with the CSMs provided in the CAIP.

Section 2.1.1 through Section 2.1.6 discuss the investigative activities conducted at each of the CAU 516 CASs. Results of the investigation validate the CSMs outlined above and presented in the CAIP for CAU 516 (NNSA/NSO, 2003).

\subsubsection{CAS 03-59-01, Bldg 3C-36 Septic System}

This CAS is located in the former Area 3 Camp south of Road 3-01 and consists of a septic tank, leachfield, distribution box, and septic system piping (Appendix A, Figure A.3-1). The septic tank is located south of Building 3C-36 and has an approximate 3,000 gallon (gal) capacity. The septic tank is constructed of precast concrete and measures 10 by 8 by $5 \mathrm{ft}$. The distribution box is $10 \mathrm{ft}$ south of the septic tank. The leachfield is located approximately $76 \mathrm{ft}$ south of the former Building $3 \mathrm{C}-36$ location. The leachfield is approximately 60 by $30 \mathrm{ft}$ and consists of three lines of perforated 4-inch (in.) pipe. This septic system was connected to Building 3C-36, which contained seven offices, one blueprint room, one secretarial area, and one rest room that included a shower stall, toilet, sink, and floor drain. The LANL Rack Service hole located approximately $30 \mathrm{ft}$ northwest of the septic tank is not part of CAS 03-59-01. No variations from the system configuration presented in the CAIP were identified and the CSM remains valid for this CAS. The following sections summarize the investigative fieldwork conducted at CAS 03-59-01. 


\section{Field Screening}

Soil samples were screened for VOCs, TPH, and alpha and beta/gamma radiation. The FSRs were compared to field-screening levels (FSLs) to guide subsequent sampling decisions and help determine which samples were to be submitted for laboratory analysis. Media from both septic tank chambers were screened for fecal coliform prior to sampling and all the results were negative.

\section{Intrusive Investigation Activities}

The septic tank and distribution box manholes were uncovered by a backhoe, monitored for toxic gases, and visually inspected. The septic tank was found to contain approximately 3,000 gal of sewage. One sample was collected from each of the two chambers of the septic tank to be analyzed for waste characterization parameters. The distribution box contained moisture; however, the volume was insufficient to sample.

The discharge pipe, originating from the clean-out and ending at the outfall of the distribution box were investigated by a video mole survey. The pipe was free of residual material and no breaches were identified.

A total of 26 environmental soil samples (including 2 duplicates) from 17 locations were collected during the investigation activities conducted at CAS 03-59-01. These samples were analyzed for the parameters listed in Table A.3-1 (Appendix A). The sample locations are shown in Figure A.3-1 (Appendix A).

Nine soil samples (including one duplicate) were collected from four locations (A01, A02, A03, and A04) around both the septic tank and the distribution box. Seventeen soil samples (including one duplicate) were collected from 13 sample locations (A05, A06, A06B, and A07 to A16) in and nearby the leachfield (Appendix A, Figure A.3-1).

One sample was collected from beneath the influent and one sample from beneath the effluent pipe of both the septic tank and the distribution box. The sample depths ranged between 3 and $5 \mathrm{ft}$ bgs. One additional sample was taken at each location from 10 to $11 \mathrm{ft}$ bgs

One sample was taken at the interface of the leachrock and native soil from various intervals ranging between 7 and $17 \mathrm{ft}$ bgs below each of the three leachfield lines. The three locations were evenly 
distributed at the distal end, center, and proximal end of the leachfield. The samples were collected with the aid of a backhoe.

\section{Waste Characterization}

Waste characterization activities conducted at CAS 03-59-01 included visual inspection, a video mole survey, a radiological survey, photodocumentation, and sampling of the septic tank. One liquid sample was collected from the influent chamber of the septic tank and another sample was taken from the effluent chamber. The liquid samples were separated into three phases at the laboratory (i.e., liquid, sludge, and sediment) and each phase was assigned a unique sample number and analyzed separately. There was no solid or sludge material in the distribution box and the volume of liquid was insufficient to sample. The piping in the sewer system and the leachfield was inspected with a video mole and found to be free of radiation, and any liquid, sediment, or sludge accumulation.

Investigation activities associated with CAS 03-59-01 are further detailed in Appendix A (Section A.3.2).

\subsubsection{CAS 03-59-02, Bldg 3C-45 Septic System}

This CAS is located north of Road 3-01 and west of Angle Road in Area 3 and consists of a septic tank, leachfield, distribution box, and associated piping that serviced Building 3C-45 (Figure A.4-1). The CAS also includes two dry wells. One dry well is associated with Building 3C-45 known as the Los Alamos National Laboratory (LANL) Yard Dry Well, and the other is used for the disposal of photoprocessing chemicals from the Mobile Photoprocessing Trailers.

The septic tank is located east of Building 3C-45 and has an estimated 1,200-gal capacity. The septic tank is constructed of precast concrete and measures 8 by 4 by $4.5 \mathrm{ft}$. It is estimated that the septic tank contains approximately 714 gal of liquid waste. The leachfield is approximately $77 \mathrm{ft}$ northeast of the Building 3C-45 pad and has dimensions of about 98 by $59 \mathrm{ft}$. The photoprocessing dry well is located about $8 \mathrm{ft}$ northeast of the leachfield and is $4 \mathrm{ft}$ in diameter. The dry well is overlain by about $3.5 \mathrm{ft}$ of fill material and has a total depth of approximately $12 \mathrm{ft}$ (Holmes \& Narver, 1976). The well was filled with 2-in. aggregate and has a volume estimated at 151 cubic feet $\left(\mathrm{ft}^{3}\right)$. The LANL Yard Dry Well is situated about $10 \mathrm{ft}$ west of Building 3C-45 and was drilled on August 24, 1976. The borehole has a 4 -ft diameter to $44 \mathrm{ft}$ bgs and a 6-ft diameter to $15.5 \mathrm{ft}$ bgs. The borehole has no casing 
and was filled with 1.5-in. washed aggregate (Holmes \& Narver, 1976). An engineering drawing shows a 2-in., acid-resistant polypropylene sewer pipe at $2 \mathrm{ft}$ bgs connecting the building to the dry well (Holmes \& Narver, 1985).

No variations from the system configuration presented in the CAIP were identified and the CSM remains valid for this CAS. The following sections summarize the investigative fieldwork conducted at CAS 03-59-02.

\section{Field Screening}

Soil samples were screened for VOCs, TPH, and alpha and beta/gamma radiation. The FSRs were compared to FSLs to guide subsequent sampling decisions and to determine which samples were to be submitted for laboratory analysis. Prior to sampling, media from both septic tank chambers were screened for fecal coliform and all results were negative.

\section{Intrusive Investigation Activities}

The septic tank and distribution box were uncovered by a backhoe, opened, monitor for toxic gases, and visually inspected. There was $3.5 \mathrm{ft}$ of fill material covering the septic tank and $4 \mathrm{ft}$ of fill material above the distribution box. They were both opened, monitored for VOCs, and visually inspected. The septic tank contains approximately $3.5 \mathrm{ft}$ of liquid with suspended sediments. One liquid sample was collected from each of the two chambers of the septic tank and analyzed for waste characterization parameters. There was no liquid, solid, or sludge material in the distribution box.

The pipes to the septic tank (about $40 \mathrm{ft}$ long) and from the septic tank to the distribution box (about $100 \mathrm{ft}$ long) were surveyed with a video mole. The pipes are made of black plastic and no breaks or joint separations were identified in the piping.

A total of 71 environmental soil samples (including 4 duplicates) from 33 locations were collected during investigation activities conducted at CAS 03-59-02. These samples were analyzed for the parameters listed in Appendix A (Table A.4-1). The sample locations are shown in Appendix A Figure A.4-1.

Nineteen soil samples were collected from eight locations (B01, B02, B03, B04, B23, B24, B25, and B26) around the septic tank and the distribution box. Thirty-five soil samples (including 2 duplicates) 
were collected from 18 locations (B05 to B15 and B27 to B83) within and around the leachfields. Nine soil samples including one duplicate were taken from four locations (B16, B17, B18, and B19) in and around the Photoprocessing Dry Well and eight soil samples were taken from three locations (B20, B21, and B22) in and around the LANL Dry Well.

One sample was collected at a depth between 4 and $5 \mathrm{ft}$ bgs below each influent and effluent pipe at the septic tank and distribution box. An additional sample was collected from 9 to $10 \mathrm{ft}$ bgs for the septic tank and from 7 to $8 \mathrm{ft}$ bgs for the distribution box to determine if contamination had migrated from the septic tank and/or distribution box (Appendix A, Figure A.4-1).

A sample was taken at the leachrock and native soil interface from depth ranging between 5.5 and $17 \mathrm{ft}$ bgs below each of the four leachfield distribution lines. The sampling locations were evenly distributed at the distal end, center, and proximal end of the leachfield. The pipe could not be located in the northeast corner of the leachfield; therefore, a sample was not collected at that location. The samples were collected with a backhoe at 1-ft intervals.

One boring was drilled through the Photoprocessing Dry Well with samples collected at 12 to $13 \mathrm{ft}$ bgs and 16 to $17 \mathrm{ft}$ bgs. Based on these borings, the bottom of the dry well was determined to be about $12 \mathrm{ft}$ bgs. Three boreholes were drilled within $15 \mathrm{ft}$ of the dry well and samples were collected from the 12 to $13 \mathrm{ft}$ bgs and 16 to $17 \mathrm{ft}$ bgs intervals.

One boring was drilled through the LANL Dry Well with three samples collected, one at 26 to $27 \mathrm{ft}$ bgs, one at 42 to $43 \mathrm{ft} \mathrm{bgs,} \mathrm{and} \mathrm{one} \mathrm{at} 48$ to $49 \mathrm{ft}$ bgs. The bottom of the dry well was determined to be approximately $42 \mathrm{ft}$ bgs. Two boreholes were drilled surrounding the dry well and sampled from 42 to $43 \mathrm{ft}$ bgs and 48 to $49 \mathrm{ft}$ bgs in one boring, and from 6 to $7 \mathrm{ft} \mathrm{bgs,} 10$ to $11 \mathrm{ft}$ bgs, and 17 to $18 \mathrm{ft}$ bgs in the other boring.

A geotechnical sample was collected from location B19 at a depth of 10 to $11 \mathrm{ft}$ bgs. This sample was not analyzed. It has been archived and will be analyzed if geotechnical information is required during the corrective action. 


\section{Waste Characterization}

Waste characterization activities conducted at CAS 03-59-02 included visual inspection, a video mole survey, a radiological survey, photodocumentation, and sampling of the septic tank. Prior to sampling, media from both septic tank chambers were screened for fecal coliform and all results were negative. One sample of sewage was collected from the chamber on the influent side of the septic tank and another sample was taken from the chamber on the effluent side. The liquid samples were separated into three phases at the laboratory (i.e., liquid, sludge, and sediment) and each phase was assigned a unique sample number and analyzed separately. The distribution box did not contain any sediment/sludge or liquid and samples were not collected. The piping in the sewer system and leachfield were surveyed and inspected with a video mole. The piping was found to be made of black plastic and did not have any cracks or sediment/sludge accumulation. The piping was free of any radiation.

Investigation activities associated with CAS 03-59-02 are further detailed in Appendix A (Section A.4.2).

\subsubsection{CAS 06-51-01, Sump and Piping}

The CAS 06-51-01 is located in the Well 3 Yard in Area 6 and consists of the septic system associated with Building 660 (U.S. Public Health Services cow barn) and the clay pipe leading to the building (Appendix A, Figure A.5-1). Four floor drains and two sink drains within Building 660 were connected into this sewer system. The sump is located $275 \mathrm{ft}$ north of Building 660 and was designed to be 40 by $50 \mathrm{ft}$ and about $10 \mathrm{ft}$ deep surrounded with a 3-strand, barbwire fence (REECo, 1964). The piping runs past the former location of the CAU 330, CAS 06-02-04 underground storage tank (UST). The UST was removed in February 2003 prior to the field investigations of CASs 06-51-01 and 06-51-03. All that remains of Building 660 is the foundation. In addition, the sump has been filled in with soil, probably when the area was abandoned.

No variations from the system configuration presented in the CAIP were identified and the CSM remains valid for this CAS. The following sections summarize the investigative fieldwork conducted at CAS 06-51-01. 


\section{Field Screening}

Soil samples were screened for VOCs, TPH, and alpha and beta/gamma radiation. The FSRs were compared to FSLs to guide subsequent sampling decisions and to determine which samples were to be submitted for laboratory analysis.

\section{Intrusive Investigation Activities}

A total of 14 environmental soil samples (including one duplicate) from 10 locations were collected during investigation activities conducted at CAS 06-51-01. These samples were analyzed for the parameters listed in Appendix A (Table A.5-1). The sample locations are shown in Appendix A (Figure A.5-1).

One surface soil sample was collected in the approximate center of the sump at location C03. Two samples were taken to define the bottom of the sump at location C07 (one sample at 8.5 to $9.5 \mathrm{ft}$ bgs and the other at 11 to $12 \mathrm{ft}$ bgs). Approximately $49 \mathrm{ft}$ of pipe from Building 660 were absent (37 ft at the northernmost section and $12 \mathrm{ft}$ midway between the sump and the building). The breaks in the sewer line and the absence of the 12-ft section of pipe were identified during the video mole survey. Where the pipe was broken and absent to the north (location C02), two samples were collected below the break (one at 8 to $10 \mathrm{ft}$ bgs and the other at 10 to $11 \mathrm{ft} \mathrm{bgs).} \mathrm{A} \mathrm{sample} \mathrm{was} \mathrm{taken} \mathrm{below} \mathrm{each} \mathrm{of} \mathrm{the}$ two breaks in the section of piping assigned to CAS 06-51-03. The 12-ft section of missing pipe occurs in the area where the UST was removed. One sample was taken below the pipe at each of the two locations where the piping was missing.

A sample was collected from the dry sediment found inside the pipe at location D02. Most of the pipe did not have any sediment accumulation, and all of the pipe sediment that was present was dry. To obtain sufficient volume for laboratory analyses, the sediment was collected from two locations and composited. Subsurface soil samples were collected at locations D03 and D04 below the breaks in the piping at 4 to $5 \mathrm{ft}$ bgs. Locations D02, D03, and D04 are all located along the piping between Building 660 and the sump.

Trenches were excavated perpendicular to each side of the sump. When excavating the east and west trenches at locations C04 and C08, respectively, the backhoe uncovered barbwire and metal "T" posts. It is assumed that this barbwire and posts were part of the fencing originally installed around 
the perimeter of the sump. It is believed that the fence had been pushed over into the sump when it was filled in with soil. Samples were collected from each trench location, C01 (on the south edge), C04 (on the east edge), C06 (on the north edge), C05 (on the lowest edge and north of C08), and C08 (on the west edge). The samples were collected in the native soil just outside the sump at a depth determined to be equivalent to the bottom of the sump ( 8 to $11 \mathrm{ft} \mathrm{bgs).}$

\section{Waste Characterization}

Waste characterization activities conducted at CAS 06-51-01 included visual inspection, radiological surveys, photodocumentation, and sampling of pipe sediments. The pipe in the sewer system was inspected with a video mole and was determined to be vitrified clay pipe (VCP). The piping was found free of radiation.

Investigation activities associated with CAS 06-51-01 are further detailed in Appendix A (Section A.5.2).

\subsubsection{CAS 06-51-02, Clay Pipe and Debris}

The CAS 06-51-02 was a housekeeping CAS that consisted of a variety of surficial debris; a 4-in. diameter clay pipe, wood planks, broken concrete slabs, and metal debris. The CAS 06-51-02 lies approximately $225 \mathrm{ft}$ west of the Building 660 foundation, north of the corral, and east of the barbwire fence (Figure A.6-1).

The preliminary assessment determined that the site was comprised of surficial debris. During the DQO process, it was determined that CAS 06-51-02 required only a housekeeping action to remove the debris. Therefore, no further investigation was necessary. No variations from the site configuration presented in the CAIP were identified and the CSM remains valid for this CAS.

\section{Field Screening}

All debris was screened for alpha and beta/gamma radiation before removing it from the site for disposal. The FSRs were compared to the unrestricted release criteria (DOE/NV, 2000) to determine if the material was within requirements for disposal. 


\section{Intrusive Investigation Activities}

There were no intrusive activities for this CAS. All the debris was on the surface and did not require any disturbance of the surface soils. The location of the debris is shown in Appendix A (Figure A.6-1).

\section{Waste Characterization}

Waste characterization activities conducted at CAS 06-51-02 included visual inspection, photodocumentation, and radiological screening.

\subsubsection{CAS 06-51-03, Clean Out Box and Piping}

The CAS 06-51-03 is part of the sewer system for Building 660. The building has been removed and only the foundation remains. CAS 06-51-03 consists of only the clean-out box on the north side of the building and piping coming into the clean-out box from the west (Appendix A, Figure A.5-1). Clay pipe also connects the clean-out box to the floor drains in Building 660. The sump and piping to the north of the clean-out box are assigned to CAS 06-51-01. The clean-out box is a 3-in. thick, 2- by 2- by 2-ft concrete box (the bottom of the clean-out box is also made of concrete and a steel plate fits over the top). There is a 4-in. VCP that extends into the box from the west. This clay pipe has been sealed with a compression-type plug. Another 4-in. clay pipe enters the bottom of the box from the building and exits to the north, extending $275 \mathrm{ft}$ to the sump (CAS 06-51-01).

No variations from the system configuration presented in the CAIP were identified and the CSM remains valid for this CAS. The following sections summarize the investigative fieldwork conducted at CAS 06-51-03.

\section{Field Screening}

Soil samples were screened for VOCs, TPH, and alpha and beta/gamma radiation. The FSRs were compared to FSLs to guide subsequent sampling decisions and to determine which samples were to be submitted for laboratory analysis.

\section{Intrusive Investigation Activities}

A total of nine environmental soil samples (including one duplicate) from eight locations were collected during investigation activities conducted at CAS 06-51-03. These samples were analyzed 
for the parameters listed in Appendix A (Table A.7-1). The sample locations are shown in Appendix A (Figure A.5-1).

One surface sample was taken from the material within the clean-out box at location D06. The box contained several inches of soil with some dead vegetation on the surface. One subsurface soil sample was taken from 2 to $3 \mathrm{ft}$ bgs below the effluent pipe at location D05, and another sample was taken from 2.4 to $2.7 \mathrm{ft}$ bgs directly below the box to determine the integrity of the box (location D01). Two samples were also collected from 0 to $0.5 \mathrm{ft}$ bgs at location D09, and from 2.4 to $2.7 \mathrm{ft}$ bgs at location D10. Most of the pipe did not have any sediment accumulation and all of the pipe and sediment were dry when inspected with the video mole. Samples were also collected from 1.0 to $1.8 \mathrm{ft}$ bgs (at locations D07 and D08) under the pipe leading into the clean-out box from the west and at the break in the pipe where it reaches the ground surface at locations D11 and D12.

\section{Waste Characterization}

Waste characterization activities conducted at CAS 06-51-03 included visual inspection, radiological surveys, photodocumentation, and sampling of the clean-out box contents. The piping was found free of radiation.

Samples were collected for waste characterization of the soil in the clean-out box and around the piping.

Investigation activities associated with CAS 06-51-03 are further detailed in Appendix A (Section A.7.2).

\subsubsection{CAS 22-19-04, Vehicle Decontamination Area}

The CAS 22-19-04 is a former vehicle decontamination area located approximately $800 \mathrm{ft}$ southwest of the Weather Station in Area 22 (see Figure A.8-1). The vehicle decontamination site consists of a decontamination pad, a drainage trench, and a sump. The decontamination pad or rock-lined washdown area consists of a rectangular depression measuring $32 \mathrm{ft}$ long and $15 \mathrm{ft}$ wide, with a bed of rock ranging from approximately 5 to $10 \mathrm{in}$. in diameter. The drainage trench measures $30 \mathrm{ft}$ long, $3 \mathrm{ft}$ wide, and $2 \mathrm{ft}$ deep and runs between the decontamination pad and sump. The sump consists of an oval-shaped depression in the soil measuring $11 \mathrm{ft}$ long, $9 \mathrm{ft}$ wide, and $4 \mathrm{ft}$ deep. No variations 
from the system configuration presented in the CAIP were identified and the CSM remains valid for this CAS. The following sections summarize the investigative fieldwork conducted at CAS 22-19-04.

\section{Field Screening}

Soil samples were screened for VOCs, TPH, and alpha and beta/gamma radiation. The FSRs were compared to FSLs to guide subsequent sampling decisions.

\section{Intrusive Investigation Activities}

A total of six environmental soil samples (including one duplicate) from five locations (E01 [base of sump]; E03 [center of trench]; and E04, E05, and E06 [washdown pad]) were collected from 0 to $1.0 \mathrm{ft}$ bgs during investigation activities conducted at CAS 22-19-04. These samples were analyzed for the parameters listed in Appendix A (Table A.8-1). The sample locations are shown in Appendix A (Figure A.8-1).

One geotechnical sample was collected at the sump location of CAS 22-19-04. This sample was not analyzed. It has been archived and will be analyzed if geotechnical information is required during the corrective action.

\section{Waste Characterization}

Waste characterization activities conducted at CAS 22-19-04 included visual inspection and photodocumentation.

Investigation activities associated with CAS 22-19-04 are further detailed in Appendix A (Section A.8.2).

\subsection{Results}

A summary of characterization data from the CAI is provided in Section 2.2.1. This information illustrates the degree of characterization accomplished through the field effort and identifies those COCs that exceeded PALs for soil and regulatory disposal levels for waste characterization samples. Section 2.2.2 summarizes the data assessment presented in Appendix B, which demonstrates the correlation between the investigation results and the DQOs. 


\subsubsection{Summary of Characterization Data}

Chemical and radiological results for characterizing sample concentrations exceeding PALs in each of the CASs are presented in Section 2.2.1.1 through Section 2.2.1.6. The PALs for the CAU 516 investigation were identified and agreed to during the DQO process. For chemical COPCs, PALs are taken from the U.S. Environmental Protection Agency (EPA) Region 9 Industrial Preliminary Remediation Goals (PRGs) (EPA, 2002). The PAL for TPH is based on Nevada Administrative Code (NAC) 445A.2272 which states a level of 100 milligrams per kilogram (mg/kg) (NAC, 2003). The ROTC No. 1 to the CAIP was completed to document agreements between NDEP and NNSA/NSO regarding the reference source and values for radiological PALs and the application of those PALs to the findings of CAU 516 corrective action investigation.

Background concentrations for metals were used instead of PRGs when the natural background concentration exceeds the PRG, as is often the case with arsenic. Background is considered the mean plus two times the standard deviation for sediment samples collected by the Nevada Bureau of Mines and Geology throughout the Nevada Test and Training Range (formerly the Nellis Air Force Range) (NBMG, 1998; Moore, 1999).

Radionuclide concentrations measured in CAU 516 environmental samples were compared to dose-based, isotope-specific PALs. The PALs for radiological contaminants are taken from the National Council on Radiation Protection and Measurement (NCRP) Report No. 129, Recommended Screening Limits For Construction, Commercial, Industrial Land Use Scenario (NCRP, 1999), scaled from a 25-to 15-millirem (mrem) per year dose and the generic guidelines for residual concentration of radionuclides in DOE Order 5400.5 (DOE, 1993).

Samples were collected from the contents of the septic tanks at CAS 03-59-01 and CAS 03-59-02, the contents of the clean-out box at CAS 06-51-03, and the soil/sediment from the 82-ft long section of pipe at CAS 06-51-03. These samples were analyzed to support disposal decisions. Based on the analytical results, the liquid will be solidified and disposed as industrial waste and the solid disposed of as hydrocarbon waste.

The corrective action investigation analytical results (organized by CAS) are summarized in the following sections. 


\subsubsection{CAS 03-59-01, BIdg 3C-36 Septic System}

No COCs were identified in the soil surrounding or underneath the septic tank, leachfield, and associated piping. Data was obtained from the following locations: 2 samples from underneath the piping just outside the septic tank, 2 samples from underneath the piping just outside the distribution box, and 10 samples underneath the leachfield piping. Analytical results from all these locations indicate that there were no COCs present at concentrations above the PALs.

Two waste characterization samples were collected from the contents within the septic tank. The concentration of TPH-DRO in sample 516A501S (solid) collected from the effluent chamber is $7,800 \mathrm{mg} / \mathrm{kg}$ and sample 516A502S (solid) collected from the influent chamber had a TPH-DRO concentration of $3,600 \mathrm{mg} / \mathrm{kg}$.

Analytical results associated with this CAS are further detailed in Section A.3.3.

\subsubsection{CAS 03-59-02, BIdg 3C-45 Septic System}

Data was obtained from 2 samples from the soil influent and effluent ends of the septic tank, 2 samples from the soil horizon underneath the piping adjacent to the septic tank, 3 soil samples at step-out locations adjacent to the septic tank, 1 sample from the soil horizon beneath the distribution box, 1 sample from beneath the distribution box effluent piping, 13 samples collected in the leachfield (at the leachrock and native soil interface), 3 samples collected at step-out locations in or near the leachfield, and 3 samples collected at each of the dry wells. Only one soil sample (location B06 from with the leachfield) had a plutonium ( $\mathrm{Pu}$ )-239 concentration exceeding PALs. With the exception of location B06, locations have analytical results less than the PALs. The Pu-239 contamination at location B06 (7.3 \pm 1.1 picocuries per gram $[\mathrm{pCi} / \mathrm{g}])$ is bound by $\mathrm{Pu}-239$ analytical results less than the PAL vertically and horizontally.

A total of six waste characterization samples were collected from within the septic tank. The concentration of TPH-DRO in samples 516B501S (solid material from effluent chamber) and 516B502S (solid materials from the influent chamber) are 7,900 mg/kg and $28,000 \mathrm{mg} / \mathrm{kg}$, respectively. The concentrations of 1,1-dichloroethene (6 mg/L); 1,2-dichloroethane ( $0.96 \mathrm{mg} / \mathrm{L})$; and trichlorethene $(4 \mathrm{mg} / \mathrm{L}$ ) present in sample 516B506 (solid material in influent chamber) exceeds the RCRA toxicity characteristic leaching procedure (TCLP) disposal criteria of $0.7 \mathrm{mg} / \mathrm{L}, 0.5 \mathrm{mg} / \mathrm{L}$, 
and $0.5 \mathrm{mg} / \mathrm{L}$, respectively. The concentration of gross alpha (104 picocuries per liter $[\mathrm{pCi} / \mathrm{L}])$ and gross beta (193 pCi/L) present in sample 516B503 (liquid in effluent chamber) exceeds the Nevada Drinking Water Standards (NDWS) of 15.0 and 50 pCi/L, respectively.

Analytical results associated with CAS are further detailed in Section A.3.4.

\subsubsection{CAS 06-51-01, Sump and Piping}

There were no COCs identified in the soil at this CAS; however, TPH-DRO was detected in a section of septic system piping. Fifteen samples (including 1 duplicate) were collected at 11 locations at this CAS. Ten samples were collected at seven locations in and around the sump. No COCs were detected. Five samples were collected between 4 and $11 \mathrm{ft}$ bgs at 4 locations along the septic system piping connecting Building 660 to the sump. The pipe was discontinuous to the north with a section of about $37 \mathrm{ft}$ missing between the sump and piping to the south. No COCs were detected in the soil; however, the composite sample of sediment from inside the clay pipe had concentrations of TPH-DRO of $220 \mathrm{mg} / \mathrm{kg}$. No COCs were identified in the soil underneath any of the breaks in the clay pipe. There is no migration of contaminants outside of the sump or piping. No other COCs were detected in soil samples collected from CAS 06-51-01.

Analytical results associated with CAS 06-51-01 are further detailed in Appendix A (Section A.5.0).

\subsubsection{CAS 06-51-02, Clay Pipe and Debris}

There were no samples collected at this CAS. This CAS was a "housekeeping" site which only required that the surface debris be removed and disposed of appropriately. The debris was surveyed prior to removal to support the decision to dispose the debris in the NTS 10c Landfill.

\subsubsection{CAS 06-51-03, Clean Out Box and Piping}

Total petroleum hydrocarbons-DRO were found in the sample collected from soil/sediment within the clean-out box at a concentration of $180 \mathrm{mg} / \mathrm{kg}$. Samples were also taken adjacent to the box and included soil beneath the pipe on the effluent side and soil beneath the box. These samples did not have concentrations of COPCs above the PALs. These results indicate that the TPH-DRO has not 
migrated outside the clean-out box or from the piping. No other COCs were detected in soil samples collected from CAS 06-51-03.

Analytical results associated with CAS 06-51-03 are further detailed in Section A.7.0.

\subsubsection{CAS 22-19-04, Vehicle Decontamination Area}

Three soil samples were taken of the soil beneath the rock-lined pad, one sample of the soil in the lowest point of the sump, and one sample of the soil in the trench halfway between the sump and the rock-lined bed. Samples were analyzed for the parameters shown in Table A.8-1. There were no COCs identified in the samples at this CAS.

Analytical results associated with CAS 22-19-04 are further detailed in Appendix A (Section A.8.0).

\subsubsection{Data Assessment Summary}

An assessment of CAU 516 investigation results determined that the data collected met the DQIs of precision, accuracy, representativeness, comparability, and completeness (PARCC) and supports their intended use in the decision-making process. In addition, the sensitivity was evaluated and further supported the use of the data. The assessment provided in Appendix B includes an evaluation of the DQIs to determine the degree of acceptability and usability of the reported data in the decision-making process. Additionally, a reconciliation of the data with the CSMs established for this project was conducted. The analytical results for CAU 516 supported the CSMs and DQO established for each CAS. Conclusions were based on the results of the quality control measurements and are discussed in Appendix A (Section A.10.0) and Appendix B.

\subsection{Need for Corrective Action}

The need for corrective action was determined by comparing the analytical results for the soil samples to radiological and nonradiological PALs. If the concentration of these analytes exceeded the PALs, corrective actions were evaluated. These CAS-specific COCs are discussed in the following subsections. 
The identification of system components exceeding unrestricted release criteria (e.g., COCs above PALs in surface and subsurface soil require corrective action alternatives to be considered and evaluated. The impacted volume/characteristics and site-specific constraints are provided in each CAS-specific subsection. The corrective action alternatives are identified in Section 3.0 and evaluated for their ability to ensure protection of the human health and the environment in accordance with NAC 445A (NAC, 2003), feasibility, and cost effectiveness.

\subsubsection{CAS 03-59-01, Bldg 3C-36 Septic System}

Contaminants of concern were not detected in the soil surrounding the septic tank, the distribution box, or the leachfield lines. Total Petroleum hydrocarbon-DRO was detected within the septic tank at levels requiring disposal as a hydrocarbon waste. The capacity of the septic tank waste is approximately 3,000 gal.

There were no site-specific characteristics that would constrain remediation at this CAS.

\subsubsection{CAS 03-59-02, BIdg 3C-45 Septic System}

Contaminants of concern were not detected above PALs in the soil surrounding the septic tank and distribution box, or in the two dry wells. Plutonium-239 was detected in sample 516B011 at a concentration of $7.3 \pm 1.1 \mathrm{pCi} / \mathrm{g}$ between 5.5 and $6.5 \mathrm{ft}$ bgs at sample location B06. When conservatively considering the uncertainty, a value of $8.4 \mathrm{pCi} / \mathrm{g}$ (calculated by adding the reported concentration of $7.3 \mathrm{pCi} / \mathrm{g}$ to and the uncertainty of $1.1 \mathrm{pCi} / \mathrm{g}$ ) is obtained, which only slightly exceeds the PAL for Pu-239 (7.62 pCi/g). The contamination is limited vertically between 5.5 and $6.5 \mathrm{ft}$ bgs. The radiological FSR for the sample collected did not indicate the presence of any radionuclides exceeding FSLs. A duplicate sample analyzed from the same interval did not contain $\mathrm{Pu}-239$ at concentrations that were equal to or greater than the PAL. In addition, sample 516B013 collected from 8.5 to $9.5 \mathrm{ft}$ bgs at location B06 did not contain $\mathrm{Pu}-239$ at a concentration equal to or greater than the minimum detectable concentration (MDC). Based on the limited vertical extent, relatively low concentrations, and a duplicate analysis, the $\mathrm{Pu}-239$ is considered to be limited in extent both laterally and vertically. Step-out sampling and analysis demonstrated that the contamination at sample location B06 is limited to a small area. This suggests that only a very small amount (i.e., a flake) of $\mathrm{Pu}-239$ is present. 
Remediation of the $\mathrm{Pu}-239$ contamination at location B06 by excavation would require the removal of approximately 35 cubic yards $\left(\mathrm{yd}^{3}\right)$ of soil. The $\mathrm{Pu}-239$ contamination is not physically contained at location B06; however, an evaluation of the NAC 445A.227 (2) (a-k) criteria supports the protection of groundwater and the prevention of inadvertent contact with $\mathrm{Pu}-239$ by possible receptors at this CAS. Step-out sample results suggest that the extent of contamination would not exceed $10 \mathrm{ft}$ in any direction.

Total Petroleum Hydrocarbon-DRO was detected in the 545 gal of liquid and solids in the effluent chamber of the septic tank at a concentration of 7,900 mg/kg. Gross alpha and gross beta concentrations detected in the liquid in the effluent chamber exceed the NDWS (DOE, 1993) disposal criteria; therefore, the liquid must be solidified to be disposed of properly.

The TPH-DRO was detected in the influent chamber of the septic tank at a concentration of $28,000 \mathrm{mg} / \mathrm{kg}$. The chlorinated compounds 1,1-dichloroethene; 1,2-dichloroethane; and trichloroethene were detected in the influent chamber at concentrations exceeding RCRA TCLP action levels for hazardous waste.

There were no site-specific characteristics that would constrain remediation at this CAS.

\subsubsection{CAS 06-51-01, Sump and Piping}

Total petroleum hydrocarbons-DRO were detected in a sample collected from the compositing of sediments collected from both ends of the 82-ft section of piping. The concentration of TPH-DRO is $220 \mathrm{mg} / \mathrm{kg}$. The volume of contaminated sediment and the $82-\mathrm{ft}$ section piping is estimated to be $7 \mathrm{ft}^{3}$.

There were no site-specific characteristics that would constrain remediation at this CAS.

\subsubsection{CAS 06-51-02, Clay Pipe and Debris}

No samples were taken at this CAS, as it is a "housekeeping" CAS. The clay pipe and debris were removed from the surface and disposed at the NTS 10c Landfill. No further action is required at this CAS. 


\subsubsection{CAS 06-51-03, Clean Out Box and Piping}

Total petroleum hydrocarbons-DRO was present in the soil/sediment of the clean-out box at a concentration of $180 \mathrm{mg} / \mathrm{kg}$, which exceeds the action level of 100 parts per million (ppm) (NAC, 2003). The volume of the contaminated contents of the clean-out box is estimate to be approximately $0.5 \mathrm{yd}^{3}$. The clean-out box is not covered; therefore, the contamination is not contained. There was no contamination detected in the soil outside the clean-out box or piping.

There were no site-specific characteristics that would constrain remediation at this CAS.

\subsubsection{CAS 22-19-04, Vehicle Decontamination Area}

Contaminants of concern were not detected at this site. 


\subsection{Evaluation of Alternatives}

The purpose of this section is to present the corrective action objectives, describe the standards and decision factors used to screen the various corrective action alternatives, conduct a risk-based analysis, and develop and evaluate the corrective action alternatives that will meet the corrective action objectives for each CAS within CAU 516.

\subsection{Corrective Action Objectives}

The corrective action objectives are media-specific goals for protecting human health and the environment. Based on the potential exposure pathways, the following corrective action objectives have been identified for CAU 516:

- Prevent or mitigate exposure to media containing COCs at concentrations exceeding PALs as defined in the CAIP (NNSA/NV, 2003).

- Prevent the spread of COCs beyond each CAS.

- Close septic tanks in accordance with State of Nevada regulations (NAC, 2002)

- Protection of human health and the environment based on a risk-based analysis.

\subsection{Screening Criteria}

The screening criteria used to evaluate and select the preferred corrective action alternatives are identified in the EPA Guidance on RCRA Corrective Action Decision Documents (EPA, 1991) and the Final RCRA Corrective Action Plan (EPA, 1994).

Corrective action alternatives are evaluated based on four general corrective action standards and five remedy selection decision factors. All corrective action alternatives must meet the general standards to be selected for evaluation using the remedy selection decision factors.

The general corrective action standards are as follows:

- Protection of human health and the environment

- Comply with media cleanup standards

- Control the source(s) of the release 
- Compliance with applicable federal, state, and local standards for waste management and closure of septic tanks

The remedy selection decision factors are as follows:

- Short-term reliability and effectiveness

- Reduction of toxicity, mobility, and/or volume

- Long-term reliability and effectiveness

- Feasibility

- Cost

As identified in the CAIP, the future use for the CAU is to be industrial, which is similar to the current use (DOE/NV, 1998). The Area 3 CASs (i.e., 03-59-01 and 03-59-02) are within a restricted use zone classified as a "Nuclear and High Explosives Test Zone," which is designated within the Nuclear Test Zone for additional underground and outdoor high-explosive tests or experiments. The zone includes compatible defense and nondefense research, development, and testing projects and activities (DOE/NV, 1996).

The Area 6 CASs (i.e., 06-51-01, 06-51-02, and 06-51-03) are within a restricted use zone classified as a "Defense Industrial Zone," which is designated for stockpile management of weapons, including production, assembly, disassembly or modification, staging, repair, retrofit, and surveillance. Also included in this zone are permanent facilities for stockpile stewardship operations involving equipment and activities such as radiography, lasers, materials processing, and pulsed power (DOE/NV, 1996).

The Area 22 CAS (22-19-04) is within the "Solar Enterprise Zone," which is designated for the development of a solar energy power-generation facility, and light industrial equipment manufacturing, and commercial manufacturing capability (DOE/NV, 1996).

The CSMs developed as part of the DQO process identified the potential release mechanism and exposure pathways by disturbance (excavation) of contaminated media. Potential contact with contaminated tank media by industrial or construction workers must also be considered. This implies a potential exposure route for future industrial workers through ingestion of, inhalation of, and/or dermal contact (absorption) with contaminated media. 
The average depth to groundwater is based on the water table depth measured in water wells closest to the CASs. The groundwater depths are approximately $754 \mathrm{ft}$ bgs for Area 3 (Geomedia, 2002); 1,531 ft bgs for Area 6 (USGS, 2002); and $787 \mathrm{ft} \mathrm{bgs}$ for Area 22 (DRI, 1996). These factors, along with others presented in Section 3.3, support the determination that contaminant migration to groundwater is not considered to be a significant migration or exposure pathway.

\subsubsection{Corrective Action Standards}

The following text describes the corrective action standards used to evaluate the corrective action alternatives.

\section{Protection of Human Health and Environment}

Protection of human health and the environment is a general mandate of the RCRA statute (EPA, 1994). This mandate requires that the corrective action include any necessary protective measures. These measures may or may not be directly related to media cleanup, source control, or management of wastes. The corrective action alternatives are evaluated for the ability to meet corrective action objectives as defined in Section 3.1.

\section{Comply with Media Cleanup Standards}

Each corrective action alternative must evaluate the proposed media cleanup standards as set forth in applicable state and federal regulations, and as specified in the CAIP (NNSA/NSO, 2003). The EPA Region 9 PRGs (EPA, 2002), which are derived from the Integrated Risk Information System, are the basis for establishing the PALs for CAU 516, for organic and inorganic chemical contaminants under NAC 445A.2272 (NAC, 2003). The action level for hydrocarbon impacted soil as established by NAC 445A.2272 is 100 ppm (NAC, 2003). The PALs for radiological contaminants are from the NCRP's Recommended Screening Limits for Construction, Commercial, Industrial Land Use Scenario (1999), scaled from the 25-mrem/year to a 15-mrem/yr dose, and the generic guidelines for residual concentrations of radionuclides in DOE Order 5400.5 (DOE, 1993). Laboratory results above PALs indicate the presence of COCs at levels that may require corrective action.

\section{Control the Source(s) of the Release}

An objective of a corrective action remedy is to stop further environmental degradation by controlling or eliminating additional releases that may pose a threat to human health and the environment. 
Unless source control measures are taken, efforts to clean up releases may be ineffective or, at best, will essentially involve a perpetual cleanup. Therefore, each corrective action alternative must use an effective source control program to ensure the long-term effectiveness and protectiveness of the corrective action.

\section{Comply with Applicable Federal, State, and Local Standards for Waste Management}

During corrective action implementation, waste will be managed based on all applicable regulations, field observations, process knowledge, characterization data, and data collected and analyzed during corrective action implementation. Closure activities at CAS 03-59-01 and CAS 03-59-02 will include disposal of septic tank contents as waste. All waste generated will be managed in accordance with the most strict regulatory driver, including but limited to the following use: Federal, State, DOE orders, waste acceptance criteria (BN, 1995; CFR, 2003; NAC, 2002; NAC, 2003; NRS, 1998; NDEP, 1997a and b). Administrative controls (e.g., hazardous substance control, decontamination procedures, and corrective action strategies) will minimize waste generated during site corrective action activities.

\subsubsection{Remedy Selection Decision Factors}

The following paragraphs describe the remedy selection decision factors used to evaluate the corrective action alternatives.

\section{Short-Term Reliability and Effectiveness}

Each corrective action alternative must be evaluated with respect to its effects on human health and the environment during implementation of the corrective action. The following factors will be addressed for each alternative:

- Protection of the community from potential risks associated with implementation (such as fugitive dusts, transportation of hazardous materials, and explosion)

- Protection of workers during implementation

- Environmental impacts that may result from implementation

- The amount of time until the corrective action objectives are achieved 


\section{Reduction of Toxicity, Mobility, and/or Volume}

Each corrective action alternative must be evaluated for its ability to reduce the toxicity, mobility, and/or volume of the contaminated media. Reduction in toxicity, mobility, and/or volume refers to changes in one or more characteristics of the contaminated media by the use of corrective measures that decrease the inherent threats associated with that media.

\section{Long-Term Reliability and Effectiveness}

Each corrective action alternative must be evaluated in terms of risk remaining at the CAU after the corrective action alternative has been implemented. The primary focus of this evaluation is on the extent and effectiveness of the control that may be required to manage the risk posed by treatment residuals and/or untreated wastes.

\section{Feasibility}

The feasibility criterion addresses the technical and administrative feasibility of implementing a corrective action alternative and the availability of services and materials needed during implementation. Each corrective action alternative must be evaluated for the following criteria:

- Construction and Operation. Refers to the feasibility of implementing a corrective action alternative given the existing set of waste and site-specific conditions.

- Administrative Feasibility. Refers to the administrative activities needed to implement the corrective action alternative (e.g., permits, public acceptance, rights of way, off-site approval).

- Availability of Services and Materials. Refers to the availability of adequate off-site and on-site treatment, storage capacity, disposal services, necessary technical services and materials, and prospective technologies for each corrective action alternative.

\section{Cost}

Costs for each alternative are estimated for comparison purposes only. The cost estimate for each corrective action alternative includes both capital and operation and maintenance costs, as applicable. The following is a brief description of each component:

- Capital Costs. These costs include both direct and indirect costs. Direct costs may consist of materials, labor, mobilization, demobilization, site preparation, construction materials, equipment purchase and rental, sampling and analysis, waste disposal, and health and safety 
measures. Indirect costs include such items as engineering design, permits and/or fees, start-up costs, and any contingency allowances.

- Operation and Maintenance. These costs include labor, training, sampling and analysis, maintenance materials, utilities, and health and safety measures.

Cost estimates for the corrective action alternatives are provided in Appendix C.

\subsection{Development of Corrective Action Alternatives}

This section identifies and briefly describes the viable corrective action alternatives considered for the affected media at the various CASs within CAU 516. Based on the review of existing data, future use, and current operations at the NTS, the following alternatives have been developed for consideration at CAU 516:

- Alternative 1 - No Further Action

- Alternative 2 - Clean Closure

- Alternative 3 - Closure in Place with Administrative Controls

Table 3-1 summarizes the corrective action alternatives evaluated with regard to the components comprising each CAS within CAU 516.

Table 3-1

Corrective Action Alternatives

\begin{tabular}{|c|c|c|c|}
\hline $\begin{array}{c}\text { Corrective } \\
\text { Action Site }\end{array}$ & $\begin{array}{c}\text { Alternative 1 } \\
\text { No Further Action }\end{array}$ & $\begin{array}{c}\text { Alternative 2 } \\
\text { Clean Closure }\end{array}$ & $\begin{array}{c}\text { Alternative 3 } \\
\text { Close in Place } \\
\text { (with Administrative Controls) }\end{array}$ \\
\hline \hline $03-59-01$ & $\mathrm{X}$ & $\mathrm{X}$ & $\mathrm{X}$ \\
\hline $03-59-02$ & $\mathrm{X}$ & $\mathrm{X}$ & $\mathrm{X}$ \\
\hline $06-51-01$ & $\mathrm{X}$ & $\mathrm{X}$ & $\mathrm{X}$ \\
\hline $06-51-02^{\mathrm{a}}$ & $\mathrm{X}$ & -- & $\mathrm{X}$ \\
\hline $06-51-03$ & $\mathrm{X}$ & $\mathrm{X}$ & -- \\
\hline $22-19-04$ & $\mathrm{X}$ & -- & \\
\hline
\end{tabular}

\footnotetext{
a Surface debris was removed as an NTS housekeeping activity.

-- = Not applicable
} 


\subsubsection{Alternative 1 - No Further Action}

Under the No Further Action Alternative, no corrective action activities will be implemented. This alternative serves as a baseline case with which to compare and assess the other corrective action alternatives and their ability to meet the corrective action standards. This alternative meets the corrective action objectives for those components comprising each CAS that have no COCs present; thus, requiring that no corrective actions be taken to prevent exposure to COCs. Two of the CASs within CAU 516 do not need to be evaluated for additional corrective actions. The following subsections provide appropriate CAS-specific information evaluated with regard to Alternative 1, No Further Action.

\subsubsection{CAS 06-51-02, Clay Pipe and Debris}

There were no environmental or waste concerns identified for this CAS during the development of the CAIP or during the CAI. Surface debris was removed from this CAS during the CAI as part of the NTS housekeeping effort. Therefore, no corrective action is required and the requirements for Alternative 1, No Further Action, have been met.

\subsubsection{CAS 22-19-04, Vehicle Decontamination Area}

There were no COCs identified at CAS 22-19-04 during the CAI. Therefore, no corrective action is required and the requirements for Alternative 1, No Further Action, have been met.

\subsubsection{Alternative 2 - Clean Closure}

The Clean Closure Alternative will require the removal and proper disposal of all contaminated material. The following remedial activities are applicable to Alternative 2 - Clean Closure:

- Remove contaminated material (e.g., septic tank contents, soil) and transport to an appropriate disposal facility.

- Remove septic system components in accordance with regulatory disposal criteria and transport to an appropriate disposal facility.

- Collect rinsate samples, as necessary, and analyze for contaminants. 
- Collect verification samples from the underlying soil and analyze for the presence of contaminants.

- Backfill excavations using clean overburden and fill material.

- Return excavated areas to surface conditions compatible with the intended future use of the site.

- Seal (e.g., plug, cap, grout) any piping left in place that has the potential to provide a continuing migration pathway.

Alternative 2 meets the corrective action objectives for components of each CAS in which COCs are present. Corrective actions under Alternative 2 removes the source and prevents exposure to COCs.

The following subsections provide appropriate CAS-specific information evaluated with regard to Alternative 2, Clean Closure. Details of the cost assumptions are discussed in Appendix C (Cost Estimates for CAU 516).

\subsubsection{CAS 03-59-01, BIdg 3C-36 Septic System}

Total petroleum hydrocarbon-DRO is present in the septic tank solid contents. The TPH-DRO results are $3,600 \mathrm{mg} / \mathrm{kg}$ for the influent chamber and 7,800 $\mathrm{mg} / \mathrm{kg}$ for the effluent chamber requiring that the contents be disposed of as hydrocarbon waste. The contents of the tank will be removed and disposed of properly. The septic tank will be rinsed and a rinsate sample collected and analyzed to verify that the TPH-DRO has been removed from the tank. To verify the integrity of the septic tank, soil samples will be collected from the sides and bottom of the excavation to verify that TPH-DRO has not been released to the surrounding soil. The septic tank, contents, and rinsate will be disposed as hydrocarbon waste in accordance with the NAC 445A.2272 (NAC, 2003) and the NTS Landfill Permit SW12.097.02 (NDEP, 1997).

No material was present in the distribution box or the 10-ft section of septic system piping connecting the septic tank to the distribution box. Both components will be removed and disposed as construction debris as a best management practice.

Overburden, along with additional clean fill, will be used to backfill excavations after the removal of the components. The excavated areas will be returned to surface conditions compatible with the 
intended future use of the site. The ends of any remaining piping, having the potential to receive media, will be sealed (e.g., plugged, capped, grouted).

\subsubsection{CAS 03-59-02, BIdg 3C-45 Septic System}

Total Petroleum Hydrocarbon-DRO was detected in the solids of the septic tank. The solids in the effluent chamber contained 7,900 mg/kg TPH-DRO and the solids in the influent chamber contained $28,000 \mathrm{mg} / \mathrm{kg}$ TPH-DRO. These concentrations require that the solid be disposed of as hydrocarbon waste.

The chlorinated compounds 1,1-dichloroethene; 1,2-dichloroethane; and trichloroethene were present in the sediment in the influent chamber at concentrations of $6 \mathrm{mg} / \mathrm{L}, 0.96 \mathrm{mg} / \mathrm{L}$, and $4 \mathrm{mg} / \mathrm{L}$, respectively. These concentrations were established using TCLP methods. These concentrations are equal to or greater than the regulatory action levels of $0.7,0.5$, and $0.5 \mathrm{mg} / \mathrm{L}$, respectively. When removed, the solids should be managed as hazardous waste (RCRA waste codes D028, D029, and D040) and disposed of at a licensed hazardous waste treatment, storage, and disposal facility. Radiological analytical results indicate the solids meet the criteria in the NTS performance objective criteria (POC) for disposal off site as nonradioactive waste.

Alpha- and beta/gamma-emitting radionuclides were present in the liquid in the effluent chamber at concentrations of $104 \pm 20$ and $193 \pm 34 \mathrm{pCi} / \mathrm{L}$, respectively. These concentrations exceed the recommended levels for lagoon disposal. The liquid could be solidified, sampled, and disposed of at an appropriate NTS Landfill or the liquid could be disposed of in the Bilby Sump with NDEP's permission.

To verify the integrity of the septic tank, soil samples will be collected from the sides and bottom of the excavation to verify that TPH-DRO has not been released to the surrounding soil. The septic tank will be rinsed and a rinsate sample collected and analyzed to verify the absence of TPH-DRO, VOCs, and alpha- and beta/gamma-emitters.

Plutonium-239 is present at location B06 in the leachfield at a concentration of $7.3 \pm 1.1 \mathrm{pCi} / \mathrm{g}$ which only slightly exceeds the current PAL. Step-out sampling demonstrated that this contamination is limited in both horizontal and vertical extent. The lateral extent has been estimated to be 
approximately $10 \mathrm{ft}$ in any direction from the sample point and only the soil between 5.5 and $6.5 \mathrm{ft}$ bgs shows $\mathrm{Pu}-239$ at concentration greater than the PAL. The sample interval below this contamination (8.5 to $9.5 \mathrm{ft}$ bgs) did not show Pu-239 at a concentration that exceeded the PAL. Approximately $35 \mathrm{yd}^{3}$ of $\mathrm{Pu}-239$ contaminated soil will be excavated for disposal. The uncontaminated material above $5.5 \mathrm{ft}$ will be stockpiled and used to backfill the excavated area. The contaminated soil will be disposed as low-level waste in the Area 5 Low-Level Waste Disposal Site. Verification soil samples from the sides and bottom of the excavation will be collected and analyzed for Pu-239.

Contaminants of concern were not identified in the distribution box or the two dry wells. The distribution box will be removed as a best management practice and disposed as construction debris. The first $10 \mathrm{ft}$ of the photoprocessing dry well and of the dry well west of the Building 3C-45 foundation will be removed and the excavation backfilled. The removed material will be characterized and disposed of appropriately.

The ends of any remaining piping having the potential to receive media will be sealed (e.g., plugged, capped, grouted). The excavated areas will be returned to surface conditions compatible with the intended future use of the site. Overburden, along with additional clean fill, will be used to backfill excavations after removal of the contaminated material.

\subsubsection{CAS 06-51-01, Sump and Piping}

Total petroleum hydrocarbon-DRO was detected at a concentration of $220 \mathrm{mg} / \mathrm{kg}$ in the sediment composited from the ends of an 82-ft section of septic system piping (part of the total $275 \mathrm{ft}$ of piping connecting Building 660 to the sump). Because this material is considered uncontained, this concentration is considered to exceed the regulatory action level of $100 \mathrm{mg} / \mathrm{kg}$ (NAC, 2003). This section of pipe and its contents will be removed and disposed of as hydrocarbon waste. Verification samples will be collected from the underlying soil and analyzed to verify the absence of TPH-DRO.

The remaining piping of the $275 \mathrm{ft}$ of pipe will be sealed (e.g., plugged, capped, grouted). The excavated areas will be returned to surface conditions compatible with the intended future use of the site. Overburden, along with additional clean fill, will be used to backfill excavations after removal of the contaminated material. 


\subsubsection{CAS 06-51-03, Clean Out Box and Piping}

Total petroleum Hydrocarbon-DRO is present in the uncontained soil in the clean-out box at a concentration of $180 \mathrm{mg} / \mathrm{kg}$, which exceeds the regulatory action level of $100 \mathrm{mg} / \mathrm{kg}$ (NAC, 2003). The clean-out box contents will be removed and disposed of as hydrocarbon waste. In addition, the clean-out box and associated piping will be handled as hydrocarbon impacted-material, removed as a best management practice, and disposed of as hydrocarbon waste. Verification samples will be collected from the underlying soil and analyzed to verify the absence of TPH-DRO.

The ends of any remaining piping having the potential to receive media will be sealed (e.g., plugged, capped, grouted). The excavated areas will be returned to surface conditions compatible with the intended future use of the site. Overburden, along with additional clean fill, will be used to backfill excavations after removal of the contaminated material.

\subsubsection{Alternative 3 - Close in Place with Administrative Controls}

Alternative 3 uses administrative controls to prevent inadvertent contact with COCs. These controls would consist of use restrictions to minimize access and prevent unauthorized intrusive activities. The future use of CAU 516 would be restricted from any activity that would alter or modify the containment control unless concurrence was obtained from NDEP.

The following subsections provide appropriate CAS-specific information evaluated with regard to Alternative 3, Closure in Place with Administrative Controls. Details of the cost assumptions are discussed in Appendix C (Cost Estimates for CAU 516).

\subsubsection{CAS 03-59-01, Bldg 3C-36 Septic System}

Total petroleum hydrocarbons-DRO contamination is present in the septic tank solids at concentrations of $3,600 \mathrm{mg} / \mathrm{kg}$ and $7,800 \mathrm{mg} / \mathrm{kg}$. To comply with NAC 444 (NAC, 2002), the contents of the septic tank must be removed and the tank filled with an inert material (i.e., sand or dirt) or removed. This satisfies the elements of Alternative 3, Close in Place and Alternative 2, Clean Closure. 


\subsubsection{CAS 03-59-02, BIdg 3C-45 Septic System}

The leachfield location B06 is contaminated with Pu-239 at a concentration exceeding the PAL. The volume of contaminated soil at this location can be adequately addressed under Alternative 3 .

Closing in place the immediate area (approximately $100 \mathrm{ft}^{2}$ surrounding location B06 in the leachfield has administrative activities and costs associated with the use restriction. Administrative controls will be implemented to restrict inadvertent contact with contaminated media. Installation of a perimeter fence with appropriate signage around leachfield location B06 is recommended for this alternative. The future use of the CAS would be restricted from any activity that would alter or modify the containment control unless concurrence was obtained from the NDEP.

The following evaluation of NAC 445A.227 (2) (a-k) (NAC, 2003) supports the protection of groundwater from $\mathrm{Pu}-239$ at this CAS:

a. The average depth of groundwater in Area 3 is $754 \mathrm{ft} \mathrm{bgs} \mathrm{(Geomedia,} \mathrm{2002).} \mathrm{Groundwater}$ flow is generally to the southwest towards the Ash Meadows Discharge area (DOE/NV, 1996).

b. Water Well $\mathrm{C} 1$ is approximately $8 \mathrm{mi}$ southeast of this CAS. Depth to groundwater is approximately $1,707 \mathrm{ft}$ bgs (DOE/NV, 1996).

c. Soil contaminated with $\mathrm{Pu}-239$ was detected between 5.5 and $6.5 \mathrm{ft}$ bgs at location B06, which is located at the proximal end of the leachfield. Additional samples were collected within $20 \mathrm{ft}$ laterally and $8.5 \mathrm{ft}$ vertically of location B06 to determine the vertical and lateral extent of contamination. Results from vertical and lateral step-out sampling did not show the presence of contamination. Based on the relatively low concentration of contamination and the fact that the duplicate sample did not contain $\mathrm{Pu}-239$ at a concentration greater than the PAL, the lateral extent is assumed to be limited to within $10 \mathrm{ft}$ of location B06.

d. Average annual precipitation for valleys in the South-Central Great Basin ranges from 3 to 6 in. Annual evaporation is roughly 5 to 25 times the annual precipitation (Winograd and Thordarson, 1975). The high evaporation and low precipitation rates create a negative water balance for the area; therefore, no driving force associated with precipitation is available to mobilize the COC vertically.

e. The Pu-239 contaminated leachfield soil at location B06 is not physically contained; however, the downward migration of $\mathrm{COCs}$ is slowed by the following parameters:

- Volume of release - it is assumed that small volumes of Pu-239 was released over a long period of time rather than a large volume over a short duration. 
- Soil saturation - the soil tends to be slightly damp to dry where the COCs are located. Therefore, increasing the adsorption and reducing the mobility of the COC.

- Soil particle adsorption/desorption - radionuclides tend to adsorb to the soil particles with little desorption as suggested by the limited vertical migration of COCs.

f. The lateral extent of the soil contamination is defined by analytical data indicated by the lack of contamination found in the nearby sampling locations; thereby, demonstrating minimal lateral mobility. Contamination concentrations below the sampling horizons were significantly lower, demonstrating minimal vertical migration. Based on analytical data, the vertical extent of contamination is confined to $6.5 \mathrm{ft}$ bgs.

g. Presently, this CAS is located on a government-controlled facility. The NTS is a restricted area that is guarded on a 24-hour, 365-day per year basis; unauthorized personnel are not admitted to the facility. This CAS is contained within a restricted use zone classified as a "Nuclear and High Explosives Test Zone," which is designated within the Nuclear Test Zone for additional underground and outdoor high-explosive tests or experiments. This zone includes compatible defense and nondefense research, development, and testing projects and activities (DOE/NV, 1996).

h. Preferred routes of vertical and lateral migration are nonexistent since the sources of contamination have been eliminated and the driving forces are not viable.

i. See Section 3.3.2.2 for site-specific considerations.

j. The potential for a hazard related to fire, vapor, or explosion is nonexistent for the COC at the site.

k. No other site-specific factors are known at this site.

Based on this evaluation, impacts to groundwater are not expected. Therefore, groundwater monitoring is not proposed for this site and is not considered an element of Alternative 3.

Total petroleum hydrocarbons-DRO $(28,000 \mathrm{mg} / \mathrm{kg})$ and the chlorinated compounds 1,1-dichloroethene (6 mg/L); 1,2-dichloroethene $(0.96 \mathrm{mg} / \mathrm{L})$; and trichloroethene $(4 \mathrm{mg} / \mathrm{L})$ were detected at concentrations exceeding regulatory limits. To comply with the NAC 444 (NAC, 2002), the contents of the septic tank will be removed and the tank filled with an inert material (i.e., sand or dirt). This satisfied the elements of Alternative 3, Close in Place, and Alternative 2, Clean Closure. 


\subsubsection{CAS 06-51-01, Sump and Piping}

Total petroleum hydrocarbon-DRO was present in the sediment in an 82-ft segment of pipe at a concentration of $220 \mathrm{mg} / \mathrm{kg}$. This concentration exceeds the PAL of $100 \mathrm{ppm}$ (NAC, 2003).

Closing the 82-ft section of contaminated septic system piping in place has administrative activities and costs associated with the use restriction. Administrative controls will be implemented to restrict inadvertent contact with contaminated media. Installation of a perimeter fence with appropriate signage around the piping is recommended for this alternative. The future use of the CAS would be restricted from any activity that would alter or modify the containment control unless appropriate concurrence was obtained from NDEP.

The following evaluation of NAC 445A.227 (2) (a-k) (NAC, 2003) supports the protection of groundwater from TPH-DRO at this CAS:

a. The groundwater average depth in Area 6 is 1,531 ft bgs (USGS, 2002). Groundwater flow is generally to the southwest towards the Ash Meadows discharge area (DOE/NV, 1996).

b. Water Well C1 is approximately $5.5 \mathrm{mi}$ southeast of this CAS. Depth to groundwater at this well is approximately $1,707 \mathrm{ft}$ bgs (DOE/NV, 1996).

c. TPH-DRO is present at $220 \mathrm{mg} / \mathrm{kg}$ in a soil sample collected and composited from each end of the 82-ft section of pipe buried approximately $6 \mathrm{ft}$ bgs.

d. Average annual precipitation for valleys in the South-Central Great Basin ranges from 3 to 6 in. Annual evaporation is roughly 5 to 25 times the annual precipitation (Winograd and Thordarson, 1975). The high evaporation and low precipitation rates create a negative water balance for the area; therefore, no driving force associated with precipitation is available to mobilize the TPH-DRO vertically.

e. The TPH-DRO contaminants detected at the ends of an 82-ft section of septic system piping is contained within the pipe.

f. The additional samples collected at locations C02 and D04 indicate that the TPH-DRO contamination is contained within the pipe. The pipe is buried $6 \mathrm{ft} \mathrm{bgs}$ and is secured by uncontaminated overburden, reducing the possibility of exposure.

g. Presently, this CAS is located on a government-controlled facility. The NTS is a restricted area that is guarded on a 24-hour, 365-day per year basis; unauthorized personnel are not admitted to the facility. This CAS is contained within a restricted use zone classified as a 
Defense Industrial Zone which is designated for stockpile management of weapons, including production, assembly, disassembly or modification, staging, repair, retrofit, and surveillance. Also included in this zone are permanent facilities for stockpile stewardship operations involving equipment and activities such as radiography, lasers, materials processing, and pulsed power (DOE/NV, 1996).

h. Preferred routes of vertical and lateral migration are nonexistent since the sources have been eliminated, the TPH-DRO is contained within the pipe, and driving forces are not viable.

i. See Section 3.3.2.4 for site-specific considerations.

j. The potential for a hazard related to fire, vapor, or explosion is nonexistent for the COC at the site.

k. No other site-specific factors are known at this site.

Based on this evaluation, impacts to groundwater are not expected. Therefore, groundwater monitoring is not proposed for this site and is not considered an element of Alternative 3.

\subsubsection{CAS 06-51-03, Clean Out Box and Piping}

The TPH-DRO contaminated material in the open clean-out box is present at a concentration of $180 \mathrm{mg} / \mathrm{kg}$, exceeding the PAL of $100 \mathrm{ppm}$ (NAC, 2003). To prevent the possibility of migration and inadvertent contact with the contaminated media, the clean-out box content of approximately $0.5 \mathrm{yd}^{3}$ will be removed under Alternative 2, Clean Closure.

The costs associated with containing $0.5 \mathrm{yd}^{3}$ of contaminated contents in the clean-out box does not make Alternative 3, Closure in Place, a viable option.

\subsection{Evaluation and Comparison of Alternatives}

The general corrective action standards and remedy selection decision factors described in Section 3.2 were used to conduct detailed and comparative analyses of each corrective action alternative presented in Section 3.3. The advantages and disadvantages of each alternative were assessed to select preferred alternatives for CAU 516. Table 3-2 and Table 3-3 present the detailed comparative evaluation of closure alternatives for each CAS requiring corrective action, including recommended best management practices. The cost estimates listed in Table 3-2 and Table 3-3 are detailed in Appendix C. 
Table 3-2

Detailed Evaluation of Alternatives for Corrective Action Unit 516 (Page 1 of 4 )

\begin{tabular}{|c|c|c|c|}
\hline Evaluation Criteria & $\begin{array}{c}\text { Alternative } 1 \\
\text { No Further Action }\end{array}$ & $\begin{array}{l}\text { Alternative } 2 \\
\text { Clean Closure }\end{array}$ & $\begin{array}{c}\text { Alternative } 3 \\
\text { Closure in Place with Administrative } \\
\text { Controls }\end{array}$ \\
\hline \multicolumn{4}{|l|}{ Closure Standards } \\
\hline $\begin{array}{l}\text { Protection of Human Health and the } \\
\text { Environment }\end{array}$ & $\begin{array}{l}\text { Does not meet corrective action } \\
\text { objective of preventing or mitigating } \\
\text { exposure to surface and subsurface } \\
\text { soil containing COCs or media } \\
\text { exceeding unrestricted release } \\
\text { criteria. } \\
\text { - Does not meet corrective action } \\
\text { objective of preventing or mitigating } \\
\text { exposure to tank contents with } \\
\text { concentrations. } \\
\text { Does not prevent potential spread of } \\
\text { COCs. } \\
\text { - No worker exposure associated with } \\
\text { implementation. }\end{array}$ & $\begin{array}{l}\text { Meets corrective action objectives. } \\
\text { Low to moderate risk to workers } \\
\text { associated with use of heavy } \\
\text { equipment and potential contact } \\
\text { with impacted media during } \\
\text { excavation, transportation, and } \\
\text { closure activities. } \\
\text { - Low risk to public due to remote } \\
\text { location and controlled access to } \\
\text { NTS. Low to moderate risk to public } \\
\text { during transportation off NTS. } \\
\text { Moving contaminated media to an } \\
\text { appropriate disposal facility } \\
\text { mitigates exposure to impacted } \\
\text { media after closure. }\end{array}$ & $\begin{array}{l}\text { - Meets corrective action objectives. } \\
\text { Prevents inadvertent intrusion into } \\
\text { the contaminated media. } \\
\text { use of heavy equipment and } \\
\text { potential contact with impacted } \\
\text { media during closure activities. } \\
\text { - Low risk to public because of } \\
\text { remote location and controlled } \\
\text { access to the NTS. } \\
\text { NAC 445A.227 (2) (a-k) analysis } \\
\text { shows the contaminants are not } \\
\text { expected to impact groundwater. }\end{array}$ \\
\hline $\begin{array}{l}\text { Compliance with Media Cleanup } \\
\text { Standards }\end{array}$ & $\begin{array}{l}\text { Does not comply with media } \\
\text { cleanup standards because COCs } \\
\text { exceeding hydrocarbon criteria } \\
\text { remain. }\end{array}$ & $\begin{array}{l}\text { Complies with media cleanup } \\
\text { standards because media } \\
\text { containing COCs will be excavated } \\
\text { and disposed at an appropriate } \\
\text { disposal facility. } \\
\text { Removal of COCs will be verified } \\
\text { with confirmation sampling. }\end{array}$ & $\begin{array}{l}\text { - Complies with media cleanup } \\
\text { standards by controlling exposure } \\
\text { pathways. } \\
\text { - NAC 445A.227 (2) (a-k) analysis } \\
\text { shows the contaminants are not } \\
\text { expected to impact groundwater. }\end{array}$ \\
\hline Control the Source(s) of Release & $\begin{array}{l}\text { - The sources at each CAS have } \\
\text { been discontinued. }\end{array}$ & $\begin{array}{l}\text { - The sources at each CAS have } \\
\text { been discontinued. }\end{array}$ & $\begin{array}{l}\text { - The sources at each CAS have } \\
\text { been discontinued. }\end{array}$ \\
\hline
\end{tabular}


Table 3-2

Detailed Evaluation of Alternatives for Corrective Action Unit 516 (Page 2 of 4 )

\begin{tabular}{|c|c|c|c|}
\hline Evaluation Criteria & $\begin{array}{c}\text { Alternative } 1 \\
\text { No Further Action }\end{array}$ & $\begin{array}{l}\text { Alternative } 2 \\
\text { Clean Closure }\end{array}$ & $\begin{array}{c}\text { Alternative } 3 \\
\text { Closure in Place with Administrative } \\
\text { Controls }\end{array}$ \\
\hline $\begin{array}{l}\text { Comply with Applicable Federal, State, } \\
\text { and Local Standards for Waste } \\
\text { Management }\end{array}$ & - No waste generated & $\begin{array}{l}\text { All waste (primarily liquid, sediment, } \\
\text { contaminated soil, system } \\
\text { components, and disposable } \\
\text { personal protective equipment) will } \\
\text { be handled and disposed in } \\
\text { accordance with applicable } \\
\text { standards. }\end{array}$ & $\begin{array}{l}\text { All waste (primarily disposable } \\
\text { personal protective equipment, } \\
\text { system components) will be handled } \\
\text { and disposed in accordance with } \\
\text { applicable standards. }\end{array}$ \\
\hline \multicolumn{4}{|l|}{ Remedy Selection Decision Factors } \\
\hline $\begin{array}{l}\text { Short-Term Reliability and } \\
\text { Effectiveness }\end{array}$ & - Not evaluated & $\begin{array}{l}\text { - Low risk to workers associated with } \\
\text { use of heavy equipment and } \\
\text { potential contact with impacted } \\
\text { media during excavation, } \\
\text { transportation, and closure } \\
\text { activities. } \\
\text { - Public protected during removal by } \\
\text { remote location and NTS site } \\
\text { access controls. } \\
\text { - Low to moderate risk to public } \\
\text { during transportation off NTS. } \\
\text { Environmental impacts are not } \\
\text { anticipated due to implementation. } \\
\text { Appropriate measures will be taken } \\
\text { at the site to protect desert tortoises. } \\
\text { Implementation should not require } \\
\text { an extended period of time. }\end{array}$ & $\begin{array}{l}\text { - Low risk to workers associated with } \\
\text { use of heavy equipment and } \\
\text { potential contact with impacted } \\
\text { media during closure activities. } \\
\text { - Public protected by remote location } \\
\text { and NTS site access controls. } \\
\text { - Environmental impacts are not } \\
\text { anticipated due to implementation. } \\
\text { Appropriate measures will be taken } \\
\text { at the site to protect desert tortoises. } \\
\text { Implementation should not require } \\
\text { an extended period of time. }\end{array}$ \\
\hline
\end{tabular}


Table 3-2

Detailed Evaluation of Alternatives for Corrective Action Unit 516 (Page 3 of 4)

\begin{tabular}{|c|c|c|c|}
\hline Evaluation Criteria & $\begin{array}{c}\text { Alternative } 1 \\
\text { No Further Action }\end{array}$ & $\begin{array}{l}\text { Alternative } 2 \\
\text { Clean Closure }\end{array}$ & $\begin{array}{c}\text { Alternative } 3 \\
\text { Closure in Place with Administrative } \\
\text { Controls }\end{array}$ \\
\hline $\begin{array}{l}\text { Reduction of Toxicity, Mobility, and/or } \\
\text { Volume }\end{array}$ & - Not evaluated & $\begin{array}{l}\text { Clean closure would eliminate } \\
\text { associated toxicity, mobility, and } \\
\text { volume of wastes at each CAS. } \\
\text { Proper disposal of the waste will } \\
\text { result in an reduction of mobility. }\end{array}$ & $\begin{array}{l}\text { - The mobility of the remaining tank } \\
\text { and system components } \\
\text { contamination is significantly } \\
\text { reduced by administrative controls, } \\
\text { solidification of any free liquid, and } \\
\text { lack of viable driving forces. } \\
\text { - The volume of contaminated tank } \\
\text { and system components is } \\
\text { increased through the addition of } \\
\text { solidification material. } \\
\text { Toxicity and volume of the soil } \\
\text { contamination are effectively } \\
\text { unchanged. }\end{array}$ \\
\hline $\begin{array}{l}\text { Long-Term Reliability and } \\
\text { Effectiveness }\end{array}$ & - Not evaluated & $\begin{array}{l}\text { - All risk will be eliminated upon } \\
\text { completion. } \\
\text { - No maintenance required. } \\
\text { - Moving contaminated media to an } \\
\text { appropriate disposal media facility } \\
\text { will minimize future mobility. }\end{array}$ & $\begin{array}{l}\text { - Controls inadvertent intrusion to } \\
\text { remaining contaminated media. } \\
\text { - Administrative controls must be } \\
\text { maintained. }\end{array}$ \\
\hline Feasibility & - Not evaluated & $\begin{array}{l}\text { - Depth of contaminated soil would } \\
\text { require excavation and shoring to } \\
\text { protect workers. } \\
\text { - Removal of contaminated media } \\
\text { from the septic tanks would require } \\
\text { controls to protect workers. } \\
\text { - Options for disposal of } \\
\text { contaminated media is limited and } \\
\text { require coordination with multiple } \\
\text { entities. }\end{array}$ & $\begin{array}{l}\text { Coordination of all entities is } \\
\text { necessary to ensure compliance } \\
\text { with administrative controls to } \\
\text { prevent intrusion into contaminated } \\
\text { zones. }\end{array}$ \\
\hline
\end{tabular}


Table 3-2

Detailed Evaluation of Alternatives for Corrective Action Unit 516 (Page 4 of 4 )

\begin{tabular}{|c|c|c|c|}
\hline Evaluation Criteria & $\begin{array}{c}\text { Alternative } 1 \\
\text { No Further Action }\end{array}$ & $\begin{array}{c}\text { Alternative } 2 \\
\text { Clean Closure }\end{array}$ & $\begin{array}{c}\text { Alternative } 3 \\
\text { Closure in Place with Administrative } \\
\text { Controls }\end{array}$ \\
\hline Cost & $\begin{array}{l}\text { Alternative I: } \\
\text { CAS 03-59-01 }=\$ 0 \\
\text { CAS 03-59-02 }=\$ 0 \\
\text { CAS 06-51-01 }=\$ 0 \\
\text { CAS 06-51-03 }=\$ 0 \\
\text { CAS 22-19-04 }=\$ 0\end{array}$ & $\begin{array}{l}\text { Alternative 2: } \\
\text { CAS 03-59-01 }=\$ 211,173 \\
\text { CAS 03-59-02 }=\$ 458,742 \\
\text { CAS 06-51-01 }=\$ 115,696 \\
\text { CAS 06-51-03 }=\$ 141,903 \\
\text { CAS 22-19-04 }=\text { NA }\end{array}$ & $\begin{array}{ll}\text { Alternative 3: } & \\
\text { CAS 03-59-01 } & =\$ 95,273 \\
\text { CAS 03-59-02 } & =\$ 118,767 \\
\text { CAS 06-51-01 } & =\$ 92,766 \\
\text { CAS 06-51-03 } & =\$ 92,766 \\
\text { CAS 22-19-04 } & =\text { NA }\end{array}$ \\
\hline
\end{tabular}

NA = Not applicable 
Table 3-3

Comparative Evaluation of Alternatives for Corrective Action Unit 516

\begin{tabular}{|c|c|c|c|}
\hline Evaluation Criteria & \multicolumn{3}{|c|}{ Comparative Evaluation } \\
\hline \multicolumn{4}{|l|}{ Closure Standards } \\
\hline $\begin{array}{l}\text { Protection of Human Health and the } \\
\text { Environment }\end{array}$ & \multicolumn{3}{|c|}{$\begin{array}{l}\text { Alternatives } 2 \text { and } 3 \text { meet corrective action objectives. No worker exposures to risks are associated with Alternative } 1 . \\
\text { Lower short-term risks are associated with Alternative } 3 \text { and slightly higher short-term (during the excavation) risks with } \\
\text { Alternative 2. Nevada Administrative Code 445A.227 (2) (a-k) analysis shows the contaminants are not threatening } \\
\text { groundwater. }\end{array}$} \\
\hline $\begin{array}{l}\text { Compliance with Media Cleanup } \\
\text { Standards }\end{array}$ & \multicolumn{3}{|c|}{$\begin{array}{l}\text { Alternative } 1 \text { does not involve contaminated media. Alternative } 2 \text { meets media cleanup standards by removing } \\
\text { contaminated media and eliminating exposure pathways at the site. Alternative } 3 \text { controls access to contaminants, } \\
\text { effectively eliminating exposure pathways. NAC 445A.272 requires the removal and disposal of septic tank contents. }\end{array}$} \\
\hline Control the Source(s) of Release & \multicolumn{3}{|c|}{$\begin{array}{l}\text { The sources at each CAS have been discontinued. Alternative } 2 \text { would eliminate any residual contamination that is } \\
\text { present. }\end{array}$} \\
\hline $\begin{array}{l}\text { Comply with Applicable Federal, State, } \\
\text { and Local Standards for Waste } \\
\text { Management }\end{array}$ & \multicolumn{3}{|c|}{$\begin{array}{l}\text { Alternative } 1 \text { does not generate waste. Alternatives } 2 \text { and } 3 \text { will generate waste that will be handled in accordance with } \\
\text { applicable closure standards and regulatory requirements. }\end{array}$} \\
\hline \multicolumn{4}{|l|}{ Remedy Selection Decision Factors } \\
\hline $\begin{array}{l}\text { Short-Term Reliability and } \\
\text { Effectiveness }\end{array}$ & \multicolumn{3}{|c|}{ Lower risks are associated with Alternative 3 and slightly higher risks with Alternative 2.} \\
\hline $\begin{array}{l}\text { Reduction of Toxicity, Mobility, and/or } \\
\text { Volume }\end{array}$ & \multicolumn{3}{|c|}{$\begin{array}{l}\text { Alternative } 2 \text { results in an immediate reduction of all three characteristics at each CAS. Alternative } 3 \text { results in a reduction } \\
\text { of potential inadvertent contact, but does not reduce toxicity or volume. }\end{array}$} \\
\hline $\begin{array}{l}\text { Long-Term Reliability and } \\
\text { Effectiveness }\end{array}$ & \multicolumn{3}{|c|}{$\begin{array}{l}\text { Residual risk at each CAS is low for Alternative } 3 \text { and nonexistent for Alternative } 2 \text {. Alternative } 3 \text { requires administrative } \\
\text { measures to control intrusive activities. }\end{array}$} \\
\hline Feasibility & \multicolumn{3}{|c|}{$\begin{array}{l}\text { Alternatives } 2 \text { and } 3 \text { are feasible. However, Alternative } 2 \text { will be more resource intensive initially and Alternate } 3 \text { will } \\
\text { require continual administrative involvement. }\end{array}$} \\
\hline Cost & $\begin{array}{ll}\text { Alternative 1: } & \\
\text { CAS 03-59-01 } & =\$ 0 \\
\text { CAS 03-59-02 } & =\$ 0 \\
\text { CAS 06-51-01 } & =\$ 0 \\
\text { CAS 06-51-03 } & =\$ 0 \\
\text { CAS 22-19-04 } & =\$ 0\end{array}$ & $\begin{array}{ll}\text { Alternative 2: } & \\
\text { CAS 03-59-01 } & =\$ 211,173 \\
\text { CAS 03-59-02 } & =\$ 458,742 \\
\text { CAS 06-51-01 } & =\$ 115,696 \\
\text { CAS 06-51-03 } & =\$ 141,903 \\
\text { CAS 22-19-04 } & =\text { NA }\end{array}$ & $\begin{array}{ll}\text { Alternative 3: } & \\
\text { CAS 03-59-01 } & =\$ 95,273 \\
\text { CAS 03-59-02 } & =\$ 118,767 \\
\text { CAS 06-51-01 } & =\$ 92,766 \\
\text { CAS 06-51-03 } & =\$ 92,766 \\
\text { CAS 22-19-04 } & =\mathrm{NA}\end{array}$ \\
\hline
\end{tabular}

NA = Not applicable 


\subsection{Recommended Alternative}

The preferred corrective action alternatives were evaluated on corrective action standards decision and remedy selection factors, their technical merits (focusing on performance, reliability, feasibility), and safety. The selected alternatives were judged to meet all requirements for the technical components evaluated. The selected alternatives meet all applicable state and federal regulations for closure of the sites and will minimize potential future exposure pathways to the contaminated media at CAU 516. Cost estimates were used to support the selection of preferred corrective action alternatives. Figure 4-1, Figure 4-2, and Figure 4-3 show the areas where the activities for the preferred closure recommendations will be conducted.

Alternative 1, No Further Action, is the preferred corrective action for the following CASs:

- CAS 06-51-02 - Housekeeping debris was removed during the CAI; no environmental waste or concerns remain.

- CAS 22-19-04 - There were no COCs identified; therefore, this CAS does not require corrective action.

Alternative 2, Clean Closure, is the preferred corrective action for the following CASs:

- CAS 03-59-01 - Clean close by removing the contaminated contents of the septic tank. As a best management practice, remove the septic tank, distribution box, and the 10 - $\mathrm{ft}$ section of pipe connecting the septic tank to the distribution box; and seal the open ends of the piping (Figure 4-1).

- CAS 03-59-02 - Clean close by removing $35 \mathrm{yd}^{3}$ of contaminated soil at location B06 in the leachfield. Clean close the septic tank by removing septic tank contents and the septic tank. Remove the distribution box and seal the open ends of the piping as a best management practice. In addition, remove the photoprocessing dry well (to a depth of between 12 and $17 \mathrm{ft}$ deep) and the first $10 \mathrm{ft}$ of the dry well located west of the Building 3C-45 (44 ft deep), and backfill both dry wells with clean native material (Figure 4-2).

- CAS 06-51-01 - Clean close by removing $82 \mathrm{ft}$ of contaminated piping running between Building 660 and the sump (Figure 4-3). Seal the open ends of the piping as a best management practice.

- CAS 06-51-03 - Clean close by removing the contaminated contents of the clean-out box and the clean-out box. Remove the associated piping and seal the open ends of the piping as a best management practice (Figure 4-3). 


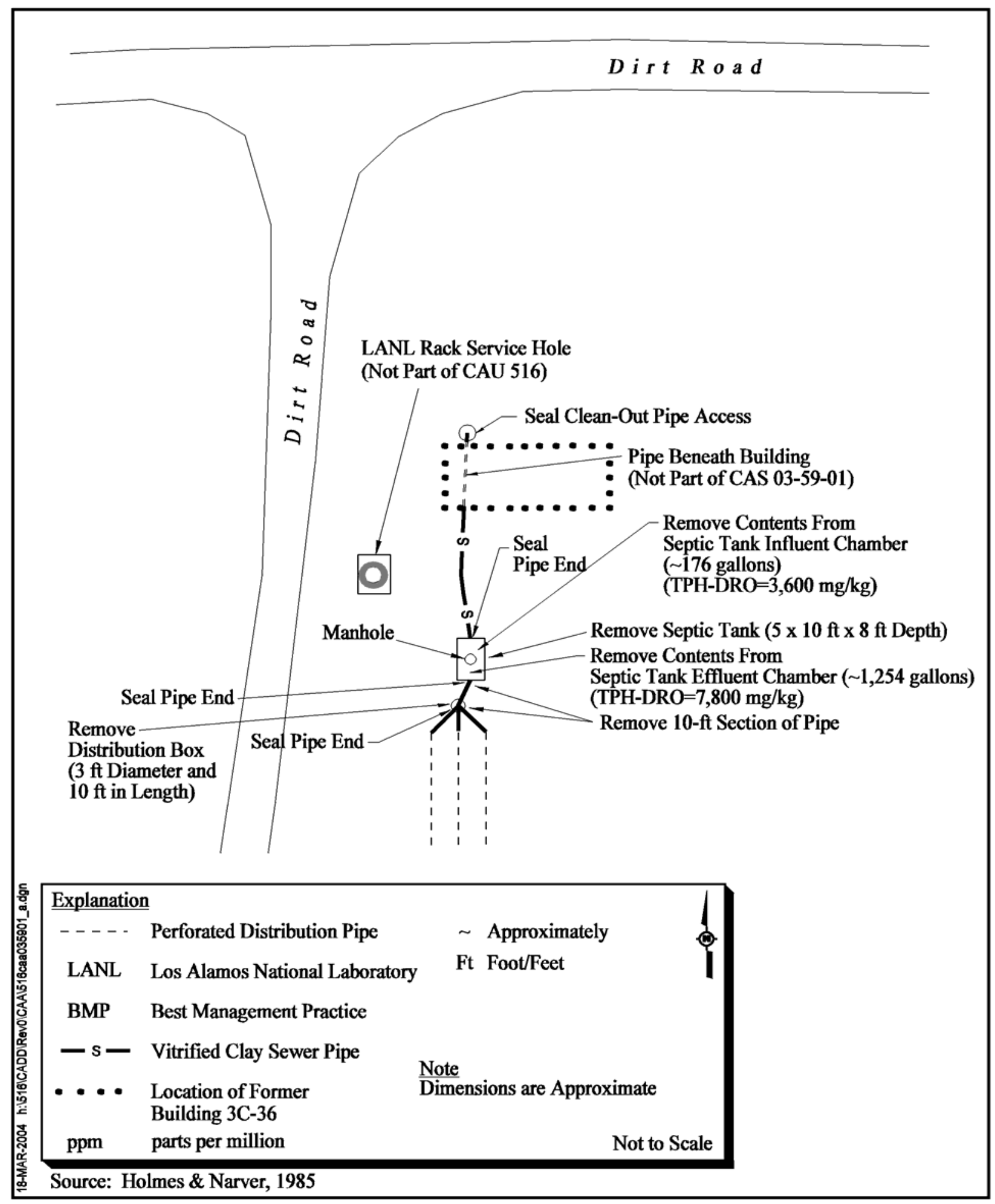

Figure 4-1

CAU 516, CAS 03-59-01, BIdg 3C-36 Septic System, Recommended Closure Alternative: Clean Closure 


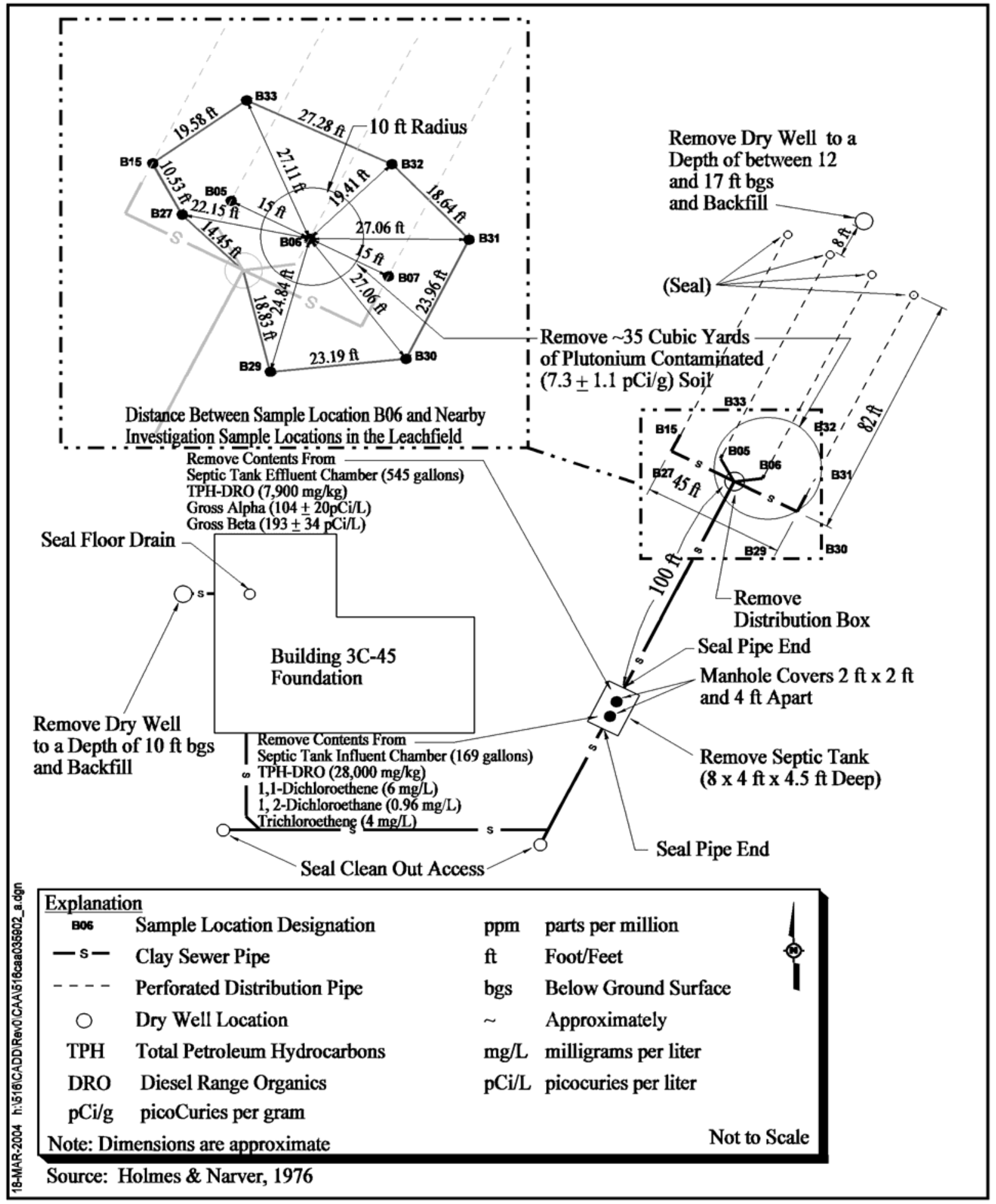

Figure 4-2

CAU 516, CAS 03-59-02, BIdg 3C-45 Septic System, Recommended Closure Alternative: Clean Closure 


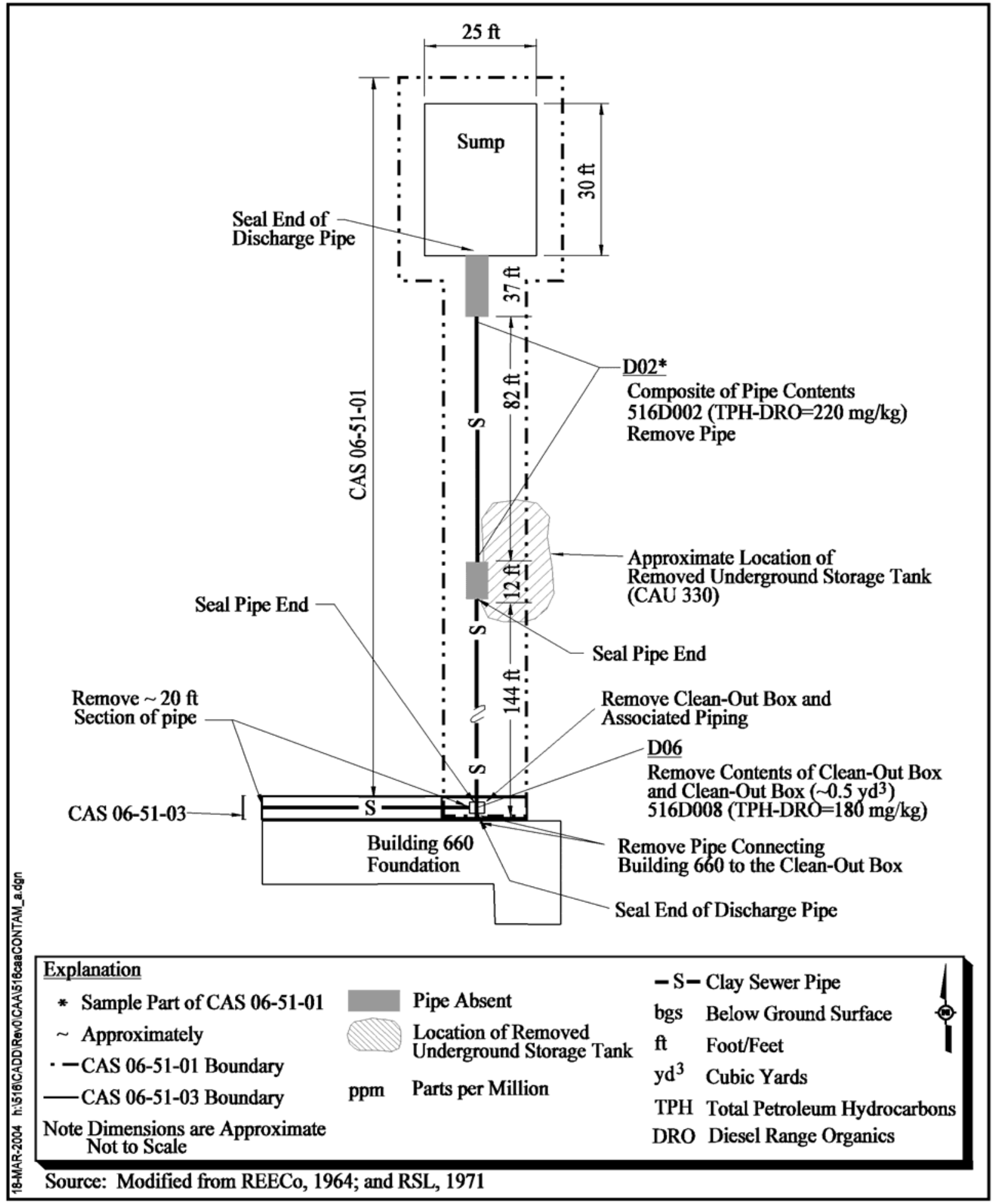

Figure 4-3

CAU 516, CAS 06-51-01, Sump and Piping, and CAS 06-51-03, Clean Out Box and Piping, Recommended Closure Alternative: Clean Closure 


\subsection{References}

BN, see Bechtel Nevada.

Bechtel Nevada. 1995. Nevada Test Site Performance Objective for Certification of Nonradioactive Hazardous Waste, Rev. 0, G-E11/96.01. Las Vegas, NV.

CFR, see Code of Federal Regulations.

Code of Federal Regulations. 2003. Title 40 CFR Parts 260 - 282, "Hazardous Waste Management." Washington, DC: U.S. Government Printing Office.

DOE, see U.S. Department of Energy.

DOE/NV, see U.S. Department of Energy, Nevada Operations Office.

DRI, see Desert Research Institute.

Desert Research Institute. 1988. CERCLA Preliminary Assessment of DOE's Nevada Operations Office Nuclear Weapons Testing Areas, Vol. 1. Las Vegas, NV.

Desert Research Institute. 1993. Data Report ER-6-1 Hydrologic Testing and Geochemical Sampling Results, March. Prepared by D.R. Gillespie. Las Vegas, NV: Water Resources Center.

Desert Research Institute. 1996. Nevada Test Site Water Supply Wells. Prepared for the U.S. Department of Energy, Nevada Operations Office. Las Vegas, NV: Water Resources Center.

EPA, see U.S. Environmental Protection Agency.

FFACO, see Federal Facility Agreement and Consent Order.

Federal Facility Agreement and Consent Order. 1996 (as amended). Agreed to by the State of Nevada, the U.S. Department of Energy, and the U.S. Department of Defense.

Geomedia. 2002. Well Distances Obtained Through Software. Prepared for the U.S. Department of Energy, National Nuclear Security Administration Nevada Operations Office. Las Vegas, NV. 
Holmes \& Narver, Inc. 1976. Engineering drawing JS-003-3C-45-C2.1 entitled, "Nevada Test Site Area 3 LASL Building 3C-45 Rack and Compensator Fac. Addition Surface Treatment," 19 January. Mercury, NV: Archives and Records Center.

Holmes \& Narver, Inc. 1985. Engineering drawing JS-003-3C-36-C1.1 entitled, "Nevada Test Site Area 3 - Los Alamos Building No. 3C-36 WX-9 Office Complex Plot \& Grading Plan Details," 23 January. Mercury, NV: Archives and Records Center.

Moore, J., Science Applications International Corporation. 1999. Memo to M. Todd (ITLV), "Background Concentrations for NTS and TTR Soil Samples," 3 February. Las Vegas, NV.

NAC, see Nevada Administrative Code.

NBMG, see Nevada Bureau of Mines and Geology.

NCRP, see National Council on Radiation Protection and Measurements.

NDEP, see Nevada Division of Environmental Protection.

NNSA/NSO, see U.S. Department of Energy, National Nuclear Security Administration Nevada Site Office.

NNSA/NV, see U.S. Department of Energy, National Nuclear Security Administration Nevada Operations Office.

NRS, see Nevada Revised Statutes.

National Council on Radiation Protection and Measurement. 1999. Recommended Screening Limits for Contaminated Surface Soil and Review Factors Relevant to Site-Specific Studies, Report No. 129. Bethesda, MD.

Nevada Administrative Code. 2002. NAC 444.842 to 444.980, "Management of Hazardous Waste." Carson City, NV.

Nevada Administrative Code. 2003. NAC 445A, "Water Controls." Carson City, NV.

Nevada Bureau of Mines and Geology. 1998. Mineral and Energy Resource Assessment of the Nellis Air Force Range, Open-File Report 98-1. Reno, NV.

Nevada Division of Environmental Protection. 1997a (as amended in August 2000). Class III Solid Waste Disposal Site for Hydrocarbon Burdened Soils, Area 6 of the NTS, Permit SW 1309702. Reno, NV.

Nevada Division of Environmental Protection. 1997b (as amended). Class III Solid Waste Disposal Site; U10C, Area 9 of the NTS, Permit SW 1309703. Carson City, NV. 
Nevada Revised Statutes. 1998. NRS 459.400-459.600, "Disposal of Hazardous Waste." Carson City, NV.

REECo, see Reynolds Electrical \& Engineering Co., Inc.

RSL, see Remote Sensing Laboratory.

Remote Sensing Laboratory. 1971. Aerial Photograph of Well 3 Yard. Nellis Air Force Base, NV: Photo Archives Library.

Reynolds Electrical \& Engineering Co., Inc. 1964. Engineering Drawing RE-791A entitled, "U.S. Public Health Service Facilities for Milk Cows Plot Plan,” December. Mercury, NV: Archives and Record Center.

USGS, see U.S. Geological Survey.

U.S. Department of Energy. 1993. DOE Order 5400.5 Change 2, "Radiation Protection of the Public and the Environment." Washington, D.C.

U.S. Department of Energy, National Nuclear Security Administration Nevada Operations Office. 2002. Industrial Sites Quality Assurance Project Plan, Nevada Test Site, Nevada, Rev. 3, DOE/NV--372. Las Vegas, NV.

U.S. Department of Energy, National Nuclear Security Administration Nevada Site Office. 2003. Corrective Action Investigation Plan for Corrective Action Unit 516: Septic Systems and Discharge Points, Nevada Test Site, Nevada, DOE/NV--889. Las Vegas, NV.

U.S. Department of Energy, Nevada Operations Office. 1994. Project Management Plan, Rev. 0. Las Vegas, NV.

U.S. Department of Energy, Nevada Operations Office. 1996. Environmental Data Report for the Nevada Test Site - 1994, DOE/NV/11718-026, DOE/NV/11432-176. Prepared by S.C. Black and Y.E. Townsend of Bechtel Nevada. Las Vegas, NV.

U.S. Department of Energy, Nevada Operations Office. 1998. Nevada Test Site Resource Management Plan, DOE/NV-518. Las Vegas, NV.

U.S. Department of Energy, Nevada Operations Office. 2000. NV/YMP Radiological Control Manual Rev. 4, DOE/NV/11718-079. Prepared by Bechtel Nevada. Las Vegas, NV.

U.S. Environmental Protection Agency. 1991. Guidance on RCRA Corrective Action Decision Documents, EPA/540/G-91/011. Washington, DC: Office of Research and Development.

U.S. Environmental Protection Agency. 1994. Final RCRA Corrective Action Plan, EPA/520-R-94-004. Washington, DC: Office of Solid Waste and Emergency Response. 
U.S. Environmental Protection Agency. 2002. Region 9 Preliminary Remediation Goals (PRGs). As accessed at www.epa.gov/region09/waste/sfund/prg/index.htm, 8 January 2003. Prepared by S.J. Smucker. San Francisco, CA.

U.S. Geological Survey. 2002. "USGS/Department of Energy Cooperative Studies in Nevada." As accessed at http://nevada.usgs.gov/doe_nv/ on 25 February, 2002.

Winograd, I.J., and W. Thordarson. 1975. Hydrologic and Hydrochemical Framework South-Central Great Basin, Nevada-California, with Special Reference to the Nevada Test Site, USGS Professional Paper 712C. Washington, DC: U.S. Government Printing Office. 
Appendix A

Corrective Action Investigation Report for CAU 516 


\section{A.1.0 Introduction}

This appendix details the CAI activities and provides analytical results for CAU 516. The CAI was conducted in accordance with the CAIP (NNSA/NSO, 2003) as developed under the FFACO that was reviewed by the U.S. Department of Defense and approved by the State of Nevada (FFACO, 1996) prior to initiating field activities.

Corrective Action Unit 516 is comprised of six CASs located in Areas 3, 6, or 22 of the NTS (Figure 1-1). The CASs that are included in CAU 516 are:

- 03-59-01 - Bldg 3C-36 Septic System

- 03-59-02 - Bldg 3C-45 Septic System

- 06-51-01 - Sump and Piping

- 06-51-02 - Clay Pipe and Debris

- 06-51-03 - Clean Out Box and Piping

- 22-19-04 - Vehicle Decontamination Area

The CAU consists of CASs located at Area 3 Camp, Well 3 Yard in Area 6, and the Desert Rock Airport in Area 22. Corrective Action Site 03-59-01 located in Area 3 was a septic system associated with Building 3C-36. The other CAS in Area 3 (03-59-02) was a septic system and a dry well associated with Building 3C-45 and a dry well associated with a mobile photoprocessing trailer. Two of the CASs in Area 6 (CAS 06-51-01 and CAS 06-51-03) were parts of the septic system associated with Building 660, which was used by the U.S. Public Health Services in the 1960s as a feed barn, dairy barn, and slaughterhouse during the Animal Investigation Program. The building was later used for storage of parts, tools, and pipe fittings and as a calibration laboratory. The third CAS in Area 6 (06-51-02) is a debris removal CAS located west of Building 660. The CAS in Area 22 (22-19-04) was a vehicle decontamination area for the U.S. Army's Camp Desert Rock in the 1950s and early 1960s. This CAS was believed to have been used in association with nuclear weapons testing.

This CAU was investigated because process knowledge indicated that organic, inorganic, and/or radioactive constituents may be present at concentrations and locations that could potentially pose a threat to human health and the environment. Additional information regarding the history of each site, planning, and the scope of the investigation is presented in the CAIP (NNSA/NSO, 2003). 


\section{A.1.1 Objectives}

The primary objective of the investigation was to provide sufficient information and data to develop and evaluate appropriate corrective action alternatives for each CAS in CAU 516. This objective was achieved by identifying the absence or nature and extent of COCs (i.e., COPCs at concentrations above PALs).

The investigation strategy was developed during the DQO process and is presented in the CAIP (NNSA/NSO, 2003). The DQO process identified the potential sampling locations, analytical suite, and provided the logic and rationale that supported the sampling strategy.

\section{A.1.2 Content}

This appendix contains information and data to support the selection of a preferred corrective action alternative. The contents of this appendix are as follows:

- Section A.1.0 provides a brief summary and background of the CASs, objectives of the CAI, and appendix content.

- Section A.2.0 provides an investigation overview.

- Section A.3.0 through Section A.8.0 provide CAS-specific information regarding the field activities, sampling methods, and laboratory analytical results from the investigation.

- Section A.9.0 summarizes waste management activities.

- Section A.10.0 discusses the quality assurance (QA) and quality control procedures followed and the results of the QA/QC activities.

- Section A.11.0 is a summary of the investigation results.

- Section A.12.0 lists the cited references.

Documentation of field activities and laboratory data, including field activity daily logs (FADLs), sample collection logs, analysis request/chain-of-custody forms, laboratory certificates of analyses, analytical results, and surveillance results are retained in project files as hard copy or in electronic format. 


\section{A.2.0 Investigation Overview}

The CAI consisted of surface and subsurface soil screening, backhoe excavation, drilling, and collection of site characterization samples. Waste characterization samples were collected from septic tanks, a clean-out box, and associated piping. Inspections were performed on all associated septic system piping. The field investigation was conducted from July 22 through August 14, 2003. Sampling was conducted at step-out locations from November 7 through 8, 2003, with additional hand samples collected on December 1, 2003, and January 9, 2004. Additional waste characterization samples were collected from the contents of the septic tank at CAS 03-59-02 on January 16, 2004.

Field activities were performed in accordance with the approved site-specific health and safety plan (Shaw, 2003), which is consistent with the DOE Integrated Safety Management System. Samples were collected and field activities were documented following approved protocols and procedures indicated in the CAIP (NNSA/NSO, 2003). Quality control samples (i.e., field blanks, equipment rinsate blanks, source blanks, trip blanks, field duplicates, matrix spike duplicates) were collected as required by the Industrial Sites Quality Assurance Project Plan (NNSA/NV, 2002) following approved procedures. During the CAI, approved waste minimization procedures were followed, including segregation of industrial waste streams.

The CASs were characterized using combinations of surface and subsurface soil sampling, video mole investigation, and sampling for waste characterization. Surface soil samples were collected by hand and subsurface soil samples were collected using backhoe excavations and sonic drilling equipment. Investigation intervals and soil samples were field screened for VOCs, TPH, and radiological contaminants. To guide the investigations, the screening results were compared to FSLs. Select samples were shipped to an off-site laboratory to be analyzed for the chemical and radiological parameters identified in the CAIP. The contents of the septic tanks, clean-out box, and piping were sampled and analyzed for waste characterization purposes.

Except as noted in the CAS-specific sections of this appendix, CAU 516 sampling locations were accessible and sampling activities at planned locations were not restricted by buildings, storage areas, active operations, or aboveground and underground utilities. Step-out sampling locations were 
accessible and remained within anticipated spatial boundaries at all of the CASs. Weather conditions at the site varied to include rain, sun, intermittent cloudiness, and light to strong winds. Strong winds and storms occasionally delayed site operations.

Section A.2.1 through Section A.2.7 provide the investigation methodology, site geology and hydrology, and laboratory information. The CAS-specific investigation details are provided in Section A.3.0 through Section A.8.0.

\section{A.2.1 Preliminary Conceptual Model}

The results of the investigation activities confirmed the release mechanisms and pathways identified in the CSM used in the development of the DQOs presented in the CAIP (NNSA/NSO, 2003).

\section{A.2.2 Sample Locations}

Locations selected for sampling were based on interpretation of engineering drawings, information obtained during site visits, site history, and process knowledge provided in the CAIP. The planned sample locations are shown in the CAIP. Actual sample locations are shown in the figures presented in Section A.3.0 through Section A.8.0. Some locations were modified from planned positions due to field conditions and observations. In some cases, laboratory analytical results identified the need for step-out sampling. All sample locations were staked in the field, labeled appropriately, and surveyed with a GPS instrument. The locations have been plotted on site figures based on the coordinates collected by the GPS instrument, and what may appear as inaccuracies are due to the limited resolution of the technology. In addition to the sampling locations, the figures also show buildings and site-specific features. The GPS coordinates and figures are provided in Appendix D.

\section{A.2.3 Investigation Activities}

The investigation activities conducted at CAU 516 were based on the historical information, process knowledge, and visual observations discussed in the CAIP (NNSA/NSO, 2003). The technical approach consisted of Phase I and Phase II activities. The Phase I evaluation was used to determine if a release had occurred and if COCs were present at a CAS. If COCs were present, a Phase II 
(step-out sampling) evaluation was conducted to determine the extent of contamination. The following activities were completed to support Phase I and Phase II evaluation:

- Collected environmental soil samples for field screening and laboratory analyses to confirm the presence or absence of COPCs exceeding PALs (all CASs except 06-51-02 were sampled) - Phase I.

- Collected samples of septic tank contents to support waste characterization - Phase I.

- Identified CASs where COCs were present and collected additional environmental samples for laboratory analyses to define the vertical and lateral extent of contamination - Phase II.

- Collected QC samples for laboratory analyses to ensure that the data generated from the analysis of investigation samples met the requirements of the DQIs - Phase I and II.

- Collected additional samples, as necessary, to support waste characterization for the proper disposal of investigation-derived waste (IDW) - Phase I and II.

This investigation strategy allowed the nature and extent of contamination associated with each CAS to be established. Table A.2-1 lists the CAS-specific activities conducted during the CAI. The following sections describe the specific investigation activities that took place at CAU 516.

\section{A.2.3.1 Field Screening}

Field-screening activities for VOCs, TPH, and alpha and beta/gamma radiation were performed at all the CASs as specified in the CAIP except CAS 06-51-02. The debris identified for removal at CAS 03-51-02 was only screened for radioactivity to support disposal decisions. Field screening was conducted using a photoionization detector for VOCs. The FSL for VOCs was established at 20 ppm or 2.5 times background, whichever was greater. The site-specific FSLs for alpha and beta/gamma radiation were measured using a handheld alpha and beta/gamma radiological survey instrument. The radiological FSLs were established daily and defined as the mean background activity plus two times the standard deviation of readings from 10 background locations. The radiation FSLs are instrument-specific and were established daily for each instrument and CAS. The TPH FSL was established at $75 \mathrm{ppm}$ and screening was conducted using a SRI Gas Chromatograph. For health and safety and waste characterization purposes, septic tank media was sampled and analyzed on site for fecal coliform. 
Table A.2-1

Corrective Action Investigation Activities Conducted at CAU 516

\begin{tabular}{|c|c|c|c|c|c|c|}
\hline \multirow[b]{2}{*}{ Corrective Action Investigation Activities } & \multicolumn{6}{|c|}{ Corrective Action Site } \\
\hline & 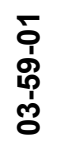 & 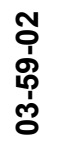 & $\begin{array}{l}5 \\
\frac{1}{10} \\
0 \\
0\end{array}$ & 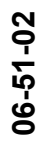 & 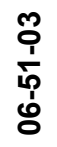 & 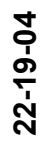 \\
\hline $\begin{array}{l}\text { Sampled and analyzed contents of septic system piping, if sufficient material was } \\
\text { present. }\end{array}$ & -- & -- & $\mathrm{X}$ & -- & $\mathrm{X}$ & -- \\
\hline Collected soil samples from biased sample locations. & $\mathrm{X}$ & $\mathrm{X}$ & $\mathrm{X}$ & -- & $\mathrm{X}$ & $\mathrm{X}$ \\
\hline Collected soil samples from step-out sample locations. & $\mathrm{X}$ & $\mathrm{X}$ & -- & -- & $\mathrm{X}$ & -- \\
\hline $\begin{array}{l}\text { Collected septic tank content samples for waste characterization purposes and } \\
\text { conducted on-site fecal coliform analysis. }\end{array}$ & $\mathrm{X}$ & $\mathrm{X}$ & -- & -- & -- & -- \\
\hline Collected geotechnical samples from native soil. & -- & $\mathrm{X}$ & -- & -- & -- & $\mathrm{X}$ \\
\hline $\begin{array}{l}\text { Field screened soil samples for volatile organic compounds, TPH, and alpha and } \\
\text { beta/gamma radiation. }\end{array}$ & $\mathrm{X}$ & $\mathrm{X}$ & $\mathrm{X}$ & -- & $\mathrm{X}$ & $\mathrm{X}$ \\
\hline Collected soil samples for waste characterization purposes. & -- & -- & -- & -- & $\mathrm{X}$ & -- \\
\hline Submitted select samples for off-site laboratory analysis. & $\mathrm{X}$ & $\mathrm{X}$ & $\mathrm{X}$ & -- & $\mathrm{X}$ & $\mathrm{X}$ \\
\hline $\begin{array}{l}\text { Field screened and removed surface debris (i.e., clay pipe, concrete) at } \\
\text { CAS 06-51-02. }\end{array}$ & -- & -- & -- & $X$ & -- & -- \\
\hline
\end{tabular}

-- Not applicable

The CAS-specific sections of this document identify where field screening was conducted and how the FSLs were used to define the extent of contamination. Field-screening results are recorded on sample collection logs that are retained in project files.

\section{A.2.3.2 Intrusive Investigation Activities}

Intrusive investigation activities, surface and subsurface sampling, were conducted at five CASs within CAU 516 to support Phase I and Phase II investigation activities. Soil samples were collected using "scoop and trowel" (surface hand-grab sampling), hand auger, backhoe, and sonic drilling equipment. The sample locations were initially surveyed for alpha and beta/gamma radiation prior to sampling. Additional screening was conducted during sample collection to guide the investigation and as a health and safety control to protect the sampling team. Labeled sample containers were filled according to the following sequence. Total VOCs and TPH-gasoline-range organics (GRO) sample containers were filled with soil directly from the surface location, backhoe bucket, or core barrel. This was followed by the collection of soil samples for VOC field screening using headspace analysis 
and for TPH field screening. Remaining soil was transferred into a stainless-steel bowl, homogenized, and screened for alpha and beta/gamma radiation and all the remaining sample containers were then filled. Excess soil was returned to its original location.

Surface soil samples were collected from 0.0 to $0.5 \mathrm{ft}$ bgs at biased locations focusing on stained soil, aboveground features, or areas with elevated radiological measurements. Subsurface soil samples were collected at depths that corresponded with the subsurface features or CAS component being investigated (e.g., septic tank). Additional sample intervals were collected and field screened until two consecutive samples with FSRs below FSLs were collected and the results recorded. If the field screening indicated that the FSRs were below FSLs, the additional samples were not collected and the soil was returned to the sampling location. At the discretion of the Site Supervisor, soil samples with FSRs exceeding FSLs were collected and submitted for off-site laboratory analysis.

\section{A.2.3.3 Waste Characterization}

Characterization of CAS-specific system components, objects, and materials was performed to support waste management decisions. System inspections were conducted using a variety of methods as appropriate for the CAS feature. Investigation methods included visual inspection and photodocumentation, video mole surveying, radiological surveys, and direct sampling and analyses of feature contents, if sufficient material was present. Waste characterization activities were intended to gather sufficient information and data about the CAS feature to support decisions regarding the proper disposal of materials located within each CAS.

\section{A.2.3.3.1 Visual Assessment}

The primary objective of the inspection process was to confirm that residual material was not present in the structure or, if present, to collect samples for analysis. Other objectives were to provide a qualitative description (e.g., volume, composition) of potential waste streams. Piping and other features associated with each CAS were inspected for breaches and residual material, where accessible. The contents of each opened structure were inspected, photographed, and observations were recorded in the FADL. A determination was made during the visual assessment as to whether there was sufficient material to sample. 


\section{A.2.3.3.2 Waste Characterization Sampling}

Waste characterization samples were collected of the solid and liquid material from septic tanks to support disposal of the contents during closure activities. Solid samples were collected from sediment that was filtered from the liquid. Liquid and solid samples were analyzed in accordance with the procedures specified in the CAIP. The specific analyses for each CAS are listed in CAS-specific sections and the analytical results are compared to the federal limits for hazardous waste, NDEP hydrocarbon action limits, and NTS landfill and lagoon acceptance criteria. When appropriate, the results were compared to the POC established for the NTS. The POCs have been established for NTS hazardous waste generators to ensure that all hazardous waste being shipped off site contains no "added radioactivity" (BN, 1995).

\section{A.2.4 Laboratory Analytical Information}

Chemical and radiological analyses were performed by Paragon Analytics, Inc. in Fort Collins, Colorado. The analytical parameters and laboratory analytical methods used to analyze investigation samples are listed in Table A.2-2. Organic and inorganic analytical results were compared to the minimum reporting levels (MRLs) established in Table 3-2 of the CAIP (NNSA/NSO, 2003) and reported in this appendix if they are detected at concentrations equal to or greater than the MRLs. Radiological analytical results are reported in this appendix if they are detected at concentrations equal to or greater than the MDCs.

Validated analytical data for CAU 516 investigation samples were compiled and evaluated to confirm the presence of contamination and define the extent of contamination, if present. The results for each CAS are presented in Section A.3.0 through Section A.8.0. The analytical results have been compared to MRLs/MDCs. Only those samples with concentrations equal to or greater than MRLs/MDCs are included in CAS-specific tables. The complete laboratory data packages are available in the project files.

The analytical parameters are CAS-specific and were selected through the application of site process knowledge according to the EPA's Guidance for the Data Quality Objectives Process (EPA, 1987). Samples collected during step-out sampling were only analyzed for the COPCs that exceeded PALs in the original samples. Bioassessment samples were not collected because FSRs and observations 
Table A.2-2

Laboratory Analytical Parameters and Methods for CAU 516 Investigation Samples

\begin{tabular}{|c|c|}
\hline Analytical Parameter & Analytical Method \\
\hline Total volatile organic compounds & Water $^{\mathrm{a}}$ and Soil ${ }^{\mathrm{a}}-\mathrm{SW}-846$ 8260B \\
\hline TCLP volatile organic compounds & Water $^{\mathrm{a}}$ - SW-846 1311 and 8260B \\
\hline Total semivolatile organic compounds (including hydroquinone) & Water $^{\mathrm{a}}$ and Soil ${ }^{\mathrm{a}}-\mathrm{SW}-8468270 \mathrm{C}$ \\
\hline TCLP semivolatile organic compounds & Water $^{a}$ - SW-846 1311 and $8270 \mathrm{C}$ \\
\hline Total petroleum hydrocarbons (gasoline-range organics) & Water $^{\mathrm{a}}$ and Soil ${ }^{\mathrm{a}}$ - SW-846 8015B (modified) \\
\hline Total petroleum hydrocarbons (diesel-range organics) & Water $^{\mathrm{a}}$ and Soil ${ }^{\mathrm{a}}$ - SW-846 8015B (modified) \\
\hline Total polychlorinated biphenyls & Water $^{\mathrm{a}}$ and Soil ${ }^{\mathrm{a}}$ - SW-846 8082 \\
\hline Total pesticides & Water $^{\mathrm{a}}$ and Soil ${ }^{\mathrm{a}}-\mathrm{SW}-8468081 \mathrm{~A}$ \\
\hline Total RCRA metals, plus aluminum and beryllium & $\begin{array}{l}\text { Water }^{\mathrm{a}} \text { - SW-846 6010B, 7470A } \\
\text { Soil }^{\mathrm{a}} \text { - SW-846 6010B, 7471A }\end{array}$ \\
\hline TCLP metals & Water $^{\mathrm{a}}$ - SW-846 1311, 6010B, and 7470A \\
\hline Gamma spectrometry & Water $^{\mathrm{b}}$ and Soil ${ }^{\mathrm{b}}$ - PAI 713R8 and 739R8 \\
\hline Isotopic uranium & $\begin{array}{l}\text { Water }{ }^{c} \text { and Soil }{ }^{\mathrm{C}} \text { - PAI 714R8, 721R10, 773R8, } \\
\text { 778R8, and 776R8 }\end{array}$ \\
\hline Isotopic plutonium & $\begin{array}{l}\text { Water }^{d} \text { and Soil } \\
\text { 778R8, } \text { and } 776 \mathrm{RAl} 8\end{array}$ \\
\hline Strontium-90 & Water $^{\mathrm{e}}$ and Solid ${ }^{\mathrm{e}}$ - PAI 724R8 and 707R7 \\
\hline Gross alpha/beta & Water $^{f}-\mathrm{PAI} 724 \mathrm{R} 8$ and 702R16 \\
\hline Tritium & Water $^{9}$ - PAI 704R6 and 700R9 \\
\hline
\end{tabular}

${ }^{a}$ EPA Test Methods for Evaluating Solid Waste, Physical/Chemical Methods, 3rd Edition, Parts 1-4, SW-846 (EPA, 1996).

${ }^{b}$ PAI Standard Operating Procedures (SOP) (PAI, 1999-2003) are a variant of and incorporate all the intentions of EPA

Procedure 901.1 and DOE/Environmental Measurements Laboratory Procedure 4.5.2.3.

${ }^{\mathrm{C}} \mathrm{PAI}$ SOPs (PAI, 1999-2003) are principally similar to the DOE/Environmental Measurements Laboratory Procedure U-2.

dPAI SOPs (PAI, 1999-2003) are principally similar to the DOE/EML procedures Pu-02 for soil and Pu-10 for water.

ePAI SOPs (PAI, 1999-2003) are principally similar to DOE/EML procedure Sr-02 for soil and similar to EPA procure 905.0 for water.

fPAI SOPs (PAI, 1999-2003) are principally similar to EPA Procedure 900.0.

'PAI SOPs (PAI, 1999-2003) are similar to EPA Procedure 906.0.

TCLP $=$ Toxicity Characteristic Leaching Procedure

did not indicate the need. Samples for geotechnical analysis were collected and archived. If needed, they can be analyzed to support corrective actions.

\section{A.2.5 Comparison to Preliminary Action Levels}

Chemicals and radionuclides detected in samples at concentrations greater than PALs were identified as COCs. If COCs were present, corrective action alternatives were considered for the CAS. The PALs for the CAU 516 investigation were identified and agreed to during the DQO process and as 
specified in ROTC No. 1 to the CAU 516 CAIP. For organic (except TPH) and most of the inorganic COPCs, the PALs are the EPA Region 9 PRGs (EPA, 2002). The PAL for TPH is 100 ppm action level per the NAC 445A.2272 (NAC, 2003).

Background concentrations for some metals have been used instead of PRGs when the natural background concentration exceeds the PRG, as is often the case with arsenic. For these metals, background is considered the mean plus two times the standard deviation for sediment samples collected by the Nevada Bureau of Mines and Geology throughout the Nevada Test and Training Range (formerly the Nellis Air Force Range) (NBMG, 1998; Moore, 1999).

Radionuclide concentrations measured in CAU 516 environmental samples were compared to isotope-specific PALs as presented in ROTC No. 1 to the CAIP (NNSA/NSO, 2003) and specified below:

- The PALs for radiological contaminants are based on the NCRP Report No. 129 recommended screening limits for construction, commercial, and industrial land use scenario (NCRP, 1999) scaled from 25- to 15-mrem per year dose and the generic guidelines for residual concentration of radionuclides in DOE Order 5400.5 (DOE, 1993).

- Potassium-40 (K-40) has been eliminated as a radionuclide COPC within the gamma spectrometry analysis due to its predominance in the environment, foods, and human tissue. In addition, the only mechanism for K-40 to be a COPC is through concentration. There are no reported activities at the NTS that would have concentrated K-40 or released it as a contaminant

Sample data that were equal to or greater than the MRLs were tabulated in the CAS-specific sections that follow. Results that are equal to or greater than PALs (a subset of those that exceed MRLs) are identified by bold text in the corresponding tables and discussed in Section A.3.0 through Section A.8.0. Nondetected results and results below MRLs have been excluded to minimize the size of this document. However, the unedited data set for CAU 516 is retained in an electronic format in the project files.

\section{A.2.6 Geology}

Regional native surface soil consists of poorly graded, moderately consolidated, alluvial silty sands with gravel and some cobble-sized volcanic detritus. Subsurface soil ranged from gravelly sands with 
fines to well-graded sands. The percentage of organic matter in the soil is low and decreases with depth beyond the native soil interface. Any modifications to the natural geology were documented on sample collection logs.

At CASs where leachfields, septic tanks, and sumps were present, the ground surface at the site has been disturbed either during or subsequent to the placement of the feature. A complete description of the regional geology for the NTS is provided in the CAIP (NNSA/NSO, 2003).

\section{A.2.7 Hydrology}

Hydrologic conditions beneath the CASs are less important to site characterization because of the depth to groundwater and the fact that the CAS features are close to the ground surface. The alluvium at the NTS is reported to reach depths of greater than 1,000 ft bgs (USGS, 1964). In Area 3, the depth to groundwater is estimated to be approximately 1,610 ft bgs (Wuellner, 1994). In Area 6, groundwater levels range from 535 to 2,315 ft bgs (DRI, 1993). The depth to groundwater in Area 22 is approximately $800 \mathrm{ft}$ bgs (Dodge, 1996).

Potential evapotranspiration at the NTS is significantly greater than precipitation, thus limiting vertical migration of contaminants. The annual average precipitation for this region is only 3 to 6 in. per year (USGS, 1975). The annual potential evapotranspiration at the Area 3 Radiological Waste Management Site has been estimated at 62.6 in. (Shott et.al., 1997). The potential annual evaporation is the dominant factor influencing the movement of water in the upper unsaturated zone. Therefore, recharge to groundwater from precipitation is not significant at the NTS and does not provide a significant mechanism for migration of contaminants to groundwater. Due to the depth to groundwater and climatic conditions, groundwater at the NTS Areas 3, 6, and 22 is not expected to have been impacted by vertical migration of detected contaminants. 


\section{A.3.0 CAS 03-59-01, Bldg 3C-36 Septic System}

Corrective Action Site 03-59-01 was part of the Area 3 Camp. Building 3C-36 was used as an office building until it was abandoned in 1992 and removed from the site in June 1998. The CAS consists of a septic tank, distribution box, leachfield, and associated piping that supported the operation of Building 3C-36. Additional details are provided in the CAIP (NNSA/NSO, 2003).

The septic system consists of the collection system piping that connects the drains at the former Building 3C-36 to the septic tank, the septic tank, the distribution box, and the leachfield piping. The collection system piping is approximately $100 \mathrm{ft}$ long. This piping begins at a clean-out on the north side about $5 \mathrm{ft}$ from the building foundation and includes the piping under the building foundation which is not part of this CAU. About $60 \mathrm{ft}$ south of the building foundation is the septic tank. About $10 \mathrm{ft}$ south of the septic tank is the distribution box. The leachfield has three runs of distribution piping, each approximately $55 \mathrm{ft}$ long. The collection system piping is 4-in. inside diameter plastic piping and the leachfield piping is 4-in. inside diameter perforated plastic. The septic tank is concrete with the outside dimensions of 10 by 8 by $5 \mathrm{ft}$ and is estimated to have a capacity of 3,000 gal. The distribution box is also made of concrete and is $3 \mathrm{ft}$ in diameter and $10 \mathrm{ft}$ deep.

\section{A.3.1 Corrective Action Investigation}

A total of 26 soil samples (including 2 duplicates) from 17 locations were collected during investigation activities conducted at CAS 03-59-01. Thirteen water samples and 1 soil (matrix spike $[\mathrm{MS}] /$ matrix spike duplicate [MSD]) sample were submitted for QC purposes. Two liquid samples were collected from the septic tank for waste characterization. When the liquid samples were initially collected, the samples appeared to be a liquid; however, when the samples arrived at the laboratory, the samples had separated into three phases; liquid, sludge, and sediment, increasing the total number of waste characterization samples to eight. All samples were analyzed for the parameters listed in Table A.3-1 (sample locations are shown in Figure A.3-1).

\section{A.3.1.1 Deviations}

There were no deviations from the investigation activities specified in the CAIP for CAS 03-59-01. 
Table A.3-1

Samples Collected at CAS 03-59-01

(Page 1 of 4 )

\begin{tabular}{|c|c|c|c|c|c|c|c|c|c|c|c|c|c|c|c|c|}
\hline \multirow[b]{2}{*}{$\begin{array}{l}\text { Sample } \\
\text { Location }\end{array}$} & \multirow[b]{2}{*}{$\begin{array}{l}\text { Sample } \\
\text { Number }\end{array}$} & \multirow[b]{2}{*}{$\begin{array}{c}\text { Depth } \\
\text { (ft bgs) }\end{array}$} & \multirow[b]{2}{*}{$\begin{array}{c}\text { Sample } \\
\text { Matrix }\end{array}$} & \multirow[b]{2}{*}{ Purpose } & \multicolumn{12}{|c|}{ Analysis } \\
\hline & & & & & 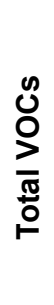 & $\begin{array}{l}0 \\
\text { O } \\
\frac{\pi}{\pi} \\
\frac{\pi}{0}\end{array}$ & 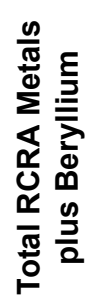 & $\begin{array}{c}0 \\
0 \\
0\end{array}$ & 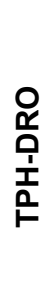 & 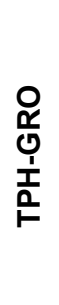 & 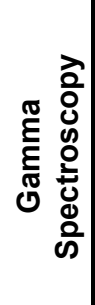 & 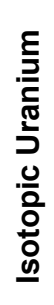 & 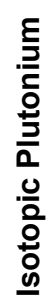 & 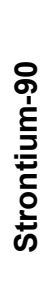 & 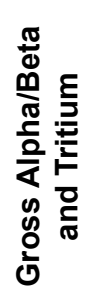 & 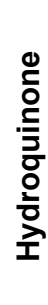 \\
\hline \multirow{3}{*}{$\mathrm{A} 01$} & 516A001 & $3-4$ & Soil & Environmental & $\bar{x}$ & $\mathrm{X}$ & $\mathrm{X}$ & $\bar{x}$ & $\mathrm{X}$ & $\mathrm{X}$ & $\bar{x}$ & -- & $\overline{--}$ & $\overline{--}$ & $\begin{array}{l}- \\
-\end{array}$ & $\overline{--}$ \\
\hline & 516A002 & $3-4$ & Soil & $\begin{array}{c}\text { Duplicate of } \\
516 \mathrm{~A} 001\end{array}$ & $x$ & $x$ & $x$ & $x$ & $x$ & $x$ & $x$ & -- & -- & -- & -- & -- \\
\hline & 516A017 & $10-11$ & Soil & Environmental & $x$ & $x$ & $x$ & $x$ & $x$ & $x$ & -- & -- & -- & -- & -- & -- \\
\hline \multirow{2}{*}{$\mathrm{A} 02$} & 516A003 & $3-4$ & Soil & Environmental & $X$ & $x$ & $X$ & $x$ & $x$ & $x$ & -- & -- & -- & -- & -- & -- \\
\hline & $516 \mathrm{~A} 018$ & $10-11$ & Soil & Environmental & $x$ & $x$ & $x$ & $x$ & $X$ & $x$ & -- & -- & -- & -- & -- & -- \\
\hline \multirow{2}{*}{$\mathrm{A} 03$} & 516A004 & $3-4$ & Soil & Environmental & $x$ & $X$ & $x$ & $x$ & $x$ & $x$ & $X$ & -- & - & -- & -- & -- \\
\hline & $516 \mathrm{~A} 016$ & $10-11$ & Soil & Environmental & $x$ & $x$ & $x$ & $x$ & $X$ & $x$ & -- & -- & -- & -- & -- & -- \\
\hline \multirow{2}{*}{ A04 } & 516A005 & $4-5$ & Soil & Environmental & $X$ & $X$ & $X$ & $x$ & $X$ & $x$ & -- & -- & -- & -- & -- & -- \\
\hline & $516 \mathrm{~A} 015$ & $10-11$ & Soil & Environmental & $X$ & $x$ & $x$ & $x$ & $X$ & $x$ & -- & -- & -- & -- & -- & -- \\
\hline A05 & 516A006 & $7-8$ & Soil & Environmental & $x$ & $x$ & $x$ & $x$ & $x$ & $x$ & $x$ & -- & - & -- & -- & -- \\
\hline \multirow{2}{*}{ A06 } & 516A007 & $8-9$ & Soil & Environmental & $x$ & $X$ & $x$ & $x$ & $X$ & $x$ & $X$ & -- & -- & -- & -- & -- \\
\hline & 516A026 & $14-15$ & Soil & Environmental & -- & -- & -- & -- & -- & -- & $x$ & -- & -- & -- & -- & -- \\
\hline $\mathrm{A} 06 \mathrm{~b}$ & $516 \mathrm{~A} 027$ & $16.5-17.5$ & Soil & Environmental & -- & -- & -- & -- & -- & -- & $x$ & -- & -- & -- & -- & -- \\
\hline A07 & $516 \mathrm{~A} 008$ & $8-9$ & Soil & Environmental & $x$ & $x$ & $x$ & $x$ & $x$ & $x$ & -- & -- & -- & -- & -- & -- \\
\hline $\mathrm{A} 08$ & 516A009 & $8-9$ & Soil & Environmental & $x$ & $x$ & $x$ & $x$ & $X$ & $x$ & -- & -- & -- & -- & -- & -- \\
\hline A09 & $516 \mathrm{~A} 010$ & $8-9$ & Soil & Environmental & $x$ & $x$ & $x$ & $x$ & $X$ & $x$ & -- & -- & - & -- & -- & -- \\
\hline
\end{tabular}


Table A.3-1

Samples Collected at CAS 03-59-01

(Page 2 of 4 )

\begin{tabular}{|c|c|c|c|c|c|c|c|c|c|c|c|c|c|c|c|c|}
\hline \multirow[b]{2}{*}{$\begin{array}{l}\text { Sample } \\
\text { Location }\end{array}$} & \multirow[b]{2}{*}{$\begin{array}{l}\text { Sample } \\
\text { Number }\end{array}$} & \multirow[b]{2}{*}{$\begin{array}{l}\text { Depth } \\
\text { (ft bgs) }\end{array}$} & \multirow[b]{2}{*}{$\begin{array}{l}\text { Sample } \\
\text { Matrix }\end{array}$} & \multirow[b]{2}{*}{ Purpose } & \multicolumn{12}{|c|}{ Analysis } \\
\hline & & & & & 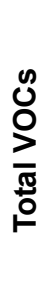 & 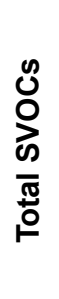 & 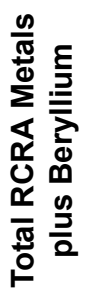 & $\begin{array}{c}\mathscr{n} \\
\text { 仓 } \\
0\end{array}$ & 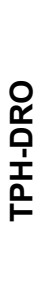 & 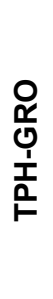 & 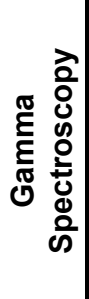 & 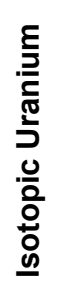 & \begin{tabular}{l}
$\frac{E}{3}$ \\
$\frac{\partial}{0}$ \\
$\frac{0}{3}$ \\
$\frac{1}{0}$ \\
.0 \\
\hdashline$\frac{0}{0}$ \\
$\frac{0}{0}$ \\
$\underline{0}$
\end{tabular} & 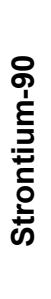 & 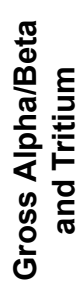 & 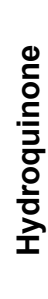 \\
\hline A10 & 516A011 & $8-9$ & Soil & Environmental & $\mathrm{X}$ & $\mathrm{X}$ & $\mathrm{X}$ & $\mathrm{X}$ & $\mathrm{X}$ & $\mathrm{X}$ & $\begin{array}{l}- \\
\text { - }\end{array}$ & -- & -- & -- & -- & -- \\
\hline A11 & 516A012 & $8-9$ & Soil & Environmental & $x$ & $x$ & $x$ & $x$ & $x$ & $x$ & -- & -- & -- & -- & -- & -- \\
\hline A12 & 516A013 & $8-9$ & Soil & Environmental & $x$ & $x$ & $X$ & $x$ & $x$ & $x$ & -- & -- & -- & -- & -- & -- \\
\hline A13 & 516A014 & $8-9$ & Soil & Environmental & $x$ & $x$ & $x$ & $x$ & $x$ & $x$ & -- & -- & -- & -- & -- & -- \\
\hline \multirow{2}{*}{ A14 } & 516A019 & $12.5-13.5$ & Soil & Environmental & -- & -- & -- & -- & -- & -- & $x$ & -- & -- & -- & -- & -- \\
\hline & 516A020 & $16-17$ & Soil & Environmental & -- & -- & -- & -- & -- & -- & $x$ & -- & -- & -- & -- & -- \\
\hline \multirow{3}{*}{ A15 } & 516A021 & $12.5-13.5$ & Soil & Environmental & -- & -- & -- & -- & -- & -- & $X$ & -- & -- & -- & -- & -- \\
\hline & 516A022 & $16-17$ & Soil & Environmental & -- & -- & -- & -- & -- & -- & $x$ & -- & -- & -- & -- & -- \\
\hline & 516A023 & $16-17$ & Soil & $\begin{array}{c}\text { Duplicate of } \\
516 A 022\end{array}$ & -- & -- & -- & -- & -- & -- & $x$ & -- & -- & -- & -- & -- \\
\hline A16 & 516A024 & $12.5-13.5$ & Soil & Environmental & -- & -- & -- & -- & -- & -- & $x$ & -- & -- & -- & -- & -- \\
\hline
\end{tabular}


Table A.3-1

Samples Collected at CAS 03-59-01

(Page 3 of 4 )

\begin{tabular}{|c|c|c|c|c|c|c|c|c|c|c|c|c|c|c|c|c|}
\hline \multirow[b]{2}{*}{$\begin{array}{l}\text { Sample } \\
\text { Location }\end{array}$} & \multirow[b]{2}{*}{$\begin{array}{l}\text { Sample } \\
\text { Number }\end{array}$} & \multirow[b]{2}{*}{$\begin{array}{l}\text { Depth } \\
\text { (ft bgs) }\end{array}$} & \multirow[b]{2}{*}{$\begin{array}{l}\text { Sample } \\
\text { Matrix }\end{array}$} & \multirow[b]{2}{*}{ Purpose } & \multicolumn{12}{|c|}{ Analysis } \\
\hline & & & & & 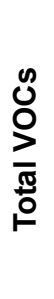 & 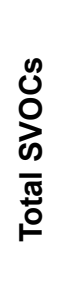 & 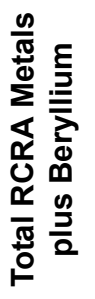 & 品 & 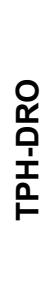 & $\begin{array}{l}\text { O } \\
\frac{1}{0} \\
\text { 1 } \\
\frac{1}{1} \\
\qquad\end{array}$ & 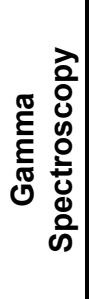 & 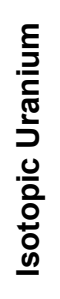 & \begin{tabular}{l}
$\frac{E}{3}$ \\
$\frac{\partial}{0}$ \\
$\frac{0}{J}$ \\
$\frac{1}{0}$ \\
.0 \\
\hdashline$\frac{0}{0}$ \\
$\frac{0}{0}$ \\
$\underline{0}$
\end{tabular} & 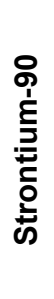 & 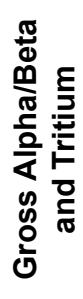 & 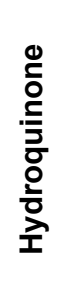 \\
\hline \multirow{4}{*}{$\begin{array}{c}\text { Septic } \\
\text { Tank } \\
\text { Effluent } \\
\text { Chamber }\end{array}$} & $516 \mathrm{~A} 501^{\mathrm{a}}$ & NA & Liquid & $\begin{array}{c}\text { Waste } \\
\text { Characterization }\end{array}$ & $x$ & -- & -- & $x$ & -- & $x$ & -- & -- & -- & -- & -- & -- \\
\hline & $516 A 501 L^{a}$ & NA & Liquid & $\begin{array}{c}\text { Waste } \\
\text { Characterization }\end{array}$ & -- & $x$ & $x$ & $x$ & $x$ & -- & -- & -- & -- & -- & -- & -- \\
\hline & 516A501S ${ }^{a}$ & NA & Sediment & $\begin{array}{c}\text { Waste } \\
\text { Characterization }\end{array}$ & -- & $x$ & $X$ & $x$ & $x$ & -- & $x$ & -- & -- & -- & -- & -- \\
\hline & $516 \mathrm{~A} 501 \mathrm{SL}^{\mathrm{a}}$ & NA & Sludge & $\begin{array}{c}\text { Waste } \\
\text { Characterization }\end{array}$ & -- & -- & -- & -- & -- & -- & $x$ & -- & -- & -- & $x$ & -- \\
\hline \multirow{4}{*}{$\begin{array}{c}\text { Septic } \\
\text { Tank - } \\
\text { Influent } \\
\text { Chamber }\end{array}$} & $516 A 502^{a}$ & NA & Liquid & $\begin{array}{c}\text { Waste } \\
\text { Characterization }\end{array}$ & $x$ & -- & -- & $x$ & -- & $x$ & -- & -- & -- & -- & -- & -- \\
\hline & $516 \mathrm{~A} 502 \mathrm{~L}^{\mathrm{a}}$ & NA & Liquid & $\begin{array}{c}\text { Waste } \\
\text { Characterization }\end{array}$ & -- & $x$ & $x$ & $x$ & $x$ & -- & $x$ & -- & -- & -- & -- & -- \\
\hline & $516 A 502 S^{a}$ & NA & Sediment & $\begin{array}{c}\text { Waste } \\
\text { Characterization }\end{array}$ & -- & $x$ & $X$ & $x$ & $x$ & -- & -- & -- & -- & -- & -- & -- \\
\hline & 516A502SL ${ }^{a}$ & NA & Sludge & $\begin{array}{c}\text { Waste } \\
\text { Characterization }\end{array}$ & -- & -- & -- & -- & -- & -- & $x$ & -- & -- & -- & $x$ & -- \\
\hline A16 & 516A025 & $16-17$ & Soil & MS/MSD & -- & -- & -- & -- & -- & -- & $x$ & -- & -- & -- & -- & -- \\
\hline \multirow{2}{*}{ NA } & 516A301 & NA & Water & Trip Blank & $x$ & -- & -- & -- & -- & -- & -- & -- & -- & -- & -- & -- \\
\hline & 516A302 & NA & Water & Trip Blank & $x$ & -- & -- & -- & -- & -- & -- & -- & -- & -- & -- & -- \\
\hline
\end{tabular}


Table A.3-1

Samples Collected at CAS 03-59-01

(Page 4 of 4 )

\begin{tabular}{|c|c|c|c|c|c|c|c|c|c|c|c|c|c|c|c|c|}
\hline \multirow[b]{2}{*}{$\begin{array}{l}\text { Sample } \\
\text { Location }\end{array}$} & \multirow[b]{2}{*}{$\begin{array}{l}\text { Sample } \\
\text { Number }\end{array}$} & \multirow[b]{2}{*}{$\begin{array}{l}\text { Depth } \\
\text { (ft bgs) }\end{array}$} & \multirow[b]{2}{*}{$\begin{array}{l}\text { Sample } \\
\text { Matrix }\end{array}$} & \multirow[b]{2}{*}{ Purpose } & \multicolumn{12}{|c|}{ Analysis } \\
\hline & & & & & 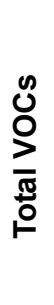 & 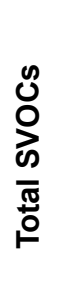 & 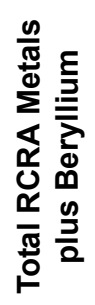 & 品 & 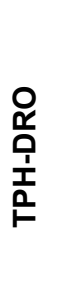 & $\begin{array}{l}\text { O } \\
\text { ớ } \\
\text { İ } \\
\text { T } \\
\text { R }\end{array}$ & 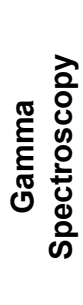 & 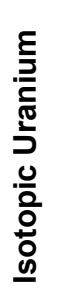 & 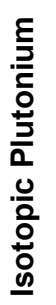 & 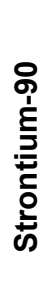 & 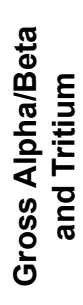 & 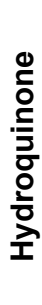 \\
\hline \multirow{11}{*}{ NA } & 516A303 & NA & Water & Trip Blank & $\mathrm{X}$ & -- & -- & $\overline{--}$ & -- & -- & -- & $\begin{array}{l}- \\
-\end{array}$ & $\begin{array}{l}- \\
-\end{array}$ & -- & -- & $\overline{--}$ \\
\hline & 516A305 & NA & Water & Trip Blank & $x$ & -- & -- & -- & -- & -- & -- & -- & -- & -- & -- & -- \\
\hline & 516A307 & NA & Water & Trip Blank & $x$ & -- & -- & -- & -- & -- & -- & -- & -- & -- & -- & -- \\
\hline & 516A308 & NA & Water & Trip Blank & $x$ & -- & -- & -- & -- & -- & -- & -- & -- & -- & -- & -- \\
\hline & 516A309 & NA & Water & Trip Blank & $x$ & -- & -- & -- & -- & -- & -- & -- & -- & -- & -- & -- \\
\hline & $516 A 311$ & NA & Water & Trip Blank & $X$ & -- & -- & -- & -- & -- & -- & -- & -- & -- & -- & -- \\
\hline & 516A306 & NA & Water & Field Blank & $x$ & $x$ & $x$ & $x$ & $x$ & $x$ & $x$ & -- & $x$ & $x$ & -- & -- \\
\hline & 516A312 & NA & Water & Field Blank & -- & -- & -- & -- & -- & -- & $x$ & -- & -- & -- & -- & -- \\
\hline & 516A304 & $\mathrm{NA}$ & Water & Source Blank & $x$ & $x$ & $x$ & $x$ & $x$ & $x$ & $x$ & $x$ & $x$ & $x$ & $x$ & $x$ \\
\hline & 516A310 & NA & Water & Source Blank & $x$ & $X$ & $x$ & $x$ & $x$ & $X$ & $X$ & $X$ & $X$ & $x$ & $X$ & -- \\
\hline & 516A314 & NA & Water & Source Blank & -- & -- & -- & -- & -- & -- & $x$ & -- & $x$ & -- & -- & -- \\
\hline
\end{tabular}

aSample split into liquid, sediment, and sludge samples by the laboratory and analyzed separately.

\section{$\mathrm{L}=$ Liquid}

NA $=$ Not applicable

$\mathrm{SL}=$ Sludge

$S=$ Sediment

-- = Not analyzed

$\mathrm{PCB}=$ Polychlorinated biphenyls 


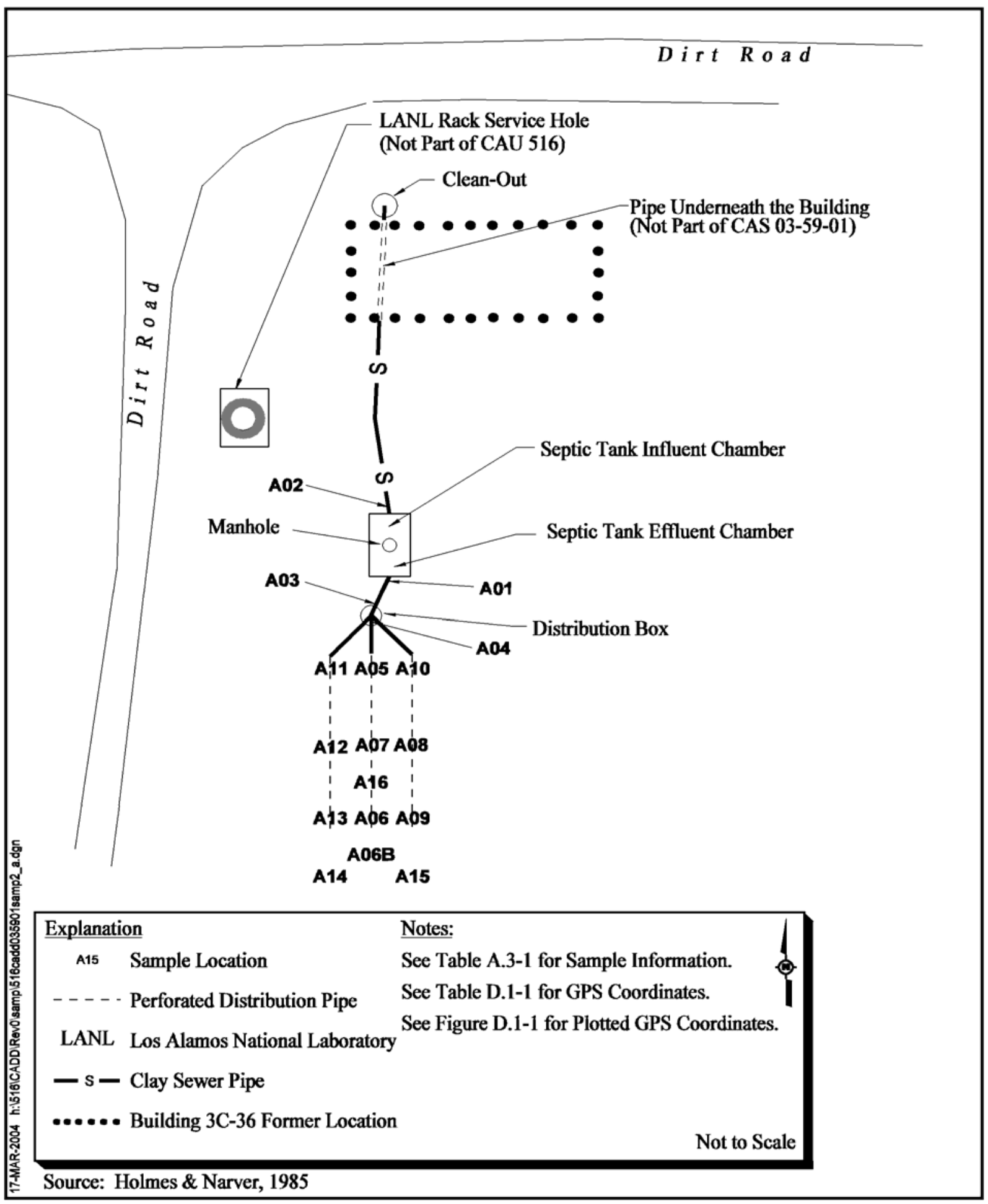

Figure A.3-1

CAU 516, CAS 03-59-01, Bldg 3C-36 Septic System, Sample Locations 


\section{A.3.2 Investigation Activities}

The following sections provide descriptions of the CAS-specific activities conducted to complete Phase I and Phase II activities as outlined in the CAIP and are listed in Table A.2-1.

\section{A.3.2.1 Field Screening}

Soil samples were screened for VOCs, TPH, and alpha and beta/gamma radiation. The FSRs were compared to FSLs to guide subsequent sampling and analytical decisions. The VOC FSL was established at $20 \mathrm{ppm}$. The TPH FSL was established at $75 \mathrm{ppm}$. The FSLs less than $75 \mathrm{ppm}$ are considered to be below the action level of $100 \mathrm{ppm}$ (NAC, 2003).

The radiological FSL for alpha radiation was established daily and ranged between 32.6 and 76 disintegrations per minute $(\mathrm{dpm}) / 100$ square centimeters $\left(\mathrm{cm}^{2}\right)$. The beta/gamma FSL was established daily and ranged between 1,783 and $1,983 \mathrm{dpm} / 100 \mathrm{~cm}^{2}$.

Media from both septic tank chambers were screened for fecal coliform. All results were negative. The VOC, TPH, and radiological FSLs in soil samples were not exceeded during sampling activities at this CAS.

\section{A.3.2.2 Intrusive Investigation Activities}

This section discusses the intrusive sampling that was conducted at CAS 03-59-02.

\section{A.3.2.2.1 Initial Sampling}

Initial sampling activities included the collection of soil samples from below the influent and effluent pipes of the septic tank and the distribution box as well as at the base of the tank and distribution box as outlined in the CAIP (NNSA/NSO, 2003). Twelve samples were also taken at the interface of the leachfield material and the native soil. All samples were collected with a backhoe. Two liquid waste characterization samples were collected from the septic tank (one from the influent chamber and one from the effluent chamber). The evaluation of the waste characterization samples are discussed in Section A.3.1. 


\section{A.3.2.2.2 Step-out Sampling}

Location A06 was identified from the Phase I sampling activities as a location of concern due to the presence of americium (Am)-241 at a concentration $(0.99 \pm 0.04 \mathrm{pCi} / \mathrm{g})$ exceeding the PAL of $2.0 \mathrm{pCi} / \mathrm{g}$ in affect prior to the approval of ROTC No. 1 to the CAIP. To define the extent of contamination, the field crew returned to this CAS on November 7 and 8, 2003, to conduct step-out sampling. Two vertical samples were collected between 12.5 and $13.5 \mathrm{ft}$ bgs, and 16.0 and $17.0 \mathrm{ft}$ bgs at each of four step-out locations (A09, A13, A14, and A15) around location A06 (Figure A.3-1). These samples were analyzed for gamma-emitting radionuclides. The analytical results were less than the PALs in effect at the time. The ROTC No. 1 to the CAIP changed the PAL for Am-241 in soil from 0.05 to $7.62 \mathrm{pCi} / \mathrm{g}$ (NCRP, 1999). Consequently, a reevalutation of the initial analytical results indicate that $\mathrm{Am}-241$ is not a COC.

\section{A.3.2.3 Waste Characterization}

Waste characterization activities conducted at CAS 03-59-01 included visual assessments (e.g., video mole survey), radiological survey, photodocumentation, and collecting waste characterization samples from the septic tank. The following sections discuss the waste characterization activities.

\section{A.3.2.3.1 Visual Assessment}

All of the septic system piping with the exception of about $25 \mathrm{ft}$ between the clean-out and the septic tank was visually inspected using video equipment. A video mole survey revealed that the pipe was clean and dry except for some rocks in the pipe adjacent to the building foundation and some moisture between the distribution box and the septic tank. The pipe was only damp and there was not sufficient free liquid to sample. No breaks in the pipe or obvious release of contaminants were observed during the video inspection. The section of pipe could not be inspected because rocks prevented the advancement of the camera.

Samples were collected beneath the pipes entering and exiting the septic tank and the distribution box, and also from the soil horizon beneath the septic tank and distribution box. No breaks in the pipes or obvious release of contaminants were observed during the excavations around these features. 


\section{A.3.2.3.2 Waste Characterization Sampling}

The septic tank has approximately $4 \mathrm{ft}$ of liquid and solids in the influent and effluent chambers of the tank, which are separated by a baffle. Both chambers of the tank could be accessed from one manhole and were sampled for waste characterization purposes. One liquid sample was collected from each chamber of the tank. When initially collected, the samples appeared to be a liquid; however, when the samples had arrived to the laboratory, the samples had separated into three phases (liquid, sludge, and sediment). The laboratory separated each sample (i.e., 516A501 and 516A502) into the three phases and analyzed each phase and assigned a unique sample identifier (i.e., 516A501L, 516A501S, 516A501SL, 516A502L, 516A502S, 516A502SL).

The contents of the distribution box were not sampled as visual inspection revealed that there was an inadequate volume of liquid for sample collection and analysis.

\section{A.3.2.4 Sample Analysis}

Investigation samples were analyzed for the CAIP-specified COPCs including VOCs, semivolatile organic compounds (SVOCs), RCRA metals, beryllium, TPH (DRO/GRO), polychlorinated biphenyls (PCBs), isotopic $\mathrm{Pu}$, strontium (Sr)-90, and gamma-emitting radionuclides. Waste characterization samples were analyzed for VOCs, SVOCs, RCRA metals, beryllium, TPH (DRO/GRO), PCBs, gross alpha/beta, tritium, and gamma-emitting radionuclides. The analytical parameters and laboratory methods used to analyze the investigation samples are listed in Table A.2-2. Table A.3-1 lists the specific analytical suite for CAS 03-59-01.

\section{A.3.3 Analytes Detected Above Minimum Reporting Limits or Minimum Detectable Concentrations}

Analytical results from the soil samples with concentrations equal to or greater than the MRL (NNSA/NSO, 2003) are summarized in the following sections. These results were compared to the nonradiological PALs identified in the CAIP and the radiological PALs identified in the ROTC No. 1 to the CAIP. These values are a subset of the results that are equal to or greater than MRLs. Results equal to or greater than PALs are identified by bold text in the analytical tables. The complete data set is maintained in the project file as hard copy and in electronic format. 


\section{A.3.3.1 Total Volatile Organic Compound Analytical Results for Soil Samples}

Total VOC analytical results for soil samples equal to or greater than the MRLs are reported in Table A.3-2. The concentration of methylene chloride is less than the PAL.

Table A.3-2

Soil Sample Results for Total VOCs Equal to or Greater than Minimum Reporting Limits at CAS 03-59-01

\begin{tabular}{|c|c|c|c|}
\hline $\begin{array}{c}\text { Sample } \\
\text { Location }\end{array}$ & $\begin{array}{c}\text { Sample } \\
\text { Number }\end{array}$ & $\begin{array}{c}\text { Depth } \\
\text { (ft bgs) }\end{array}$ & Contaminants of Potential Concern $(\mu \mathrm{g} / \mathrm{kg})$ \\
\cline { 2 - 4 } & \multicolumn{2}{|c|}{ Preliminary Action Levels ${ }^{\mathrm{a}}$} & $\mathbf{2 1 , 0 0 0}$ \\
\hline \hline $\mathrm{A} 06$ & $516 \mathrm{~A} 007$ & $8-9$ & $13(\mathrm{~B})$ \\
\hline
\end{tabular}

aU.S. Environmental Protection Agency, Region 9 Preliminary Remediation Goals (PRGs) (EPA, 2002)

$B=$ Analyte found in the sample and associated blank.

$\mathrm{ft}$ bgs $=$ Feet below ground surface

$\mu \mathrm{g} / \mathrm{kg}=$ Micrograms per kilogram

\section{A.3.3.2 Total Semivolatile Organic Compound Analytical Results for Soil Samples}

Total SVOC analytical results for soil samples equal to or greater than the MRLs are reported in Table A.3-3. The concentrations of the two SVOCs were less than the PALs.

Table A.3-3

Soil Sample Results for Total SVOCs Equal to or Greater than Minimum Reporting Limits at CAS 03-59-01

\begin{tabular}{|c|c|c|c|c|}
\hline \multirow{2}{*}{$\begin{array}{c}\text { Sample } \\
\text { Location }\end{array}$} & \multirow{2}{*}{$\begin{array}{c}\text { Sample } \\
\text { Number }\end{array}$} & $\begin{array}{c}\text { Depth } \\
\text { (ft bgs) }\end{array}$ & Bis(2-Ethylhexyl)Phthalate & Di-N-Butyl Phthalate \\
\cline { 3 - 5 } & & & 120,000 & $62,000,000$ \\
\hline \multicolumn{2}{|c|}{ Preliminary Action Levels ${ }^{\mathrm{a}}$} & -- & 570 \\
\hline \hline \multirow{2}{*}{$\mathrm{A} 04$} & $516 \mathrm{~A} 005$ & $4-5$ & 640 & -- \\
\cline { 2 - 5 } & $516 \mathrm{~A} 015$ & $10-11$ & & \\
\hline
\end{tabular}

aU.S. Environmental Protection Agency, Region 9 Preliminary Remediation Goals (PRGs) (EPA, 2002)

$\mathrm{ft}$ bgs $=$ Feet below ground surface

$\mu \mathrm{g} / \mathrm{kg}=$ Micrograms per kilogram

$--=$ Not detected at a concentration equal to or greater than the minimum reporting limits 


\section{A.3.3.3 Total RCRA Metal Analytical Results for Soil Samples}

The analytical results for total RCRA metals, including beryllium, that are equal to or greater than the MRLs are reported in Table A.3-4. The concentrations of the total RCRA metals and beryllium were less than the PALs.

\section{A.3.3.4 Total Petroleum Hydrocarbon Analytical Results for Soil Samples}

Total petroleum hydrocarbon analytical results equal to or greater than the MRLs are reported in Table A.3-5. The single reported TPH-DRO concentration is less than the PAL.

\section{A.3.3.5 Polychlorinated Biphenyl Analytical Results for Soil Samples}

Polychlorinated biphenyls were not detected at concentrations equal to or greater than the MRLs.

\section{A.3.3.6 Gamma Spectroscopy Analytical Results for Soil Samples}

Gamma spectroscopy analytical results for soil samples equal to or exceeding MDCs are shown in Table A.3-6. Gamma spectroscopy concentrations were less than the PALs.

\section{A.3.3.7 Isotopic Plutonium Analytical Results for Soil Samples}

Isotopic plutonium was not detected at concentrations that were equal to or greater than the MDCs.

\section{A.3.3.8 Strontium-90 Analytical Results for Soil Samples}

Strontium-90 was not detected at concentrations that were equal to or greater than the MDCs.

\section{A.3.4 Waste Characterization Analytical Results}

The analytical results from the septic tank samples equal to or greater than the MRLs are presented in Table A.3-7. Two liquid samples were collected from inside the septic tank (one from the effluent chamber [516A501] and one from the influent chamber [516A502]). The samples were analyzed for VOCs, SVOCs, RCRA metals, beryllium, TPH (DRO/GRO), PCBs, gamma-emitting radionuclides, gross alpha and gross beta, and tritium. The TPH-DRO septic tank results of 7,800 (516A501S) and 


\section{Table A.3-4 \\ Soil Sample Results for Total Metals Detected Equal to or Greater than Minimum Reporting Limits at CAS 03-59-01}

\begin{tabular}{|c|c|c|c|c|c|c|c|c|c|}
\hline \multirow[b]{2}{*}{$\begin{array}{l}\text { Sample } \\
\text { Location }\end{array}$} & \multirow[b]{2}{*}{$\begin{array}{l}\text { Sample } \\
\text { Number }\end{array}$} & \multirow[b]{2}{*}{$\begin{array}{c}\text { Depth } \\
\text { (ft bgs) }\end{array}$} & \multicolumn{7}{|c|}{ Contaminants of Potential Concern (mg/kg) } \\
\hline & & & 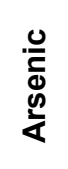 & 点 & 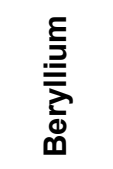 & 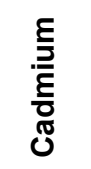 & 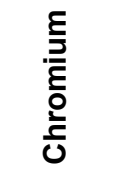 & ర్ర్త & 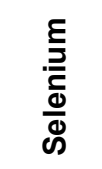 \\
\hline \multicolumn{3}{|c|}{ Preliminary Action Levels } & $23^{a}$ & $67,000^{b}$ & $1,900^{b}$ & $450^{b}$ & $450^{b}$ & $750^{b}$ & $5,100^{b}$ \\
\hline \multirow{2}{*}{$\mathrm{A} 01$} & $516 A 001$ & $3-4$ & 6.3 & 270 & 0.8 & -- & $6.8(J)^{\mathrm{c}}$ & $8.6(J)^{d}$ & 0.86 \\
\hline & 516A002 & $3-4$ & 6.6 & 280 & 0.85 & -- & $6.9(\mathrm{~J})^{\mathrm{c}}$ & $10(\mathrm{~J})^{\mathrm{d}}$ & 0.8 \\
\hline $\mathrm{A} 02$ & 516A003 & $3-4$ & 6.3 & 300 & 0.79 & -- & $7.1(\mathrm{~J})^{\mathrm{c}}$ & $9.5(J)^{d}$ & 0.93 \\
\hline $\mathrm{A} 03$ & $516 \mathrm{~A} 004$ & $3-4$ & 6.4 & 270 & 0.77 & -- & $6.6(\mathrm{~J})^{\mathrm{c}}$ & $9(J)^{d}$ & 0.63 \\
\hline $\mathrm{A} 04$ & 516A005 & $4-5$ & 5.5 & 160 & 0.94 & -- & $7(\mathrm{~J})^{\mathrm{c}}$ & $10(\mathrm{~J})^{\mathrm{d}}$ & -- \\
\hline A05 & 516A006 & $7-8$ & 3.8 & 150 & 0.96 & -- & $6.5(J)^{c}$ & $9.8(J)^{d}$ & -- \\
\hline A06 & 516A007 & $8-9$ & 5.2 & 150 & 1.1 & -- & $7.6(J)^{c}$ & $12(\mathrm{~J})^{\mathrm{d}}$ & -- \\
\hline $\mathrm{A} 07$ & 516A008 & $8-9$ & 3.4 & 110 & 0.84 & -- & $5.6(J)^{c}$ & $9.3(J)^{d}$ & -- \\
\hline A08 & 516A009 & $8-9$ & 5 & 160 & 0.81 & -- & $7.2(J)^{c}$ & $11(\mathrm{~J})^{\mathrm{d}}$ & 0.57 \\
\hline A09 & $516 \mathrm{~A} 010$ & $8-9$ & 5.3 & 180 & 0.96 & -- & $7.2(J)^{c}$ & $11(\mathrm{~J})^{\mathrm{d}}$ & -- \\
\hline A10 & $516 \mathrm{~A} 011$ & $8-9$ & 6.1 & 150 & 1 & -- & $7.7(\mathrm{~J})^{\mathrm{c}}$ & $13(\mathrm{~J})^{d}$ & 0.55 \\
\hline A11 & 516A012 & $8-9$ & 5.1 & 160 & 0.93 & -- & $7.5(\mathrm{~J})^{\mathrm{c}}$ & $11(\mathrm{~J})^{\mathrm{d}}$ & -- \\
\hline $\mathrm{A} 12$ & $516 \mathrm{~A} 013$ & $8-9$ & 4.6 & 140 & 0.85 & -- & $6.6(J)^{c}$ & $11(J)^{d}$ & -- \\
\hline A13 & $516 \mathrm{~A} 014$ & $8-9$ & 8.1 & 170 & 1.2 & 0.75 & $9(J)^{c}$ & $12(\mathrm{~J})^{\mathrm{d}}$ & 0.75 \\
\hline A14 & 516A015 & $10-11$ & 3.8 & 160 & 0.91 & -- & 6 & 9 & -- \\
\hline A15 & 516A016 & $10-11$ & 4.9 & 180 & 1 & -- & 7.5 & 11 & -- \\
\hline A16 & 516A017 & $10-11$ & 6.7 & 160 & 1 & -- & 8.2 & 12 & -- \\
\hline $\mathrm{A} 17$ & 516A018 & 10- 11 & 4.2 & 180 & 0.84 & -- & 6.9 & 12 & -- \\
\hline
\end{tabular}

aBased on the background concentrations for metals. Background is considered the mean plus two times the standard deviation for sediment samples collected by the Nevada Bureau of Mines and Geology throughout the Nevada Test and Training Range (NBMG, 1998; Moore, 1999).

bU.S. Environmental Protection Agency, Region 9 Preliminary Remediation Goals (PRGs) (EPA, 2002)

'Serial dilution \%D outside control limits. Matrix effects may exist.

${ }^{\mathrm{d}}$ Serial dilution \%D outside control limits. Duplicate precision analysis (relative percent difference) outside control limits. Matrix effects may exist.

$\mathrm{ft}$ bgs $=$ Feet below ground surface

$\mathrm{mg} / \mathrm{kg}=$ Milligrams per kilogram

$--=$ Not detected at concentrations equal to or greater than the minimum reporting limits

$\mathrm{J}=$ Estimated value 
Table A.3-5

Soil Sample Results for Total Petroleum Hydrocarbons

Equal to or Greater than Minimum Reporting Limits at CAS 03-59-01

\begin{tabular}{||c|c|c|c||}
\hline $\begin{array}{c}\text { Sample } \\
\text { Location }\end{array}$ & $\begin{array}{c}\text { Sample } \\
\text { Number }\end{array}$ & $\begin{array}{c}\text { Depth } \\
\text { (ft bgs) }\end{array}$ & Contaminants of Potential Concern (mg/kg) \\
\hline \multicolumn{3}{|c||}{ Preliminary Action Levels } & 100 \\
\hline \hline A01 & $516 \mathrm{~A} 001$ & $3-4$ & $11(\mathrm{H})$ \\
\hline
\end{tabular}

aU.S. Environmental Protection Agency, Region 9 Preliminary Remediation Goals (PRGs) (EPA, 2002)

$\mathrm{H}=$ Fuel pattern is in the heavier end of the retention time window.

$\mathrm{ft}$ bgs $=$ Feet below ground surface

$\mathrm{mg} / \mathrm{kg}=$ Milligrams per kilogram

-- = Not detected at concentrations equal to or greater than minimum reporting limits

$3,600 \mathrm{mg} / \mathrm{kg}$ (516A502S) exceed the TPH action level of $100 \mathrm{ppm}$ (NAC, 2002), requiring the contents to be disposed of as hazardous waste.

\section{A.3.5 Contaminants of Concern}

No COCs are present in the soil at CAS 03-59-01. There were no radiological COPCs identified in the soil that exceeded unrestricted release criteria. The septic tank contents will be removed and disposed of as hydrocarbon waste.

\section{A.3.6 Nature and Extent of Contamination}

All contamination materials at CAS 03-59-01 are contained within the septic tank. The contents will be removed during corrective action activities prior to closure.

\section{A.3.7 Revised Conceptual Site Model}

No variations to the conceptual site model were identified. 
Table A.3-6

Soil Sample Results for Gamma-Emitting Radionuclides

Equal to or Greater than Minimum Detectable Concentrations at CAS 03-59-01

\begin{tabular}{|c|c|c|c|c|c|c|c|c|c|}
\hline \multirow[b]{2}{*}{$\begin{array}{l}\text { Sample } \\
\text { Location }\end{array}$} & \multirow[b]{2}{*}{$\begin{array}{l}\text { Sample } \\
\text { Number }\end{array}$} & \multirow[b]{2}{*}{$\begin{array}{l}\text { Depth } \\
\text { (ft bgs) }\end{array}$} & \multicolumn{7}{|c|}{ Contaminants of Potential Concern (pCi/g) } \\
\hline & & & 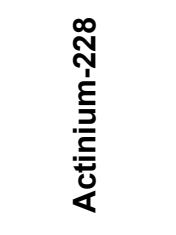 & 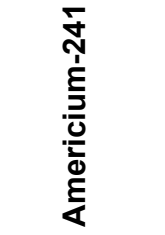 & 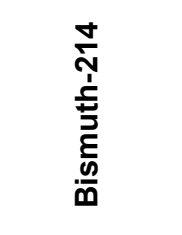 & 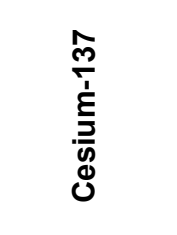 & 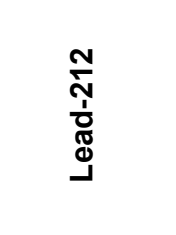 & 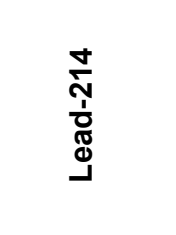 & 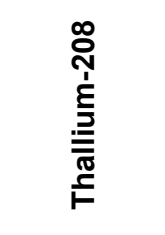 \\
\hline \multicolumn{3}{|c|}{ Preliminary Action Levels } & $15^{\mathrm{a}}$ & $7.62^{\mathrm{b}}$ & $15^{\mathrm{a}}$ & $7.30^{\mathrm{b}}$ & $15^{\mathrm{a}}$ & $15^{\mathrm{a}}$ & $15^{\mathrm{a}}$ \\
\hline \multirow{2}{*}{ A01 } & 516A001 & $3-4$ & $\overline{--}$ & -- & $\overline{--}$ & -- & $1.36 \pm 0.4$ & $1.08 \pm 0.35$ & -- \\
\hline & 516A002 & $3-4$ & -- & -- & $0.99 \pm 0.42$ & -- & $1.34 \pm 0.37$ & $1.21 \pm 0.36$ & -- \\
\hline A03 & 516A004 & $3-4$ & $1.86 \pm 0.62$ & $\begin{array}{l}- \\
-\end{array}$ & $1.27 \pm 0.44$ & -- & $1.23 \pm 0.35$ & $1.15 \pm 0.32$ & $0.4 \pm 0.18$ \\
\hline A05 & $516 \mathrm{~A} 006$ & $7-8$ & $1.76 \pm 0.7$ & -- & -- & -- & $1.58 \pm 0.44$ & $1.02 \pm 0.35$ & $0.62 \pm 0.26$ \\
\hline \multirow{2}{*}{ A06 } & $516 \mathrm{~A} 007$ & $8-9$ & $1.65 \pm 0.51$ & $0.99 \pm 0.4$ & -- & $2.06 \pm 0.41$ & $1.49 \pm 0.33$ & $0.76 \pm 0.26$ & $0.52 \pm 0.18$ \\
\hline & $516 \mathrm{~A} 026$ & $14-15$ & -- & -- & -- & -- & $1.4 \pm 0.32$ & $0.7 \pm 0.25$ & $0.57 \pm 0.19$ \\
\hline A06B & 516A027 & $16.5-17.5$ & -- & -- & $0.95 \pm 0.37$ & -- & $1.51 \pm 0.28$ & $0.8 \pm 0.25$ & $0.5 \pm 0.14$ \\
\hline \multirow{2}{*}{ A14 } & 516A019 & $12.5-13.5$ & $1.51 \pm 0.53$ & $\overline{--}$ & -- & $\overline{--}$ & $1.69 \pm 0.38$ & $0.78 \pm 0.26$ & $0.43 \pm 0.19$ \\
\hline & 516A020 & $16-17$ & -- & -- & $0.67 \pm 0.27$ & -- & $1.31 \pm 0.3$ & $0.93 \pm 0.26$ & $0.47 \pm 0.17$ \\
\hline \multirow{3}{*}{ A15 } & 516A021 & $12.5-13.5$ & $1.92 \pm 0.68$ & -- & -- & -- & $1.5 \pm 0.36$ & $0.76 \pm 0.28$ & $0.44 \pm 0.18$ \\
\hline & 516A022 & $16-17$ & $1.32 \pm 0.43$ & -- & $\begin{array}{l}- \\
\end{array}$ & -- & $1.16 \pm 0.26$ & $0.76 \pm 0.22$ & $0.39 \pm 0.15$ \\
\hline & 516A023 & $16-17$ & -- & $\begin{array}{l}- \\
\end{array}$ & $\begin{array}{l}- \\
\end{array}$ & -- & $1.51 \pm 0.39$ & $0.67 \pm 0.27$ & -- \\
\hline \multirow{2}{*}{ A16 } & 516A024 & $12.5-13.5$ & $\overline{--}$ & $\overline{--}$ & $\overline{--}$ & $\overline{--}$ & $1.71 \pm 0.36$ & $0.88 \pm 0.3$ & $0.47 \pm 0.19$ \\
\hline & $516 \mathrm{~A} 025$ & $16-17$ & $1.61 \pm 0.53$ & -- & -- & -- & $1.38 \pm 0.34$ & $0.81 \pm 0.26$ & $0.42 \pm 0.17$ \\
\hline
\end{tabular}

aTaken from the generic guidelines for residual concentrations of Radium-226, Radium-228, Thorium-230, and Thorium-232 as found in Chapter IV of DOE Order 5400.5, Change 2, "Radiation Protection of the Public and Environment." The PAL for these isotopes is specified as $5 \mathrm{pCi} / \mathrm{g}$ averaged over the first 15 centimeters of soil and $15 \mathrm{pCi} / \mathrm{g}$ for deeper soils. For purposes of this document, 15 centimeters is assumed to be equivalent to $0.5 \mathrm{ft}$ ( 6 inches) (DOE, 1993).

${ }^{\mathrm{b}}$ Taken from the Construction, Commercial, Industrial land use scenario in Table 2.1 of the NCRP Report No. 129, Recommended Screening Limits for Contaminated Surface Soil and Review Factors Relevant to Site-Specific Studies (NCRP, 1999). The values provided in this source document were scaled to a 15-mrem per year dose.

$\mathrm{ft}$ bgs $=$ Feet below ground surface

$\mathrm{pCi} / \mathrm{g}=$ Picocuries per gram

$--=$ Not detected at concentrations equal to or greater than minimum detectable concentrations 
Table A.3-7

\section{Septic Tank Results Equal to or Greater than}

Minimum Reporting Limits at CAS 03-59-01

\begin{tabular}{|c|c|c|c|c|}
\hline $\begin{array}{l}\text { Sample } \\
\text { Number }\end{array}$ & $\begin{array}{c}\text { Sample } \\
\text { Matrix }\end{array}$ & Parameter & Result ${ }^{a}$ & Units \\
\hline $\begin{array}{c}516 \text { A501 } \\
\text { (Effluent Chamber) }\end{array}$ & Liquid & 1, 4-Dichlorobenzene & 14 & $\mu \mathrm{g} / \mathrm{L}$ \\
\hline \multirow{2}{*}{$\begin{array}{c}\text { 516A501L } \\
\text { (Effluent Chamber) }\end{array}$} & \multirow{2}{*}{ Liquid } & Chromium & 0.014 & $\mathrm{mg} / \mathrm{L}$ \\
\hline & & Barium & 0.45 & $\mathrm{mg} / \mathrm{L}$ \\
\hline \multirow{8}{*}{$\begin{array}{c}\text { 516A501S } \\
\text { (Effluent Chamber) }\end{array}$} & \multirow{8}{*}{ Solid } & Lead & $58(\mathrm{~J})^{\mathrm{b}}$ & $\mathrm{mg} / \mathrm{kg}$ \\
\hline & & Silver & $6.1(\mathrm{~J})^{\mathrm{c}}$ & $\mathrm{mg} / \mathrm{kg}$ \\
\hline & & Arsenic & 18 & $\mathrm{mg} / \mathrm{kg}$ \\
\hline & & Barium & $190(\mathrm{~J})^{\mathrm{d}}$ & $\mathrm{mg} / \mathrm{kg}$ \\
\hline & & Cadmium & $4.2(\mathrm{~J})^{\mathrm{b}}$ & $\mathrm{mg} / \mathrm{kg}$ \\
\hline & & Chromium & 14 & $\mathrm{mg} / \mathrm{kg}$ \\
\hline & & Selenium & 3.9 & $\mathrm{mg} / \mathrm{kg}$ \\
\hline & & Mercury & $2.1(\mathrm{~J})^{\mathrm{C}}$ & $\mathrm{mg} / \mathrm{kg}$ \\
\hline $\begin{array}{c}\text { 516A501S } \\
\text { (Effluent Chamber) }\end{array}$ & Solid & Diesel-Range Organics & $7,800(L, H, Z)^{e}$ & $\mathrm{mg} / \mathrm{kg}$ \\
\hline \multirow{3}{*}{$\begin{array}{c}\text { 516A502 } \\
\text { (Influent Chamber) }\end{array}$} & \multirow{3}{*}{ Liquid } & Gasoline-Range Organics & $2.5(\mathrm{~J})^{f}$ & $\mathrm{mg} / \mathrm{L}$ \\
\hline & & 1,4-Dichlorobenzene & $2,500(\mathrm{~J})^{9}$ & $\mu \mathrm{g} / \mathrm{L}$ \\
\hline & & Chlorobenzene & $6.5(\mathrm{~J})^{\mathrm{g}}$ & $\mu \mathrm{g} / \mathrm{L}$ \\
\hline \multirow{3}{*}{$\begin{array}{c}\text { 516A502L } \\
\text { (Influent Chamber) }\end{array}$} & \multirow{3}{*}{ Liquid } & Barium & 1.4 & $\mathrm{mg} / \mathrm{L}$ \\
\hline & & Diesel-Range Organics & $0.55(L, Z)$ & $\mathrm{mg} / \mathrm{L}$ \\
\hline & & 1,4-Dichlorobenzene & 590 & $\mu g / L$ \\
\hline \multirow{8}{*}{$\begin{array}{c}\text { 516A502S } \\
\text { (Influent Chamber) }\end{array}$} & \multirow{8}{*}{ Solid } & Lead & $29(\mathrm{~J})^{\mathrm{b}}$ & $\mathrm{mg} / \mathrm{kg}$ \\
\hline & & Arsenic & 6.8 & $\mathrm{mg} / \mathrm{kg}$ \\
\hline & & Barium & $120(\mathrm{~J})^{\mathrm{d}}$ & $\mathrm{mg} / \mathrm{kg}$ \\
\hline & & Cadmium & $2(J)^{b}$ & $\mathrm{mg} / \mathrm{kg}$ \\
\hline & & Chromium & 10 & $\mathrm{mg} / \mathrm{kg}$ \\
\hline & & Selenium & 3.7 & $\mathrm{mg} / \mathrm{kg}$ \\
\hline & & Mercury & $1(\mathrm{~J})^{\mathrm{C}}$ & $\mathrm{mg} / \mathrm{kg}$ \\
\hline & & 1,4-Dichlorobenzene & $2,500,000$ & $\mu \mathrm{g} / \mathrm{kg}$ \\
\hline $\begin{array}{c}\text { 516A502S } \\
\text { (Influent Chamber) }\end{array}$ & Solid & Diesel-Range Organics & $3,600(L, H, Z)^{e}$ & $\mathrm{mg} / \mathbf{k g}$ \\
\hline
\end{tabular}

${ }^{\text {a }}$ Sample results exceeding regulatory limits for disposal are in bold text.

${ }^{b}$ Matrix spike recovery outside control limits. Duplicate precision analysis (relative percent difference) outside control limits.

'Duplicate precision analysis (relative percent difference) outside control limits.

${ }^{\mathrm{d}}$ Matrix spike recovery outside control limits.

eValue exceeded linear calibration range of instrument. The report value is from the dilution run.

${ }^{f}$ Volatile/reactive sample vial contained headspace.

IImproper preservation/pH or not document.

$\mathrm{mg} / \mathrm{kg}=$ Milligrams per kilogram

$\mathrm{mg} / \mathrm{L}=$ Milligrams per liter

$\mu \mathrm{g} / \mathrm{kg}=$ Micrograms per kilogram

$\mu \mathrm{g} / \mathrm{L}=$ Micrograms per liter

NA $=$ Not applicable

$\mathrm{J}=$ Estimated value

$\mathrm{H}=$ The fuel pattern was in the heavier end of the retention time window for the analyte of interest.

$L=$ Fuel pattern in the lighter end of the retention time window.

$Z=A$ significant fraction of the reported result did not resemble the patterns of the following petroleum hydrocarbon products:

Gasoline, JP-4, JP-8, diesel, mineral spirits, motor oil, Stoddard solvent, and Bunker C. 


\section{A.4.0 CAS 03-59-02, Bldg 3C-45 Septic System}

Corrective Action Site 03-59-02 was part of the Area 3 Camp. Building 3C-45 was in operation from 1974 until 1990 or 1991 . The building used for electrical component fabrication, storage, and as a support facility for the nearby Diode Facility.

This CAS is comprised of $215 \mathrm{ft}$ of collection system piping that received effluent from the drains at the former Building 3C-45, a septic tank located east of the building foundation, a distribution box and pipe, a leachfield, and two dry wells. The distribution box is located about $100 \mathrm{ft}$ to the northeast of the septic tank. About $115 \mathrm{ft}$ of piping connects the septic tank to the building, the piping runs from the southeast end of Building 3C-45, east to a clean-out junction, and then northeast to the septic tank. The leachfield has four runs of piping, each approximately $82 \mathrm{ft}$ long. The septic system piping is 4-in. inside diameter plastic and the leachfield piping is 4-in. inside diameter perforated plastic. The septic tank is concrete with the outside dimensions of 8 by 4 by $4.5 \mathrm{ft}$ and is estimated to have a capacity of approximately 1,200 gal. The cylindrical distribution box is also made of concrete and is $3 \mathrm{ft}$ in diameter and $7 \mathrm{ft}$.

As mentioned earlier, this CAS contains two dry wells, one of the dry wells supported the former Mobile Photoprocessing Trailers. This dry well is located $8 \mathrm{ft}$ northeast of the leachfield and was reported to be $4 \mathrm{ft}$ in diameter and approximately $12 \mathrm{ft}$ deep. The other dry well was used by LANL and is located $10 \mathrm{ft}$ west of Building 3C-45, is $6 \mathrm{ft}$ in diameter to a depth of $15.5 \mathrm{ft}$ bgs and $4 \mathrm{ft}$ in diameter to a depth of $44 \mathrm{ft}$ bgs. A floor drain in the building foundation is connected to this dry well with a 2-in. diameter, acid-resistant polypropylene sewer pipe. The type of effluent received by the dry well is unknown. Additional detail is provided in the CAIP (NNSA/NSO, 2003).

\section{A.4.1 Corrective Action Investigation}

A total of 71 environmental soil samples (including 4 duplicates) from 33 sample locations were collected and analyzed during investigation activities conducted at CAS 03-59-02. Sixteen water samples were submitted for QC purposes. One sample was collected for geotechnical purposes and archived. It will be submitted for analysis, if geotechnical information is required during corrective action. Two waste characterization liquid samples were collected from the septic tank and analyzed. 
When collected, the samples appeared to be a liquid; however, when the samples arrived to the laboratory, the samples had separated into three phases (liquid, sludge, and sediment), increasing the total number of samples to eight. The collection of four additional samples on January 16, 2004, increased the total number of samples to 12 . These samples were analyzed for the parameters listed in Table A.4-1. The sample locations are shown in Figure A.4-1.

\section{A.4.1.1 Deviations}

There were no deviations from the investigation activities specified in the CAIP for CAS 03-59-02.

\section{A.4.2 Investigation Activities}

The following sections provide descriptions of the CAS-specific activities conducted to complete Phase I and Phase II investigations as outlined in the CAIP. The specific CAI activities conducted to satisfy the CAIP requirements at CAS 03-59-02 are described in Table A.2-1.

\section{A.4.2.1 Field Screening}

Soil samples were screened for VOCs, TPH, and alpha and beta/gamma radiation. The FSRs were compared to FSLs to guide subsequent sampling and analytical decisions. The VOC FSL was established at $20 \mathrm{ppm}$. The TPH FSL was established at $75 \mathrm{ppm}$.

The radiological FSL for alpha radiation was established daily and ranged between 41.2 and $98.3 \mathrm{dpm} / 100 \mathrm{~cm}^{2}$. The beta/gamma FSL was established daily and ranged between 2,970 and $1,632 \mathrm{dpm} / 100 \mathrm{~cm}^{2}$. Radiological FSLs were not exceeded for soil samples at this CAS.

\section{A.4.2.2 Visual Assessment}

A video inspection of the interior of the septic system piping revealed that the pipe was clean with only minor moisture and a few rocks being observed. All of the interior of the collection system piping with the exception of about $5 \mathrm{ft}$ near the building foundation, was visually inspected. This section of pipe could not be visually inspected because rocks prevented the advancement of the camera. No breaks in the pipe or obvious releases of contaminants were observed during the video 
Table A.4-1

Samples Collected at CAS 03-59-02

(Page 1 of 5 )

\begin{tabular}{|c|c|c|c|c|c|c|c|c|c|c|c|c|c|c|c|c|c|}
\hline $\begin{array}{c}\text { Sample } \\
\text { Location }\end{array}$ & $\begin{array}{l}\text { Sample } \\
\text { Number }\end{array}$ & $\begin{array}{l}\text { Depth } \\
\text { (ft bgs) }\end{array}$ & $\begin{array}{c}\text { Sample } \\
\text { Matrix }\end{array}$ & Purpose & 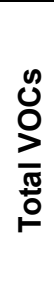 & $\begin{array}{l}\text { o } \\
\text { o } \\
\frac{\pi}{\pi} \\
\frac{0}{0}\end{array}$ & 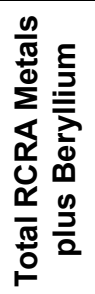 & 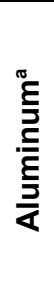 & 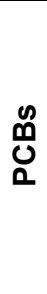 & $\begin{array}{l}\text { O } \\
\text { 足 } \\
\frac{1}{1} \\
\frac{1}{2}\end{array}$ & 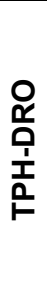 & 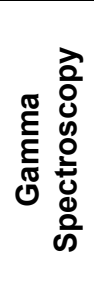 & 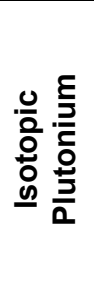 & 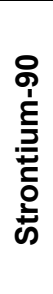 & 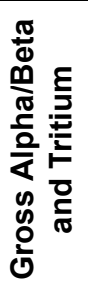 & 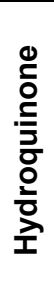 & 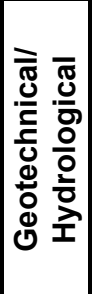 \\
\hline \multirow{2}{*}{ B01 } & 516B001 & $4-5$ & Soll & Environmental & $\bar{X}$ & $\bar{X}$ & $\bar{X}$ & $\bar{X}$ & $\bar{x}$ & $\bar{X}$ & $\bar{x}$ & $\mathrm{X}$ & $\bar{X}$ & $\bar{X}$ & $\overline{---}$ & $\overline{---}$ & $\overline{---}$ \\
\hline & 516B002 & $9-10$ & Soil & Environmental & $\mathrm{X}$ & $\mathrm{X}$ & $\mathrm{X}$ & $\mathrm{X}$ & $\bar{X}$ & $\bar{X}$ & $\bar{X}$ & -- & $\mathrm{X}$ & $\mathrm{X}$ & -- & -- & -- \\
\hline \multirow{2}{*}{ B02 } & 516B003 & $4-5$ & Soil & Environmental & $\mathrm{X}$ & $\mathrm{X}$ & $\mathrm{X}$ & $\mathrm{X}$ & $\bar{X}$ & $\mathrm{X}$ & $\bar{X}$ & $\mathrm{X}$ & $\mathrm{X}$ & $\mathrm{X}$ & -- & -- & -- \\
\hline & 516B004 & $9-10$ & Soil & Environmental & $\bar{X}$ & $\mathrm{X}$ & $\mathrm{X}$ & $\mathrm{X}$ & $\bar{X}$ & $\bar{X}$ & $\bar{X}$ & -- & $\mathrm{X}$ & $\mathrm{X}$ & -- & -- & -- \\
\hline \multirow{2}{*}{ B03 } & 516B005 & $4-5$ & Soil & Environmental & $x$ & $\mathrm{X}$ & $\mathrm{X}$ & $\mathrm{X}$ & $x$ & $x$ & $x$ & -- & $\mathrm{X}$ & $\mathrm{X}$ & -- & -- & -- \\
\hline & $516 \mathrm{~B} 006$ & $7-8$ & Soil & Environmental & $\mathrm{X}$ & $\mathrm{X}$ & $\mathrm{X}$ & $\mathrm{X}$ & $x$ & $x$ & $X$ & $\mathrm{X}$ & $\mathrm{X}$ & $\mathrm{X}$ & -- & -- & -- \\
\hline \multirow{4}{*}{ B04 } & 516B007 & $4-5$ & Soil & Environmental & $\mathrm{X}$ & $\mathrm{X}$ & $\mathrm{X}$ & $\mathrm{X}$ & $\mathrm{X}$ & $x$ & $\mathrm{X}$ & -- & $\mathrm{X}$ & $\mathrm{X}$ & -- & -- & -- \\
\hline & 516B008 & $7-8$ & Soil & Environmental & $\mathrm{X}$ & $\mathrm{X}$ & $\mathrm{X}$ & $\mathrm{X}$ & $\mathrm{X}$ & $\mathrm{X}$ & $\mathrm{X}$ & -- & $\mathrm{X}$ & $\mathrm{X}$ & -- & -- & -- \\
\hline & 516B065 & $10.5-11.5$ & Soil & Environmental & -- & -- & -- & -- & -- & -- & -- & -- & $\mathrm{X}$ & -- & -- & -- & -- \\
\hline & 516B066 & $14-15$ & Soil & Environmental & -- & -- & -- & -- & -- & -- & -- & -- & $\mathrm{X}$ & -- & -- & -- & -- \\
\hline \multirow{2}{*}{ B05 } & $516 \mathrm{~B} 009$ & $6-7$ & Soil & Environmental & $\mathrm{X}$ & $\mathrm{X}$ & $\mathrm{X}$ & $\bar{x}$ & $\bar{X}$ & $\bar{X}$ & $\bar{X}$ & $\mathrm{X}$ & $\mathrm{X}$ & $\mathrm{X}$ & -- & -- & -- \\
\hline & 516B010 & $9.5-10.5$ & Soil & Environmental & $\mathrm{X}$ & $\mathrm{X}$ & $\mathrm{X}$ & $\mathrm{X}$ & $\bar{X}$ & $\bar{X}$ & $\bar{X}$ & -- & $\mathrm{X}$ & $\mathrm{X}$ & -- & -- & -- \\
\hline \multirow{6}{*}{ B06 } & 516B011 & $5.5-6.5$ & Soil & Environmental & $\mathrm{X}$ & $\mathrm{X}$ & $\mathrm{X}$ & -- & $\bar{X}$ & $\mathrm{X}$ & $\mathrm{X}$ & -- & $\mathrm{X}$ & $\mathrm{X}$ & -- & -- & -- \\
\hline & 516B012 & $5.5-6.5$ & Soil & $\begin{array}{c}\text { Duplicate of } \\
516 \mathrm{~B} 011\end{array}$ & $x$ & $x$ & $x$ & -- & $x$ & $X$ & $\mathrm{X}$ & -- & $X$ & $x$ & -- & -- & -- \\
\hline & 516B013 & $8.5-9.5$ & Soil & Environmental & $\mathrm{X}$ & $\mathrm{X}$ & $\mathrm{X}$ & $\overline{--}$ & $\bar{X}$ & $\bar{X}$ & $\bar{X}$ & $\mathrm{X}$ & $\mathrm{X}$ & $\mathrm{X}$ & -- & -- & -- \\
\hline & 516B069 & $10.5-11.5$ & Soil & Environmental & -- & -- & -- & $\mathrm{X}$ & -- & -- & -- & -- & $\mathrm{X}$ & -- & -- & -- & -- \\
\hline & 516B070 & $10.5-11.5$ & Soil & $\begin{array}{c}\text { Duplicate of } \\
\text { 516B069 }\end{array}$ & -- & -- & -- & $x$ & -- & -- & -- & -- & $X$ & -- & -- & -- & -- \\
\hline & 516B071 & $14-15$ & Soil & Environmental & -- & $\overline{--}$ & -- & $\mathrm{X}$ & -- & -- & -- & $\overline{--}$ & $\mathrm{X}$ & $\overline{--}$ & -- & $\overline{--}$ & $\overline{--}$ \\
\hline \multirow{3}{*}{ B07 } & 516B014 & $5.5-6.5$ & Soil & Environmental & $\mathrm{X}$ & $\bar{X}$ & $\bar{X}$ & -- & $\bar{X}$ & $\bar{X}$ & $\bar{X}$ & -- & $\bar{X}$ & $\mathrm{X}$ & -- & -- & -- \\
\hline & 516B067 & $10.5-11.5$ & Soil & Environmental & -- & -- & -- & $\mathrm{X}$ & -- & -- & -- & -- & $\mathrm{X}$ & -- & -- & -- & -- \\
\hline & 516B068 & $14-15$ & Soil & Environmental & -- & -- & -- & $\mathrm{X}$ & -- & -- & -- & -- & $\mathrm{X}$ & -- & -- & -- & -- \\
\hline \multirow{2}{*}{ B08 } & 516B015 & $7-8$ & Soil & Environmental & $\mathrm{X}$ & $\mathrm{X}$ & $\mathrm{X}$ & $\mathrm{X}$ & $\mathrm{X}$ & $\mathrm{X}$ & $x$ & -- & $\mathrm{X}$ & $\mathrm{X}$ & -- & -- & -- \\
\hline & 516B016 & $10.5-11.5$ & Soil & Environmental & $\mathrm{X}$ & $\mathrm{X}$ & $\mathrm{X}$ & -- & $\mathrm{X}$ & $\mathrm{X}$ & $\mathrm{X}$ & -- & $\mathrm{X}$ & $\mathrm{X}$ & -- & -- & -- \\
\hline B09 & 516B017 & $7-8$ & Soil & Environmental & $\mathrm{X}$ & $\mathrm{X}$ & $\mathrm{X}$ & -- & $x$ & $\mathrm{X}$ & $\mathrm{X}$ & -- & $\mathrm{X}$ & $\mathrm{X}$ & -- & -- & -- \\
\hline B10 & 516B018 & $7-8$ & Soil & Environmental & $\mathrm{X}$ & $\mathrm{X}$ & $\mathrm{X}$ & -- & $\mathrm{X}$ & $\mathrm{X}$ & $x$ & -- & $\mathrm{X}$ & $\mathrm{X}$ & -- & -- & -- \\
\hline
\end{tabular}


Table A.4-1

Samples Collected at CAS 03-59-02

(Page 2 of 5 )

\begin{tabular}{|c|c|c|c|c|c|c|c|c|c|c|c|c|c|c|c|c|c|}
\hline $\begin{array}{l}\text { Sample } \\
\text { Location }\end{array}$ & $\begin{array}{l}\text { Sample } \\
\text { Number }\end{array}$ & $\begin{array}{l}\text { Depth } \\
\text { (ft bgs) }\end{array}$ & $\begin{array}{c}\text { Sample } \\
\text { Matrix }\end{array}$ & Purpose & 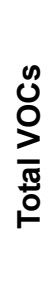 & 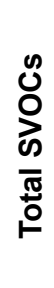 & 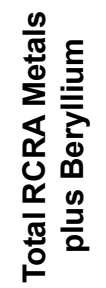 & 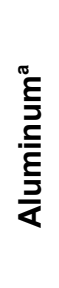 & 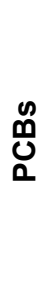 & 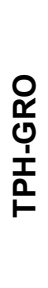 & 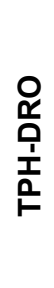 & 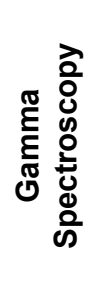 & 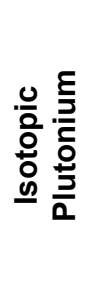 & 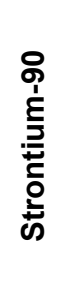 & 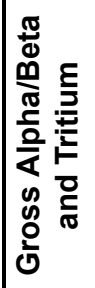 & 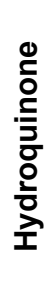 & 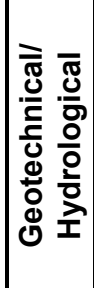 \\
\hline \multirow{2}{*}{ B11 } & 516B019 & $7-8$ & Soll & Environmental & $\mathrm{X}$ & $\mathrm{X}$ & $x$ & -- & $\bar{x}$ & $\mathrm{X}$ & $\mathrm{X}$ & $X$ & $\mathrm{X}$ & $\mathrm{X}$ & -- & -- & -- \\
\hline & 516B020 & $10.5-11.5$ & Soil & Environmental & $\bar{X}$ & $\bar{X}$ & $\mathrm{X}$ & -- & $\mathrm{X}$ & $\mathrm{X}$ & $\mathrm{X}$ & $\mathrm{X}$ & $\mathrm{X}$ & $\mathrm{X}$ & -- & -- & $\overline{--}$ \\
\hline B12 & 516B021 & $7-8$ & Soil & Environmental & $\mathrm{X}$ & $\mathrm{X}$ & $\mathrm{X}$ & -- & $\mathrm{X}$ & $\mathrm{X}$ & $\mathrm{X}$ & -- & $\mathrm{X}$ & $\mathrm{X}$ & -- & -- & -- \\
\hline B13 & 516B022 & $7-8$ & Soil & Environmental & $\mathrm{X}$ & $\mathrm{X}$ & $\mathrm{X}$ & -- & $\mathrm{X}$ & $\mathrm{X}$ & $\mathrm{X}$ & -- & $\mathrm{X}$ & $\mathrm{X}$ & $\overline{--}$ & -- & $\overline{--}$ \\
\hline B14 & 516B023 & $7-8$ & Soil & Environmental & $\mathrm{X}$ & $\mathrm{X}$ & $\mathrm{X}$ & -- & $\mathrm{X}$ & $\mathrm{X}$ & $\mathrm{X}$ & $\mathrm{X}$ & $\mathrm{X}$ & $\mathrm{X}$ & -- & -- & -- \\
\hline B15 & 516B024 & $7-8$ & Soil & Environmental & $\mathrm{X}$ & $\mathrm{X}$ & $\mathrm{X}$ & -- & $\mathrm{X}$ & $\mathrm{X}$ & $\mathrm{X}$ & -- & $\mathrm{X}$ & $\mathrm{X}$ & -- & -- & -- \\
\hline \multirow{2}{*}{ B16 } & $516 \mathrm{~B} 025^{\mathrm{b}}$ & $12-13$ & Soil & Environmental & $x$ & $X$ & $\begin{array}{l}\text { Plus } \\
\text { TCLP } \\
\text { Silver }\end{array}$ & $X$ & $X$ & $X$ & $X$ & -- & -- & -- & -- & $X$ & -- \\
\hline & $516 \mathrm{~B} 026^{\mathrm{b}}$ & $16-17$ & Soil & Environmental & $x$ & $X$ & $\begin{array}{l}\text { Plus } \\
\text { TCLP } \\
\text { Silver }\end{array}$ & $X$ & $X$ & $X$ & $X$ & $X$ & -- & -- & -- & $X$ & -- \\
\hline \multirow{2}{*}{ B17 } & 516B027 & $12-13$ & Soil & Environmental & $\mathrm{X}$ & $\mathrm{X}$ & $\mathrm{X}$ & $\mathrm{X}$ & $\mathrm{X}$ & $\mathrm{X}$ & $\mathrm{X}$ & -- & -- & -- & -- & $\mathrm{X}$ & -- \\
\hline & 516B028 & $16-17$ & Soil & Environmental & $\bar{x}$ & $\bar{X}$ & $\mathrm{X}$ & $\mathrm{X}$ & $\mathrm{X}$ & $\mathrm{X}$ & $\mathrm{X}$ & -- & -- & -- & -- & $\mathrm{X}$ & -- \\
\hline \multirow{2}{*}{ B18 } & 516B029 & $12-13$ & Soil & Environmental & $\bar{X}$ & $\bar{X}$ & $\bar{X}$ & $\bar{X}$ & $\bar{X}$ & $\mathrm{X}$ & $\bar{X}$ & $\overline{--}$ & -- & -- & $\overline{--}$ & $\bar{X}$ & -- \\
\hline & $516 \mathrm{~B} 030$ & $16-17$ & Soil & Environmental & $\bar{x}$ & $\mathrm{X}$ & $\mathrm{X}$ & $\mathrm{X}$ & $\mathrm{X}$ & $\mathrm{X}$ & $\mathrm{X}$ & $\mathrm{X}$ & -- & -- & -- & $\mathrm{X}$ & -- \\
\hline \multirow{4}{*}{ B19 } & 516B031 & $12-13$ & Soil & Environmental & $x$ & $x$ & $\mathrm{X}$ & -- & $\mathrm{X}$ & $\mathrm{X}$ & $\mathrm{X}$ & -- & -- & -- & -- & $\mathrm{X}$ & -- \\
\hline & 516B032 & $12-13$ & Soil & $\begin{array}{c}\text { Duplicate of } \\
516 \mathrm{~B} 031\end{array}$ & $x$ & $X$ & $X$ & -- & $X$ & $X$ & $X$ & -- & -- & -- & -- & $X$ & -- \\
\hline & 516B033 & $16-17$ & Soil & Environmental & $\mathrm{X}$ & $x$ & $\mathrm{X}$ & -- & $\mathrm{X}$ & $\mathrm{X}$ & $\mathrm{X}$ & $\mathrm{X}$ & -- & -- & -- & $\mathrm{X}$ & -- \\
\hline & 516BGT01 & $10-11$ & Soil & Geotechnical & -- & -- & -- & -- & -- & -- & -- & -- & -- & -- & -- & -- & $\mathrm{X}$ \\
\hline \multirow{3}{*}{ B20 } & 516B034 & $6-7$ & Soil & Environmental & $\mathrm{X}$ & $\mathrm{X}$ & $\mathrm{X}$ & -- & $\mathrm{X}$ & $\mathrm{X}$ & $\mathrm{X}$ & $\mathrm{X}$ & $\mathrm{X}$ & $\mathrm{X}$ & -- & -- & -- \\
\hline & 516B035 & $10-11$ & Soil & Environmental & $\bar{X}$ & $\mathrm{X}$ & $\mathrm{X}$ & -- & $\mathrm{X}$ & $\mathrm{X}$ & $\mathrm{X}$ & $\mathrm{X}$ & $\mathrm{X}$ & $\mathrm{X}$ & -- & -- & -- \\
\hline & 516B036 & $17-18$ & Soil & Environmental & $\bar{X}$ & $\mathrm{X}$ & $\mathrm{X}$ & -- & $\mathrm{X}$ & $\mathrm{X}$ & $\mathrm{X}$ & $\mathrm{X}$ & $\mathrm{X}$ & $\mathrm{X}$ & -- & -- & -- \\
\hline \multirow{3}{*}{ B21 } & 516B037 & $26-27$ & Soil & Environmental & $\bar{X}$ & $\mathrm{X}$ & $\mathrm{X}$ & -- & $\mathrm{X}$ & $\mathrm{X}$ & $\mathrm{X}$ & $\mathrm{X}$ & $\mathrm{X}$ & $\mathrm{X}$ & -- & -- & -- \\
\hline & 516B038 & $42-43$ & Soil & Environmental & $\mathrm{X}$ & $\mathrm{X}$ & $\mathrm{X}$ & -- & $\mathrm{X}$ & $\mathrm{X}$ & $\mathrm{X}$ & $\mathrm{X}$ & $\mathrm{X}$ & $\mathrm{X}$ & -- & -- & -- \\
\hline & 516B039 & $48-49$ & Soil & Environmental & $\mathrm{X}$ & $\mathrm{X}$ & $\mathrm{X}$ & -- & $\mathrm{X}$ & $\mathrm{X}$ & $\mathrm{X}$ & $\mathrm{X}$ & $\mathrm{X}$ & $\mathrm{X}$ & -- & -- & -- \\
\hline
\end{tabular}


Table A.4-1

Samples Collected at CAS 03-59-02

(Page 3 of 5)

\begin{tabular}{|c|c|c|c|c|c|c|c|c|c|c|c|c|c|c|c|c|c|}
\hline $\begin{array}{c}\text { Sample } \\
\text { Location }\end{array}$ & $\begin{array}{l}\text { Sample } \\
\text { Number }\end{array}$ & $\begin{array}{l}\text { Depth } \\
\text { (ft bgs) }\end{array}$ & $\begin{array}{c}\text { Sample } \\
\text { Matrix }\end{array}$ & Purpose & 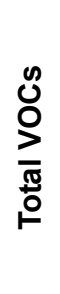 & $\begin{array}{l}0 \\
\text { o } \\
\frac{\pi}{\pi} \\
\frac{\pi}{0}\end{array}$ & 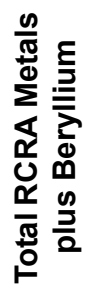 & 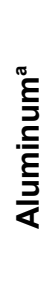 & $\begin{array}{c}\mathscr{n} \\
\text { 品 }\end{array}$ & $\begin{array}{l}\text { O } \\
\text { ơ } \\
\text { İ } \\
\text { İ } \\
\text { R }\end{array}$ & 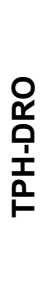 & 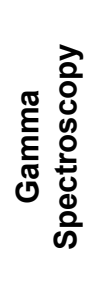 & 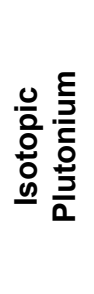 & 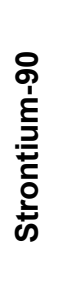 & 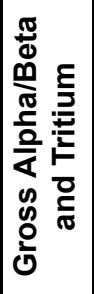 & 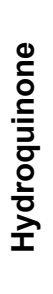 & 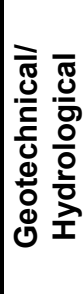 \\
\hline \multirow{2}{*}{ B22 } & 516B040 & $42-43$ & Soll & Environmental & $\mathrm{X}$ & $\mathrm{X}$ & $\mathrm{X}$ & -- & $x$ & $\mathrm{X}$ & $\mathrm{X}$ & $\mathrm{X}$ & $\mathrm{X}$ & $\mathrm{X}$ & -- & -- & $\overline{--}$ \\
\hline & 516B041 & $48-49$ & Soil & Environmental & $\mathrm{X}$ & $\mathrm{X}$ & $\mathrm{X}$ & -- & $\bar{X}$ & $\mathrm{X}$ & $\mathrm{X}$ & $\mathrm{X}$ & $\mathrm{X}$ & $\mathrm{X}$ & -- & -- & -- \\
\hline \multirow{3}{*}{ B23 } & 516B042 & $12.5-13.5$ & Soil & Environmental & -- & -- & -- & -- & -- & -- & -- & -- & $\mathrm{X}$ & -- & -- & -- & -- \\
\hline & 516B043 & $16-17$ & Soil & Environmental & -- & -- & -- & -- & -- & -- & -- & -- & $X$ & -- & -- & -- & -- \\
\hline & 516B044 & $16-17$ & Soil & $\begin{array}{c}\text { Duplicate of } \\
516 \mathrm{~B} 043\end{array}$ & -- & -- & -- & -- & -- & -- & -- & -- & $X$ & -- & -- & -- & -- \\
\hline \multirow{2}{*}{ B24 } & 516B045 & $12.5-13.5$ & Soil & Environmental & -- & -- & -- & -- & -- & -- & -- & -- & $\mathrm{X}$ & -- & -- & -- & -- \\
\hline & 516B046 & $16-17$ & Soil & Environmental & -- & -- & -- & -- & -- & -- & -- & -- & $\mathrm{X}$ & -- & -- & -- & -- \\
\hline \multirow{2}{*}{ B25 } & 516B047 & $12.5-13.5$ & Soil & Environmental & -- & -- & -- & -- & -- & -- & -- & -- & $\mathrm{X}$ & -- & -- & -- & -- \\
\hline & 516B048 & $16-17$ & Soil & Environmental & -- & -- & -- & -- & -- & -- & -- & -- & $\mathrm{X}$ & -- & -- & -- & -- \\
\hline \multirow{2}{*}{ B26 } & 516B049 & $12.5-13.5$ & Soil & Environmental & -- & -- & -- & -- & -- & -- & -- & -- & $\mathrm{X}$ & -- & -- & -- & -- \\
\hline & 516B050 & $16-17$ & Soil & Environmental & -- & -- & -- & -- & -- & -- & -- & -- & $\mathrm{X}$ & -- & -- & -- & -- \\
\hline \multirow{2}{*}{ B27 } & 516B051 & $10.5-11.5$ & Soil & Environmental & -- & -- & -- & -- & -- & -- & -- & -- & $\mathrm{X}$ & -- & -- & -- & -- \\
\hline & 516B052 & $14-15$ & Soil & Environmental & -- & -- & -- & -- & -- & -- & -- & -- & $\bar{X}$ & -- & -- & -- & -- \\
\hline \multirow{2}{*}{ B28 } & 516B053 & $10.5-11.5$ & Soil & Environmental & -- & -- & -- & -- & -- & -- & -- & -- & $\mathrm{X}$ & -- & -- & -- & -- \\
\hline & 516B054 & $14-15$ & Soil & Environmental & -- & -- & -- & -- & -- & -- & -- & -- & $\mathrm{X}$ & -- & -- & -- & -- \\
\hline \multirow{2}{*}{ B29 } & 516B055 & $10.5-11.5$ & Soil & Environmental & -- & -- & -- & -- & -- & -- & -- & -- & $\mathrm{X}$ & -- & -- & -- & -- \\
\hline & 516B056 & $14-15$ & Soil & Environmental & -- & -- & -- & -- & -- & -- & -- & -- & $\mathrm{X}$ & -- & -- & -- & -- \\
\hline \multirow{2}{*}{ B30 } & 516B057 & $10.5-11.5$ & Soil & Environmental & -- & -- & -- & -- & -- & -- & -- & -- & $\mathrm{X}$ & -- & -- & -- & -- \\
\hline & 516B058 & $14-15$ & Soil & Environmental & -- & -- & -- & -- & -- & -- & -- & -- & $\mathrm{X}$ & -- & -- & -- & -- \\
\hline \multirow{2}{*}{ B31 } & 516B059 & $10.5-11.5$ & Soil & Environmental & -- & -- & -- & -- & -- & -- & -- & -- & $\mathrm{X}$ & -- & -- & -- & -- \\
\hline & 516B060 & $14-15$ & Soil & Environmental & -- & -- & -- & -- & -- & -- & -- & -- & $\mathrm{X}$ & -- & -- & -- & -- \\
\hline \multirow{2}{*}{ B32 } & 516B061 & $10.5-11.5$ & Soil & Environmental & -- & -- & -- & -- & -- & -- & -- & -- & $X$ & -- & -- & -- & -- \\
\hline & 516B062 & $14-15$ & Soil & Environmental & -- & -- & -- & -- & -- & -- & -- & -- & $\mathrm{X}$ & -- & -- & -- & -- \\
\hline \multirow{2}{*}{ B33 } & 516B063 & $10.5-11.5$ & Soil & Environmental & -- & -- & -- & -- & -- & -- & -- & -- & $\mathrm{X}$ & -- & -- & -- & -- \\
\hline & 516B064 & $14-15$ & Soil & Environmental & -- & -- & -- & -- & -- & -- & -- & -- & $\mathrm{X}$ & -- & -- & -- & -- \\
\hline
\end{tabular}


Table A.4-1

Samples Collected at CAS 03-59-02

(Page 4 of 5)

\begin{tabular}{|c|c|c|c|c|c|c|c|c|c|c|c|c|c|c|c|c|c|}
\hline $\begin{array}{l}\text { Sample } \\
\text { Location }\end{array}$ & $\begin{array}{l}\text { Sample } \\
\text { Number }\end{array}$ & $\begin{array}{l}\text { Depth } \\
\text { (ft bgs) }\end{array}$ & $\begin{array}{l}\text { Sample } \\
\text { Matrix }\end{array}$ & Purpose & 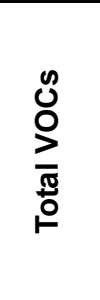 & 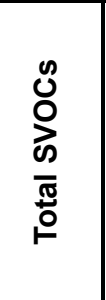 & 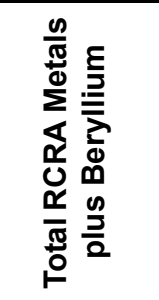 & & $\begin{array}{c}\mathscr{0} \\
\stackrel{0}{\alpha} \\
0\end{array}$ & 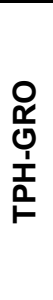 & 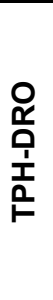 & 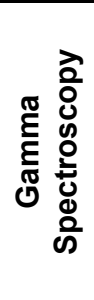 & 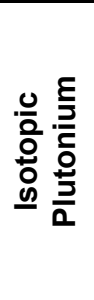 & 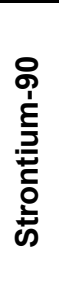 & 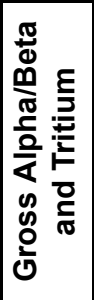 & 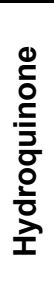 & 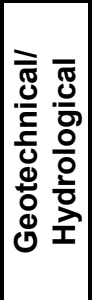 \\
\hline \multirow{6}{*}{$\begin{array}{c}\text { Septic } \\
\text { Tank - } \\
\text { Effluent } \\
\text { Chamber }\end{array}$} & 516B501 & NA & Liquid & $\begin{array}{c}\text { Waste } \\
\text { Characterization }\end{array}$ & $x$ & -- & -- & -- & -- & $x$ & -- & -- & -- & -- & -- & -- & -- \\
\hline & $516 \mathrm{~B} 501 \mathrm{~L}^{\mathrm{d}}$ & NA & Liquid & $\begin{array}{c}\text { Waste } \\
\text { Characterization }\end{array}$ & -- & $X$ & $X^{c}$ & -- & $X^{c}$ & -- & $X$ & -- & -- & -- & -- & -- & -- \\
\hline & $516 \mathrm{~B} 501 \mathrm{~S}^{d}$ & NA & Sediment & $\begin{array}{c}\text { Waste } \\
\text { Characterization }\end{array}$ & -- & $X$ & $x$ & -- & $X^{c}$ & -- & $X$ & -- & -- & -- & -- & -- & -- \\
\hline & $516 \mathrm{~B} 501 \mathrm{SL}^{d}$ & NA & Sludge & $\begin{array}{c}\text { Waste } \\
\text { Characterization }\end{array}$ & -- & -- & -- & -- & -- & -- & -- & $x$ & $x$ & $x$ & $x$ & -- & -- \\
\hline & 516B503 & NA & Liquid & $\begin{array}{c}\text { Waste } \\
\text { Characterization }\end{array}$ & -- & -- & $X($ no Be $)$ & -- & -- & -- & -- & $X$ & -- & -- & $X$ & -- & -- \\
\hline & 516B504 & NA & Solid & $\begin{array}{c}\text { Waste } \\
\text { Characterization }\end{array}$ & TCLP & TCLP & TCLP & -- & $x$ & -- & -- & $x$ & -- & -- & -- & -- & -- \\
\hline \multirow{6}{*}{$\begin{array}{c}\text { Septic } \\
\text { Tank - } \\
\text { Influent } \\
\text { Chamber }\end{array}$} & 516B502 & NA & Liquid & $\begin{array}{c}\text { Waste } \\
\text { Characterization }\end{array}$ & $X$ & -- & -- & -- & -- & $X$ & -- & -- & -- & -- & -- & -- & -- \\
\hline & $516 B 502 L^{d}$ & NA & Liquid & $\begin{array}{c}\text { Waste } \\
\text { Characterization }\end{array}$ & -- & $X$ & $x^{c}$ & -- & $x^{c}$ & -- & $x$ & -- & -- & -- & -- & -- & -- \\
\hline & $516 B 502 S^{d}$ & NA & Sediment & $\begin{array}{c}\text { Waste } \\
\text { Characterization }\end{array}$ & -- & $x$ & $x$ & -- & $X^{c}$ & -- & $X$ & -- & -- & -- & -- & -- & -- \\
\hline & $516 \mathrm{~B} 502 \mathrm{SL}^{\mathrm{d}}$ & NA & Sludge & $\begin{array}{c}\text { Waste } \\
\text { Characterization }\end{array}$ & -- & -- & -- & -- & -- & -- & -- & $X^{c}$ & $x$ & $X$ & $x$ & -- & -- \\
\hline & 516B505 & NA & Liquid & $\begin{array}{c}\text { Waste } \\
\text { Characterization }\end{array}$ & -- & -- & $X($ no Be $)$ & -- & $X$ & -- & -- & $x$ & -- & -- & $X$ & -- & -- \\
\hline & 516B506 & NA & Solid & $\begin{array}{c}\text { Waste } \\
\text { Characterization }\end{array}$ & TCLP & TCLP & TCLP & TCLP & $X$ & -- & -- & $X$ & -- & -- & -- & -- & -- \\
\hline
\end{tabular}


Table A.4-1

Samples Collected at CAS 03-59-02

(Page 5 of 5 )

\begin{tabular}{|c|c|c|c|c|c|c|c|c|c|c|c|c|c|c|c|c|c|}
\hline $\begin{array}{l}\text { Sample } \\
\text { Location }\end{array}$ & $\begin{array}{l}\text { Sample } \\
\text { Number }\end{array}$ & $\begin{array}{c}\text { Depth } \\
\text { (ft bgs) }\end{array}$ & $\begin{array}{c}\text { Sample } \\
\text { Matrix }\end{array}$ & Purpose & $\begin{array}{l}\text { 仓ั } \\
\text { O } \\
\frac{\pi}{5} \\
0\end{array}$ & $\begin{array}{l}0 \\
0 \\
0 \\
\frac{0}{\pi} \\
0 \\
0\end{array}$ & 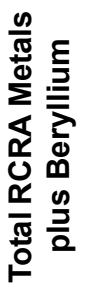 & 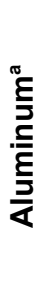 & 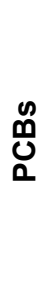 & 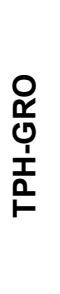 & 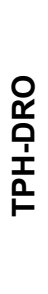 & 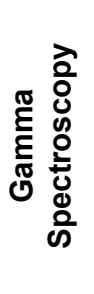 & 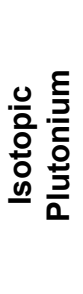 & 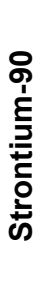 & 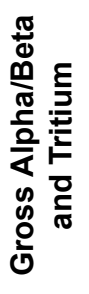 & 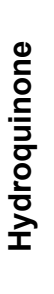 & 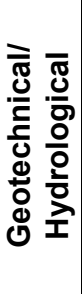 \\
\hline \multirow{16}{*}{ NA } & $516 B 301$ & $\mathrm{NA}$ & Water & Trip Blank & $\mathrm{X}$ & -- & -- & -- & -- & -- & -- & -- & -- & -- & -- & -- & -- \\
\hline & 516B302 & NA & Water & Trip Blank & $\mathrm{X}$ & -- & -- & -- & -- & -- & -- & -- & -- & -- & -- & -- & -- \\
\hline & 516B303 & NA & Water & Trip Blank & $\mathrm{X}$ & -- & -- & -- & -- & -- & -- & -- & -- & -- & -- & -- & -- \\
\hline & 516B304 & NA & Water & Trip Blank & $\mathrm{X}$ & -- & -- & -- & -- & -- & -- & -- & -- & -- & -- & -- & -- \\
\hline & 516B305 & NA & Water & Trip Blank & $\mathrm{X}$ & -- & -- & -- & -- & -- & -- & -- & -- & -- & -- & -- & -- \\
\hline & 516B306 & $\mathrm{NA}$ & Water & Field Blank & $\mathrm{X}$ & $\bar{X}$ & $\mathrm{X}$ & -- & $\bar{X}$ & $\mathrm{X}$ & -- & $\mathrm{X}$ & $\mathrm{X}$ & $\bar{X}$ & -- & $\mathrm{X}$ & -- \\
\hline & 516B307 & NA & Water & Trip Blank & $\mathrm{X}$ & -- & -- & -- & -- & -- & -- & -- & -- & -- & -- & -- & -- \\
\hline & 516B308 & NA & Water & Trip Blank & $\mathrm{X}$ & -- & -- & -- & -- & -- & -- & -- & -- & -- & -- & -- & -- \\
\hline & 516B309 & NA & Water & Rinsate Blank & $\mathrm{X}$ & $\bar{X}$ & $X$ & -- & $\bar{X}$ & $X$ & -- & $x$ & $X$ & $\bar{X}$ & $X$ & $\mathrm{X}$ & -- \\
\hline & 516B310 & NA & Water & Trip Blank & $\mathrm{X}$ & -- & -- & -- & -- & -- & -- & -- & -- & -- & -- & -- & -- \\
\hline & 516B311 & $\overline{\mathrm{NA}}$ & Water & Trip Blank & $\mathrm{X}$ & -- & -- & -- & -- & -- & -- & -- & -- & -- & -- & -- & -- \\
\hline & 516B312 & NA & Water & Source Blank & $\mathrm{X}$ & $\mathrm{X}$ & $\mathrm{X}$ & -- & $\bar{x}$ & $\mathrm{X}$ & -- & $\mathrm{X}$ & $\mathrm{X}$ & $\bar{x}$ & -- & $\mathrm{x}$ & -- \\
\hline & 516B313 & NA & Water & Trip Blank & $\mathrm{X}$ & -- & -- & -- & -- & -- & -- & -- & -- & -- & -- & -- & -- \\
\hline & 516B314 & $\mathrm{NA}$ & Water & Trip Blank & $\mathrm{X}$ & -- & -- & -- & -- & -- & -- & -- & -- & -- & -- & -- & -- \\
\hline & 516B315 & NA & Water & Field Blank & -- & -- & -- & -- & -- & -- & -- & -- & $\mathrm{x}$ & -- & -- & -- & -- \\
\hline & 516B316 & NA & Water & Rinsate Blank & -- & -- & -- & -- & -- & -- & -- & -- & $\mathrm{X}$ & -- & -- & -- & -- \\
\hline
\end{tabular}

aAluminum to be run on photoprocessing dry well samples only.

${ }^{\mathrm{b}} \mathrm{TCLP}$ silver was analyzed for in samples 516B025 and 516B026. TCLP silver was only detected in Sample $516 \mathrm{~B} 025$ at a concentration of $0.13 \mathrm{mg} / \mathrm{L}$. The result is below the regulatory limit.

Analytical results were superseded by results of samples (516B503, 516B504, 516B505, and 516B506) collected on January 16, 2004.

dSample split into liquid, sediment, and sludge samples by the laboratory and analyzed separately

$\mathrm{L}=$ Liquid

NA- = Not applicable

$S=$ Sediment

$\mathrm{SL}=$ Sludge

-- = Not analyzed 


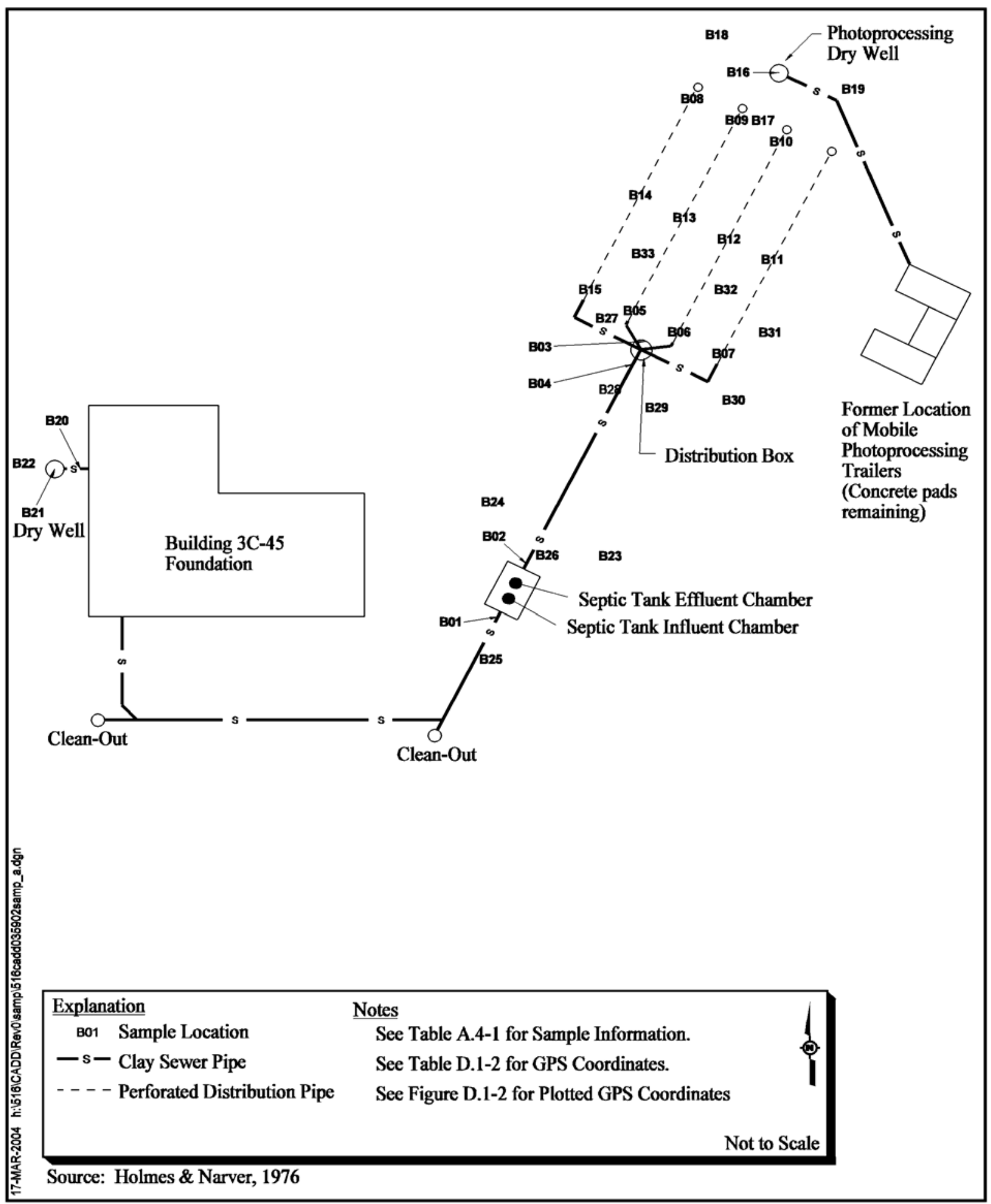

Figure A.4-1

CAU 516, CAS 03-59-02, BIdg 3C-45 Septic System, Sample Locations 
inspection although there was some pipe corrosion near the building. No material was present in sufficient quantity to sample in the collection system piping.

Samples were collected beneath the influent and effluent pipes of the septic tank and distribution box, from the soil horizon beneath the septic tank and distribution box, from the interface of the leachrock and native soil within the leachfield, from the two dry wells, and below the pipe leading to the dry wells. No breaks in the pipes or obvious release of contaminants were observed during the excavations around these components.

\section{A.4.2.3 Intrusive Investigation Activities}

This section discusses the intrusive sampling that was conducted at CAS 03-59-02.

\section{A.4.2.3.1 Initial Sampling}

In accordance with the CAIP, initial sampling activities included the collection of subsurface soil samples below the piping connected to the septic tank and distribution box (locations B01, B02, B03, and B04), below the septic tank and distribution box (B01 and B03), at the interface of the leachfield material and native soil below the leachfield piping (B05 through B15), from the two dry wells (B16 and B21), and beneath the piping leading to the dry wells (B19 and B20).

Twenty soil samples were collected at locations B01 through B15, including samples collected at the interface of the leachfield material and the native soil. All these samples were collected with the aid of a backhoe. Two samples were collected from the septic tank (one each from the influent and effluent chambers). These samples were submitted for waste characterization purposes.

Nine samples were collected at the photoprocessing dry well locations B16, B17, B18, and B19 from 12 to $17 \mathrm{ft}$ bgs. There was no residual material identified as contaminated encountered while drilling through the dry well. Location B16 is at the interface of the leachrock and native soil. Locations B17, B18, and B19 were adjacent to the dry well.

Eight samples were collected at the LANL dry well at locations B20, B21, and B22 from 6 to $49 \mathrm{ft}$ bgs. There was no residual material identified as potentially contaminated encountered while drilling through the dry well. Samples were collected at the interface of the fill material and the 
native soil. Samples were also taken below the interface in the dry well and at boreholes adjacent to the dry well.

One geotechnical sample was collected in the native soil at location B19 from 10 to $11 \mathrm{ft}$ bgs southeast of the photoprocessing dry well. The sample was not analyzed. It has been archived and will be analyzed if geotechnical information is required during the corrective actions.

\section{A.4.2.4 Step-out Sampling}

Thirty samples were collected during step-out sampling. Four locations (B02, B04, B06, and B07) were identified from the Phase I sampling activities as locations of concern due to the presence of $\mathrm{Pu}-239$ at concentrations greater than the PALs. To define the extent of radiological COCs present, the field crew returned to this CAS on November 7 and 8, 2003, to conduct step-out sampling. Seven samples were collected between 12.5 and $17 \mathrm{ft} \mathrm{bgs} \mathrm{at} \mathrm{locations} \mathrm{adjacent} \mathrm{to} \mathrm{location} \mathrm{B02} \mathrm{at} \mathrm{the} \mathrm{septic}$ tank (i.e., B23, B24, B25, and B26). Six subsurface samples were also collected between 10.5 and $15.0 \mathrm{ft}$ bgs at locations B28, B29, and B30 adjacent to B04 at the distribution box. The ROTC No. 1 to the CAIP has changed the PALs for Pu-238 and Pu-239 from $0.05 \mathrm{pCi} / \mathrm{g}$ and $0.106 \mathrm{pCi} / \mathrm{g}$ to $7.87 \mathrm{pCi} / \mathrm{g}$ and $7.62 \mathrm{pCi} / \mathrm{g}$, respectively; therefore, eliminating locations B02, B04, and B07 as areas of concern for $\mathrm{Pu}-238$. However, Location B06 remains a location of concern because $\mathrm{Pu}-239$ is present at a concentration greater than the new PAL.

\section{A.4.2.5 Waste Characterization}

The following sections discuss the waste characterization sampling conducted at CAS 03-59-02. The contents of the septic tank were sampled in accordance with the CAIP (NNSA/NSO, 2003).

\section{A.4.2.5.1 Waste Characterization Sampling}

Waste characterization activities conducted at CAS 03-59-02 included visual assessment, video mole survey, radiological survey, photodocumentation, and waste characterization sampling of the septic tank contents. 
The septic tank is situated approximately $3.5 \mathrm{ft}$ bgs and the overlying soil had to be excavated to allow access. Each chamber of the tank could be accessed from a manhole at each end of the tank and each chamber was sampled for waste characterization.

Two liquid samples were initially collected from the septic tank (one from the effluent chamber and one from the influent chamber). Inspection of the tanks revealed that there was about $4 \mathrm{ft}$ of liquid in each chamber of the tank. When initially collected, the samples appeared to be liquid only; however, when the samples arrived to the laboratory, they had separated into three phases (i.e., liquid, sludge, and sediment). The laboratory separated each sample (516B501 and 516B502) into the three phases and analyzed each phase. Each phase was assigned a unique sample identifier $(516 \mathrm{~B} 501 \mathrm{~L}$, 516B501S, 516B501SL, 516B502L, 516B502S, 516B502SL). The volume of solids was not adequate for the laboratory to conduct all the appropriate analyses to make waste disposal decisions; therefore, liquid and solid samples were recollected from the septic tank on January 16, 2004. One liquid sample (516B503) and one solid sample (516B504) were collected from the effluent chamber, and one liquid sample (516B505) and one solid sample (516B506) were collected from the influent chamber. The distribution box was not sampled since visual inspection revealed that the box was empty. Samples were analyzed for the parameters identified in Table A.2-1.

Due to the presence of silver in samples collected from the photoprocessing dry well, the analytical suite was expanded to include TCLP silver analysis for environmental soil samples 516B025 and 516B026, which were previously collected. Toxic leaching characteristic procedure silver was detected in sample $516 \mathrm{~B} 025$ at a concentration of $0.13 \mathrm{mg} / \mathrm{L}$ using the TCLP method. The result is below the regulatory level of $5 \mathrm{mg} / \mathrm{L}$.

\section{A.4.2.6 Sample Analysis}

Investigation samples were analyzed for the CAIP-specified COPCs which included VOCs, SVOCs to include hydroquinone, RCRA metals, beryllium, aluminum, TPH (DRO/GRO), PCBs, Pu, Sr-90, tritium, and gamma-emitting radionuclides. Waste characterization samples (516B501 and 516B502) were initially analyzed for VOCs, SVOCs, RCRA metals, beryllium, TPH (DRO/GRO), PCBs, isotopic $\mathrm{Pu}, \mathrm{Sr}-90$, gross alpha/beta, tritium, and gamma-emitting radionuclides. The subsequent samples collected from the septic tank on January 16, 2004, were analyzed for VOCs, TCLP VOCs, SVOCs, TCLP SVOCs, RCRA metals, TCLP metals, beryllium, TPH (DRO/GRO), PCBs, isotopic 
$\mathrm{Pu}, \mathrm{Sr}-90$, gross alpha/beta, tritium, and gamma-emitting radionuclides. Select results from 516B501 and 516B502 were superseded by the results from select duplicate analyses of samples 516B503, 516504, 516505, and 516506. The analytical parameters and laboratory methods used to analyze the investigation samples are listed in Table A.2-2. Table A.4-1 lists the specific analytical suite for CAS 03-59-02.

\section{A.4.3 Analytes Equal to or Greater than Minimum Reporting Limits}

Analytical results for the soil samples with concentrations equal to or greater than the MRLs or MDCs (NNSA/NSO, 2003) are summarized in the following sections. The organic and inorganic results were compared to the PALs identified in the CAIP and are a subset of the results that are equal to or greater than the MRLs. The radiological results were compared to the PALs listed in ROTC No.1 of the CAIP. Results greater than PALs or regulatory disposal limits are identified by bold text in the analytical tables. The complete data set is maintained in the project file as hard copy and in electronic format.

\section{A.4.3.1 Total Volatile Organic Compound Analytical Results for Soil Samples}

Total VOC analytical results for soil samples equal to or greater than the MRLs are reported in Table A.4-2. The methylene chloride concentrations are less than the PALs.

\section{A.4.3.2 Total Semivolatile Organic Compound Analytical Results for Soil Samples}

Total SVOCs were not detected at concentrations equal to or greater than the MRLs.

\section{A.4.3.3 Total Metal Analytical Results for Soil Samples}

Total RCRA metal analytical results for soil samples were equal to or greater than the MRLs are reported in Table A.4-3. The results for total RCRA metals are less than the PALs. Beryllium was included in the analysis but no beryllium was detected at concentrations equal to or greater than the MRLs. Samples collected from the photoprocessing dry well were also analyzed for aluminum but the results were less than the MRLs. 
Table A.4-2

Soil Sample Results for Total VOCs Equal to or Greater than

Minimum Reporting Limits at CAS 03-59-02

\begin{tabular}{|c|c|c|c|}
\hline \multirow{2}{*}{$\begin{array}{l}\text { Sample } \\
\text { Location }\end{array}$} & \multirow{2}{*}{$\begin{array}{l}\text { Sample } \\
\text { Number }\end{array}$} & \multirow{2}{*}{$\begin{array}{l}\text { Depth } \\
\text { (ft bgs) }\end{array}$} & Contaminants of Potential Concern $(\mu \mathrm{g} / \mathrm{kg})$ \\
\hline & & & Methylene Chloride \\
\hline \multicolumn{3}{|c|}{ Preliminary Action Level ${ }^{a}$} & 21,000 \\
\hline B08 & 516B015 & $7.0-8.0$ & $11(\mathrm{~B})$ \\
\hline B09 & 516B017 & $7.0-8.0$ & $11(\mathrm{~B})$ \\
\hline B10 & 516B018 & $7.0-8.0$ & $12(\mathrm{~B})$ \\
\hline B11 & 516B019 & $7.0-8.0$ & $11(\mathrm{~B})$ \\
\hline B13 & $516 \mathrm{~B} 022$ & $7.0-8.0$ & $12(\mathrm{~B})$ \\
\hline
\end{tabular}

aU.S. Environmental Protection Agency, Region 9 Preliminary Remediation Goals (PRGs) (EPA, 2002)

$\mathrm{ft}$ bgs $=$ Feet below ground surface

$\mu \mathrm{g} / \mathrm{kg}=$ Micrograms per kilogram

$B=$ Analyte found in both sample and associated blank

\section{A.4.3.4 Total Petroleum Hydrocarbon Analytical Results for Soil Samples}

Total petroleum hydrocarbon concentrations for soil samples equal to or greater than the MRLs are reported in Table A.4-4. The two TPH-DRO concentrations detected were less that the PAL.

\section{A.4.3.5 Polychlorinated Biphenyl Analytical Results for Soil Samples}

Polychlorinated biphenyls were not detected at concentrations equal to or greater than the MRLs.

\section{A.4.3.6 Gamma Spectroscopy Analytical Results for Soil Samples}

Gamma spectroscopy results for soil samples equal to or greater than MDCs are listed in Table A.4-5. All gamma spectroscopy concentrations were less than the PALs.

\section{A.4.3.7 Isotopic Plutonium Analytical Results for Soil Samples}

Isotopic plutonium concentrations for soil samples equal to or greater than MDCs are listed in Table A.4-6. Sample 516B012 was collected between 5.5 and $6.5 \mathrm{ft}$ at location B06 and had a Pu-238 concentration of $7.3 \pm 1.1 \mathrm{pCi} / \mathrm{g}$. A conservative evaluation of the results by adding the uncertainty to 
Table A.4-3

Soil Sample Results for Total Metals Equal to or Greater than the Minimum Reporting Limits at CAS 03-59-02 (Page 1 of 2 )

\begin{tabular}{|c|c|c|c|c|c|c|c|c|c|}
\hline \multirow{2}{*}{$\begin{array}{l}\text { Sample } \\
\text { Location }\end{array}$} & \multirow{2}{*}{$\begin{array}{l}\text { Sample } \\
\text { Number }\end{array}$} & \multirow{2}{*}{$\begin{array}{c}\text { Depth } \\
\text { (ft bgs) }\end{array}$} & \multicolumn{7}{|c|}{ Contaminants of Potential Concern (mg/kg) } \\
\hline & & & Aluminum & Arsenic & Barium & Beryllium & Chromium & Lead & Silver \\
\hline \multicolumn{3}{|c|}{ Preliminary Action Levels } & $100,000^{a}$ & $23^{b}$ & $67,000^{\mathrm{a}}$ & $1,900^{\mathrm{a}}$ & $450^{a}$ & $750^{\mathrm{a}}$ & $5,100^{a}$ \\
\hline \multirow{2}{*}{ B01 } & 516B001 & $4.0-5.0$ & 12,000 & 6 & 170 & 1.1 & $\overline{8.4}$ & 12 & 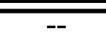 \\
\hline & 516B002 & $9.0-10.0$ & 9,400 & 4.8 & 140 & 0.87 & 7.6 & 17 & -- \\
\hline \multirow{2}{*}{ B02 } & 516B003 & $4.0-5.0$ & 10,000 & 4.4 & 150 & 0.89 & 6.7 & 11 & -- \\
\hline & 516B004 & $9.0-10.0$ & 11,000 & 4.2 & 160 & 0.98 & 6.4 & 9.9 & -- \\
\hline \multirow{2}{*}{ B03 } & 516B005 & $4.0-5.0$ & 8,000 & 3.7 & 170 & 0.69 & 5 & 13 & -- \\
\hline & 516B006 & $7.0-8.0$ & 10,000 & 4.1 & 130 & 0.97 & 6.1 & 11 & -- \\
\hline \multirow{2}{*}{ B04 } & 516B007 & $4.0-5.0$ & 8,300 & 4.8 & 140 & 0.7 & 8.3 & 9.4 & -- \\
\hline & 516B008 & $7.0-8.0$ & 11,000 & 4.1 & 140 & 1 & 6.4 & 10 & -- \\
\hline \multirow{2}{*}{ B05 } & 516B009 & $6.0-7.0$ & 6,600 & 3.3 & 110 & 0.59 & 5.1 & 11 & 36 \\
\hline & 516B010 & $9.5-10.5$ & 8,700 & 4.1 & 120 & 0.76 & 5.7 & 9.5 & 5.9 \\
\hline \multirow{3}{*}{ B06 } & 516B011 & $5.5-6.5$ & -- & 4.1 & 140 & 0.76 & 5.8 & 11 & -- \\
\hline & 516B012 & $5.5-6.5$ & -- & 4.1 & 140 & 0.78 & 5.9 & 10 & -- \\
\hline & 516B013 & $8.5-9.5$ & -- & 3.5 & 100 & 0.67 & 5.7 & 7.9 & -- \\
\hline B07 & 516B014 & $5.5-6.5$ & -- & 4.4 & 140 & 0.77 & 6 & 9.6 & -- \\
\hline \multirow{2}{*}{ B08 } & 516B015 & $7.0-8.0$ & 5,700 & 3.5 & 89 & 0.54 & 4.7 & 8 & -- \\
\hline & 516B016 & $10.5-11.5$ & -- & 2.6 & 91 & -- & 4.8 & 8.2 & -- \\
\hline B09 & 516B017 & $7.0-8.0$ & -- & 3.4 & 120 & 0.85 & 5.6 & 8.8 & 33 \\
\hline B10 & 516B018 & $7.0-8.0$ & -- & 4.1 & 140 & 0.8 & 6 & 11 & -- \\
\hline \multirow{2}{*}{ B11 } & 516B019 & $7.0-8.0$ & -- & 4.4 & 130 & 0.95 & 7.4 & 10 & -- \\
\hline & 516B020 & $10.5-11.5$ & -- & 4.4 & 120 & 0.89 & 6 & 9.8 & -- \\
\hline B12 & 516B021 & $7.0-8.0$ & -- & 4.2 & 130 & 0.78 & 6.3 & 10 & -- \\
\hline B13 & 516B022 & $7.0-8.0$ & -- & 3.4 & 120 & 0.82 & 5.8 & 9.8 & 39 \\
\hline B14 & 516B023 & $7.0-8.0$ & -- & 3.3 & 85 & $0.53(\mathrm{~B})$ & 3.7 & 12 & -- \\
\hline B15 & 516B024 & $7.0-8.0$ & -- & 4.1 & 130 & 0.81 & 6.3 & 9.6 & -- \\
\hline \multirow{2}{*}{ B16 } & 516B025 & $12.0-13.0$ & 9,600 & 5 & 140 & 0.9 & $8.6(\mathrm{~J})$ & 8.6 & 100 \\
\hline & 516B026 & $16.0-17.0$ & 12,000 & 5.6 & 270 & 1.1 & $8.3(\mathrm{~J})$ & 11 & 110 \\
\hline
\end{tabular}


Table A.4-3

Soil Sample Results for Total Metals Equal to or Greater than the Minimum Reporting Limits at CAS 03-59-02 (Page 2 of 2 )

\begin{tabular}{|c|c|c|c|c|c|c|c|c|c|}
\hline \multirow{2}{*}{$\begin{array}{l}\text { Sample } \\
\text { Location }\end{array}$} & \multirow{2}{*}{$\begin{array}{l}\text { Sample } \\
\text { Number }\end{array}$} & \multirow{2}{*}{$\begin{array}{c}\text { Depth } \\
\text { (ft bgs) }\end{array}$} & \multicolumn{7}{|c|}{ Contaminants of Potential Concern (mg/kg) } \\
\hline & & & Aluminum & Arsenic & Barium & Beryllium & Chromium & Lead & Silver \\
\hline \multicolumn{3}{|c|}{ Preliminary Action Levels } & $100,000^{\mathrm{a}}$ & $23^{b}$ & $67,000^{\mathrm{a}}$ & $1,900^{\mathrm{a}}$ & $450^{\mathrm{a}}$ & $750^{a}$ & $5,100^{\mathrm{a}}$ \\
\hline \multirow{2}{*}{ B17 } & $516 \mathrm{~B} 027$ & $12.0-13.0$ & 9,200 & 2.8 & 150 & 0.81 & $4.8(\mathrm{~J})$ & $\overline{6}$ & 25 \\
\hline & 516B028 & $16.0-17.0$ & 12,000 & 8.9 & 180 & 1.2 & $8(\mathrm{~J})$ & 11 & 15 \\
\hline \multirow{2}{*}{ B18 } & 516B029 & $12.0-13.0$ & 8,900 & 2.6 & 180 & 0.8 & $6.8(\mathrm{~J})$ & 6.4 & 30 \\
\hline & 516B030 & $16.0-17.0$ & 11,000 & 4.7 & 190 & 0.98 & $8.6(\mathrm{~J})$ & 10 & 58 \\
\hline \multirow{3}{*}{ B19 } & 516B031 & $12.0-13.0$ & 9,700 & 3.8 & 160 & 0.87 & 6 & 9.2 & -- \\
\hline & 516B032 & $12.0-13.0$ & 9,800 & 4.1 & 150 & 0.89 & 6.2 & 10 & -- \\
\hline & 516B033 & $16.0-17.0$ & 12,000 & 5.5 & 160 & 1.1 & 6.5 & 9.6 & $\overline{--}$ \\
\hline \multirow{3}{*}{ B20 } & 516B034 & $6.0-7.0$ & 7,900 & 4.1 & 110 & 0.71 & 5.6 & 8.6 & 1.1 \\
\hline & 516B035 & $10.0-11.00$ & 12,000 & 4.4 & 150 & 1.2 & 6.9 & 12 & 3.1 \\
\hline & 516B036 & $17.0-18.0$ & 11,000 & 6 & 150 & 1.1 & 7.5 & 10 & 2.5 \\
\hline \multirow{3}{*}{ B21 } & 516B037 & $26.0-27.0$ & 8,100 & 3.4 & 170 & 0.71 & 4.2 & 12 & $\overline{--}$ \\
\hline & 516B038 & $42.0-43.0$ & 4,100 & 4.5 & 80 & -- & 3.7 & 4.5 & -- \\
\hline & 516B039 & $48.0-49.0$ & 14,000 & 4.9 & 170 & 1.2 & 6.8 & 13 & -- \\
\hline \multirow{2}{*}{ B22 } & 516B040 & $42.0-43.0$ & 11,000 & 4.8 & 130 & 1 & 9.4 & 11 & -- \\
\hline & 516B041 & $48.0-49.0$ & 13,000 & 4.7 & 180 & 1.1 & 6.1 & 9.7 & -- \\
\hline
\end{tabular}

U.S. Environmental Protection Agency, Region 9 Preliminary Remediation Goals (PRGs) (EPA, 2002)

Based on the background concentrations for metals. Background is considered the mean plus two times the standard deviation for sediment samples collected by the Nevada Bureau of Mines and Geology throughout the Nevada Test and Training Range (NBMG, 1998; Moore, 1999).

$\mathrm{ft}$ bgs $=$ Feet below ground surface

$\mathrm{J}=$ Estimated value. Serial dilution \%D outside control limits. Matrix effects may exist.

$\mathrm{mg} / \mathrm{kg}=$ Milligrams per kilogram

-- = Not detected at concentrations equal to or greater than minimum reporting limits 
Table A.4-4

\section{Soil Sample Results for TPH-DRO Equal to or Greater than Minimum Reporting Limits at CAS 03-59-02}

\begin{tabular}{|c|c|c|c|}
\hline \multirow{2}{*}{$\begin{array}{c}\text { Sample } \\
\text { Location }\end{array}$} & $\begin{array}{c}\text { Sample } \\
\text { Number }\end{array}$ & $\begin{array}{c}\text { Depth } \\
\text { (ft bgs) }\end{array}$ & Contaminants of Potential Concern (mg/kg) \\
\cline { 3 - 4 } & \multicolumn{2}{|c|}{ Preliminary Action Levels ${ }^{\mathrm{a}}$} & 100 \\
\hline \hline B02 & $516 \mathrm{~B} 003$ & $4.0-5.0$ & $7.3(\mathrm{H})$ \\
\hline $\mathrm{B} 15$ & $516 \mathrm{~B} 024$ & $7.0-8.0$ & $26(\mathrm{H})$ \\
\hline
\end{tabular}

aNevada Administrative Code, "Water Controls" (NAC, 2003)

$\mathrm{ft}$ bgs $=$ Feet below ground surface

$\mathrm{mg} / \mathrm{kg}=$ Milligrams per kilogram

$\mathrm{H}=$ The fuel pattern was in the heavier end of the retention time window for the analyte of interest.

the reported result $(7.3 \mathrm{pCi} / \mathrm{g}+1.1=8.4 \mathrm{pCi} / \mathrm{g})$ exceeds the $\mathrm{PAL}$ of $7.62 \mathrm{pCi} / \mathrm{g}$ for plutonium-239 (NCRP, 1999).

\section{A.4.3.8 Strontium-90 Analytical Results for Soil Samples}

Strontium-90 was not detected at concentrations equal to or greater than the MDCs.

\section{A.4.3.9 Waste Characterization Sample Results}

The analytical results from the septic tank samples equal to or greater than the MRLs or MDCs are presented in Table A.4-7. Two liquid samples were collected from inside the septic tank (one from the effluent chamber [516B501] and one from the influent chamber [516B502]). The samples were analyzed for VOCs, SVOCs, RCRA metals, beryllium, TPH (DRO/GRO), PCBs, tritium, and gross alpha-beta. The TPH-DRO concentration in the solid sample $516 \mathrm{~B} 501 \mathrm{~S}$ was $7,900 \mathrm{mg} / \mathrm{kg}$ requiring disposal of this material as hydrocarbon waste.

The volume of solid material initially collected from the septic tank was inadequate for the analysis of TCLP metals; therefore, the analysis was conducted on the additional septic tank samples collected on January 16, 2004. Gross alpha and gross beta was detected in sample 516B503 at $104 \pm 20$ and $193 \pm 34 \mathrm{pCi} / \mathrm{L}$, respectively. These values exceed the acceptable levels for disposal in the NTS sewage lagoons. Therefore, the liquid will have to be solidified and disposed of as industrial waste. 
Table A.4-5

Soil Sample Results for Gamma-Emitting Radionuclides Equal to or Greater than Minimum Detectable Concentrations at CAS 03-59-02

\begin{tabular}{|c|c|c|c|c|c|c|c|c|}
\hline \multirow{2}{*}{$\begin{array}{l}\text { Sample } \\
\text { Location }\end{array}$} & \multirow{2}{*}{$\begin{array}{l}\text { Sample } \\
\text { Number }\end{array}$} & \multirow{2}{*}{$\begin{array}{c}\text { Depth } \\
\text { (ft bgs) }\end{array}$} & \multicolumn{6}{|c|}{ Contaminants of Potential Concern (pCi/g) } \\
\hline & & & Actinium-228 & Bismuth-214 & Cesium-137 & Lead-212 & Lead-214 & Thallium-208 \\
\hline \multicolumn{3}{|c|}{ Preliminary Action Levels } & $15^{\mathrm{a}}$ & $15^{\mathrm{a}}$ & $7.30^{b}$ & $15^{\mathrm{a}}$ & $15^{\mathrm{a}}$ & $15^{a}$ \\
\hline B01 & 516B001 & $4.0-5.0$ & $1.72 \pm 0.45$ & $1.01 \pm 0.28$ & $\overline{---}$ & $1.56 \pm 0.34$ & $1.03 \pm 0.25$ & $0.63 \pm 0.18$ \\
\hline B03 & 516B006 & $7.0-8.0$ & $1.88 \pm 0.44$ & $1.04 \pm 0.28$ & $0.25 \pm 0.1$ & $2.02 \pm 0.39$ & $1.05 \pm 0.24$ & $0.48 \pm 0.14$ \\
\hline B05 & 516B009 & $6.0-7.0$ & $1.6 \pm 0.42$ & $0.95 \pm 0.27$ & -- & $1.78 \pm 0.36$ & $0.82 \pm 0.22$ & $0.51 \pm 0.15$ \\
\hline B06 & 516B013 & $8.5-9.5$ & $1.43 \pm 0.37$ & $0.9 \pm 0.24$ & -- & $1.53 \pm 0.32$ & $0.86 \pm 0.22$ & $0.56 \pm 0.15$ \\
\hline \multirow{2}{*}{ B11 } & 516B019 & $7.0-8.0$ & $2.04 \pm 0.46$ & $0.82 \pm 0.22$ & -- & $1.88 \pm 0.37$ & $1.05 \pm 0.24$ & $0.6 \pm 0.15$ \\
\hline & 516B020 & $10.5-11.5$ & $1.78 \pm 0.43$ & $0.75 \pm 0.25$ & -- & $2.03 \pm 0.4$ & $0.85 \pm 0.22$ & $0.54 \pm 0.15$ \\
\hline B14 & 516B023 & $7.0-8.0$ & -- & -- & -- & $1.83 \pm 0.43$ & $0.89 \pm 0.29$ & $0.51 \pm 0.19$ \\
\hline B16 & 516B026 & $16.0-17.0$ & -- & -- & -- & $1.78 \pm 0.5$ & $1.15 \pm 0.42$ & -- \\
\hline B18 & $516 \mathrm{~B} 030$ & $16.0-17.0$ & -- & -- & -- & $1.35 \pm 0.43$ & $1.25 \pm 0.42$ & $0.68 \pm 0.29$ \\
\hline B19 & 516B033 & $16.0-17.0$ & -- & -- & -- & $1.86 \pm 0.48$ & $1.15 \pm 0.39$ & $\begin{array}{l}- \\
-\end{array}$ \\
\hline \multirow{3}{*}{ B20 } & 516B034 & $6.0-7.0$ & $1.68 \pm 0.46$ & $0.79 \pm 0.27$ & -- & $1.72 \pm 0.37$ & $0.96 \pm 0.25$ & $0.68 \pm 0.18$ \\
\hline & 516B035 & $10.0-11.00$ & $1.97 \pm 0.5$ & $1.13 \pm 0.32$ & -- & $1.75 \pm 0.39$ & $1.07 \pm 0.26$ & $0.76 \pm 0.2$ \\
\hline & 516B036 & $17.0-18.0$ & $1.5 \pm 0.41$ & $1.02 \pm 0.27$ & -- & $2.18 \pm 0.43$ & $1.09 \pm 0.26$ & $0.64 \pm 0.17$ \\
\hline \multirow{3}{*}{ B21 } & 516B037 & $26.0-27.0$ & $1.54 \pm 0.34$ & $0.71 \pm 0.2$ & -- & $1.55 \pm 0.29$ & $0.94 \pm 0.2$ & $0.48 \pm 0.11$ \\
\hline & 516B038 & $42.0-43.0$ & $0.6 \pm 0.21$ & $0.52 \pm 0.17$ & -- & $0.66 \pm 0.17$ & $0.5 \pm 0.14$ & $0.205 \pm 0.081$ \\
\hline & 516B039 & $48.0-49.0$ & $2.24 \pm 0.62$ & $0.94 \pm 0.33$ & -- & $1.65 \pm 0.38$ & $1.04 \pm 0.26$ & $0.68 \pm 0.19$ \\
\hline \multirow{2}{*}{ B22 } & $516 \mathrm{~B} 040$ & $42.0-43.0$ & $1.64 \pm 0.45$ & $0.82 \pm 0.27$ & -- & $1.72 \pm 0.38$ & $0.83 \pm 0.23$ & $0.64 \pm 0.18$ \\
\hline & 516B041 & $48.0-49.0$ & $2.11 \pm 0.51$ & $0.96 \pm 0.29$ & -- & $2.05 \pm 0.42$ & $0.97 \pm 0.25$ & $0.54 \pm 0.15$ \\
\hline
\end{tabular}

${ }^{2}$ Taken from the generic guidelines for residual concentrations of Radium-226, Radium-228, Thorium-230, and Thorium-232 as found in Chapter IV of DOE Order 5400.5, Change 2, "Radiation Protection of the Public and Environment." The PAL for these isotopes is specified as $5 \mathrm{pCi} / \mathrm{g}$ averaged over the first 15 centimeters of soil and $15 \mathrm{pCi} / \mathrm{g}$ for deeper soils. For purposes of this document, 15 centimeters is assumed to be equivalent to $0.5 \mathrm{ft}$ (6 in.) (DOE, 1993).

${ }^{\mathrm{b}}$ Taken from the Construction, Commercial, Industrial land use scenario in Table 2.1 of the NCRP Report No. 129, Recommended Screening Limits for Contaminated Surface Soil and Review Factors Relevant to Site-Specific Studies (NCRP, 1999). The values provided in this source document were scaled to a 15-mrem per year dose.

$\mathrm{ft}$ bgs $=$ Feet below ground surface

$\mathrm{pCi} / \mathrm{g}=$ Picocuries per gram

-- = Not detected at concentrations equal to or greater than minimum detectable concentrations 
Table A.4-6

\section{Soil Sample Results for Isotopic Plutonium Equal to or Greater than Minimum Detectable Concentrations at CAS 03-59-02}

\begin{tabular}{|c|c|c|c|c|}
\hline \multirow{2}{*}{$\begin{array}{l}\text { Sample } \\
\text { Location }\end{array}$} & \multirow{2}{*}{$\begin{array}{l}\text { Sample } \\
\text { Number }\end{array}$} & \multirow{2}{*}{$\begin{array}{c}\text { Depth } \\
\text { (ft bgs) }\end{array}$} & \multicolumn{2}{|c|}{ Contaminants of Potential Concern $(\mathrm{pCi} / \mathrm{g})$} \\
\hline & & & Plutonium-238 & Plutonium-239 \\
\hline \multicolumn{3}{|c|}{ Preliminary Action Levels ${ }^{a}$} & 7.78 & 7.62 \\
\hline B01 & 516B002 & $9.0-10.0$ & -- & $0.238 \pm 0.073$ \\
\hline \multirow{2}{*}{ B02 } & $516 \mathrm{~B} 003$ & $4.0-5.0$ & -- & $0.62 \pm 0.13$ \\
\hline & 516B004 & $9.0-10.0$ & -- & $0.28 \pm 0.08$ \\
\hline B03 & 516B005 & $4.0-5.0$ & -- & $0.056 \pm 0.03$ \\
\hline B04 & 516B008 & $7.0-8.0$ & -- & $0.323 \pm 0.082$ \\
\hline B05 & 516B010 & $9.5-10.5$ & -- & $0.052 \pm 0.029$ \\
\hline \multirow{2}{*}{ B06 } & 516B011 & $5.5-6.5$ & $1.92 \pm 0.32$ & $7.3 \pm 1.1$ \\
\hline & 516B012 & $5.5-6.5$ & $1.38 \pm 0.24$ & $3.92 \pm 0.6$ \\
\hline B07 & 516B014 & $5.5-6.5$ & $0.078 \pm 0.035$ & $0.48 \pm 0.11$ \\
\hline B12 & 516B021 & $7.0-8.0$ & -- & $0.08 \pm 0.036$ \\
\hline B15 & 516B024 & $7.0-8.0$ & -- & $0.223 \pm 0.062$ \\
\hline
\end{tabular}

Note: Samples exceeding PALs are in bold.

${ }^{a}$ Taken from the Construction, Commercial, Industrial land use scenario in Table 2.1 of the NCRP Report No. 129, Recommended Screening Limits for Contaminated Surface Soil and Review Factors Relevant to Site-Specific Studies (NCRP, 1999). The values provided in this source document were scaled to a 15-mrem per year dose.

$\mathrm{ft}$ bgs $=$ Feet below ground surface

$\mathrm{pCi} / \mathrm{g}=$ Picocuries per gram

-- = Not detected at concentrations equal to or greater than minimum detectable concentrations

The TCLP results for sample 516B506 (solid material from the influent chamber) showed the chlorinated compounds 1,1-dichloroethene; 1,2-dichloroethane; and trichloroethene at concentrations of $6,0.96$, and $4 \mathrm{mg} / \mathrm{L}$, respectively. These values exceed the regulatory levels of $0.7,0.5$, and $0.5 \mathrm{mg} / \mathrm{L}$, respectively (CFR, 2003).

\section{A.4.4 Contaminants of Concern}

Plutonium-239 was the only COC identified in the soil during the CAI at CAS 03-59-02. This contaminant was detected at location B06 between 5.5 and $6.5 \mathrm{ft}$ bgs at the interface between the leachfield gravel and the native soil. The results show a concentration that exceeded the PAL. 
Table A.4-7

Septic Tank Sample Results for CAS 03-59-02

(Page 1 of 3 )

\begin{tabular}{|c|c|c|c|c|}
\hline $\begin{array}{l}\text { Sample } \\
\text { Number }\end{array}$ & $\begin{array}{c}\text { Sample } \\
\text { Matrix }\end{array}$ & Parameter & Result & Units \\
\hline \multirow{6}{*}{$\begin{array}{c}\text { 516B501 } \\
\text { (Effluent } \\
\text { Chamber) }\end{array}$} & Liquid & 1,4-Dichlorobenzene & $\overline{1,800(\mathrm{~J})^{\mathrm{a}}}$ & $\mu \mathrm{g} / \mathrm{L}$ \\
\hline & Liquid & 1,1-Dichloroethane & $12,000(J)^{a}$ & $\mu \mathrm{g} / \mathrm{L}$ \\
\hline & Liquid & Cis 1,2-Dichloroethene & $1,300(\mathrm{~J})^{\mathrm{a}}$ & $\mu \mathrm{g} / \mathrm{L}$ \\
\hline & Liquid & Gasoline-Range Organics & $3(J)^{b}$ & $\mathrm{mg} / \mathrm{L}$ \\
\hline & Liquid & Toluene & $840(\mathrm{~J})^{\mathrm{a}}$ & $\mu \mathrm{g} / \mathrm{L}$ \\
\hline & Liquid & P-Isopropyltoluene & $1,100(\mathrm{~J})^{\mathrm{c}}$ & $\mu \mathrm{g} / \mathrm{L}$ \\
\hline \multirow{2}{*}{$\begin{array}{c}\text { 516B501L } \\
\text { (Effluent } \\
\text { Chamber) }\end{array}$} & Liquid & 1,4-Dichlorobenzene & 16 & $\mu g / L$ \\
\hline & Liquid & Diesel-Range Organics & $2.4(L, Z)$ & $\mathrm{mg} / \mathrm{L}$ \\
\hline \multirow{10}{*}{$\begin{array}{c}\text { 516B501S } \\
\text { (Effluent } \\
\text { Chamber) }\end{array}$} & Solid & Lead & $290(\mathrm{~J})^{\mathrm{d}}$ & $\mathrm{mg} / \mathrm{kg}$ \\
\hline & Solid & Silver & $29(\mathrm{~J})^{\mathrm{e}}$ & $\mathrm{mg} / \mathrm{kg}$ \\
\hline & Solid & Arsenic & 26 & $\mathrm{mg} / \mathrm{kg}$ \\
\hline & Solid & Barium & $430(\mathrm{~J})^{\mathrm{e}}$ & $\mathrm{mg} / \mathrm{kg}$ \\
\hline & Solid & Cadmium & $32(J)^{d}$ & $\mathrm{mg} / \mathrm{kg}$ \\
\hline & Solid & Chromium & 97 & $\mathrm{mg} / \mathrm{kg}$ \\
\hline & Solid & Selenium & 7.1 & $\mathrm{mg} / \mathrm{kg}$ \\
\hline & Solid & Mercury & $13(\mathrm{~J})^{\mathrm{e}}$ & $\mathrm{mg} / \mathrm{kg}$ \\
\hline & Solid & Diesel-Range Organics & 7,900 (L, H, Z) & $\mathrm{mg} / \mathrm{kg}$ \\
\hline & Solid & Aroclor 1254 & 530 & $\mu g / L$ \\
\hline \multirow{19}{*}{$\begin{array}{l}\text { 516B502 } \\
\text { (Influent } \\
\text { Chamber) }\end{array}$} & Liquid & 1,1-Dichloroethene & 110 & $\mu \mathrm{g} / \mathrm{L}$ \\
\hline & Liquid & 1,1,2-Trichloroethane & 20 & $\mu g / L$ \\
\hline & Liquid & 1,2,4-Trimethylbenzene & 7.5 & $\mu \mathrm{g} / \mathrm{L}$ \\
\hline & Liquid & 1,4-Dichlorobenzene & 49 & $\mu \mathrm{g} / \mathrm{L}$ \\
\hline & Liquid & 1,2-Dichloropropane & 26 & $\mu \mathrm{g} / \mathrm{L}$ \\
\hline & Liquid & 1,2-Dichloroethane & 82 & $\mu \mathrm{g} / \mathrm{L}$ \\
\hline & Liquid & Tetrachloroethene & 160 & $\mu \mathrm{g} / \mathrm{L}$ \\
\hline & Liquid & 1,1-Dichloroethane & 3,500 & $\mu \mathrm{g} / \mathrm{L}$ \\
\hline & Liquid & Naphthalene & 32 & $\mu \mathrm{g} / \mathrm{L}$ \\
\hline & Liquid & 1,1,1-Trichloroethane & 46,000 & $\mu \mathrm{g} / \mathrm{L}$ \\
\hline & Liquid & Toluene & 160 & $\mu \mathrm{g} / \mathrm{L}$ \\
\hline & Liquid & Methylene Chloride & $330(\mathrm{~B})$ & $\mu \mathrm{g} / \mathrm{L}$ \\
\hline & Liquid & Trichloroethene & 210 & $\mu g / L$ \\
\hline & Liquid & 2-Butanone & 21 & $\mu \mathrm{g} / \mathrm{L}$ \\
\hline & Liquid & Chloroform & 5.9 & $\mu \mathrm{g} / \mathrm{L}$ \\
\hline & Liquid & Cis-1,2-Dichloroethene & 60 & $\mu \mathrm{g} / \mathrm{L}$ \\
\hline & Liquid & Trans-1,2-Dichloroethene & 12 & $\mu \mathrm{g} / \mathrm{L}$ \\
\hline & Liquid & Trichlorotrifluoroethane & 570 & $\mu g / L$ \\
\hline & Liquid & Gasoline-Range Organics & $0.34(G)$ & $\mathrm{mg} / \mathrm{L}$ \\
\hline
\end{tabular}


Table A.4-7

Septic Tank Sample Results for CAS 03-59-02

(Page 2 of 3 )

\begin{tabular}{|c|c|c|c|c|}
\hline $\begin{array}{l}\text { Sample } \\
\text { Number }\end{array}$ & $\begin{array}{c}\text { Sample } \\
\text { Matrix }\end{array}$ & Parameter & Result & Units \\
\hline \multirow{8}{*}{$\begin{array}{c}\text { 516B502L } \\
\text { (Influent } \\
\text { Chamber) }\end{array}$} & Liquid & Diesel-Range Organics & $6.6(L, Z)$ & $\mathrm{mg} / \mathrm{L}$ \\
\hline & Liquid & Benzyl Alcohol & $110(\mathrm{~J})^{f}$ & $\overline{\mu g / L}$ \\
\hline & Liquid & Bis(2-Chloroisopropyl)Ether & $110(\mathrm{~J})^{f}$ & $\mu \mathrm{g} / \mathrm{L}$ \\
\hline & Liquid & Phenol & $200(J)^{f}$ & $\mu \mathrm{g} / \mathrm{L}$ \\
\hline & Liquid & N-Nitroso-Di-N-Propylamine & $110(J)^{f}$ & $\mu \mathrm{g} / \mathrm{L}$ \\
\hline & Liquid & 2-Methylphenol & $110(\mathrm{~J})^{f}$ & $\mu \mathrm{g} / \mathrm{L}$ \\
\hline & Liquid & 1,2-Dichlorobenzene & $110(\mathrm{~J})^{f}$ & $\mu \mathrm{g} / \mathrm{L}$ \\
\hline & Liquid & 4-Methylphenol & $9,600(\mathrm{~J})^{9}$ & $\mu g / L$ \\
\hline \multirow{18}{*}{$\begin{array}{c}\text { 516B502S } \\
\text { (Influent } \\
\text { Chamber) }\end{array}$} & Solid & Lead & $400(\mathrm{~J})^{\mathrm{e}}$ & $\mathrm{mg} / \mathrm{kg}$ \\
\hline & Solid & Silver & $16(\mathrm{~J})^{\mathrm{e}}$ & $\mathrm{mg} / \mathrm{kg}$ \\
\hline & Solid & Arsenic & 8.5 & $\mathrm{mg} / \mathrm{kg}$ \\
\hline & Solid & Barium & $400(J)^{\mathrm{h}}$ & $\mathrm{mg} / \mathrm{kg}$ \\
\hline & Solid & Cadmium & $21(J)^{d}$ & $\mathrm{mg} / \mathrm{kg}$ \\
\hline & Solid & Chromium & 86 & $\mathrm{mg} / \mathrm{kg}$ \\
\hline & Solid & Selenium & $3.2(\mathrm{~B})$ & $\mathrm{mg} / \mathrm{kg}$ \\
\hline & Solid & Mercury & $5.6(\mathrm{~J})^{\mathrm{b}}$ & $\mathrm{mg} / \mathrm{kg}$ \\
\hline & Solid & Diesel-Range Organics & $28,000(L, H, Z)$ & $\mathrm{mg} / \mathrm{kg}$ \\
\hline & Solid & 4-Methylphenol & 100,000 & $\mu \mathrm{g} / \mathrm{kg}$ \\
\hline & Solid & 1,4-Dichlorobenzene & 120,000 & $\mu \mathrm{g} / \mathrm{kg}$ \\
\hline & Solid & Bis(2-Ethylhexyl)Phthalate & $15,000(J)^{i}$ & $\mu \mathrm{g} / \mathrm{kg}$ \\
\hline & Solid & Pyrene & $69,000(\mathrm{~J})^{j}$ & $\mu \mathrm{g} / \mathrm{kg}$ \\
\hline & Solid & Benzo(G,H,I)Perylene & $15,000(J)^{i}$ & $\mu \mathrm{g} / \mathrm{kg}$ \\
\hline & Solid & Benzo(B)Fluoranthene & $15,000(J)^{i}$ & $\mu \mathrm{g} / \mathrm{kg}$ \\
\hline & Solid & Chrysene & $32,000(\mathrm{~J})^{i}$ & $\mu \mathrm{g} / \mathrm{kg}$ \\
\hline & Solid & Phenanthrene & 65,000 & $\mu \mathrm{g} / \mathrm{kg}$ \\
\hline & Solid & Naphthalene & 67,000 & $\mu \mathrm{g} / \mathrm{kg}$ \\
\hline \multirow{8}{*}{$\begin{array}{l}\text { 516B503 } \\
\text { (Effluent } \\
\text { Chamber) }\end{array}$} & Liquid & Lead & 0.096 & $\mathrm{mg} / \mathrm{L}$ \\
\hline & Liquid & Mercury & 0.0061 & $\mathrm{mg} / \mathrm{L}$ \\
\hline & Liquid & Gross Alpha & $104 \pm 20(M 3)$ & $\mathrm{pCi} / \mathrm{L}$ \\
\hline & Liquid & Gross Beta & $193 \pm 34(\mathrm{M} 3)$ & $\overline{\mathrm{pCi} / \mathrm{L}}$ \\
\hline & Liquid & Chromium & 0.044 & $\mathrm{mg} / \mathrm{L}$ \\
\hline & Liquid & Cadmium & 0.012 & $\mathrm{mg} / \mathrm{L}$ \\
\hline & Liquid & Barium & 0.96 & $\mathrm{mg} / \mathrm{L}$ \\
\hline & Liquid & Arsenic & 0.04 & $\mathrm{mg} / \mathrm{L}$ \\
\hline \multirow{3}{*}{$\begin{array}{c}\text { 516B504 } \\
\text { (Effluent } \\
\text { Chamber) }\end{array}$} & Soil & Lead-212 & $0.75 \pm 0.26(\mathrm{G})$ & $\mathrm{pCi} / \mathrm{g}$ \\
\hline & Soil & Thorium-234 & $5.8 \pm 1.4(J)^{\mathrm{k}}$ & $\mathrm{pCi} / \mathrm{g}$ \\
\hline & Soil & Aroclor 1254 & 450 & $\mu \mathrm{g} / \mathrm{kg}$ \\
\hline
\end{tabular}




\section{Table A.4-7 \\ Septic Tank Sample Results for CAS 03-59-02}

(Page 3 of 3 )

\begin{tabular}{|c|c|c|c|c|}
\hline $\begin{array}{l}\text { Sample } \\
\text { Number }\end{array}$ & $\begin{array}{c}\text { Sample } \\
\text { Matrix }\end{array}$ & Parameter & Result & Units \\
\hline \multirow{3}{*}{$\begin{array}{c}\text { 516B505 } \\
\text { (Effluent } \\
\text { Chamber) }\end{array}$} & Liquid & Gross Alpha & $6.1 \pm 2.3$ & $\overline{\mathrm{pCi} / \mathrm{L}}$ \\
\hline & Liquid & Gross Beta & $33.4 \pm 6.4(\mathrm{M} 3)$ & $\overline{\mathrm{pCi} / \mathrm{L}}$ \\
\hline & Liquid & Lead & 0.0052 & $\mathrm{mg} / \mathrm{L}$ \\
\hline \multirow{7}{*}{$\begin{array}{c}\text { 516B506 } \\
\text { (Influent } \\
\text { Chamber) }\end{array}$} & Soil & 3+4-Methylphenol & 1.5 & $\overline{\mathrm{mg} / \mathrm{L}}$ \\
\hline & Soil & 1,1-Dichloroethene & 6 & $\mathrm{mg} / \mathrm{L}$ \\
\hline & Soil & 1,2-Dichloroethane & 0.96 & $\overline{\mathrm{mg} / \mathrm{L}}$ \\
\hline & Soil & 2-Butanone & $0.21(\mathrm{~J})^{1}$ & $\mathrm{mg} / \mathrm{L}$ \\
\hline & Soil & Chloroform & $0.13(\mathrm{~J})^{1}$ & $\mathrm{mg} / \mathrm{L}$ \\
\hline & Soil & Tetrachloroethene & 0.65 & $\mathrm{mg} / \mathrm{L}$ \\
\hline & Soil & Trichloroethene & 4 (B) & $\mathrm{mg} / \mathrm{L}$ \\
\hline
\end{tabular}

Note: Sample results exceeding regulatory limits for disposal are in bold text.

amproper preservation/pH or not documented.

${ }^{b}$ Volatile/reactive sample vial contained headspace.

'Improper preservation/pH or not documented.

${ }^{\mathrm{d}}$ Matrix spike recovery outside control limits. Duplicate precision analysis (relative percent difference) outside control limits.

eDuplicate precision analysis (relative percent difference) outside control limits.

fSurrogates diluted out.

'Value exceeded linear/calibration range of instrument. The reported value is from the dilution run. Surrogates diluted out.

${ }^{\mathrm{h}}$ Matrix spike recovery outside control limits.

'Matrix effects may exist. Internal area response show extremely low count.

'Matrix effects may exist. Matrix spike recovery outside control limits, internal area response show extremely low count.

${ }^{k}$ Sample does not meet counting geometry requirements.

'Surrogate recovery exceeded the lower limits.

$\mu \mathrm{g} / \mathrm{L}=$ Micrograms per liter

$\mu \mathrm{g} / \mathrm{kg}=$ Micrograms per kilogram

$\mathrm{mg} / \mathrm{kg}=$ Milligrams per kilogram

$\mathrm{pCi} / \mathrm{g}=$ Picocuries per gram

$B=$ Analyte found in both sample and associated blank.

$\mathrm{G}=$ Sample density differs by more than $15 \%$ of LCS density.

$\mathrm{H}=$ The fuel pattern was in the heavier end of the retention time window for the analyte of interest.

$\mathrm{J}=$ Estimated value.

$L=$ Fuel pattern in the lighter end of retention time window.

$\mathrm{LT}=$ Result is less requested minimum detectable concentration, greater than specific minimum detectable concentration.

M3 = Requested MDC was not met, but the reported activity is greater than the reported MDL.

NA $=$ Not applicable

$Z=A$ significant fraction of the reported result did not resemble the patterns of the following petroleum hydrocarbon products:

Gasoline, JP-4, JP-8, diesel, mineral spirits, motor oil, Stoddard solvent, and Bunker C. 


\section{A.4.5 Nature and Extent of Contamination}

The concentration of the $\mathrm{Pu}-239$ contamination that exceeded the PAL is limited vertically between 5.5 and $6.5 \mathrm{ft}$ bgs. The radiological FSR for the sample collected did not indicate the presence of any other radionuclides exceeding FSLs. A duplicate sample analyzed from the same interval did not contain $\mathrm{Pu}-239$ at concentrations that were equal to or greater than the PAL. In addition, the sample (516B013) collected from 8.5 to $9.5 \mathrm{ft}$ bgs at location B06 did not contain $\mathrm{Pu}-239$ at a concentration greater than the PAL. Based on the limited vertical extent, relatively low concentrations, the FSR, step-out sampling, and a duplicate analysis, the $\mathrm{Pu}-239$ is considered to be limited in extent both laterally and vertically. It is estimated that the $\mathrm{Pu}-239$ contamination is likely limited to $10 \mathrm{ft}$ in the lateral direction.

\section{A.4.6 Revised Conceptual Site Model}

No variations in the conceptual site model were identified. 


\section{A.5.0 CAS 06-51-01, Sump and Piping}

Corrective Action Site 06-51-01 includes a sump and the associated piping running to the collection box adjacent to Building 660. The site is located in Well 3 Yard, immediately north of the water stand. Building 660 was used for the Animal Investigation Program conducted by the U.S. Public Health Service. Additional detail is provided in the CAIP (NNSA/NSO, 2003). This site includes approximately $275 \mathrm{ft}$ of VCP running between the collection box (CAS 06-51-03) and the outfall into the sump. The sump has been filled with soil (Figure A.4-1). Wastewater flowed from Building 660 through a discharge pipe running through the clean-out box in CAS 06-51-03 and continuing to the outfall at the sump.

\section{A.5.1 Corrective Action Investigation}

A total of 14 soil samples (including one duplicate) from 10 locations were collected during investigation activities conducted at CAS 06-51-01. Three locations D02, D03, and D05 were mistakenly numbered for CAS 06-59-03 and are actually located in CAS 06-51-01; therefore, are included in this discussion. Two water samples were submitted for QC purposes. One sample was collected for waste characterization purposes. These samples were analyzed for the parameters listed in Table A.5-1. Sample locations are shown in Figure A.5-1.

\section{A.5.1.1 Deviations}

There were no deviations from the investigation activities specified in the CAIP for CAS 06-51-01.

\section{A.5.2 Investigation Activities}

The following sections provide descriptions of the CAS-specific activities conducted to complete Phase I activities as outlined in the CAIP. The specific CAI activities conducted to satisfy the CAIP requirements at CAS 06-51-01 are described in Table A.2-1.

\section{A.5.2.1 Field Screening}

Soil samples were screened for VOCs, TPH, and alpha and beta/gamma radioactivity. The FSRs were compared to FSLs to guide subsequent sampling and analytical decisions. The VOC FSL was 
Table A.5-1

Samples Collected at CAS 06-51-01

\begin{tabular}{|c|c|c|c|c|c|c|c|c|c|}
\hline $\begin{array}{l}\text { Sample } \\
\text { Location }\end{array}$ & $\begin{array}{l}\text { Sample } \\
\text { Number }\end{array}$ & $\begin{array}{c}\text { Depth } \\
\text { (ft bgs) }\end{array}$ & $\begin{array}{l}\text { Sample } \\
\text { Matrix }\end{array}$ & Purpose & $\begin{array}{l}\text { Total } \\
\text { VOCs }\end{array}$ & $\begin{array}{c}\text { Total } \\
\text { SVOCs }\end{array}$ & $\begin{array}{c}\text { Total } \\
\text { RCRA } \\
\text { Metals } \\
\text { plus } \\
\text { Beryllium }\end{array}$ & $\begin{array}{c}\text { PCBs } \\
\text { and } \\
\text { TPH } \\
\text { DRO/GRO }\end{array}$ & $\begin{array}{l}\text { Gamma Spectroscopy, } \\
\text { Isotopic Plutonium, } \\
\text { and Strontium-90 }\end{array}$ \\
\hline \multirow{2}{*}{$\mathrm{C} 01$} & $516 \mathrm{C001}$ & $8-10$ & Soil & Environmental & $\bar{X}$ & $\bar{X}$ & $\mathrm{X}$ & $\bar{X}$ & $\bar{x}$ \\
\hline & $516 \mathrm{C} 002$ & $8-10$ & Soil & Duplicate of 516C001 & $\mathrm{x}$ & $\bar{x}$ & $\bar{x}$ & $\mathrm{x}$ & $\bar{x}$ \\
\hline \multirow{2}{*}{$\mathrm{C} 02$} & $516 \mathrm{C} 003$ & $8-10$ & Soil & Environmental & $\mathrm{X}$ & $\bar{x}$ & $\bar{x}$ & $\bar{x}$ & $\mathrm{X}$ \\
\hline & $516 \mathrm{C008}$ & $10-11$ & Soil & Environmental & $\bar{x}$ & $\bar{x}$ & $\bar{x}$ & $\bar{x}$ & -- \\
\hline $\mathrm{C03}$ & $516 \mathrm{C004}$ & $0-0.5$ & Soil & Environmental & $\bar{x}$ & $\bar{x}$ & $\bar{x}$ & $\bar{x}$ & $\bar{x}$ \\
\hline $\mathrm{C04}$ & $516 \mathrm{C} 005$ & $9-10$ & Soil & Environmental & $\bar{X}$ & $\mathrm{X}$ & $\mathrm{X}$ & $\mathrm{X}$ & $\mathrm{X}$ \\
\hline $\mathrm{C05}$ & $516 \mathrm{C006}$ & $9-10$ & Soil & Environmental & -- & -- & -- & -- & $\bar{x}$ \\
\hline \multirow{2}{*}{$\mathrm{C} 06$} & $516 \mathrm{C} 007$ & $6-7$ & Soil & Environmental & -- & -- & -- & -- & $\mathrm{x}$ \\
\hline & $516 \mathrm{C} 012$ & $7-8$ & Soil & Environmental & $\bar{X}$ & $\bar{x}$ & $\bar{x}$ & $\bar{x}$ & -- \\
\hline \multirow{2}{*}{$\mathrm{C} 07$} & $516 C 009$ & $8.5-9.5$ & Soil & Environmental & $x$ & $x$ & $x$ & $\mathrm{X}$ & -- \\
\hline & $516 \mathrm{C} 010$ & $11-12$ & Soil & Environmental & $x$ & $x$ & $x$ & $x$ & -- \\
\hline $\mathrm{C08}$ & $516 \mathrm{C} 011$ & $8-9$ & Soil & Environmental & $\bar{x}$ & $\mathrm{X}$ & $\mathrm{x}$ & $\mathrm{X}$ & $\overline{--}$ \\
\hline D02 & $516 \mathrm{D} 002^{\mathrm{a}}$ & Interior of Pipe & Sediment & Waste Characterization & $x$ & $x$ & $x$ & $x$ & $\mathrm{x}$ \\
\hline D03 & $516 \mathrm{D} 003^{\mathrm{a}}$ & $4-5$ & Soil & Environmental & $x$ & $\mathrm{x}$ & $x$ & $x$ & $x$ \\
\hline D04 & $516 \mathrm{D} 004^{\mathrm{a}}$ & $4-5$ & Soil & Environmental & $\mathrm{x}$ & $x$ & $x$ & $x$ & $x$ \\
\hline $\mathrm{N} / \mathrm{A}$ & $516 C 303$ & NA & Water & Field Blank & -- & -- & $\overline{--}$ & -- & $\mathrm{X}$ \\
\hline $\bar{N} / \mathrm{A}$ & $516 C 304$ & NA & Water & Trip Blank & $\mathrm{X}$ & -- & -- & -- & -- \\
\hline
\end{tabular}

aSample was collected from the interior of the pipe that is part of CAS 06-51-01. Sample was incorrectly numbered using the designator "d" for CAS 06-59-03. The sample number will remain unchanged.

NA $=$ Not applicable

-- = Not analyzed 


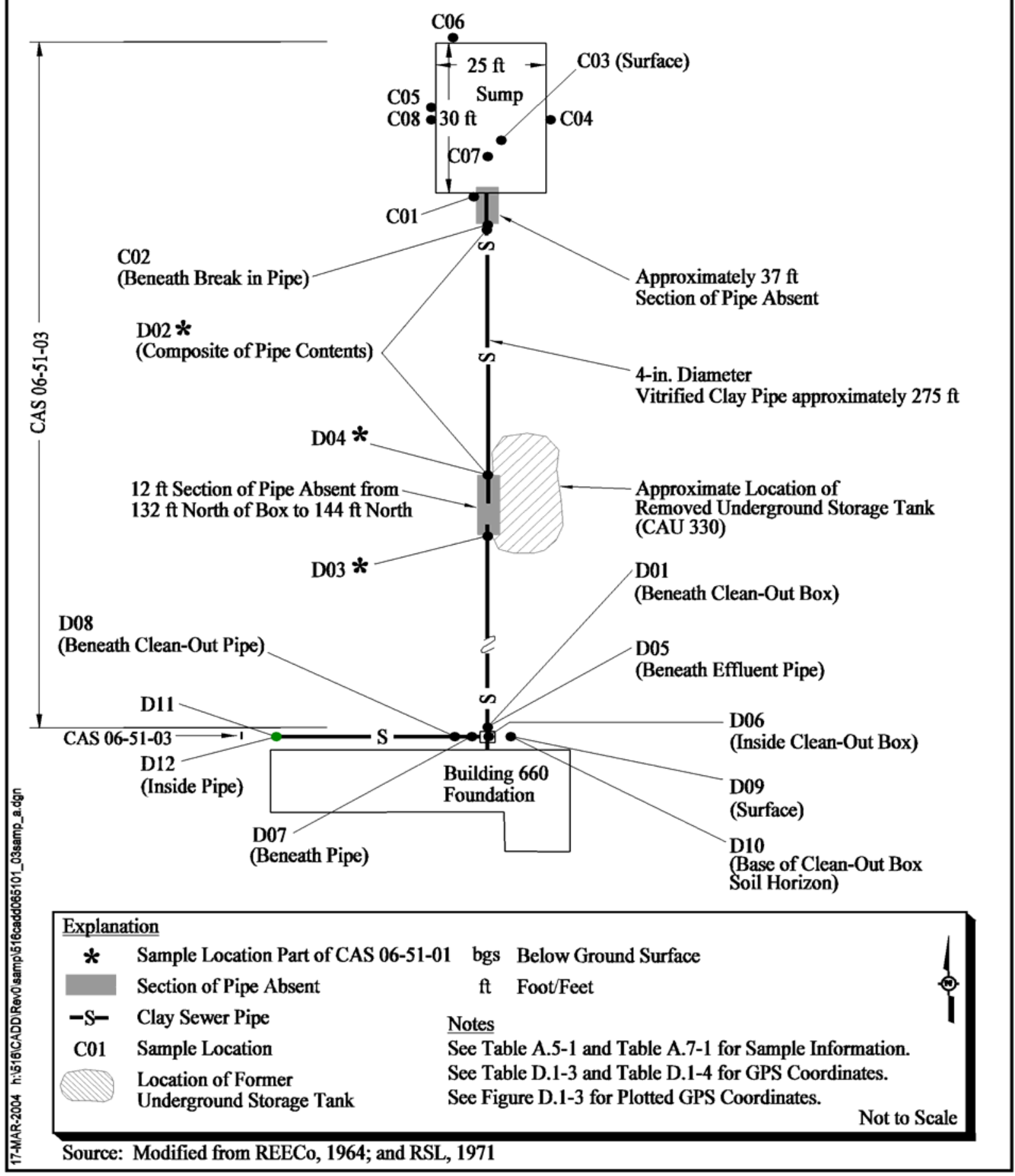

Figure A.5-1

CAU 516, CAS 06-51-01, Sump and Piping, and CAS 06-51-03, Clean Out Box and Piping, Sample Locations 
established at $20 \mathrm{ppm}$. The TPH FSL was established at $75 \mathrm{ppm}$. The FSLs less than $75 \mathrm{ppm}$ are considered to be less than the action level of $100 \mathrm{ppm}$ (NAC, 2003). The VOC FSL was exceeded for five samples (516C003, 516C004, 516C005, 516D002, and 516D003) collected from five locations (C02, C03, C04, D02, and D03) located along the piping between Building 660 and the sump. Analytical results did not show the presence of VOCs.

The radiological FSL for alpha radiation was established daily and ranged between 49 and $128.5 \mathrm{dpm} / 100 \mathrm{~cm}^{2}$. The beta/gamma FSL was established daily and ranged between 1,707 and $1,908 \mathrm{dpm} / 100 \mathrm{~cm}^{2}$. Radiological FSLs were not exceeded for samples collected at CAS 06-51-01.

\section{A.5.2.2 Intrusive Investigation Activities}

Phase I sampling activities included the collection of subsurface soil samples inside and under the piping and just outside the sump at a level equal to the bottom of the sump as outlined in the CAIP (NNSA/NSO, 2003).

Piping from the clean-out box (CAS 06-51-03) leading towards the sump was video mole surveyed to determine whether there are any breaks in the piping. Where there were breaks, samples were collected beneath the pipe (locations C02, D03, and D04). Two sections of pipe were missing with a total of three breaks in the pipe. Approximately $12 \mathrm{ft}$ of pipe is absent midway between the clean-out box and the sump and about $37 \mathrm{ft}$ of the last section of pipe is also missing immediately before the sump (Figure A.5-1). In addition, a composite sample (516D002) was collected of the soil sediment in an 82-ft section of pipe. This sample is identified as location D02 on Figure A.5-1.

Samples were also collected just outside the four edges of the sump and three samples were collected from the middle of the sump at various depths. Six samples were collected from the sump and submitted for laboratory analysis.

\section{A.5.2.3 Waste Characterization}

Waste characterization activities conducted at CAS 06-51-01 included a visual assessment. 


\section{A.5.2.3.1 Visual Assessment}

Corrective Action Site 06-51-01 includes about $275 \mathrm{ft}$ of piping from the clean-out box to the sump and the sump. The sump appears to have been filled with soil. Based on field observations, the dimensions of the sump are estimated to be $25 \mathrm{ft}$ wide by $30 \mathrm{ft}$ long by $10 \mathrm{ft}$ deep (Figure A.5-1). A video mole survey of the piping was conducted (except for the missing sections). There were no breaks in the piping other than the breaks from the missing sections. The piping was dry and had some residual material at the northernmost section of piping. A composite sample (D02) was collected from residual material from each end of the section of pipe. The piping is all 4-in. VCP and did not appear to be stained or corroded.

An engineering drawing showed the sump to be $40 \mathrm{ft}$ wide and $50 \mathrm{ft}$ long and $8 \mathrm{ft}$ deep (REECo, 1964). The engineering drawings call for three-strand, barbwire fence with "T" posts. When excavating both the east and west edges of the sump with the backhoe, barbwire, and " $T$ " posts were uncovered near the surface of the excavations. There was a slight change in the color and texture of the soil between the sump and native soil outside the sump. The interface between the sump base and the native soil is estimated to be $10 \mathrm{ft}$ bgs. No obvious release of contaminants were observed during the visual inspection.

\section{A.5.2.4 Sample Analysis}

Investigation samples were analyzed for VOCs, SVOCs, RCRA metals, beryllium, TPH (DRO/GRO), PCBs, isotopic $\mathrm{Pu}, \mathrm{Sr}-90$, and gamma-emitting radionuclides. The analytical parameters and laboratory methods used to analyze the investigation samples are listed in Table A.2-2. Table A.5-1 lists the specific analytical suite for CAS 06-51-01.

\section{A.5.3 Analytical Results Equal to or Greater than Minimum Reporting Limits}

Analytical results for the soil samples with concentrations equal to or greater than the MRLs or MDCs (NNSA/NSO, 2003) are summarized in the following sections. These results were then compared to the PALs identified in the CAIP. The radiological results were compared to the PALs listed in ROTC No. 1 of the CAIP. Results greater than PALs or regulatory disposal limits are identified by bold text in the analytical tables. The complete data set is maintained in the project file as hard copy and in electronic format. 


\section{A.5.3.1 Total Volatile Organic Compound Analytical Results for Soil Samples}

Total VOC concentrations for soil samples were not equal or greater than the MRLs.

\section{A.5.3.2 Total Semivolatile Organic Compound Analytical Results for Soil Samples}

Total SVOC analytical results for soil samples equal to or greater than the MRLs are reported in Table A.5-2. The concentrations of the reported SVOCs were less than the PALs.

Table A.5-2

Soil Sample Results for Total SVOCs Equal to or Greater than Minimum Reporting Limits at CAS 06-51-01

\begin{tabular}{|c|c|c|c|c|c|}
\hline \multirow{2}{*}{$\begin{array}{c}\text { Sample } \\
\text { Location }\end{array}$} & $\begin{array}{c}\text { Sample } \\
\text { Number }\end{array}$ & \multirow{2}{*}{$\begin{array}{c}\text { Depth } \\
\text { (ft bgs) }\end{array}$} & \multicolumn{3}{c|}{ Contaminants of Potential Concern $(\mu \mathrm{g} / \mathrm{kg})$} \\
\cline { 4 - 6 } & & 2,4-Dimethylphenol & 4-Methylphenol & Bis(2-Ethylhexyl)Phthalate \\
\hline \multicolumn{2}{|c|}{ Preliminary Action Levels } & $12,000,000$ & $3,100,000$ & 120,000 \\
\hline $\mathrm{D} 02$ & $516 \mathrm{D} 002^{\mathrm{b}}$ & Interior of Pipe & 660 & 1,700 & 1,400 \\
\hline
\end{tabular}

aU.S. Environmental Protection Agency, Region 9 Preliminary Remediation Goals (PRGs) (EPA, 2002)

${ }^{b}$ This sample was incorrectly numbered using the designator "d" for CAS 06-59-03. The sample number will remain unchanged.

$\mathrm{ft}$ bgs $=$ Feet below ground surface

$\mu \mathrm{g} / \mathrm{kg}=$ Micrograms per kilogram

\section{A.5.3.3 Total RCRA Metal Analytical Results for Soil Samples}

The RCRA metal concentrations including beryllium equal to or greater than the MRLs are reported in Table A.5-3. The concentrations of all the metals including beryllium were less that the PALs.

\section{A.5.3.4 Total Petroleum Hydrocarbon Analytical Results for Soil Samples}

Total petroleum hydrocarbon-DRO analytical results for soil samples equal to or greater than the MRLs are reported in Table A.5-4. The TPH-DRO concentration for sample 516D002 (contents of the 82 -ft pipe segment) (220 mg/kg) exceeded the action level of $100 \mathrm{ppm}$ (NAC, 2003).

\section{A.5.3.5 Polychlorinated Biphenyl Analytical Results for Soil Samples}

The PCB analytical results for soil samples were less than the MRLs. 
Table A.5-3

Soil Sample Results for Total Metals Equal to or Greater than Minimum Reporting Limits at CAS 06-51-01

\begin{tabular}{|c|c|c|c|c|c|c|c|c|c|c|c|}
\hline \multirow{2}{*}{$\begin{array}{l}\text { Sample } \\
\text { Location }\end{array}$} & \multirow{2}{*}{$\begin{array}{l}\text { Sample } \\
\text { Number }\end{array}$} & \multirow{2}{*}{$\begin{array}{c}\text { Depth } \\
\text { (ft bgs) }\end{array}$} & \multicolumn{9}{|c|}{ Contaminants of Potential Concern (mg/kg) } \\
\hline & & & Aluminum & Arsenic & Barium & Beryllium & Cadmium & Chromium & Lead & Selenium & Mercury \\
\hline \multicolumn{3}{|c|}{ Preliminary Action Levels } & $100,000^{a}$ & $23^{b}$ & $67,000^{\mathrm{a}}$ & $1,900^{\mathrm{a}}$ & $450^{\mathrm{a}}$ & $450^{\mathrm{a}}$ & $750^{\mathrm{a}}$ & $5,100^{\mathrm{a}}$ & 310 \\
\hline \multirow{2}{*}{$\mathrm{C} 01$} & $516 \mathrm{C} 001$ & $8.0-10.0$ & -- & 5 & 240 & 0.74 & 0.79 & 7.1 & 15 & 0.62 & -- \\
\hline & $516 \mathrm{C002}$ & $8.0-10.0$ & -- & 4.8 & 240 & 0.7 & 0.8 & 6.6 & 12 & 0.54 & -- \\
\hline \multirow{2}{*}{$\mathrm{C} 02$} & $516 \mathrm{C} 003$ & $8.0-10.0$ & -- & 6 & 170 & 0.75 & -- & 6.8 & 11 & 0.82 & -- \\
\hline & $516 \mathrm{C008}$ & $10.0-11.0$ & 8,200 & 5.4 & 210 & 0.75 & -- & 7.4 & 9.4 & 0.9 & -- \\
\hline $\mathrm{C03}$ & $516 \mathrm{C004}$ & $0.0-0.5$ & -- & 4.6 & 250 & 0.66 & -- & 5.4 & 11 & 0.52 & -- \\
\hline $\mathrm{CO4}$ & $516 C 005$ & $9.0-10.0$ & -- & 5.7 & 220 & 0.85 & -- & 7.6 & 9.7 & 1.2 & -- \\
\hline $\mathrm{C06}$ & $516 \mathrm{C} 012$ & $7.0-8.0$ & 8,800 & 5.5 & 230 & 0.79 & -- & 7.8 & 9.5 & 0.7 & -- \\
\hline \multirow{2}{*}{$\mathrm{C} 07$} & $516 C 009$ & $8.5-9.5$ & 8,700 & 4.5 & 280 & 0.78 & -- & 7.9 & 11 & 0.55 & -- \\
\hline & $516 \mathrm{C} 010$ & $11.0-12.0$ & 10,000 & 6 & 230 & 0.91 & -- & 7.8 & 9.8 & -- & -- \\
\hline $\mathrm{C08}$ & $516 C 011$ & $8.0-9.0$ & 10,000 & 5.8 & 400 & 0.89 & -- & 7.4 & 9.9 & 0.75 & -- \\
\hline D02 & $516 \mathrm{D} 002^{\mathrm{c}}$ & $\begin{array}{l}\text { Interior of } \\
\text { Pipe }\end{array}$ & -- & 5.2 & 300 & 0.68 & 14 & 15 & 68 & 0.74 & 3.9 \\
\hline D03 & $516 \mathrm{D} 003^{\mathrm{c}}$ & $4.0-5.0$ & - & 5.9 & 190 & 0.8 & -- & 7 & 14 & 0.64 & -- \\
\hline D04 & $516 \mathrm{D} 004^{\mathrm{C}}$ & $4.0-5.0$ & -- & 6.7 & 180 & 0.86 & -- & 7.6 & 9.3 & 0.88 & -- \\
\hline
\end{tabular}

aU.S. Environmental Protection Agency, Region 9 Preliminary Remediation Goals (PRGs) (EPA, 2002)

bBased on the background concentrations for metals. Background is considered the mean plus two times the standard deviation for sediment samples collected by the Nevada Bureau of Mines and Geology throughout the Nevada Test and Training Range (NBMG, 1998; Moore, 1999).

"Sample was incorrectly numbered using the designator "d" for CAS 06-59-03. The sample number will remain unchanged.

$\mathrm{ft}$ bgs $=$ Feet below ground surface

$\mathrm{mg} / \mathrm{kg}=$ Milligrams per kilogram

-- = Not detected at concentrations equal to or greater than minimum reporting limits 
Table A.5-4

\section{Soil Sample Results for TPH-DRO Equal to or Greater than Minimum Reporting Limits at CAS 06-51-01}

\begin{tabular}{|c|c|c|c|}
\hline \multirow{2}{*}{$\begin{array}{l}\text { Sample } \\
\text { Location }\end{array}$} & \multirow{2}{*}{$\begin{array}{l}\text { Sample } \\
\text { Number }\end{array}$} & \multirow{2}{*}{$\begin{array}{l}\text { Depth } \\
\text { (ft bgs) }\end{array}$} & Contaminants of Potential Concern (mg/kg) \\
\hline & & & Diesel-Range Organics \\
\hline \multicolumn{3}{|c|}{ Preliminary Action Levels ${ }^{a}$} & 100 \\
\hline \multirow{2}{*}{ C01 } & $516 \mathrm{C} 001$ & $8.0-10.0$ & $27(\mathrm{H})$ \\
\hline & $516 \mathrm{C} 002$ & $8.0-10.0$ & $31(\mathrm{~J})$ \\
\hline D02 & $516 \mathrm{D} 002^{\mathrm{b}}$ & Interior of pipe & $220(\mathrm{H})$ \\
\hline
\end{tabular}

aNevada Administrative Code, "Water Controls" (NAC, 2003)

${ }^{b}$ This sample was incorrectly numbered using the designator "d" for CAS 06-59-03. The sample number will remain unchanged.

$\mathrm{ft}$ bgs = Feet below ground surface

$\mathrm{mg} / \mathrm{kg}=$ Milligrams per kilogram

$\mathrm{H}=$ The fuel pattern was in the heavier end of the retention time window for the analyte of interest.

$\mathrm{J}=$ Estimated value. Qualifier added to laboratory data; record accepted. Surrogate recovery exceeded the upper limits.

\section{A.5.3.6 Gamma Spectroscopy Analytical Results for Soil Samples}

Gamma spectroscopy concentrations for soil samples equal to or greater than MDCs are listed in Table A.5-5. None of the gamma spectroscopy concentration were equal to or greater than the PALs.

\section{A.5.3.7 Isotopic Plutonium Analytical Results for Soil Samples}

Isotopic plutonium analytical results for soil samples equal to or greater than the MDCs are reported in Table A.5-6. None of the isotopic plutonium concentrations were equal to or greater than the PALs.

\section{A.5.3.8 Strontium-90 Analytical Results for Soil Samples}

Strontium-90 concentrations for soil samples were less than the MDCs. 
Table A.5-5

Soil Sample Results for Gamma-Emitting Radionuclides Equal to or Greater than Minimum Detectable Concentrations at CAS 06-51-01

\begin{tabular}{|c|c|c|c|c|c|c|c|c|}
\hline \multirow{2}{*}{$\begin{array}{l}\text { Sample } \\
\text { Location }\end{array}$} & \multirow{2}{*}{$\begin{array}{l}\text { Sample } \\
\text { Number }\end{array}$} & \multirow{2}{*}{$\begin{array}{l}\text { Depth } \\
\text { (ft bgs) }\end{array}$} & \multicolumn{6}{|c|}{ Contaminants of Potential Concern $(\mathrm{pCi} / \mathrm{g})$} \\
\hline & & & \multicolumn{2}{|c|}{ Actinium-228 } & Bismuth-214 & Lead-212 & Lead-214 & Thallium-208 \\
\hline \multicolumn{3}{|c|}{ Preliminary Action Levels ${ }^{a}$} & 5 & 15 & 15 & 15 & 15 & 15 \\
\hline \multirow{2}{*}{$\mathrm{C} 01$} & $516 \mathrm{C} 001$ & $8.0-10.0$ & -- & $1.33 \pm 0.38$ & $1 \pm 0.28$ & $1.63 \pm 0.34$ & $0.97 \pm 0.24$ & $0.52 \pm 0.15$ \\
\hline & $516 \mathrm{C} 002$ & $8.0-10.0$ & -- & $1.09 \pm 0.31$ & $1.16 \pm 0.28$ & $1.78 \pm 0.35$ & $1.23 \pm 0.26$ & $0.59 \pm 0.15$ \\
\hline $\mathrm{C} 02$ & $516 \mathrm{C} 003$ & $8.0-10.0$ & -- & $1.49 \pm 0.42$ & $0.78 \pm 0.25$ & $1.79 \pm 0.37$ & $1.08 \pm 0.25$ & $0.53 \pm 0.15$ \\
\hline $\mathrm{C03}$ & $516 \mathrm{C} 004$ & $0.0-0.5$ & $1.46 \pm 0.41$ & -- & $0.91 \pm 0.27$ & $1.58 \pm 0.34$ & $1.13 \pm 0.27$ & $0.58 \pm 0.16$ \\
\hline $\mathrm{CO4}$ & $516 \mathrm{C} 005$ & $9.0-10.0$ & -- & $1.48 \pm 0.38$ & $1.13 \pm 0.28$ & $1.71 \pm 0.34$ & $1.09 \pm 0.24$ & $0.49 \pm 0.13$ \\
\hline $\mathrm{C} 05$ & $516 \mathrm{C} 006$ & $9.0-10.0$ & -- & $1.73 \pm 0.43$ & $1.27 \pm 0.3$ & $1.95 \pm 0.39$ & $1.25 \pm 0.28$ & $0.68 \pm 0.17$ \\
\hline C06 & $516 \mathrm{C} 007$ & $6.0-7.0$ & -- & $1.5 \pm 0.42$ & $0.94 \pm 0.27$ & $1.55 \pm 0.33$ & $1.02 \pm 0.24$ & $0.47 \pm 0.14$ \\
\hline D02 & $516 \mathrm{D} 002^{\mathrm{b}}$ & $\begin{array}{l}\text { Interior of } \\
\text { pipe }\end{array}$ & -- & $1.58 \pm 0.39$ & $0.92 \pm 0.25$ & $1.61 \pm 0.32$ & $1.13 \pm 0.25$ & $0.48 \pm 0.13$ \\
\hline D03 & $516 \mathrm{D} 003^{\mathrm{b}}$ & $4.0-5.0$ & -- & $1.45 \pm 0.44$ & $1.07 \pm 0.29$ & $1.64 \pm 0.36$ & $1.06 \pm 0.26$ & $0.44 \pm 0.14$ \\
\hline D04 & $516 \mathrm{D} 004^{\mathrm{b}}$ & $4.0-5.0$ & -- & $1.57 \pm 0.39$ & $1 \pm 0.27$ & $1.82 \pm 0.36$ & $1.11 \pm 0.25$ & $0.63 \pm 0.16$ \\
\hline
\end{tabular}

a'Taken from the generic guidelines for residual concentrations of Radium-226, Radium-228, Thorium-230, and Thorium-232 as found in Chapter IV of DOE Order 5400.5, Change 2, "Radiation Protection of the Public and Environment." The PAL for these isotopes is specified as $5 \mathrm{pCi} / \mathrm{g}$ averaged over the first 15 centimeters of soil and $15 \mathrm{pCi} / \mathrm{g}$ for deeper soils. For purposes of this document, 15 centimeters is equivalent to $0.5 \mathrm{ft}$ (6 in.) (DOE, 1993).

bSample was incorrectly numbered using the designator "d" for CAS 06-59-03. The sample number will remain unchanged.

$\mathrm{ft}$ bgs $=$ Feet below ground surface

$\mathrm{pCi} / \mathrm{g}=$ Picocuries per gram

$--=$ Not analyzed

\section{A.5.4 Contaminants of Concern}

The TPH-DRO concentration $(220 \mathrm{mg} / \mathrm{kg}$ ) detected in soil sample 516D002, composited from soil collected from both ends of the 82-ft pipe segment (D02), exceeded the action level of $100 \mathrm{ppm}$ for TPH (NAC, 2003).

\section{A.5.5 Nature and Extent of Contamination}

The TPH-DRO contamination was found in sample 516D002 at concentrations greater than the action level. Soil samples collected from below the pipe at the same locations where there were breaks in 
Table A.5-6

\section{Soil Sample Results for Isotopic Plutonium Detected Equal to or Greater than Minimum Detectable Concentrations at CAS 06-51-01}

\begin{tabular}{|c|c|c|c|c|}
\hline \multirow{2}{*}{$\begin{array}{c}\text { Sample } \\
\text { Location }\end{array}$} & \multirow{2}{*}{$\begin{array}{c}\text { Sample } \\
\text { Number }\end{array}$} & \multirow{2}{*}{$\begin{array}{l}\text { Depth } \\
\text { (ft bgs) }\end{array}$} & \multicolumn{2}{|c|}{ Contaminants of Potential Concern $(\mathrm{pCi} / \mathrm{g})$} \\
\hline & & & Plutonium-238 & Plutonium-239 \\
\hline \multicolumn{3}{|c|}{ Preliminary Action Levels ${ }^{a}$} & 7.78 & 7.62 \\
\hline $\mathrm{C03}$ & $516 \mathrm{C} 004$ & $0.0-0.5$ & --- & $0.066 \pm 0.03$ \\
\hline D02 & $516 \mathrm{D} 002^{\mathrm{b}}$ & Interior of Pipe & $0.05 \pm 0.025(\mathrm{LT})$ & $0.162 \pm 0.049$ \\
\hline
\end{tabular}

${ }^{a}$ Taken from the Construction, Commercial, Industrial land use scenario in Table 2.1 of the NCRP Report No. 129, Recommended Screening Limits for Contaminated Surface Soil and Review Factors Relevant to Site-Specific Studies (NCRP, 1999). The values provided in this source document were scaled to a 15-mrem per year dose.

bSample was incorrectly numbered using the designator "d" for CAS 06-59-03. The sample number will remain unchanged.

$\mathrm{ft}$ bgs $=$ Feet below ground surface $\mathrm{pCi} / \mathrm{g}=$ Picocuries per gram

$\mathrm{LT}=$ Result is less than requested minimum detectable concentration, greater than specific minimum detectable concentration

the pipe were not contaminated. The results show that the contamination is contained within the pipe. The volume of soil in the pipe is approximately $1 \mathrm{yd}^{3}$.

\section{A.5.6 Revised Conceptual Site Model}

No variations in the conceptual site model were identified. 


\section{A.6.0 CAS 06-51-02, Clay Pipe and Debris}

Corrective Action Site 06-51-02, Clay Pipe and Debris, is a housekeeping CAS. Sampling activities were not required for this CAS. The CAS consisted of a clay pipe, some concrete debris, some metal conduit, and some wood debris (Figure A.6-1). All the debris and pipe was screened for radioisotopes, removed from the site, and disposed of in the 10c Landfill. 


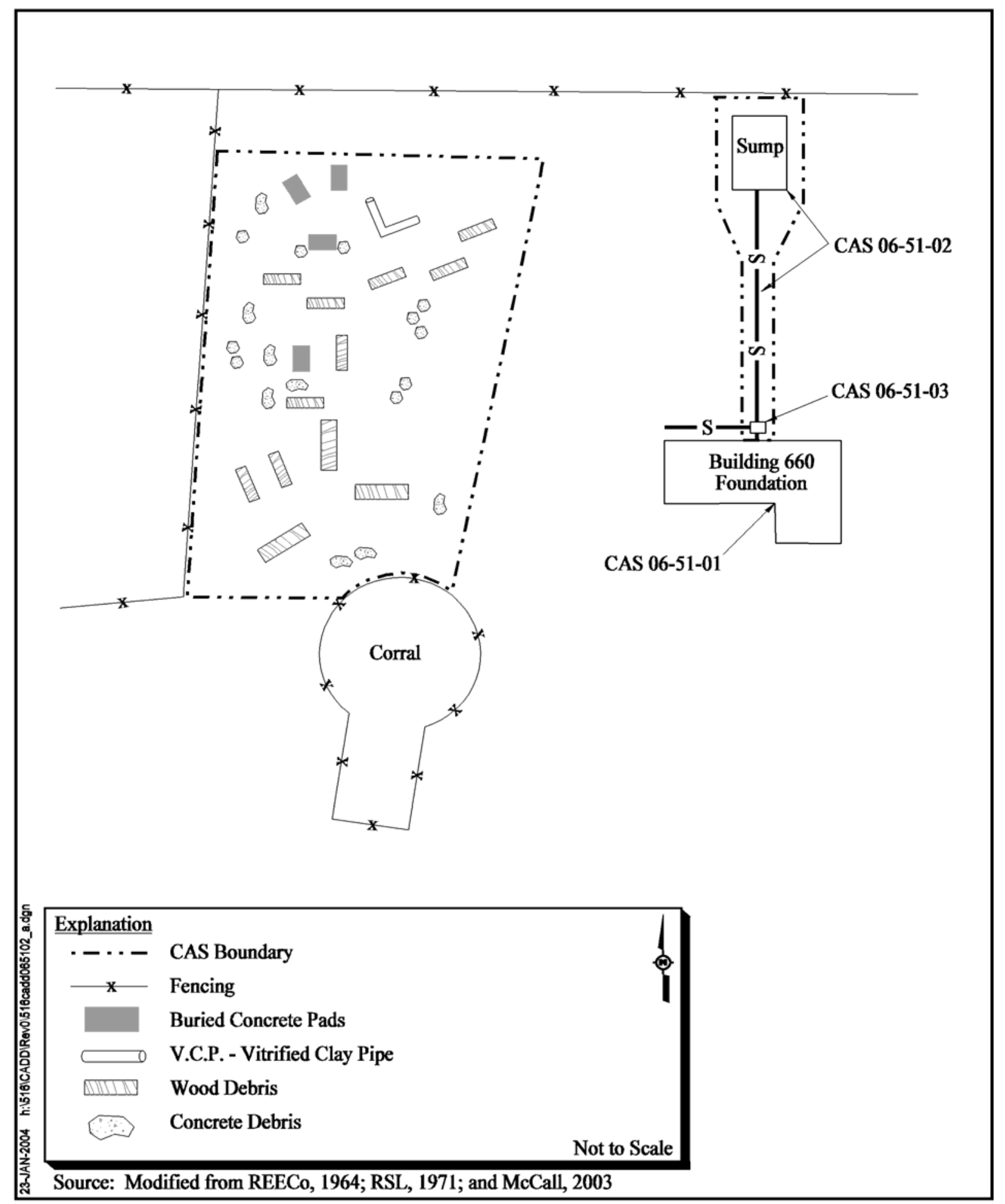

Figure A.6-1

CAU 516, CAS 06-51-02, Clay Pipe and Debris, Site of Debris Removal 


\section{A.7.0 CAS 06-51-03, Clean Out Box and Piping}

Corrective Action Site 06-51-03 is part of the septic system associated with Building 660, which was used for the Animal Investigation Program conducted by the U.S. Public Health Service. The CAS initially consisted of the clean-out box. During the CAI, a 4-in. VCP was discovered running west from the box along the foundation of the building and was included in the CAS. The purpose of this piping in not known. The clean-out box is located only a few feet away from the north side of the building foundation. The wastewater from the drains in Building 660 flowed through the clean-out box and traveled north through $275 \mathrm{ft}$ of pipe to the sump (CAS 05-51-01). Additional detail for this CAS is provided in the CAIP (NNSA/NSO, 2003).

\section{A.7.1 Corrective Action Investigation}

Nine environmental soil samples (including one duplicate) from 8 locations (D01, D05, D07, D08, D09, D10, D11, and D12); 9 waste characterization samples from 6 locations (D6 through D12); 4 water; and $1 \mathrm{MS} / \mathrm{MSD}$ soil sample for QC purposes were collected during the investigation of CAS 06-51-03. Nine samples were collected for waste management purposes. The samples were analyzed for the parameters listed in Table A.7-1. The sample locations are shown in Figure A.5-1.

\section{A.7.1.1 Deviations}

There were no deviations from the investigation activities specified in the CAIP for CAS 06-51-03.

\section{A.7.2 Investigation Activities}

The following sections provide descriptions of the CAS-specific activities conducted to complete the investigation as outlined in the CAIP and listed in Table A.2-1.

\section{A.7.2.1 Field Screening}

Soil samples were screened for VOCs, TPH, and alpha and beta/gamma radiation. The FSRs were compared to FSLs to guide subsequent sampling and analytical decisions. The VOC FSL was established at $20 \mathrm{ppm}$. The TPH FSL was established at $75 \mathrm{ppm}$. The FSLs less than $75 \mathrm{ppm}$ are considered to be below the action level of 100 ppm (NAC, 2003). 
Table A.7-1

Samples Collected at CAS 06-51-03

\begin{tabular}{|c|c|c|c|c|c|c|c|c|c|c|c|c|c|c|}
\hline $\begin{array}{l}\text { Sample } \\
\text { Location }\end{array}$ & $\begin{array}{l}\text { Sample } \\
\text { Number }\end{array}$ & $\begin{array}{l}\text { Depth } \\
\text { (ft bgs) }\end{array}$ & $\begin{array}{l}\text { Sample } \\
\text { Matrix }\end{array}$ & Purpose & $\begin{array}{l}\text { O } \\
\frac{\pi}{0} \\
\frac{\pi}{0}\end{array}$ & $\begin{array}{l}0 \\
\frac{0}{3} \\
\frac{\pi}{0} \\
\frac{\pi}{0}\end{array}$ & 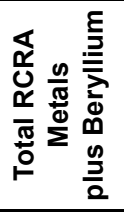 & 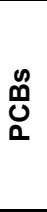 & $\begin{array}{l}\text { O } \\
\frac{1}{0} \\
\stackrel{1}{1} \\
\frac{1}{0} \\
\stackrel{F}{F}\end{array}$ & $\begin{array}{l}\text { o } \\
\stackrel{r}{a} \\
\underline{1} \\
\text { İ } \\
\text { F }\end{array}$ & $\begin{array}{l}\frac{\pi}{0} \\
\frac{0}{0} \\
\frac{0}{0} \\
0 \\
0 \\
0 \\
0\end{array}$ & 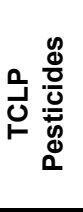 & 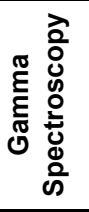 & 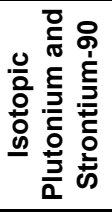 \\
\hline D01 & 516D001 & $2-3$ & Soil & Environmental & $\mathrm{X}$ & $\bar{X}$ & $\mathrm{X}$ & $\bar{X}$ & $\bar{X}$ & $\bar{x}$ & $\overline{--}$ & -- & $\bar{x}$ & $\bar{X}$ \\
\hline \multirow{2}{*}{ D05 } & 516D005 & $2-3$ & Soil & Environmental & -- & -- & -- & -- & -- & -- & -- & -- & $\mathrm{x}$ & $\mathrm{x}$ \\
\hline & 516D007 & $2-3$ & Soil & Environmental & $\mathrm{x}$ & $\bar{x}$ & $\bar{x}$ & $\bar{x}$ & $\bar{x}$ & $\bar{x}$ & -- & -- & -- & -- \\
\hline D07 & 516D009 & $1.6-1.8$ & Soil & Environmental & -- & -- & -- & $x$ & -- & $\bar{x}$ & $\mathrm{x}$ & -- & -- & -- \\
\hline D08 & $516 \mathrm{D} 010$ & $1.0-1.5$ & Soil & Environmental & -- & -- & -- & $\mathrm{X}$ & -- & $\mathrm{x}$ & $\bar{x}$ & -- & -- & -- \\
\hline D09 & 516D012 & $0-1$ & Soil & Duplicate of 516D011 & -- & -- & -- & $\mathrm{x}$ & -- & $\mathrm{x}$ & $x$ & -- & -- & -- \\
\hline D10 & $516 \mathrm{D} 013$ & $2.4-2.7$ & Soil & Environmental & -- & -- & -- & $\bar{x}$ & -- & $\bar{x}$ & $\bar{x}$ & -- & -- & -- \\
\hline D11 & 516D014 & $0-1$ & Soil & Environmental & -- & -- & -- & $\mathrm{x}$ & -- & $\mathrm{x}$ & $x$ & -- & -- & -- \\
\hline D12 & 516D015 & $\begin{array}{l}\text { Inside of Pipe Connect to } \\
\text { West Side of Clean-Out Box }\end{array}$ & Soil & Environmental & -- & -- & -- & $x$ & -- & $x$ & $x$ & - & -- & -- \\
\hline \multirow{3}{*}{ D06 } & $516 \mathrm{D} 006$ & $\begin{array}{c}\text { Interior of } \\
\text { Clean-Out Box }\end{array}$ & Soil & Waste Characterization & -- & -- & -- & -- & -- & -- & -- & -- & $x$ & $x$ \\
\hline & $516 \mathrm{D} 008$ & $\begin{array}{c}\text { Interior of } \\
\text { Clean-Out Box }\end{array}$ & Soil & Waste Characterization & $x$ & $x$ & $x$ & $x$ & $x$ & $x$ & -- & -- & -- & -- \\
\hline & 516D501 & $\begin{array}{c}\text { Interior of } \\
\text { Clean-Out Box }\end{array}$ & Soil & Waste Characterization & -- & -- & - & -- & -- & -- & -- & $x$ & -- & -- \\
\hline D07 & 516D502 & $1-1.2$ & Soil & Waste Characterization & -- & -- & -- & -- & -- & -- & -- & $\bar{x}$ & -- & -- \\
\hline D08 & 516D503 & $1.5-1.8$ & Soil & Waste Characterization & -- & -- & -- & -- & -- & -- & -- & $\mathrm{x}$ & -- & -- \\
\hline \multirow{2}{*}{ D09 } & 516D504 & $0-0.5$ & Soil & Waste Characterization & -- & -- & -- & -- & -- & -- & -- & $\bar{x}$ & -- & -- \\
\hline & 516D011 & $0-1$ & Soil & $\mathrm{MS} / \mathrm{MSD}$ & -- & -- & -- & $\bar{x}$ & -- & $\bar{x}$ & $\mathrm{X}$ & - & -- & -- \\
\hline D10 & $516 \mathrm{D} 505$ & $2-2.5$ & Soil & Waste Characterization & -- & -- & -- & -- & -- & -- & -- & $\mathrm{x}$ & -- & -- \\
\hline D11 & 516D506 & $0-0.5$ & Soil & Waste Characterization & -- & - & -- & -- & -- & -- & -- & $x$ & -- & -- \\
\hline D12 & $516 \mathrm{D} 507$ & $\begin{array}{l}\text { Inside of Pipe Connect to } \\
\text { West Side of Clean-Out Box }\end{array}$ & Soil & Waste Characterization & -- & -- & -- & -- & -- & -- & -- & $x$ & -- & -- \\
\hline \multirow{4}{*}{ NA } & 516D301 & $\mathrm{NA}$ & Water & Trip Blank & $x$ & -- & -- & -- & -- & -- & -- & -- & -- & -- \\
\hline & 516D302 & NA & Water & Trip Blank & $x$ & -- & -- & -- & -- & -- & -- & -- & -- & -- \\
\hline & 516D306 & NA & Water & Field Blank & -- & -- & -- & $\mathrm{x}$ & -- & $x$ & -- & -- & -- & -- \\
\hline & 516D307 & NA & Water & Source blank & -- & -- & -- & $x$ & -- & $x$ & -- & -- & -- & -- \\
\hline
\end{tabular}

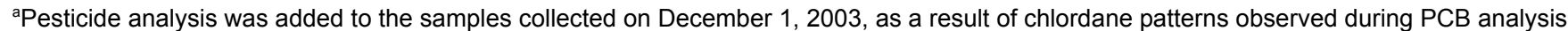

$\mathrm{NA}=$ Not applicable

$--=$ Not analyzed 
The radiological FSLs for alpha radiation were established daily and ranged between 49 and $128.5 \mathrm{dpm} / 100 \mathrm{~cm}^{2}$. The beta/gamma FSLs were established daily and ranged between 1,253 and $1,908 \mathrm{dpm} / 100 \mathrm{~cm}^{2}$.

The VOC and alpha and beta/gamma radiation FSLs were not exceeded during sampling activities; however, the TPH FSL was exceeded for sample 516D006 $(110 \mathrm{mg} / \mathrm{kg}$ ) at location D06 (clean-out box).

\section{A.7.2.2 Intrusive Investigation Activities}

This section discusses the intrusive sampling effort that was conducted at CAS 06-51-03.

\section{A.7.2.2.1 Initial Sampling}

Initial sampling activities included the collection of three soil samples from below the effluent pipe of the clean-out box and from the soil horizon beneath the clean-out box as outlined in the CAIP (NNSA/NSO, 2003). These subsurface samples were collected using a backhoe. A waste characterization sample was collected from the clean-out box using hand tools. The treatment of the waste characterization samples are discussed in Section A.3.1.

\section{A.7.2.2.2 Step-Out Sampling}

Location D06 was identified from the Phase I sampling activities as a location of concern due to the presence of TPH-DRO (516D006) in the clean-out box contents at a concentration of $180 \mathrm{mg} / \mathrm{kg}$, exceeding the action level of $100 \mathrm{ppm}$ (NAC, 2003). Technical chlordane concentrations less than the MRLs were detected in the clean-out box contents. In order to verify that the technical chlordane concentrations did not exceed action levels, additional waste characterization samples were collected from the clean-out box content (D06), interior of the west trending pipe (D12), surface samples (D09, D11), and beneath the piping (D07, D08, and D10) for TCLP chlordane analysis. All the results for TCLP chlordane were below action levels. 


\section{A.7.2.3 Waste Characterization}

Waste characterization activities conducted at CAS 06-51-03 included visual assessments (e.g., video mole survey), photodocumentation, and collecting waste characterization sampling of the clean-out box contents and associated piping. The following sections discuss the waste characterization activities.

\section{A.7.2.3.1 Visual Assessment}

The clean-out box has the exterior dimensions of 2 by 2 by $2 \mathrm{ft}$. The side walls and bottom of the clean-out box are concrete about $3 \mathrm{in}$. thick and the box has an open top. The top is level with the ground surface. A 4-in. VCP is in the bottom of the box that runs from the building and connects to the piping and sump associated with CAS 06-51-01. The top half of this pipe has been cut open inside the clean-out box. The clean-out box contains about 4 to 6 in. of sediment (approximately $\left.0.5 \mathrm{yd}^{3}\right)$.

Just to the west side of the clean-out box, the pipe becomes "Y" shaped, with one leg of the "Y" continuing to the west while the other leg of the "Y" angles up towards the surface and is fitted with a compression plug. The pipe continues to the west to about the end of the foundation of the building, where it is exposed at the ground surface. This is where the pipe is broken and filled with soil. It could not be determined where or to what feature the pipe was connected. The interior of this pipe was visually inspected with a video mole. The pipe was clean, dry, and unbroken up to the point where it is exposed at the ground surface.

\section{A.7.2.3.2 Waste Characterization Sampling}

Analytical results for PCB analysis of the sample collected from the clean-out box contents indicated the possible presence of pesticides; therefore, the analytical suite was expanded to include pesticides and additional samples were collected on December 1, 2003. Technical chlordane was detected in some of these soil samples; therefore, seven additional samples (516D009, 516D010, 516D011, 516D012, 516D013, 516D014) were collected from locations D07, D08, D09, D10, D11, D12, the on January 9, 2004, and analyzed for TCLP chlordane. 


\section{A.7.2.4 Sample Analysis}

Investigation samples were analyzed for CAIP-specific COPCs including VOCs, SVOCs, RCRA metals, beryllium, TPH (DRO/GRO), PCBs, isotopic Pu, Sr-90, and gamma-emitting radionuclides. As previously discussed, pesticides were added to the analytical suite and additional waste characterization samples were collected for the analysis of TCLP chlordane. The analytical parameters and laboratory methods used during the investigation are listed in Table A.2-2. Table A.7-1 lists the specific analytical suite for CAS 06-51-03.

\section{A.7.3 Analytes Detected Equal to or Greater than Minimum Reporting Limits}

Analytical results from the soil samples with concentrations equal to or greater than the MRLs (NNSA/NSO, 2003) are summarized in the following sections. These results were compared to PALs identified in the CAIP or the ROTC No. 1 to the CAIP. Results greater than PALs are identified by bold text in the analytical tables. The waste characterization results for soil samples are compared to appropriate regulatory levels for disposal. The complete data set is maintained in the project file as hard copy and in electronic format.

\section{A.7.3.1 Total Volatile Organic Compound Analytical Results for Soil Samples}

Total VOC analytical results for soil samples equal to or greater than the MRLs are reported in Table A.7-2. The acetone concentration is less than the PAL.

Table A.7-2

Soil Sample Results for Total VOCs Equal to or Greater than Minimum Reporting Limits at CAS 06-51-03

\begin{tabular}{|c|c|c|c|}
\hline $\begin{array}{c}\text { Sample } \\
\text { Location }\end{array}$ & $\begin{array}{c}\text { Sample } \\
\text { Number }\end{array}$ & $\begin{array}{c}\text { Depth } \\
\text { (ft bgs) }\end{array}$ & Contaminants of Potential Concern ( $\mu$ g/kg) \\
\cline { 2 - 3 } & Preliminary Action Levels & Acetone \\
\hline \hline D06 & $516 \mathrm{D} 008$ & Interior of Clean-Out Box & $6,000,000$ \\
\hline
\end{tabular}

aBased on U.S. Environmental Protection Agency, Region 9 Preliminary Remediation Goals (PRGs) (EPA, 2002)

$\mathrm{ft}$ bgs $=$ Feet below ground surface $\mu \mathrm{g} / \mathrm{kg}=$ Micrograms per kilogram

$\mathrm{J}=$ Estimated value 


\section{A.7.3.2 Total Semivolatile Organic Compound Analytical Results for Soil Samples}

Total SVOC analytical results for soil samples equal to or greater than the MRLs are reported in Table A.7-3. All the SVOCs concentrations are less than the PALs.

Table A.7-3

Soil Sample Results for Total SVOCs

Equal to or Greater than Minimum Reporting Limits at CAS 06-51-03

\begin{tabular}{|c|c|c|c|c|c|}
\hline \multirow{2}{*}{$\begin{array}{c}\text { Sample } \\
\text { Location }\end{array}$} & $\begin{array}{c}\text { Sample } \\
\text { Number }\end{array}$ & \multirow{2}{*}{$\begin{array}{c}\text { Depth } \\
\text { (ft bgs) }\end{array}$} & \multicolumn{2}{c|}{ Contaminants of Potential Concern $(\mu \mathrm{g} / \mathrm{kg})$} \\
\cline { 4 - 6 } & & 2,4-Dimethylphenol & 4-Methylphenol & Bis(2-Ethylhexyl)Phthalate \\
\hline \multicolumn{2}{|c|}{ Preliminary Action Levels ${ }^{\mathrm{a}}$} & $12,000,000$ & $3,100,000$ & 120,000 \\
\hline \hline D06 & $516 \mathrm{D} 008$ & $\begin{array}{c}\text { Interior of } \\
\text { Clean-Out Box }\end{array}$ & -- & -- & $810(\mathrm{~J})$ \\
\hline
\end{tabular}

aU.S. Environmental Protection Agency, Region 9 Preliminary Remediation Goals (PRGs) (EPA, 2002)

$\mathrm{ft}$ bgs $=$ Feet below ground surface

$\mathrm{J}=$ Estimated value. Matrix effects may exist. Internal standard area count outside control limits. $\mu \mathrm{g} / \mathrm{kg}=$ Micrograms per kilogram

-- = Not detected at concentrations equal to or greater than minimum reporting limits

\section{A.7.3.3 Total RCRA Metal Analytical Results for Soil Samples}

Total RCRA metals and total beryllium analytical results equal to or greater than the MRLs are reported in Table A.7-4. The concentration of all the RCRA metals and beryllium were less than the PALs.

\section{A.7.3.4 Total Petroleum Hydrocarbon Analytical Results for Soil Samples}

Total petroleum hydrocarbon analytical results for soil samples equal to or greater than the MRLs are reported in Table A.7-5. Sample 516D008, collected from the interior of the clean-out box (D06), had a TPH-DRO concentration of $180 \mathrm{mg} / \mathrm{kg}$, which exceeds the action level of $100 \mathrm{mg} / \mathrm{kg}$ (NAC, 2003). The amount of soil/sediment in the clean-out box is estimated at approximately $0.5 \mathrm{yd}^{3}$. 
Table A.7-4

Soil Sample Results for Total RCRA Metals, Plus Beryllium Equal to or Greater than Minimum Reporting Limits at CAS 06-51-03

\begin{tabular}{|c|c|c|c|c|c|c|c|c|c|c|c|}
\hline \multirow[b]{2}{*}{$\begin{array}{l}\text { Sample } \\
\text { Location }\end{array}$} & \multirow[b]{2}{*}{$\begin{array}{l}\text { Sample } \\
\text { Number }\end{array}$} & \multirow[b]{2}{*}{$\begin{array}{l}\text { Depth } \\
\text { (ft bgs) }\end{array}$} & \multicolumn{9}{|c|}{ Contaminants of Potential Concern (mg/kg) } \\
\hline & & & 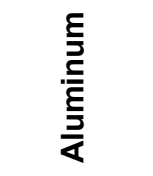 & 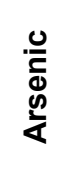 & 竞 & 点 & 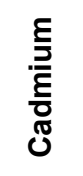 & 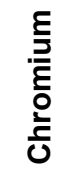 & ర్ల & 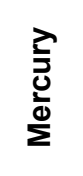 & 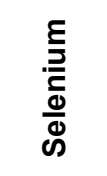 \\
\hline \multicolumn{3}{|c|}{ Preliminary Action Levels } & $100,000^{\mathrm{a}}$ & $23^{b}$ & $67,000^{\mathrm{a}}$ & $1,900^{\mathrm{a}}$ & $450^{a}$ & $450^{a}$ & $750^{\mathrm{a}}$ & $310^{a}$ & $5,100^{\mathrm{a}}$ \\
\hline D01 & $516 \mathrm{D} 001$ & $2.0-3.0$ & -- & 5 & 210 & 0.64 & -- & 5.6 & 10 & -- & 0.72 \\
\hline D05 & $516 \mathrm{D} 007$ & $2.0-3.0$ & -- & 4.8 & 210 & 0.64 & 1.4 & 6.4 & 15 & 0.16 & 0.52 \\
\hline D06 & $516 \mathrm{D} 008$ & $\begin{array}{c}\text { Interior of } \\
\text { Clean-Out Box }\end{array}$ & 5,400 & 4.8 & 300 & -- & 16 & 11 & 61 & 3 & 0.56 \\
\hline
\end{tabular}

U.S. Environmental Protection Agency, Region 9 Preliminary Remediation Goals (PRGs) (EPA, 2002)

'Based on the background concentrations for metals. Background is considered the mean plus two times the standard deviation for sediment samples collected by the Nevada Bureau of Mines and Geology throughout the Nevada Test and Training Range (NBMG, 1998; Moore, 1999).

$\mathrm{ft}$ bgs $=$ Feet below ground surface

$\mathrm{mg} / \mathrm{kg}=$ Milligrams per kilogram

-- = Not detected at concentrations equal to or greater than minimum reporting limits 
Table A.7-5

Soil Sample Results for TPH-DRO

Equal to or Greater than Minimum Reporting Limits at CAS 06-51-03

\begin{tabular}{|c|c|c|c|}
\hline \multirow{2}{*}{$\begin{array}{l}\text { Sample } \\
\text { Location }\end{array}$} & \multirow{2}{*}{$\begin{array}{l}\text { Sample } \\
\text { Number }\end{array}$} & \multirow{2}{*}{$\begin{array}{l}\text { Depth } \\
\text { (ft bgs) }\end{array}$} & $\begin{array}{l}\text { Contaminants of Potential Concern } \\
\qquad(\mathrm{mg} / \mathrm{kg})\end{array}$ \\
\hline & & & Diesel-Range Organics \\
\hline \multicolumn{3}{|c|}{ Preliminary Action Levels ${ }^{a}$} & 100 \\
\hline D05 & 516D007 & $2.0-3.0$ & $6.2(\mathrm{H})$ \\
\hline D06 & 516D008 & Interior of Clean-Out Box & $180(H, Z)$ \\
\hline D08 & $516 \mathrm{D} 010$ & $1.0-1.5$ & $17(\mathrm{H}, \mathrm{Z})$ \\
\hline D11 & 516D014 & $0.0-1.0$ & $15(H, Z)$ \\
\hline D12 & $516 \mathrm{D} 015$ & $\begin{array}{l}\text { (Interior of Pipe Connected to } \\
\text { West Side of Clean-Out Box) }\end{array}$ & $20(H, Z)$ \\
\hline
\end{tabular}

aNevada Administrative Code, "Water Controls" (NAC, 2003)

$\mathrm{ft}$ bgs $=$ Feet below ground surface

$\mathrm{mg} / \mathrm{kg}=$ Milligrams per kilogram

$\mathrm{H}=$ The fuel pattern was in the heavier end of the retention time window for the analyte of interest.

$Z=A$ significant fraction of the reported result did not resemble the patterns of the following petroleum hydrocarbon products: gasoline, JP-4, JP-8, diesel, mineral spirits, motor oil, Stoddard solvent, and Bunker C.

\section{A.7.3.5 Polychlorinated Biphenyl Analytical Results for Soil Samples}

Polychlorinated biphenyl analytical results for soil samples equal to or greater than the MRLs are reported in Table A.7-6. Aroclor 1260, the only reported PCB, concentration is less than the PAL.

\section{A.7.3.6 Pesticide Analytical Results for Soil Samples}

During the PCBs analyses for samples collected at locations D05 and D06, interferences indicating pesticides were identified by the laboratory. As a result, total pesticides analysis was run on samples from locations D05 and D06. The analytical results showed the presence of 4,4'-DDE; 4,4'DDT; and technical chlordane exceeding the MRLs in all the samples. However, the pesticide concentrations were less than the PALs. The analytical results are reported in Table A.7-7. 
Table A.7-6

Soil Sample Result for PCBs Equal to or

Greater than Minimum Reporting Limits at CAS 06-51-03

\begin{tabular}{|c|c|c|c|}
\hline $\begin{array}{c}\text { Sample } \\
\text { Location }\end{array}$ & $\begin{array}{c}\text { Sample } \\
\text { Number }\end{array}$ & $\begin{array}{c}\text { Depth } \\
(\mathrm{ft} \text { bgs) }\end{array}$ & Aroclor 1260 \\
\cline { 3 - 4 } & Preliminary Action Levels & 740 \\
\hline \hline $\mathrm{D} 06$ & $516 \mathrm{D} 008$ & $\begin{array}{c}\text { Interior of Clean-Out } \\
\text { Box }\end{array}$ & $88(\mathrm{~J})$ \\
\hline
\end{tabular}

aU.S. Environmental Protection Agency, Region 9 Preliminary Remediation Goals (PRGs) (EPA, 2002)

$\mathrm{ft}$ bgs = Feet below ground surface

$\mu \mathrm{g} / \mathrm{kg}=$ Micrograms per kilogram

$\mathrm{J}=$ Estimated value. \%D between columns $>25$.

Table A.7-7

Soil Sample Results for Pesticides Equal to or Greater than Minimum Reporting Limits at CAS 06-51-03

\begin{tabular}{|c|c|c|c|c|c|}
\hline \multirow{2}{*}{$\begin{array}{l}\text { Sample } \\
\text { Location }\end{array}$} & \multirow{2}{*}{$\begin{array}{l}\text { Sample } \\
\text { Number }\end{array}$} & \multirow{2}{*}{$\begin{array}{c}\text { Depth } \\
\text { (ft bgs) }\end{array}$} & \multicolumn{3}{|c|}{ Contaminants of Potential Concern $(\mu \mathrm{g} / \mathrm{kg})$} \\
\hline & & & 4,4'-DDE & 4,4'-DDT & $\begin{array}{l}\text { Technical } \\
\text { Chlordane }\end{array}$ \\
\hline \multicolumn{3}{|c|}{ Preliminary Action Levels ${ }^{a}$} & 7,000 & 7,000 & 6,500 \\
\hline D07 & 516D009 & $1.6-1.8$ & $46^{b}$ & 47 & $2,700^{c}$ \\
\hline D08 & $516 \mathrm{D} 010$ & $1.0-1.5$ & $9.6^{\mathrm{b}}$ & $32^{c}$ & $1,700^{c}$ \\
\hline \multirow{2}{*}{ D09 } & $516 \mathrm{D} 011$ & $0-1$ & $19^{b}$ & $47^{c}$ & $2,000^{\mathrm{c}}$ \\
\hline & $516 \mathrm{D} 012$ & $0-1$ & $18^{b}$ & $44^{c}$ & $1,800^{c}$ \\
\hline D10 & $516 \mathrm{D} 013$ & $2.4-2.7$ & $2.3^{\mathrm{b}}$ & 2.6 & 120 \\
\hline D11 & $516 \mathrm{D} 014$ & $0-1$ & $30^{\mathrm{b}, \mathrm{c}}$ & 20 & $760^{c}$ \\
\hline D12 & 516D015 & Inside of Pipe & $31^{\mathrm{b}, \mathrm{c}}$ & 25 & $580^{c}$ \\
\hline
\end{tabular}

aU.S. Environmental Protection Agency, Region 9 Preliminary Remediation Goals (PRGs) (EPA, 2002)

b\%D between columns $>25$

'Surrogates diluted out

$\mathrm{ft}$ bgs $=$ Feet below ground surface

$\mu \mathrm{g} / \mathrm{kg}=$ Micrograms per kilogram 
For waste characterization purposes, additional samples were collected on January 9, 2004. The samples were collected from locations D07, D08, D09, D10, D11, and D12 and analyzed for TCLP chlordane. All the reported concentrations were less than the PALs.

\section{A.7.3.7 Gamma Spectroscopy Analytical Results for Soil Samples}

The gamma spectroscopy results equal to or greater than the MDCs are shown in Table A.7-8. The concentrations of the gamma-emitting radionuclides were compared to the PALs provided in ROTC No. 1 to the CAIP. The gamma spectroscopy results were below the PALs.

Table A.7-8

Soil Sample Results for Gamma-Emitting Radionuclides Equal to or Greater than Minimum Detectable Concentrations at CAS 06-51-03

\begin{tabular}{|c|c|c|c|c|c|c|c|}
\hline \multirow{2}{*}{$\begin{array}{c}\text { Sample } \\
\text { Location }\end{array}$} & \multirow{2}{*}{$\begin{array}{c}\text { Sample } \\
\text { Number }\end{array}$} & \multirow{2}{*}{$\begin{array}{c}\text { Depth } \\
\text { (ft bgs) }\end{array}$} & \multicolumn{5}{|c|}{ Contaminants of Potential Concern (pCi/g) } \\
\cline { 4 - 8 } & & & Actinium-228 & Bismuth-214 & Lead-212 & Lead-214 & Thallium-208 \\
\hline \multicolumn{2}{|c|}{ Preliminary Action Levels ${ }^{\text {a }}$} & $\mathbf{1 5}$ & $\mathbf{1 5}$ & $\mathbf{1 5}$ & $\mathbf{1 5}$ & $\mathbf{1 5}$ \\
\hline \hline D01 & $516 \mathrm{D} 001$ & $2.0-3.0$ & $1.17 \pm 0.35$ & $0.82 \pm 0.26$ & $1.23 \pm 0.28$ & $1.06 \pm 0.25$ & $0.48 \pm 0.15$ \\
\hline D05 & $516 \mathrm{D} 005$ & $2.0-3.0$ & $1.56 \pm 0.39$ & $1.05 \pm 0.27$ & $1.89 \pm 0.37$ & $1.26 \pm 0.27$ & $0.44 \pm 0.13$ \\
\hline D06 & $516 \mathrm{D} 006$ & $\begin{array}{c}\text { Interior of } \\
\text { Clean-Out Box }\end{array}$ & $1.14 \pm 0.32$ & $1.09 \pm 0.28$ & $1.4 \pm 0.3$ & $0.92 \pm 0.23$ & $0.42 \pm 0.12$ \\
\hline
\end{tabular}

${ }^{a}$ Taken from the generic guidelines for residual concentrations of Radium-226, Radium-228, Thorium-230, and Thorium-232 as found in Chapter IV of DOE Order 5400.5,Change 2, "Radiation Protection of the Public and Environment." The PAL for these isotopes is specified as $5 \mathrm{pCi} / \mathrm{g}$ average over the first 15 centimeters of soil and $15 \mathrm{pCi} / \mathrm{g}$ for deeper soils. For purposes of this document, 15 centimeters is assumed to be equivalent to $0.5 \mathrm{ft}$ (6 in.) (DOE, 1993).

$\mathrm{ft}$ bgs $=$ Feet below ground surface

$\mathrm{pCi} / \mathrm{g}=$ Picocuries per gram

\section{A.7.3.8 Isotopic Plutonium Analytical Results for Soil Samples}

Isotopic plutonium analytical results for soil samples with concentrations equal to or greater than the MDCs are reported in Table A.7-9. The concentrations of isotopic plutonium were less than the PALs.

\section{A.7.3.9 Strontium-90 Analytical Results for Soil Samples}

Strontium-90 concentrations in the soil samples were less than the MDCs. 
Table A.7-9

Soil Sample Results for Isotopic Plutonium

Equal to or Greater than Minimum Detectable Concentrations at CAS 06-51-03

\begin{tabular}{|c|c|c|c|}
\hline $\begin{array}{c}\text { Sample } \\
\text { Location }\end{array}$ & $\begin{array}{c}\text { Sample } \\
\text { Number }\end{array}$ & $\begin{array}{c}\text { Depth } \\
\text { (ft bgs) }\end{array}$ & Plutonium-239 \\
\cline { 3 - 4 } & Preliminary Action Levels ${ }^{\mathrm{a}}$ & $\mathbf{7 . 6 2}$ \\
\hline \hline D05 & $516 \mathrm{D} 005$ & $2.0-3.0$ & $0.074 \pm 0.033$ \\
\hline D06 & $516 \mathrm{D} 006$ & Interior of Clean-Out Box & $0.077 \pm 0.032$ \\
\hline
\end{tabular}

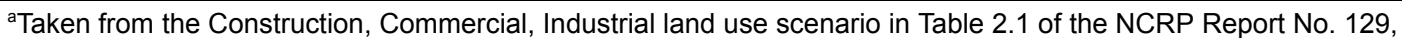

Recommended Screening Limits for Contaminated Surface Soil and Review Factors Relevant to Site-Specific Studies

(NCRP, 1999). The values provided in this source document were scaled to a 15-mrem per year dose.

$\mathrm{ft}$ bgs $=$ Feet below ground surface

$\mathrm{pCi} / \mathrm{g}=$ Picocuries per gram

$\mathrm{LT}=$ Result is less than requested minimum detectable concentration, greater than specific minimum detectable concentration

\section{A.7.3.10 Waste Characterization Analytical Results}

The TPH-DRO concentration $(180 \mathrm{mg} / \mathrm{kg})$ in the contents of the clean-out box exceeds the action level of $100 \mathrm{ppm}$ (NAC, 2003). The concrete clean-out box by association is considered contaminated and will be a waste stream for this CAS upon removal during corrective action activities.

The analytical results for TCLP chlordane were nondetect for all seven samples.

\section{A.7.4 Contaminants of Concern}

Contaminants of concern are present in the clean-out box. The sample (516D008) collected from the clean-out box contents contains TPH-DRO at a concentration that exceeds the PAL. No other COCs were detected in the soil samples. No radiological COCs were identified that exceeded regulatory waste criteria.

\section{A.7.5 Nature and Extent of Contamination}

Total petroleum hydrocarbons were identified in the soil material in the clean-out box exceeding the action level of $100 \mathrm{ppm}$ (NAC, 2003). At sample locations immediately around and beneath the clean-out box, there were no concentrations of TPH-DRO equal to or greater than the MRLs. The 
data show that the contamination is confined to inside the clean-out box. Approximately $0.5 \mathrm{yd}^{3}$ of TPH-DRO contaminated sediment is in the clean-out box.

\section{A.7.6 Revised Conceptual Site Model}

Total pesticides and TCLP chlordane were added to the analytical suite for this CAS as a result of interference observed during PCB analysis indicating the potential presence of pesticides. However, no changes were necessary to the CSM presented in the CAIP (NNSA/NSO, 2003). 


\section{A.8.0 CAS 22-19-04, Vehicle Decontamination Area}

Corrective Action Site 22-19-04, Vehicle Decontamination Area, was associated with Camp Desert Rock which was in operation from 1951 to 1964; this CAS was used as a secondary and/or tertiary decontamination area. The primary and/or secondary decontamination was typically performed at the site of exposure. The CAS is located about $800 \mathrm{ft}$ southwest of the Area 22 Weather Station. Historical documentation states that the site may have unknown buried material; however, a geophysical survey (SAIC, 2001) indicated that there is no buried metallic material present at the site.

The rock-lined washdown area is about $30 \mathrm{ft}$ long and $12 \mathrm{ft}$ wide at the north end and $9 \mathrm{ft}$ wide at the south end (Figure A.8-1). The rock ranges in size from approximately 5 to $10 \mathrm{in}$. in diameter and the depth of the rock is about $16 \mathrm{in}$. The trench is approximately $30 \mathrm{ft}$ long and about $2 \mathrm{ft}$ deep. There is a shallow surface drainage channel that has cut into the trench on the north side about three-quarters of the way from the rock-lined washdown area to the sump. The sump is oval shaped and approximately 7 by $10.5 \mathrm{ft}$ and approximately $2 \mathrm{ft}$ deep. The mounding of soil around the features of the CAS range from 0.5 to $2 \mathrm{ft}$ high. Additional details are provided in the CAIP (NNSA/NSO, 2003).

\section{A.8.1 Corrective Action Investigation}

A total of six environmental soil samples (including one duplicate) from five locations were collected during investigation activities conducted at CAS 22-19-04. These samples were analyzed for the parameters listed in Table A.8-1. Three water samples were also submitted for QC purposes. The sample locations are shown in Figure A.8-1. The specific CAI activities conducted to satisfy the CAIP requirements at CAS 22-19-04 are described in Table A.2-1.

\section{A.8.1.1 Deviations}

There were no deviations from the investigation activities specified in the CAIP for CAS 22-09-04.

\section{A.8.2 Investigation Activities}

The following sections provide descriptions of the CAS-specific activities conducted to complete Phase I activities as outlined in the CAIP. Investigation activities included field screening and sampling of surface and subsurface soils, within the septic system components. 


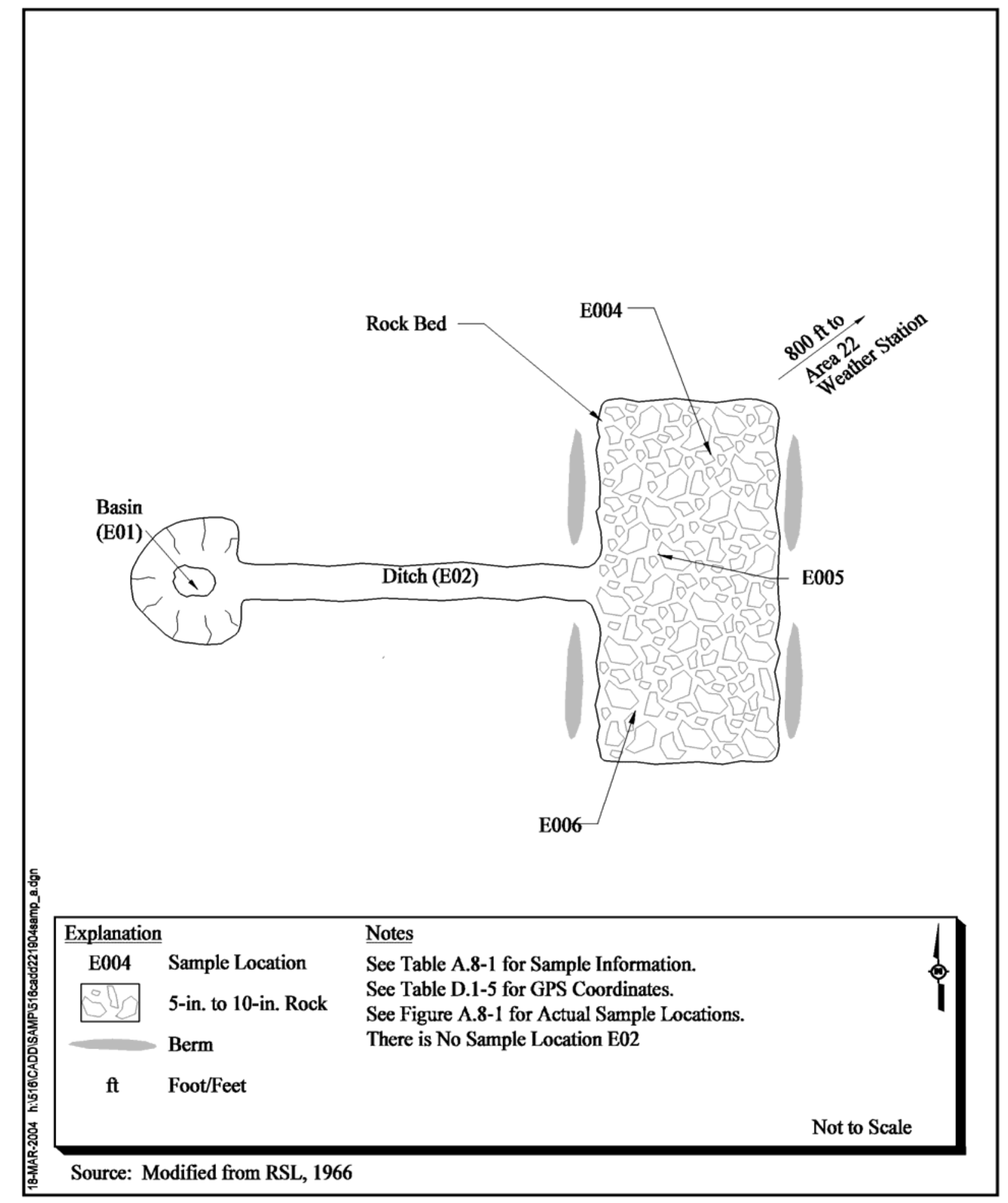

Figure A.8-1

CAU 516, CAS 22-19-04, Vehicle Decontamination Area, Sample Locations 
Table A.8-1

Samples Collected from CAS 22-19-04

\begin{tabular}{|c|c|c|c|c|c|c|c|c|c|c|}
\hline $\begin{array}{l}\text { Sample } \\
\text { Location }\end{array}$ & $\begin{array}{l}\text { Sample } \\
\text { Number }\end{array}$ & $\begin{array}{c}\text { Depth } \\
\text { (ft bgs) }\end{array}$ & $\begin{array}{c}\text { Sample } \\
\text { Matrix }\end{array}$ & Purpose & 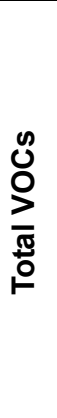 & 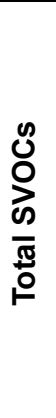 & 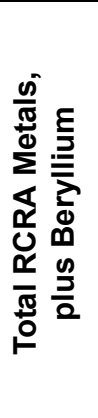 & 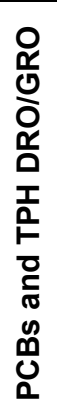 & 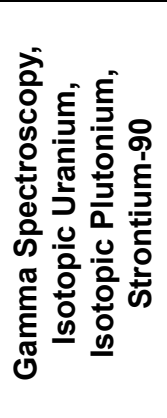 & 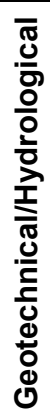 \\
\hline \multirow{3}{*}{ E01 } & 516E001GEO & $0-1$ & Soil & Geotechnical & -- & -- & -- & -- & -- & $\overline{\bar{x}}$ \\
\hline & 516E001 & $0-1$ & Soil & Environmental & $\mathrm{X}$ & $\mathrm{X}$ & $x$ & $\bar{x}$ & $x$ & -- \\
\hline & 516E002 & $0-1$ & Soil & $\begin{array}{c}\text { Duplicate of } \\
516 \mathrm{E} 001\end{array}$ & $x$ & $x$ & $x$ & $x$ & $x$ & -- \\
\hline E03 & $516 \mathrm{E} 003$ & $0-1$ & Soil & Environmental & $x$ & $x$ & $x$ & $x$ & $x$ & - \\
\hline E04 & 516E004 & $0-1$ & Soil & Environmental & $\mathrm{X}$ & $x$ & $\mathrm{x}$ & $x$ & $x$ & - \\
\hline E05 & 516E005 & $0-1$ & Soil & Environmental & $\mathrm{X}$ & $\bar{x}$ & $x$ & $x$ & $x$ & - \\
\hline E06 & 516E006 & $0-1$ & Soil & Environmental & $\mathrm{X}$ & $x$ & $x$ & $x$ & $\mathrm{X}$ & -- \\
\hline \multirow{3}{*}{ NA } & $516 \mathrm{E} 301$ & NA & Water & Trip Blank & $\mathrm{x}$ & -- & -- & -- & -- & -- \\
\hline & 516E302 & NA & Water & Field Blank & $\mathrm{X}$ & $x$ & $\mathrm{X}$ & $x$ & $\mathrm{x}$ & -- \\
\hline & $516 \mathrm{E} 303$ & NA & Water & Rinsate Blank & $\mathrm{X}$ & $x$ & $\mathrm{x}$ & $\mathrm{x}$ & $\mathrm{x}$ & -- \\
\hline
\end{tabular}

NA = Not applicable

$--=$ Not analyzed

\section{A.8.2.1 Field Screening}

All soil samples were screened for VOCs, TPH, and alpha and beta/gamma radiation. The FSRs were compared to FSLs to guide subsequent sampling decisions.

The FSL established for VOC was 20 ppm. Field-screening soil samples for TPH was conducted using a gas chromatograph. The TPH FSL was established at $75 \mathrm{ppm}$. The FSLs less than $75 \mathrm{ppm}$ are considered to be below the action level of $100 \mathrm{ppm}$ (NAC, 2003).

The VOC and alpha and beta/gamma radiation FSLs were not exceeded during sampling activities. The TPH FSL was exceeded for sample 516E004 (collected between 0.0 and $1.0 \mathrm{ft}$ bgs at location E04). The FSR for location E04 was 106 ppm. 


\section{A.8.2.2 Intrusive Investigation Activities}

Phase I sampling activities involved collecting surface soil samples at the rock and native soil interface within the lowest point in the sump at location E01, in the connecting trench at location E03, and at locations E04, E05, and E06 in the rock-lined washdown area. The depth to the rock and native soil interface ranges between 1 to 16 in. (NNSA/NSO, 2003).

One geotechnical sample was collected from undisturbed soil beneath the rock and native soil interface at location E01 in the sump. This sample was not analyzed. It has been archived and will be analyzed for geotechnical parameters if required during the corrective action.

\section{A.8.2.3 Waste Characterization}

Waste characterization activities conducted at CAS 22-19-04 included a visual assessment. The following sections discuss the waste characterization activities.

\section{A.8.2.3.1 Visual Assessment}

The area within and around the CAS boundary was visually inspected for the presence of stains or other waste material. There was no visible staining on the sump, trench, or washdown area.

\section{A.8.2.4 Sample Analysis}

Investigation samples were analyzed for CAIP-specific COPCs that included total VOCs, total SVOCs, total RCRA metals, total beryllium, TPH (DRO/GRO), PCBs, isotopic U, isotopic Pu, Sr-90, and gamma-emitting radionuclides. The analytical parameters and laboratory methods used to analyze the investigation samples are listed in Table A.2-2. Table A.8-1 lists the specific analytical suite for CAS 22-19-04.

\section{A.8.3 Analytes Detected Above Minimum Reporting Limits}

Analytical results from the soil samples with concentrations equal to or greater than the MRLs (NNSA/NSO, 2003) are summarized in the following sections. These nonradiological results are compared to PALs and are a subset of the results that exceed MRLs. Radiological results were compared to the PALs listed in ROTC No.1 of the CAIP (NNSA/NSO, 2003). Results greater than 
PALs are identified by bold text in the analytical tables. The complete data set is maintained in the project file as hard copy and in electronic format.

\section{A.8.3.1 Total Volatile Organic Compound Analytical Results for Soil Samples}

Total VOC analytical results for soil samples equal to or greater than the MRLs are reported in Table A.8-2. All VOC concentrations were below the PALs.

Table A.8-2

Soil Sample Results for Total VOCs

Equal to or Greater than Minimum Reporting Limits at CAS 22-19-04

\begin{tabular}{|c|c|c|c|c|}
\hline \multirow{2}{*}{$\begin{array}{l}\text { Sample } \\
\text { Location }\end{array}$} & \multirow{2}{*}{$\begin{array}{l}\text { Sample } \\
\text { Number }\end{array}$} & \multirow{2}{*}{$\begin{array}{l}\text { Depth } \\
\text { (ft bgs) }\end{array}$} & \multicolumn{2}{|c|}{ Contaminants of Potential Concern $(\mu \mathrm{g} / \mathrm{kg})$} \\
\hline & & & Acetone & Methylene Chloride \\
\hline \multicolumn{3}{|c|}{ Preliminary Action Levels ${ }^{a}$} & $6,000,000$ & 21,000 \\
\hline \multirow{2}{*}{ E01 } & $516 \mathrm{E} 001$ & $0.0-1.0$ & -- & $23(\mathrm{~B})$ \\
\hline & $516 \mathrm{E} 002$ & $0.0-1.0$ & -- & $22(\mathrm{~B})$ \\
\hline E03 & 516E003 & $0.0-1.0$ & -- & $17(\mathrm{~B})$ \\
\hline E04 & $516 E 004$ & $0.0-1.0$ & -- & $17(\mathrm{~B})$ \\
\hline E05 & 516E005 & $0.0-1.0$ & $22(J)^{b}$ & $26(B)$ \\
\hline E06 & 516E006 & $0.0-1.0$ & $27(J)^{c}$ & -- \\
\hline
\end{tabular}

aU.S. Environmental Protection Agency, Region 9 Preliminary Remediation Goals (PRGs) (EPA, 2002)

${ }^{\mathrm{b}}$ Average relative response factor $<0.05$. Relative response factor $<0.05$.

${ }^{c}$ Matrix effects may exist. Average relative response factor $<0.05$. Relative response factor $<0.05$. Surrogate recovery exceeded the lower limits.

$\mathrm{ft}$ bgs $=$ Feet below ground surface

$\mu \mathrm{g} / \mathrm{kg}=$ Micrograms per kilogram

$--=$ Not detected at concentrations equal to or greater than minimum reporting limits

$\mathrm{B}=$ Analyte found in both sample and associated blank

$\mathrm{J}=$ Estimated value

\section{A.8.3.2 Total Semivolatile Organic Compound Analytical Results for Soil Samples}

Total SVOC analytical results for soil samples were less than the MRLs. 


\title{
A.8.3.3 Total RCRA Metal Analytical Results for Soil Samples
}

Results for total metals equal to or greater than the MRLs are reported in Table A.8-3. The concentrations of the RCRA metals and beryllium were less than the PALs.

Table A.8-3

Soil Sample Results for Total RCRA Metals, Plus Beryllium Equal to or Greater than Minimum Reporting Limits at CAS 22-19-04

\begin{tabular}{|c|c|c|c|c|c|c|c|}
\hline \multirow{2}{*}{$\begin{array}{l}\text { Sample } \\
\text { Location }\end{array}$} & \multirow{2}{*}{$\begin{array}{l}\text { Sample } \\
\text { Number }\end{array}$} & \multirow{2}{*}{$\begin{array}{l}\text { Depth } \\
\text { (ft bgs) }\end{array}$} & \multicolumn{5}{|c|}{ Contaminants of Potential Concern (mg/kg) } \\
\hline & & & Arsenic & Barium & Beryllium & Chromium & Lead \\
\hline \multicolumn{3}{|c|}{ Preliminary Action Levels } & $23^{a}$ & $67,000^{b}$ & $1,900^{b}$ & $450^{b}$ & $750^{b}$ \\
\hline \multirow{2}{*}{ E01 } & 516E001 & $0.0-1.0$ & 5.1 & $98(\mathrm{~J})$ & $0.52(\mathrm{~J})$ & 6.2 & 13 \\
\hline & 516E002 & $0.0-1.0$ & 5 & $95(\mathrm{~J})$ & $0.51(\mathrm{~J})$ & 6 & 13 \\
\hline E03 & 516 E003 & $0.0-1.0$ & 5.2 & $78(\mathrm{~J})$ & -- & 5.1 & 9.9 \\
\hline E04 & 516E004 & $0.0-1.0$ & 5.7 & $100(\mathrm{~J})$ & $0.6(\mathrm{~J})$ & 7.4 & 12 \\
\hline E05 & 516E005 & $0.0-1.0$ & 6.3 & $100(\mathrm{~J})$ & 0.69 (J) & 8.4 & 12 \\
\hline E06 & 516E006 & $0.0-1.0$ & 5.7 & $99(\mathrm{~J})$ & $0.61(\mathrm{~J})$ & 8 & 19 \\
\hline
\end{tabular}

${ }^{a}$ Based on the background concentrations for metals. Background is considered the mean plus two times the standard deviation for sediment samples collected by the Nevada Bureau of Mines and Geology throughout the Nevada Test and Training Range (NBMG, 1998; Moore, 1999).

bU.S. Environmental Protection Agency, Region 9 Preliminary Remediation Goals (PRGs) (EPA, 2002)

\author{
$\mathrm{ft}$ bgs $=$ Feet below ground surface \\ $\mathrm{mg} / \mathrm{kg}=$ Milligrams per kilogram \\ -- = Not detected at concentrations equal to or greater than minimum reporting limits \\ $\mathrm{J}=$ Estimated value. ICP serial dilution \%D outside control limits. Matrix effects may exist.
}

\section{A.8.3.4 Total Petroleum Hydrocarbon Analytical Results for Soil Samples}

Total petroleum hydrocarbon analytical results for soil samples equal to or greater than MRLs are reported in Table A.8-4. The TPH concentrations were less than the PAL.

\section{A.8.3.5 Polychlorinated Biphenyl Analytical Results for Soil Samples}

The PCB analytical results for soil samples were less than the MRLs. 
Table A.8-4

Soil Sample Results for TPH-DRO Equal to or Greater than Minimum Reporting Limits at CAS 22-19-04

\begin{tabular}{|c|c|c|c|}
\hline \multirow{2}{*}{$\begin{array}{c}\text { Sample } \\
\text { Location }\end{array}$} & $\begin{array}{c}\text { Sample } \\
\text { Number }\end{array}$ & $\begin{array}{c}\text { Depth } \\
\text { (ft bgs) }\end{array}$ & Contaminants of Potential Concern (mg/kg) \\
\cline { 4 - 4 } & \multicolumn{2}{|c|}{ Preliminary Action Levels ${ }^{\mathrm{a}}$} & 100 \\
\hline \hline E04 & $516 \mathrm{E} 004$ & $0.0-1.0$ & Diesel-Range Organics \\
\hline E05 & $516 \mathrm{E} 005$ & $0.0-1.0$ & $10(\mathrm{H}, \mathrm{Z})$ \\
\hline $\mathrm{E} 06$ & $516 \mathrm{E} 006$ & $0.0-1.0$ & $17(\mathrm{H}, \mathrm{Z})$ \\
\hline
\end{tabular}

aNevada Administrative Code, "Water Controls" (NAC, 2002)

$\mathrm{ft}$ bgs = Feet below ground surface $\mathrm{mg} / \mathrm{kg}=$ Milligrams per kilogram

$\mathrm{H}=$ The fuel pattern was in the heavier end of the retention time window for the analyte of interest.

$Z$ = A significant fraction of the reported result did not resemble the patterns of the following petroleum hydrocarbon products: Gasoline, JP-4, JP-8, diesel, mineral spirits, motor oil, Stoddard solvent, and Bunker C.

\section{A.8.3.6 Gamma Spectroscopy Analytical Results for Soil Samples}

Gamma spectroscopy results equal to or greater than the MDCs are shown in Table A.8-5. Gamma spectroscopy concentrations were less than the PALs.

\section{A.8.3.7 Isotopic Uranium and Isotopic Plutonium Analytical Results for Soil Samples}

Isotopic uranium analytical results for soil samples are shown in Table A.8-6. The concentrations of isotopic uranium were less than the PALs.

\section{A.8.3.8 Strontium-90 Analytical Results for Soil Samples}

Strontium-90 concentration for soil samples were less that the MDCs.

\section{A.8.4 Contaminants of Concern}

No contaminants of concern are present in CAS 22-19-04. There were no radiological COPCs identified in the soil that exceeded unrestricted release criteria. 
Table A.8-5

Soil Sample Results for Gamma-Emitting Radionuclides Equal to or Greater than Minimum Detectable Concentrations at CAS 22-19-04

\begin{tabular}{|c|c|c|c|c|c|c|c|c|}
\hline \multirow[b]{2}{*}{$\begin{array}{l}\text { Sample } \\
\text { Location }\end{array}$} & \multirow[b]{2}{*}{$\begin{array}{l}\text { Sample } \\
\text { Number }\end{array}$} & \multirow[b]{2}{*}{$\begin{array}{c}\text { Depth } \\
\text { (ft bgs) }\end{array}$} & \multicolumn{6}{|c|}{ Contaminants of Potential Concern (pCi/g) } \\
\hline & & & 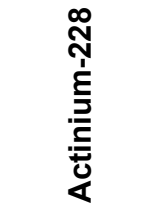 & 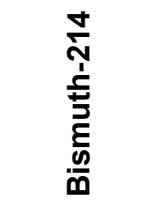 & 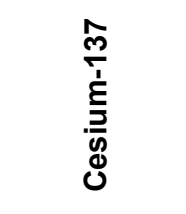 & 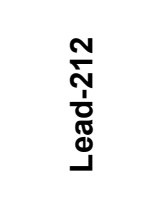 & 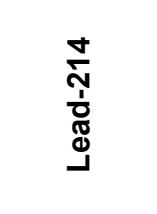 & 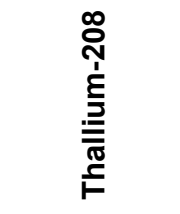 \\
\hline \multicolumn{3}{|c|}{ Preliminary Action Levels } & $5^{\mathrm{a}}$ & $5^{a}$ & $7.30^{b}$ & $5^{a}$ & $5^{a}$ & $5^{\mathrm{a}}$ \\
\hline \multirow{2}{*}{ E01 } & 516E001 & $0.0-1.0$ & $0.64 \pm 0.22$ & $0.53 \pm 0.18$ & $0.37 \pm 0.11$ & $0.8 \pm 0.19$ & $0.54 \pm 0.16$ & $0.28 \pm 0.1$ \\
\hline & 516E002 & $0.0-1.0$ & -- & $0.61 \pm 0.2$ & $0.3 \pm 0.1$ & $0.73 \pm 0.18$ & $0.51 \pm 0.14$ & $0.257 \pm 0.096$ \\
\hline E03 & 516E003 & $0.0-1.0$ & -- & $0.38 \pm 0.15$ & -- & $0.57 \pm 0.15$ & $0.42 \pm 0.13$ & $0.175 \pm 0.072$ \\
\hline E04 & 516E004 & $0.0-1.0$ & $0.79 \pm 0.21$ & $0.4 \pm 0.14$ & $0.386 \pm 0.092$ & $0.86 \pm 0.17$ & $0.68 \pm 0.15$ & $0.235 \pm 0.068$ \\
\hline E05 & 516E005 & $0.0-1.0$ & $0.98 \pm 0.23$ & $0.53 \pm 0.15$ & $0.317 \pm 0.084$ & $1.03 \pm 0.2$ & $0.67 \pm 0.15$ & $0.314 \pm 0.083$ \\
\hline E06 & 516E006 & $0.0-1.0$ & $0.84 \pm 0.28$ & $0.62 \pm 0.21$ & $1.03 \pm 0.23$ & $1 \pm 0.24$ & $0.76 \pm 0.2$ & $0.3 \pm 0.1$ \\
\hline
\end{tabular}

aTaken from the generic guidelines for residual concentrations of Radium-226, Radium-228, Thorium-230, and Thorium-232 as found in Chapter IV of DOE Order 5400.5, Change 2, "Radiation Protection of the Public and Environment." The PAL for these isotopes is specified as $5 \mathrm{pCi} / \mathrm{g}$ averaged over the first 15 centimeters of soil and $15 \mathrm{pCi} / \mathrm{g}$ for deeper soils. For purposes of this document, 15 centimeters is assumed to be equivalent to $0.5 \mathrm{ft}$ (6 in.) (DOE, 1993).

${ }^{\mathrm{b}}$ Taken from the Construction, Commercial, Industrial land use scenario in Table 2.1 of the NCRP Report No. 129, Recommended Screening Limits for Contaminated Surface Soil and Review Factors Relevant to Site-Specific Studies (NCRP, 1999). The values provided in this source document were scaled to a 15-mrem per year dose.

$\mathrm{ft}$ bgs $=$ Feet below ground surface

$\mathrm{pCi} / \mathrm{g}=$ Picocuries per gram

-- = Not detected equal to or greater than minimum detectable concentrations

\section{A.8.5 Revised Conceptual Site Model}

No variations to the conceptual site model were identified. 
Table A.8-6

Soil Sample Results for Isotopic Plutonium and Uranium Equal to or Greater than Minimum Detectable Concentrations at CAS 22-19-04

\begin{tabular}{|c|c|c|c|c|c|c|}
\hline \multirow{2}{*}{$\begin{array}{l}\text { Sample } \\
\text { Location }\end{array}$} & \multirow{2}{*}{$\begin{array}{l}\text { Sample } \\
\text { Number }\end{array}$} & \multirow{2}{*}{$\begin{array}{l}\text { Depth } \\
\text { (ft bgs) }\end{array}$} & \multicolumn{4}{|c|}{ Contaminants of Potential Concern (pCi/g) } \\
\hline & & & Plutonium-239 & Uranium-234 & Uranium-235 & Uranium-238 \\
\hline \multicolumn{3}{|c|}{ Preliminary Action Levels ${ }^{a}$} & 7.62 & 85.9 & 10.5 & 63.2 \\
\hline \multirow{2}{*}{ E01 } & $516 \mathrm{E} 001$ & $0.0-1.0$ & -- & $0.446 \pm 0.096$ & -- & $0.58 \pm 0.12$ \\
\hline & $516 \mathrm{E} 002$ & $0.0-1.0$ & - & $0.426 \pm 0.095$ & -- & $0.454 \pm 0.099$ \\
\hline E03 & 516E003 & $0.0-1.0$ & -- & $0.46 \pm 0.1$ & $0.076 \pm 0.038$ & $0.51 \pm 0.11$ \\
\hline E04 & 516E004 & $0.0-1.0$ & $0.121 \pm 0.052$ & $0.64 \pm 0.13$ & - & $0.416 \pm 0.095$ \\
\hline E05 & 516E005 & $0.0-1.0$ & -- & $0.61 \pm 0.12$ & -- & $0.53 \pm 0.11$ \\
\hline E06 & 516E006 & $0.0-1.0$ & $0.178 \pm 0.065$ & $0.63 \pm 0.13$ & $\overline{--}$ & $0.53 \pm 0.11$ \\
\hline
\end{tabular}

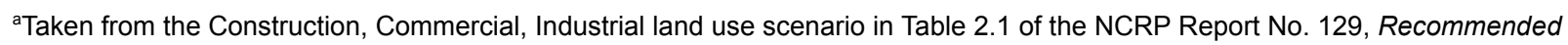
Screening Limits for Contaminated Surface Soil and Review Factors Relevant to Site-Specific Studies (NCRP, 1999). The values provided in this source document were scaled to a $15-\mathrm{mrem}$ per year dose.

$\mathrm{ft}$ bgs $=$ Feet below ground surface

$\mathrm{pCi} / \mathrm{g}=$ Picocuries per gram

-- = Not detected at concentrations equal to or greater than minimum detectable concentrations 


\section{A.9.0 Waste Management}

Waste minimization was integrated into the field activities. Investigation-derived waste was segregated to the greatest extent possible. Controls were in place to minimize the use of hazardous materials and the unnecessary generation of hazardous and/or mixed waste. Decontamination activities were planned and executed to minimize the volume of rinsate generated.

Potentially hazardous waste generated during the investigation was placed in 55-gal steel drums and labeled as "Hazardous Waste - Pending Analysis." Three Hazardous Waste Accumulation Areas (HWAAs) were established to manage the waste generated during the CAI. The amount, type, and source of waste placed into each drum were recorded in the waste management logbook at the time of generation.

\section{A.9.1 Characterization}

Analytical results for each drum of waste or associated samples were reviewed through Tier I, II, and III validation. This was accomplished to ensure compliance with federal and state regulations, DOE directives/policies, guidance, waste disposal criteria, and other approved procedures.

\section{A.9.2 Waste Streams}

Investigation-derived waste generated during the investigation was segregated into the following waste streams:

- Personal protective equipment (PPE)

- Decontamination rinsate

- Debris including, but not limited to: plastic sheeting, disposable sampling equipment and bowls, glass sample jars, and soil

\section{A.9.3 Investigation-Derived Waste Generated}

A total of 18 drums of IDW were generated during the investigation and classified as follows:

- Twelve drums have been declared sanitary waste for disposal at the NTS. 
- Six drums of waste are considered hazardous waste pending analytical results.

Additional IDW may be deemed waste during the full demobilization from these CASs. This may include plastic sheeting from the decontamination pads and PPE. 


\section{A.10.0 Quality Assurance}

This section contains a summary of QA/QC measures implemented during the sampling and analysis activities conducted in support of the CAU 516 CAI. The following sections discuss the data validation process, QC samples, and nonconformances. A detailed evaluation of the DQIs is presented in Appendix B.

Laboratory analyses were conducted for samples used in the decision-making process to provide a quantitative measurement of any COPCs present. Rigorous QA/QC was implemented for all laboratory samples including documentation, verification, and validation of analytical results, and affirmation of DQI requirements related to laboratory analysis. Detailed information regarding the QA program is contained in the Industrial Sites QAPP (NNSA/NV, 2002).

\section{A.10.1 Data Validation}

Data validation was performed in accordance with the Industrial Sites QAPP (NNSA/NV, 2002) and approved protocols and procedures. All laboratory data from samples collected and analyzed for CAU 516 were evaluated for data quality according to the EPA Functional Guidelines (EPA, 1994 and 1999). These guidelines are implemented in a tiered process and are presented in Section A.10.1.1 to Section A.10.1.3. Data were reviewed to ensure that samples were appropriately processed and analyzed, and the results were evaluated using validation criteria. Documentation of the data qualifications resulting from these reviews is retained in project files as a hard copy and electronic media.

One hundred percent of the data analyzed as part of this investigation were subjected to Tier I and Tier II evaluations. A Tier III evaluation was performed on approximately five percent of the data analyzed.

\section{A.10.1.1 Tier I Evaluation}

Tier I evaluation for chemical and radiochemical analysis examines, but is not limited to:

- Sample count/type consistent with chain of custody

- Analysis count/type consistent with chain of custody 
- Correct sample matrix

- Significant problems stated in cover letter or case narrative

- Completeness of certificates of analysis

- Completeness of Contract Laboratory Program (CLP) or CLP-like packages

- Completeness of signatures, dates, and times on chain of custody

- Condition-upon-receipt variance form included

- Requested analyses performed on all samples

- Date received/analyzed given for each sample

- Correct concentration units indicated

- Electronic data transfer supplied

- Results reported for field and laboratory QC samples

- Whether or not the deliverable met the overall objectives of the project

\section{A.10.1.2 Tier II Evaluation}

Tier II evaluation for chemical and radiochemical analysis examines, but is not limited to:

\section{Chemical:}

- Correct detection limits achieved

- Sample date, preparation date, and analysis date for each sample

- Holding time criteria met

- Quality control batch association for each sample

- Cooler temperature upon receipt

- Sample $\mathrm{pH}$ for aqueous samples, as required

- Detection limits properly adjusted for dilution, as required

- Blank contamination evaluated and applied to sample results/qualifiers

- $\quad$ MS/MSD percent recovery (\%R) and relative percent differences (RPDs) evaluated and qualifiers applied to laboratory results, as necessary

- Field duplicate RPDs evaluated using professional judgment and qualifiers applied to laboratory results, as necessary

- Laboratory duplicate RPDs evaluated and qualifiers applied to laboratory results, as necessary

- Surrogate $\% \mathrm{R}$ evaluated and qualifiers applied to laboratory results, as necessary

- Laboratory control sample (LCS) \%R evaluated and qualifiers applied to laboratory results, as necessary

- Initial and continuing calibration evaluated and qualifiers applied to laboratory results, as necessary 
- Internal standard evaluation

- Mass spectrometer tuning criteria

- Organic compound quantitation

- Inductively coupled plasma interference check sample evaluation

- Graphite furnace atomic absorption quality control

- Inductively coupled plasma serial dilution effects

- Recalculation of 10 percent of laboratory results from raw data

\section{Radioanalytical:}

- Correct detection limits achieved

- Blank contamination evaluated and, if significant, qualifiers are applied to sample results

- Certificate of Analysis consistent with data package documentation

- Quality control sample results (duplicates, laboratory control samples, laboratory blanks) evaluated and used to determine laboratory result qualifiers

- Sample results, uncertainty, and minimum detectable concentration evaluated

- Detector system calibrated with National Institute for Standards and Technology (NIST)traceable sources

- Calibration sources preparation was documented, demonstrating proper preparation and appropriateness for sample matrix, emission energies, and concentrations

- Detector system response to daily or weekly background and calibration checks for peak energy, peak centroid, peak full-width half-maximum, and peak efficiency, depending on the detection system

- Tracers NIST-traceable, appropriate for the analysis performed, and recoveries that met QC requirements

- Documentation of all QC sample preparation complete and properly performed

- Spectra lines, photon emissions, particle energies, peak areas, and background peak areas support the identified radionuclide and its concentration

\section{A.10.1.3 Tier III}

The Tier III review is a data validation of a limited number of samples (typically 5 percent) by an independent agency. This validation encompasses a complete validation of the analytical results 
according the EPA functional guidelines and equivalent industry standard protocol. Tier III data validations include the following:

\section{Chemical:}

- Recalculation of all laboratory results from raw data

\section{Radioanalytical:}

- QC sample results (e.g., calibration source concentration, \%R, and RPD) verified

- Radionuclides and their concentration validated as appropriate considering their decay schemes, half-lives, process knowledge, and history of the facility and site

- Each identified line in spectra verified against emission libraries and calibration results

- Independent identification of spectra lines, area under the peaks, and quantification of radionuclide concentration in a random number of sample results

A Tier III review of at least five percent of the sample analytical data was performed by TechLaw, Inc., of Lakewood, Colorado. Tier II and Tier III results were compared and where differences were noted, data were reviewed and changes made accordingly.

\section{A.10.2 Quality Control Samples}

There were 23 trip blanks, 3 equipment rinsate blanks, 7 field blanks, 6 source blanks, 10 MS/MSDs, and 9 field duplicates collected and analyzed for the parameters listed in Table A.2-1. With the exception of MS/MSDs, quality control samples were assigned individual sample numbers and sent to the laboratory "blind."

\section{A.10.2.1 Field Quality Control Samples}

Review of the field blank analytical data for soil sampling indicates that cross contamination from field methods did not occur during sample collection. Field, equipment rinsate, and source blanks were analyzed for the applicable parameters listed in Table A.2-1 and trip blanks were analyzed for VOCs only.

During the sampling events, 9 field duplicates were sent as blind samples to the laboratory to be analyzed for the investigation parameters listed in Table A.2-1. For these samples, the duplicate 
results precision (i.e., RPDs between the environmental sample results and their corresponding field duplicate sample results) were evaluated in accordance with guidance set forth in the EPA Functional Guidelines (EPA, 1994).

\section{A.10.2.2 Laboratory Quality Control Samples}

Analysis of method QC blanks were performed on each sample delivery group (SDG) for inorganics. Analysis for surrogate spikes and preparation blanks (PBs) were performed on each SDG for organics only. Initial and continuing calibration and LCSs were performed for each SDG by Paragon Analytical, Inc. The results of these analyses were used to qualify associated environmental sample results according to the EPA Functional Guidelines (EPA, 1994 and 1999). Documentation of data qualifications resulting from the application of these guidelines is retained in project files as both hard copy and electronic media.

The laboratory included a PB, LCS, and laboratory duplicate (LD) sample with each batch of field samples analyzed for radionuclides.

\section{A.10.3 Field Nonconformances}

There were no field nonconformances identified for the corrective action investigation.

\section{A.10.4 Laboratory Nonconformances}

Laboratory nonconformances are generally due to inconsistencies in the analytical instrumentation operation, sample preparations, extractions, missed holding times, and fluctuations in internal standard and calibration results. Eight nonconformances were issued by the laboratory that resulted in qualifying data and have been accounted for during the data qualification process. 


\section{A.11.0 Summary}

Analytes detected in soil samples during the CAI were evaluated against radiological and nonradiological PALs identified in the CAIP or ROTC No. 1 to the CAIP to determine the nature and extent of COCs for CAU 516. Data generated from investigation activities indicate that the radiological PAL was exceeded in one soil sample at CAS 03-59-02. The TPH-DRO PAL was exceeded in one soil/sediment sample at CAS 06-51-01 and in the contents of the clean-out box at CAS 06-51-03. Data obtained were evaluated against regulatory action levels and radiological release criteria based on waste disposal options. The regulatory action level for TPH-DRO was exceeded for the septic tank contents at CAS 03-59-01 and CAS 03-59-02, for the pipe contents at CAS 06-51-01, and for the clean-out box contents at CAS 06-51-03. The radiological release criteria were exceeded for the septic tank contents at CAS 03-59-02. The following summarizes the results for each CAS.

CAS 03-59-01, Bldg 3C-36 Septic System, includes a septic tank, distribution box, and leachfield. The septic tank contains TPH-DRO contaminated solid material at concentrations of 7,800 (effluent chamber) and 3,600 mg/kg (influent chamber), exceeding the TPH action level of $100 \mathrm{ppm}$. The other septic system components (i.e., distribution box, leachfield, and associated piping) were not contaminated.

CAS 03-59-02, Bldg 3C-45 Septic System, includes a septic tank, distribution box, leachfield, associated piping, and two dry wells. The septic tank contains contaminated liquid and solid waste. The effluent chamber contains TPH-DRO contaminated solids at a concentration of 7,900 mg/kg. The influent chamber contains THP-DRO contaminated solids at $28,000 \mathrm{mg} / \mathrm{kg}$. Gross alpha- and gross beta-radiation were detected in the liquid in the effluent chamber at concentrations of $104 \pm 20$ and $193 \pm 34 \mathrm{pCi} / \mathrm{L}$, respectively, exceeding the NDWS. The chlorinated compounds 1,1-dichloroethene; 1,2-dichloroethane; and trichloroethene were detected in the solids at concentrations of $6,0.96$, and $4 \mathrm{mg} / \mathrm{L}$, respectively. These results exceed the respective RCRA waste action levels of $0.7,0.5$, and $0.5 \mathrm{mg} / \mathrm{L}$. Plutonium-239 was detected in the soil between 5.5 and $6.5 \mathrm{ft}$ bgs at leachfield sample location $\mathrm{B} 06$. The $\mathrm{Pu}-239$ concentration of $7.3+1.1 \mathrm{pCi} / \mathrm{g}$ (conservative value of $8.4 \mathrm{pCi} / \mathrm{g}$ ) exceeds the PAL. The other septic system components (i.e., distribution box, dry wells, and piping) were not contaminated. 
CAS 06-51-01, Sump and Piping, includes a sump and $275 \mathrm{ft}$ of pipe located between Building 660 and the sump. An 82-ft section of pipe contains soil/sediment contaminated with TPH-DRO at a concentration of $220 \mathrm{mg} / \mathrm{kg}$, exceeding the TPH action level of $100 \mathrm{ppm}$. The other septic system components (i.e., sump soil and remaining pipe) were not contaminated.

CAS 06-51-02, Clay Pipe and Debris, was not required to be investigated. Only surface debris existed at this CAS. The surface debris was removed and surveyed for radiation. The survey showed that unrestricted release criteria was not exceeded. The debris was disposed in the NTS 10c Landfill.

CAS 06-51-03, Clean Out Box and Piping, includes a clean-out box containing approximately $0.5 \mathrm{yd}^{3}$ of material contaminated with TPH-DRO at a concentration of $180 \mathrm{mg} / \mathrm{kg}$, exceeding the NAC action level of 100 ppm.

CAS 22-19-04, Vehicle Decontamination Area, includes a sump, trench, and rock-lined washdown area. No COCs were identified in the soil samples collected. 


\section{A.12.0 References}

BN, see Bechtel Nevada.

Bechtel Nevada. 1995. Nevada Test Site Performance Objective for Certification of Nonradioactive Hazardous Waste, Rev. 0, G-E11/96.01. Las Vegas, NV.

CFR, see Code of Federal Regulations.

Code of Federal Regulations. 2003. Title 40 CFR, "Protection of Environment," Parts 260-282,

"Hazardous Waste Management." Washington, DC: U.S. Government Printing Office.

DOE, see U.S. Department of Energy.

DOE/NV, see U.S. Department of Energy, Nevada Operations Office.

DRI, see Desert Research Institute.

Desert Research Institute. 1993. Data Report ER-6-1 Hydrologic Testing and Geochemical Sampling Results, March. Prepared by D.R. Gillespie. Las Vegas, NV: Water Resources Center.

Dodge, R., Bechtel Nevada. 1996. Letter to K.A. Hoar (DOE/NV) entitled, "Status of the Desert Rock Airport Fuel Spill (CAU 329)," 20 June. Las Vegas, NV.

EPA, see U.S. Environmental Protection Agency.

FFACO, see Federal Facility Agreement and Consent Order.

Federal Facility Agreement and Consent Order. 1996 (as amended). Agreed to by the State of Nevada, the U.S. Department of Energy, and the U.S. Department of Defense.

Holmes \& Narver, Inc. 1976. Engineering drawing JS-003-3C-45-C2.1 entitled, "Nevada Test Site Area 3 LASL Building 3C-45 Rack and Compensator Fac. Addition Surface Treatment," 19 January. Mercury, NV: Archives and Records Center.

Holmes \& Narver, Inc. 1985. Engineering drawing JS-003-3C-36-C1.1 entitled, "Nevada Test Site Area 3 - Los Alamos Building No. 3C-36 WX-9 Office Complex Plot \& Grading Plan Details," 23 January. Mercury, NV: Archives and Records Center.

IT Corporation. 2002. Radiological Soil Survey of Selected Sites for Preliminary Assessments Geophysical Sites Fall 2001, 19 January. Las Vegas, NV. 
McCall, B., Shaw Environmental, Inc. 2003. Field sketches of housekeeping site at Corrective Action Unit 516, Corrective Action Site 06-51-02, Clay Pipe and Debris. Las Vegas, NV.

Moore, J., Science Applications International Corporation. 1999. Memorandum to M. Todd (Science Applications International Corporation) entitled, "Background Concentrations for NTS and TTR Soil Samples," 3 February. Las Vegas, NV.

NAC, see Nevada Administrative Code.

NBMG, see Nevada Bureau of Mines and Geology.

NCRP, see National Council on Radiation Protection and Measurements.

NDEP, see Nevada Division of Environmental Protection.

NNSA/NSO, see U.S. Department of Energy, National Nuclear Security Administration Nevada Site Office.

NNSA/NV, see U.S. Department of Energy, National Nuclear Security Administration Nevada Operations Office.

National Council on Radiation Protection and Measurements. 1999. Recommended Screening Limits for Contaminated Surface Soil and Review of Factors Relevant to Site-Specified Studies, Report No. 129. Bethesda, MD.

Nevada Administrative Code. 2003. NAC 445A, "Water Controls.” Carson City, NV.

Nevada Bureau of Mines and Geology. 1998. Mineral and Energy Resource Assessment of the Nellis Air Force Range, Open-File Report 98-1. Reno, NV.

PAI, see Paragon Analytics, Inc.

Paragon Analytics, Inc. 1999-2003. Standard Operating Procedures. Ft. Collins, CO.

REECo, see Reynolds Electrical \& Engineering Co., Inc.

RSL, see Remote Sensing Laboratory.

Remote Sensing Laboratory. 1966. Aerial photographs of CAU 516, CAS 22-19-04. Nellis Air Force Base, NV: Photo Archives Library.

Remote Sensing Laboratory. 1971. Aerial Photograph of Well 3 Yard. Nellis Air Force Base, NV: Photo Archives Library. 
Reynolds Electrical \& Engineering Co., Inc. 1964. Engineering Drawing RE-791A entitled, "U.S. Public Health Service Facilities for Milk Cows Plot Plan," December. Mercury, NV: Archives and Record Center.

SAIC, see Science Applications International Corporation.

Shaw, see Shaw Environmental, Inc.

Science Applications International Corporation. 2001. Surface Geophysical Survey Report Preliminary Assessments Sites, Nevada Test Site, December. Harrisburg, PA.

Shaw Environmental, Inc. 2003. Site-Specific Health and Safety Plan for CAU 516 Septic Systems and Discharge Points, Nevada Test Site, July. Las Vegas, NV.

Shott, G.J., V. Yucel, M.J. Sully, L.E. Barker, S.E. Rawlinson, and B.A. Moore. 1997. Performance Assessment/Composite Analysis for the Area 3 Radioactive Waste Management Site at the Nevada Test Site, Nye County, Nevada, Rev. 2.0. Las Vegas, NV.

USGS, see U.S. Geological Survey.

U.S. Department of Energy. 1993. DOE Order 5400.5, Change 2, "Radiation Protection of the Public and the Environment." Washington, DC.

U.S. Department of Energy, National Nuclear Security Administration Nevada Operations Office. 2002. Industrial Sites Quality Assurance Project Plan, Nevada Test Site, Nevada, Rev. 3, DOE/NV--372. Las Vegas, NV.

U.S. Department of Energy, National Nuclear Security Administration Nevada Site Office. 2003. Corrective Action Investigation Plan for Corrective Action Unit 516: Septic Systems and Discharge Points, Nevada Test Site, Nevada, DOE/NV--889. Las Vegas, NV.

U.S. Environmental Protection Agency. 1987. Data Quality Objectives for Remedial Response Activities, EPA/540/G-87/003. Washington, DC.

U.S. Environmental Protection Agency. 1994. Contract Laboratory Program National Functional Guidelines for Inorganic Data Review, EPA/540/R-94/013. Washington, DC.

U.S. Environmental Protection Agency. 1996. Test Method for Evaluating Solid Waste Physical/Chemical Methods, SW-846, 3rd Edition, CD-ROM PB97-501928GEI. Washington, DC.

U.S. Environmental Protection Agency. 1999. Contract Laboratory Program National Functional Guidelines for Organic Data Review, EPA 540/R-99/008. Washington, DC. 
U.S. Environmental Protection Agency. 2002. Region 9 Preliminary Remediation Goals (PRGs). As accessed at www.epa.gov/region09/waste/sfund/prg/index.htm, 8 January 2003. Prepared by S.J. Smucker. San Francisco, CA.

U.S. Geological Survey. 1964. Summary of Hydraulic Data, Quality of Water, and Lithologic Log for Army Well 1, Mercury Valley, Nye County, Nevada, Technical Letter NTS-71, 15 January. Prepared by G.L. Meyer, and R.E. Smith. Denver, CO.

U.S. Geological Survey. 1975. Hydrogeologic and Hydrochemical Framework, South-Central Great Basin, Nevada-California, with Special Reference to the Nevada Test Site, USGS-PR-712-C. Prepared by I.J. Winogard and W. Thordarson on behalf of the U.S. Atomic Energy Commission. Denver, CO.

Wuellner, J.W., Reynolds Electrical \& Engineering Co., Inc. 1994. Memorandum to J.R. Bielawski (Reynolds Electrical \& Engineering Co., Inc.) entitled, "Historical Information, Area 3 Waste Mud Impoundment," 2 May. Las Vegas, NV. 
Appendix B

Data Assessment of Samples Results for CAU 516 


\section{B.1.0 Data Assessment}

This appendix provides an assessment of the CAU 516 investigation results to determine whether the data collected met the DQOs and can support their intended use in the decision-making process.

Specifically, results of DQIs identified in the Industrial Sites QAPP (NNSA/NV, 2002)

(i.e., precision, accuracy, completeness, representativeness, comparability, and sensitivity) are compared to established criteria in relationship to predetermined DQOs. The DQO process is detailed in Appendix A of the CAU 516 CAIP (NNSA/NSO, 2003). This section discusses and evaluates whether DQIs meet DQO criteria. This assessment also includes a reconciliation of the data with the general CSMs established for this project.

\section{B.1.1 Precision}

Precision is a measure of agreement among a replicate set of measurements of the same property under similar conditions. This agreement is expressed as the RPD between duplicate measurements (EPA, 1996). The RPD is determined by dividing the difference between the replicate measurement values by the average measurement value and multiplying the result by 100 , or:

$$
\operatorname{RPD}=\left|100 \times\left[\left\{\left(a_{1}-a_{2}\right) /\left(a_{1}+a_{2}\right) / 2\right\}\right]\right|
$$

where:

$\mathrm{a}_{1}=$ The sample value

$\mathrm{a}_{2}=$ The duplicate sample value

Determinations of precision can be made for field samples, laboratory duplicates, or both. For field samples, duplicates are collected simultaneously with a sample from the same source under similar conditions in separate containers. The duplicate sample is treated independently of the original sample in order to assess field impacts and laboratory performance on precision through a comparison of results. Laboratory precision is evaluated as part of the required laboratory internal QC program to assess performance of analytical procedures. The laboratory sample duplicates are an aliquot or subset of a field sample generated in the laboratory. They are not a separate sample but 
portions of an existing sample. Typically, other laboratory duplicate QC samples include MSDs and laboratory control samples duplicates (LCSD).

The variability in the results from the analysis of field duplicates is generally greater than the variability in the results of LDs. This higher variability for field duplicates results from the increased potential to introduce factors influencing the analytical results during sampling, sample preparation, containerization, handling, packaging, preservation, and environmental conditions before the samples reach the laboratory. Laboratory QC samples only assess the variability of results introduced by sample handling and preparation in the laboratory and by the analytical procedure, which also impacts field duplicates. In addition, the variability in duplicate results is expected to be greater for soil samples than water samples, primarily due to the inherent heterogeneous nature of soil samples, despite sample preparation methods that include mixing to improve sample homogeneity.

\section{B.1.1.1 Precision for Chemical Analysis}

The RPD criteria used for assessment of laboratory sample duplicate precision for analytical results of samples collected at CAU 516 were established as follows:

- Inorganic analysis RPD criteria is obtained from the EPA's Contract Laboratory Functional Guidelines for Inorganic Data Review (EPA, 1994).

- Organic analysis RPD criteria is established by the laboratory to evaluate precision for MSD and LCSD analyses.

The control limits are evaluated at the laboratory on a quarterly basis by monitoring the historical data and performance for each method. No review criteria for organic field duplicate RPD comparability have been established; therefore, the laboratory MSD RPD criteria is applied for precision evaluation of field duplicates.

Precision values for organic and inorganic analysis that are within the established control criteria indicate that analytical results for associated samples are valid. Laboratory duplicate RPD values that are outside the criteria for organic analysis do not necessarily result in the qualification of analytical data. It is only one factor in making an overall judgment about the quality of the reported analytical results. Inorganic laboratory duplicate RPD values outside the established control criteria do result in the qualification of associated analytical results as estimated. Field duplicate RPD values that are 
outside the criteria for organic and inorganic analyses do not result in the qualification of analytical data. Out of control RPD values do not necessarily indicate that the data is not useful for the purpose intended; however, it is an indication that data precision should be considered for the overall assessment of the data quality and potential impact on data application in meeting project objectives. Method-specific precision as RPD is determined by taking the number of measurements within criteria, dividing that by the number of measurements analyzed, and multiplying by 100 .

For the purpose of determining data precision of sample analyses for CAU 516, all water and soil samples, including field QC samples (e.g., trip blanks, equipment rinsate samples, field blanks) were evaluated and incorporated into the precision calculation.

Precision for the measurement of target compounds or analytes collected at CAU 516 was determined for RCRA metals, aluminum, beryllium, SVOCs, VOCs, PCBs, pesticides, TPH-DRO, and TPH-GROs. Table B.1-1 provides the field and laboratory duplicate precision analysis results.

Inorganic laboratory duplicate RPD values outside the established control criteria result in estimation for that measurement of all associated samples in the SDG. For example, if an LD had a RPD value for lead outside the established control criteria, lead results for all of the samples in that SDG would be qualified as estimated.

Out of control RPD values do not necessarily indicate that the data is not useful for the purpose intended. It does indicate that precision should be considered for the overall assessment of the data quality and impact to the application of associated data to meeting the project's objectives.

\section{B.1.1.2 Precision for Radiochemical Analysis}

The precision of radiochemical measurements is evaluated by measuring two aliquots of a sample and comparing the results. An LD is measured with every batch of samples analyzed by the laboratory. Field duplicate data are available when two aliquots of a sample are submitted to the laboratory for analysis. Matrix spike duplicates, also used to evaluate precision, are performed by the laboratory upon request.

The duplicate precision is evaluated using the RPD or normalized difference. The RPD is applicable when both the sample and its duplicate have concentrations of the target radionuclide exceeding five 
Table B.1-1

Chemical Analysis Precision Measurements for CAU 516

\begin{tabular}{|c|c|c|c|c|c|c|c|c|}
\hline & \multicolumn{6}{|c|}{ ORGANICS } & \multicolumn{2}{|c|}{ INORGANICS } \\
\hline & VOCs & SVOCs & $\begin{array}{l}\text { TPH- } \\
\text { DRO }\end{array}$ & $\begin{array}{l}\text { TPH- } \\
\text { GRO }\end{array}$ & Pesticides & PCBs & Metals $^{a}$ & Mercury \\
\hline \multicolumn{9}{|c|}{ Matrix Spike Duplicate (MSD) Precision } \\
\hline $\begin{array}{l}\text { Total Number of MSD } \\
\text { Measurements }\end{array}$ & 45 & 78 & 11 & 10 & 6 & 16 & 93 & 8 \\
\hline $\begin{array}{l}\text { Total Number of RPDs } \\
\text { Within Criteria }\end{array}$ & 43 & 77 & 10 & 9 & 6 & 16 & 93 & 7 \\
\hline MSD Percent (\%) Precision & 95.56 & 98.72 & 90.91 & 90.00 & 100 & 100 & 100 & 87.50 \\
\hline \multicolumn{9}{|c|}{ Laboratory Control Sample Duplicate (LCSD) Precision } \\
\hline $\begin{array}{c}\text { Total Number of LCSD } \\
\text { Measurements }\end{array}$ & 90 & 147 & 17 & 16 & 6 & 40 & 101 & 15 \\
\hline $\begin{array}{l}\text { Total Number of RPDs } \\
\text { Within Criteria }\end{array}$ & 90 & 147 & 17 & 16 & 6 & 40 & 101 & 15 \\
\hline LCSD \% Precision & 100 & 100 & 100 & 100 & 100 & 100 & 100 & 100 \\
\hline \multicolumn{9}{|c|}{ Field Duplicate (FD) Precision } \\
\hline $\begin{array}{c}\text { Total Number of FD } \\
\text { Measurements }\end{array}$ & 345 & 356 & 6 & 5 & 25 & 42 & 41 & 5 \\
\hline $\begin{array}{c}\text { Total Number of RPDs } \\
\text { Within Criteria }\end{array}$ & 344 & 356 & 6 & 5 & 25 & 42 & 40 & 5 \\
\hline FD \% Precision & 99.71 & 100 & 100 & 100 & 100 & 100 & 97.56 & 100 \\
\hline \multicolumn{9}{|c|}{ Laboratory Sample Duplicate (Lab-Dup) Precision } \\
\hline $\begin{array}{c}\text { Total Number of Lab-Dup } \\
\text { Measurements }\end{array}$ & NA & NA & NA & NA & NA & NA & 93 & 8 \\
\hline $\begin{array}{c}\text { Total Number of RPDs } \\
\text { Within Criteria }\end{array}$ & NA & NA & NA & NA & NA & NA & 90 & 7 \\
\hline Lab-Dup \% Precision & NA & NA & NA & NA & NA & NA & 96.77 & 87.50 \\
\hline
\end{tabular}

\footnotetext{
${ }^{a}$ Aluminum, arsenic, barium, beryllium, cadmium, chromium, lead, selenium, and silver
} 
times their minimum detectable concentration. This excludes many measurements because the samples contain nondetectable or low levels of the target radionuclide. In situations where the RPD does not apply, duplicate results are evaluated using the normalized difference which is expressed by:

$$
\text { Normalized Difference }=\frac{\mathrm{S}-\mathrm{D}}{\sqrt{\left(\mathrm{TPU}_{\mathrm{S}}\right)^{2}+\left(\mathrm{TPU}_{\mathrm{D}}\right)^{2}}}
$$

Where:

$$
\begin{array}{ll}
\mathrm{S} & =\text { Sample result } \\
\mathrm{D} & =\text { Duplicate result } \\
\mathrm{TPU}_{\mathrm{S}} & =2 \mathrm{~F} \text { total propagated uncertainty of the sample } \\
\mathrm{TPU}_{\mathrm{D}} & =2 \mathrm{~F} \text { total propagated uncertainty of the duplicate } \\
\mathrm{F} & =\text { Standard deviation }
\end{array}
$$

The control limit for the normalized difference is a unitless value from -1.96 to 1.96, which represents a confidence level of 95 percent. Depending on the sample concentration, only one duplicate evaluation needs to be performed. If the sample duplicate RPD or normalized difference is outside the control limit, the field samples measured in the same analytical batch will be qualified. Samples are not qualified based on field duplicates or MSDs.

A duplicate comparison that is outside control limits does not necessarily indicate that the data is not useful for the purpose intended; however, it is an indication data precision should be considered for the overall assessment of the data quality and potential impact on data application in meeting project site characterization objectives.

For the purpose of determining data precision of sample analyses for CAU 516, all water and soil duplicates were evaluated and incorporated into Table B.1-2 through Table B.1-4.

The isotopic gamma analysis provides results for 22 radionuclides. Only two or three of these radionuclides are usually present in sufficient concentration to allow the determination of their RPDs. The duplicate data for the remaining radionuclides is compared using the normalized difference. Matrix spike duplicate samples were not analyzed by the laboratory because of the difficulty in 
Table B.1-2

Laboratory Duplicate Precision of Radioanalytes

\begin{tabular}{|c|c|c|c|c|c|c|c|}
\hline & $\begin{array}{c}\text { Gamma } \\
\text { Spectrometry }\end{array}$ & $\begin{array}{l}\text { Isotopic } \\
\text { Uranium }\end{array}$ & $\begin{array}{c}\text { Isotopic } \\
\text { Plutonium }\end{array}$ & Sr-90 & $\begin{array}{l}\text { Gross } \\
\text { Alpha }\end{array}$ & $\begin{array}{c}\text { Gross } \\
\text { Beta }\end{array}$ & Tritium \\
\hline \multicolumn{8}{|c|}{ Relative Percent Difference } \\
\hline Number Performed & 13 & 2 & 4 & 5 & 1 & 1 & 0 \\
\hline Number Within Limits & 13 & 2 & 4 & 5 & 1 & 1 & 0 \\
\hline Percent Within Limits & 100 & 100 & 100 & 100 & 100 & 100 & NA \\
\hline \multicolumn{8}{|c|}{ Normalized Difference } \\
\hline Number Performed & 405 & 7 & 33 & 6 & 3 & 3 & 4 \\
\hline Number Within Limits & 405 & 7 & 33 & 6 & 3 & 3 & 4 \\
\hline Percent Within Limits & 100 & 100 & 100 & 100 & 100 & 100 & 100 \\
\hline
\end{tabular}

$\mathrm{NA}=$ Not applicable

Table B.1-3

Matrix Spike/Matrix Spike Duplicate Precision for Radioanalytes

\begin{tabular}{|l|c|c|c||}
\hline & Tritium & Gross Alpha & Gross Beta \\
\hline \hline \multicolumn{4}{|c|}{ Relative Percent Difference } \\
\hline Number Performed & 1 & 1 & 1 \\
\hline Number Within Limits & 1 & 1 & 1 \\
\hline Percent Within Limits & 100 & 100 & 100 \\
\hline
\end{tabular}

Table B.1-4

Laboratory Field Duplicate Precision for Radioanalytes

\begin{tabular}{|l|c|c|c|}
\hline & Gamma Spectroscopy & Isotopic Plutonium & Strontium-90 \\
\hline \hline \multicolumn{5}{|c|}{ Relative Percent Difference } \\
\hline Number Performed & 4 & 2 & 0 \\
\hline Number Within Limits & 4 & 1 & 0 \\
\hline Percent Within Limits & 100 & 50 & NA \\
\hline & Normalized Difference & 2 \\
\hline Number Performed & 62 & 6 & 2 \\
\hline Number Within Limits & 62 & 6 & 100 \\
\hline Percent Within Limits & 100 & & 2 \\
\hline
\end{tabular}


preparing homogeneous spiked duplicates and the radioactive waste produced. The results of the precision tests for laboratory isotopic gamma measurements are included in Table B.1-2.

Thirty-five duplicate pairs were measured with each containing 22 radionuclides. One-hundred percent of the RPD and normalized difference comparisons were acceptable.

The isotopic uranium analysis includes the measurement of three radionuclides, two of which often occur in concentrations sufficient for RPD evaluation. As shown by the laboratory uranium precision results in Table B.1-2, 100 percent of the RPD tests and 100 percent of the normalized difference tests were within limits.

The isotopic plutonium analysis measures two radionuclides, but usually their concentrations in samples are too low to permit the evaluation of the RPD. Table B.1-2 contains the precision results for the laboratory duplicates measured with the plutonium laboratory batches.

The strontium-90 laboratory duplicate analyses are listed in Table B.1-2. One-hundred percent of the RPD and normalized difference tests were within control limits.

The gross alpha, gross beta, and tritium analyses provide one result. Only one duplicate was analyzed by these measurements. All of the precision tests, which are included in Table B.1-2, performed with these measurements were within the established control limits.

The results of the MS and MSD comparisons are included in Table B.1-3. Since all the samples contained concentrations of the target radionuclide greater than five times the MDC, the RPD comparison was used for each set. Table B.1-3 shows 100 percent of the tritium, and gross alpha and gross beta RPDs were within established criteria.

The results of the comparison of the field duplicates are provided in Table B.1-4. One plutonium normalized difference test was outside the control limits. Of the 76 precision tests performed for field duplicate samples, 75 or 99 percent were acceptable. 


\section{B.1.1.3 Precision Summary}

Overall, the precision for CAU 516 measurements were within acceptable limits. The results of the duplicate comparison of the field and LDs for chemical analyses are provided in Table B.1-1. Of the 825 precision tests performed on FDs, 823 or 99.76 percent were within control limits. Of the 800 precision tests for LDs, LCSDs, and MSDs, 790 or 99.8 percent were within control limits. More importantly, individual precision summaries for the designated analyses as shown in the individual tables were also within control limits.

The results of LDs for radiochemical analyses, including laboratory spike and matrix spike RPDs, are provided in Table B.1-2 and Table B.1-3. Of the 490 precision tests performed for LDs and MS/MSDs, 490 or 100 percent were within control limits. The results of the duplicate comparison of the FDs for radiochemical analyses are provided in Table B.1-4. Six of the precision tests performed on the FDs (4 for gamma spectroscopy and 2 for isotopic plutonium). Four of the gamma spectroscopy and one isotopic plutonium were with control limits, 100 percent and 50 percent, respectively.

In summary, precision for CAU 516 is considered to be within acceptable limits for evaluation of the resulting data, thereby achieving established DQOs for precision.

\section{B.1.2 Accuracy}

Accuracy is a measure of the closeness of an individual measurement or the average of a number of measurements to the true value. Accuracy includes a combination of random error (precision) and systematic error (bias) components that result from sampling and analytical operations.

\section{B.1.2.1 Accuracy for Chemical Analysis}

Accuracy is determined by analyzing a reference material of known pollutant concentration or by reanalyzing a sample to which a material of known concentration or amount of pollutant has been added (spiked). Accuracy is expressed as $\% \mathrm{R}$ for the purposes of evaluating the quality of data reported for CAU 516. 
Matrix spike samples are prepared by adding a known concentration of a target analyte to a specified amount of matrix sample for which an independent estimate of the target analyte concentration is available. Spiked samples are used to determine the laboratory's overall efficiency by comparing the percent recovered to the known true value. For example, a sample that is spiked with $10 \mathrm{ppm}$ of a known analyte should produce a reported result of $10 \mathrm{ppm}$ greater than the value of the sample itself. Consequently, the accuracy for this analysis would be reported as 100 percent. Matrix spike recoveries within the specified criteria for organic and inorganic analyses indicate the laboratory is operating within established controls and producing valid, quality results. Matrix spike results outside the control limits for organic analyses may not result in qualification of the data. An assessment of the entire analytical process is performed to determine the quality of the data and whether qualification is necessary.

Laboratory control samples are generated to provide accuracy of analytical methods and laboratory performance. They are prepared, extracted (as required by method), analyzed, and reported once per SDG per matrix. For organic analyses, laboratory control limits are used to evaluate the accuracy of all analyses. The control limits are evaluated at the laboratory quarterly by monitoring the historical data and performance for each method. The acceptable limits for inorganic analyses are established in the EPA Contract Laboratory Functional Guidelines for Inorganic Data Review (1994) and are method-specific. Sample results within established control ranges for organic and inorganic analyses show that the analytical method is accurate and the data provided are valid.

Surrogates (system monitoring compounds) are used to assess the method performance for each sample analyzed for organic analyses. Control limits established by the laboratory are used to evaluate the accuracy of the surrogate recoveries. Factors beyond the laboratory's control, such as sample matrix effects, can cause the measured values to be outside of the established criteria. Therefore, the entire sampling and analytical process must be evaluated when determining the quality of the analytical data provided.

Table B.1-5 identifies the number of matrix spike, laboratory control, and surrogate measurements performed for CAU 516. The table presents the total number of measurements analyzed, the number of measurements within the specified criteria, and the percent accuracy of each method. Methodspecific accuracy is determined by taking the number of measurements within criteria, dividing that 
by the total number of measurements analyzed, and multiplying by 100 . For organic analyses, each sample had surrogates analyzed; therefore, the number of surrogates is significantly greater than the number of matrix spike and laboratory control samples.

Table B.1-5

Laboratory Analysis Accuracy Measurements for CAU 516

\begin{tabular}{|c|c|c|c|c|c|c|c|c|}
\hline & \multicolumn{6}{|c|}{ ORGANICS } & \multicolumn{2}{|c|}{ INORGANICS } \\
\hline & VOCs & SVOCs & $\begin{array}{l}\text { TPH- } \\
\text { DRO }\end{array}$ & $\begin{array}{l}\text { TPH- } \\
\text { GRO }\end{array}$ & Pesticides & PCBs & Metals $^{a}$ & Mercury \\
\hline \multicolumn{9}{|c|}{ Matrix Spike (MS) Accuracy } \\
\hline $\begin{array}{l}\text { Total Number of MS } \\
\text { Measurements }\end{array}$ & 90 & 156 & 22 & 20 & 12 & 32 & 186 & 16 \\
\hline $\begin{array}{l}\text { Total Number of MS } \\
\text { Measurements Within } \\
\text { Criteria }\end{array}$ & 62 & 156 & 21 & 13 & 10 & 32 & 181 & 15 \\
\hline MS Percent (\%) Accuracy & 68.89 & 100 & 95.45 & 65.00 & 83.33 & 100 & 97.31 & 93.75 \\
\hline \multicolumn{9}{|c|}{ Laboratory Control Sample (LCS) Accuracy } \\
\hline $\begin{array}{l}\text { Total Number of LCS } \\
\text { Measurements }\end{array}$ & 180 & 294 & 34 & 33 & 12 & 80 & 202 & 30 \\
\hline $\begin{array}{l}\text { Total Number of LCS } \\
\text { Measurements Within } \\
\text { Criteria }\end{array}$ & 180 & 294 & 34 & 33 & 12 & 80 & 202 & 30 \\
\hline LCS $\%$ Accuracy & 100 & 100 & 100 & 100 & 100 & 100 & 100 & 100 \\
\hline \multicolumn{9}{|c|}{ Surrogate Accuracy } \\
\hline $\begin{array}{l}\text { Total Number of } \\
\text { Measurements Analyzed }\end{array}$ & 8280 & 7113 & 106 & 93 & 280 & 770 & NA & NA \\
\hline $\begin{array}{l}\text { Total Number of } \\
\text { Measurements Not } \\
\text { Affected by Out-of-Control } \\
\text { Surrogates }\end{array}$ & 8210 & 6894 & 105 & 93 & 256 & 665 & NA & NA \\
\hline Surrogate $\%$ Accuracy & 99.15 & 96.92 & 99.06 & 100 & 91.43 & 86.36 & NA & NA \\
\hline
\end{tabular}

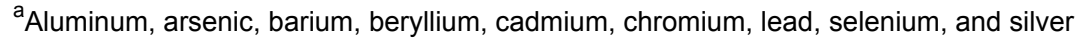

NA $=$ Not applicable

The matrix spike accuracy results for organic analyses in Table B.1-5 include the total number of matrix spike measurements per analysis and the number of matrix spike measurements within criteria. All samples for organic analyses within the associated SDG are not qualified, only the native sample to which the spike was added. Inorganic matrix spike results outside of the established control 
criteria do result in data qualified as estimated for all the samples in that batch. However, only the analyte(s) outside of control requires qualification.

Table B.1-5 includes the total number of LCS measurements per analysis and the number of LCS measurements within criteria. Laboratory control samples within the specified criteria for organic and inorganic analyses indicate the laboratory is producing valid data. Laboratory control samples outside of the established criteria result in the qualification of inorganic data and may result in the qualification of organic data. For organic analyses, an evaluation of the overall analytical process is performed to determine if data qualification is necessary. Inorganic LCS recoveries outside of established controls require data to be qualified for the individual analyte out of control. If the LCS criteria are not met, the laboratory performance and method accuracy are in question.

Surrogates reported within established control criteria indicate good laboratory method performance and the absence of matrix influences on the samples and result in quality, valid data. Table B.1-5 includes the total number of sample measurements performed for each method and the total number of sample measurements qualified for surrogate recoveries exceeding criteria. The estimated organic data in this CAU do not necessarily indicate the data are not useful. Data qualification is one factor to be considered in the overall assessment of the data quality and the impact to the project's objectives.

Accuracy for the measurement of target analytes collected at CAU 516 was determined for RCRA metals, aluminum, beryllium, SVOCs, VOCs, PCBs, pesticides, TPH-DRO, and TPH-GRO.

For the purpose of determining data accuracy of sample analysis for CAU 516, all water and soil samples including field QC samples (e.g., trip blanks, equipment rinsate samples, field blanks) were evaluated and incorporated into the accuracy calculation.

\section{B.1.2.2 Accuracy for Radiochemical Analysis}

Laboratory control samples and MS samples are used to determine the accuracy of radioanalytical measurements. The LCS is prepared by adding a known concentration of the radionuclide being measured to a sample that does not contain radioactivity (i.e., distilled water). This sample is analyzed with the field samples using the same sample preparation, reagents, and analytical methods 
employed for the samples. One LCS is prepared with each batch of samples for analysis by a specific measurement.

Matrix spike samples are prepared by adding a known concentration of a target radionuclide to a specified field sample with a measured concentration. The MS samples are analyzed to determine if the measurement accuracy is affected by the sample matrix. The MS samples are analyzed with sample batches when requested.

For CAU 516, LCS samples were analyzed for the isotopic gamma spectroscopy, uranium, isotopic plutonium, strontium-90, tritium, gross alpha, and beta analyses. Matrix spike samples were analyzed for the gross alpha, gross beta, and tritium analyses.

The accuracy of the LCS determination is expressed as a percent recovery by the following:

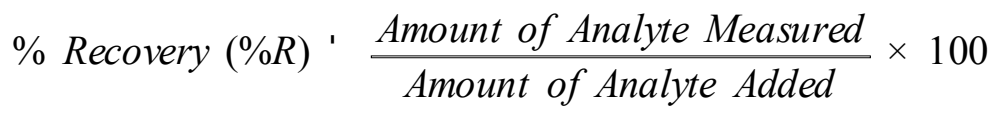

The accuracy of the MS determination is expressed as a percent recovery by the following:

$$
\% \text { Recovery }(\% R)^{\prime} \frac{\text { MS Result \& Sample Result }}{\text { Amount of Analyte Added }} \times 100
$$

If the LCS recoveries are outside acceptable control limits, qualifiers will be added to the field samples analyzed with the LCS. However, MS results outside this control range may not result in qualification of the data. An assessment of the entire analytical process including the sample matrix is performed to determine if qualification is necessary.

Table B.1-6 and Table B.1-7 identify the number of laboratory control and matrix spike samples, including soil and water matrices measured for each radiochemical measurement for CAU 516. The percent accuracy for the procedure is determined as the number of LCS or MS samples analyzed within the control limits, divided by the total number analyzed, and multiplied by 100 . 
Table B.1-6

Radioanalyte Laboratory Control Sample Accuracy

\begin{tabular}{||l|c|c|c|c|c|c|c||}
\hline & $\begin{array}{c}\text { Gamma } \\
\text { Spectrometry }\end{array}$ & $\begin{array}{c}\text { Isotopic } \\
\text { Uranium }\end{array}$ & $\begin{array}{c}\text { Isotopic } \\
\text { Plutonium }\end{array}$ & Strontium-90 & $\begin{array}{c}\text { Gross } \\
\text { Alpha }\end{array}$ & $\begin{array}{c}\text { Gross } \\
\text { Beta }\end{array}$ & Tritium \\
\hline \hline Total Number & 76 & 6 & 18 & 15 & 4 & 4 & 4 \\
\hline $\begin{array}{l}\text { Total Number } \\
\text { Within Criteria }\end{array}$ & 76 & 6 & 18 & 15 & 4 & 4 & 4 \\
\hline $\begin{array}{l}\text { Laboratory Control } \\
\text { Sample Percent } \\
\text { Accuracy }\end{array}$ & 100 & 100 & 100 & 100 & 100 & 100 & 100 \\
\hline
\end{tabular}

Table B.1-7

Radioanalyte Matrix Spike Accuracy

\begin{tabular}{|l|c|c|c|}
\hline & Gross Alpha & Gross Beta & Tritium \\
\hline \hline Total Number & 4 & 4 & 4 \\
\hline Total Number Within Criteria & 2 & 4 & 2 \\
\hline Matrix Spike Percent Accuracy & 50 & 100 & 50 \\
\hline
\end{tabular}

Each isotopic gamma LCS contains four radionuclides, each of which has a percent recovery determined. As indicated in Table B.1-6, 100 percent of the gamma LCS measurements were within control limits.

Three uranium radionuclides are added to the isotopic uranium LCS, but the uranium-235 concentration is usually too low to allow evaluation. The isotopic plutonium, strontium-90, gross beta, and tritium LCS and MS samples contain one added radionuclide.

Laboratory control samples within the specified criteria for radiological analyses indicate the laboratory is producing valid data. If the LCS criteria are not met, the laboratory performance and method accuracy are in question. Radiological LCS recoveries outside of established controls require data to be qualified for the individual radionuclide out of control. Since LCS recoveries were 100 percent for all analyses, no field samples were qualified based on LCS performance.

Two gross alpha and two tritium MS recoveries were outside of control limits, but no samples were qualified, because measuring a MS by gross alpha has inherent problems. The two high tritium MS 
recoveries could be due to matrix interference or heterogeneity of the water or tritium content of the sludge sample.

\section{B.1.2.3 Accuracy Summary}

Overall, accuracy for CAU 516 was within acceptable limits. Surrogate recoveries, which gauge the accuracy of individual sample results for specified chemical analyses, were within acceptable accuracy ranges ( 86 percent or better). The percentage of acceptable LCS recoveries was 100 percent for all chemical analyses indicating that the failed TPH-DRO and VOC matrix spike recoveries were likely the result of matrix interferences and not an analytical problem. The likely reason for the lower percentage of TPH-GRO results within acceptable range was due to the high concentrations of TPH-GRO in some of the samples. Higher TPH contaminant concentration often masks the recovery percentage for spiked samples. Radioanalytical LCS recoveries were 100 percent.

Two gross alpha and two tritium MS recoveries were outside of control limits, but no samples were qualified, because measuring a MS by gross alpha has inherent problems. The two high tritium MS recoveries could be due to matrix interference or heterogeneity of the water or tritium content of the sludge sample.

In summary, accuracy results for CAU 516 are considered acceptable and meet DQO requirements.

\section{B.1.3 Completeness}

Completeness is defined as the acquisition of sufficient data of the appropriate quality to satisfy DQO decisions. A measure of completeness is the amount of data that are judged to be valid. Percent completeness for sample analyses was determined by dividing the total number of samples analyzed (per method) by the total number of samples sent to the laboratory (per method) and multiplied by 100. Percent completeness for measurement usability (not rejected) was determined by dividing the total number of nonrejected measurements by the total number measurements (per method) and multiplied by 100. All measurements for completeness include reanalyses. Table B.1-8 and Table B.1-9 contain results of completeness per analytical method. 
Table B.1-8

Chemical Completeness for CAU 516

\begin{tabular}{|c|c|c|c|c|c|c|c|c|}
\hline \multirow{2}{*}{ Completeness Parameters } & \multicolumn{6}{|c|}{ ORGANICS } & \multicolumn{2}{|c|}{ INORGANICS } \\
\hline & VOCs & SVOCs & $\begin{array}{l}\text { TPH- } \\
\text { DRO }\end{array}$ & $\begin{array}{l}\text { TPH- } \\
\text { GRO }\end{array}$ & Pesticides & PCBs & Metals $^{a}$ & Mercury \\
\hline \multicolumn{9}{|c|}{ Sample Analysis Completeness } \\
\hline $\begin{array}{l}\text { Total Samples Sent to } \\
\text { Laboratory }\end{array}$ & 116 & 97 & 106 & 93 & 7 & 110 & 99 & 99 \\
\hline Total Samples Analyzed & 116 & 97 & 106 & 93 & 7 & 110 & 99 & 99 \\
\hline Percent Completeness & 100 & 100 & 100 & 100 & 100 & 100 & 100 & 100 \\
\hline \multicolumn{9}{|c|}{ Measurement Usability Completeness } \\
\hline Total Measurements $^{b}$ & 8280 & 7113 & 106 & 93 & 280 & 770 & 830 & 99 \\
\hline $\begin{array}{l}\text { Total Measurements } \\
\text { Rejected - Field }\end{array}$ & 0 & 0 & 0 & 0 & 0 & 0 & 0 & 0 \\
\hline $\begin{array}{l}\text { Total Measurements } \\
\text { Rejected - Lab/Matrix }\end{array}$ & 68 & 64 & 0 & 0 & 0 & 7 & 0 & 0 \\
\hline Percent Completeness & 99.18 & 99.10 & 100 & 100 & 100 & 99.09 & 100 & 100 \\
\hline
\end{tabular}

${ }_{b}^{a}$ Aluminum, arsenic, barium, beryllium, cadmium, chromium, lead, selenium, and silver

${ }^{\mathrm{b}}$ Measurements include re-analyses

Table B.1-9

Radiological Completeness for CAU 516

\begin{tabular}{|c|c|c|c|c|c|c|}
\hline \multirow{2}{*}{ Completeness Parameters } & \multicolumn{6}{|c|}{ Radiological Analytical Methods } \\
\hline & EPA906.0 & ISOU & SM7110 & SR7500 & HASL300 & UGTAISOPU \\
\hline \multicolumn{7}{|c|}{ Sample Analysis Completeness } \\
\hline Total Samples Sent to Laboratory & 9 & 10 & 9 & 62 & 71 & 95 \\
\hline Total Samples Analyzed & 9 & 10 & 9 & 62 & 71 & 95 \\
\hline Percent Completeness & 100 & 100 & 100 & 100 & 100 & 100 \\
\hline \multicolumn{7}{|c|}{ Measurement Usability Completeness } \\
\hline Total Measurements $^{a}$ & 9 & 30 & 18 & 62 & 1562 & 190 \\
\hline $\begin{array}{l}\text { Total Measurements Rejected - } \\
\text { Field }\end{array}$ & 0 & 0 & 0 & 0 & 0 & 0 \\
\hline $\begin{array}{l}\text { Total Measurements Rejected - } \\
\text { Lab/Matrix }\end{array}$ & 0 & 0 & 0 & 0 & 2 & 0 \\
\hline Percent Completeness & 100 & 100 & 100 & 100 & 99.95 & 100 \\
\hline
\end{tabular}

${ }^{\mathrm{a}}$ Measurements include re-analyses 
Completeness for chemical and radioanalytical analyses was 99 percent or better. Rejected data were thoroughly reviewed and questions concerning these data have been addressed. In accordance with the CAU 516 CAIP, 80 percent of CAS-specific noncritical samples and analyses had valid results. One-hundred percent of CAS-specific critical parameters had valid results with the exception of CAS 03-59-02, which had hydroquinone results rejected for samples 516B028, 516B031, 516B032, and 516B033. The rejected data are not considered to have adversely impacted the decision-making process. Although the completeness was less than planned, the data are complete to the degree that they support the decision made based on the DQO and the nature and extent of detected contamination.

The specified sampling locations were used as planned and all samples were collected as specified in the CAU 516 CAIP (NNSA/NSO, 2003). In accordance with the CAU 516 CAIP (Table 6-1), 100 percent of requested analyses were conducted.

Rejected data affecting completeness are presented and discussed on a CAS-by-CAS basis in Section B.1.4.

\section{B.1.3.1 Completeness Summary}

As shown in Table B.1-8 and Table B.1-9, completeness objectives for this CAU have been achieved with the exception of hydroquinone. Completeness for chemical analyses were 99 percent. Completeness for radiochemical analyses was 100 percent. Rejected data have been thoroughly reviewed and questions concerning these data have been addressed on a CAS-by-CAS basis. Rejected data have been determined to have no affect on closure decisions for this CAU. Overall, measurements and sampling completeness criteria have been satisfied for the CAU 516 CAI.

\section{B.1.4 Rejected Data}

\section{Rejected Data for CAS 03-59-01, Bldg 3C-36 Septic System}

Table B.1-10 contains the rejected results per analyte for CAS 03-59-01. Acetone results for several samples in this CAS, including the trip blank, were rejected due to the generation of a relative response factor of less than 0.05 in both the initial and continuing calibrations. Acetone was not detected greater than the contract-required detection limit (CRDL), which is orders of magnitude less 
Table B.1-10

CAU 516 Rejected Data for CAS 03-59-01

\begin{tabular}{|c|c|c|c|}
\hline Sample Location & Sample Number & Parameter & Matrix \\
\hline \multirow{2}{*}{$\mathrm{A} 01$} & 516A001 & Acetone & Soil \\
\hline & 516A002 & Acetone & Soil \\
\hline \multirow{2}{*}{$\mathrm{A} 02$} & 516A003 & Acetone & Soil \\
\hline & $516 \mathrm{~A} 018$ & Acetone & Soil \\
\hline A03 & $516 \mathrm{~A} 016$ & Acetone & Soil \\
\hline $\mathrm{A} 04$ & $516 \mathrm{~A} 015$ & Acetone & Soil \\
\hline $\mathrm{A} 07$ & 516A008 & Acetone & Soil \\
\hline A09 & $516 \mathrm{~A} 010$ & Acetone & Soil \\
\hline A10 & 516A011 & Acetone & Soil \\
\hline A12 & $516 \mathrm{~A} 013$ & Acetone & Soil \\
\hline \multirow{26}{*}{ Septic tank effluent chamber } & \multirow{13}{*}{ 516A501S } & Bis(2-ethylhexyl)phthalate & Solid \\
\hline & & Di-n-octyl phthalate & Solid \\
\hline & & Pyrene & Solid \\
\hline & & Benzo(g,h,i)perylene & Solid \\
\hline & & Indeno(1,2,3-cd)pyrene & Solid \\
\hline & & Benzo(b)fluoranthene & Solid \\
\hline & & Benzo(k)fluoranthene & Solid \\
\hline & & Chrysene & Solid \\
\hline & & Benzo(a)pyrene & Solid \\
\hline & & Dibenzo(a,h)anthracene & Solid \\
\hline & & Benzo(a)anthracene & Solid \\
\hline & & Butyl benzyl phthalate & Solid \\
\hline & & 3,3'-dichlorobenzidine & Solid \\
\hline & \multirow{13}{*}{ 516A502SRR1 } & Chrysene & Solid \\
\hline & & Pyrene & Solid \\
\hline & & Benzo(a)anthracene & Solid \\
\hline & & 3,3'-dichlorobenzidine & Solid \\
\hline & & Butyl benzyl phthalate & Solid \\
\hline & & Bis(2-ethylhexyl)phthalate & Solid \\
\hline & & Dibenzo(a,h)anthracene & Solid \\
\hline & & Indeno(1,2,3-cd)pyrene & Solid \\
\hline & & Benzo(k)fluoranthene & Solid \\
\hline & & Benzo(g,h,i)perylene & Solid \\
\hline & & Benzo(a)pyrene & Solid \\
\hline & & Di-n-octyl phthalate & Solid \\
\hline & & Benzo(b)fluoranthene & Solid \\
\hline
\end{tabular}


than the PRG; therefore, there is no adverse effect on the decision process. With the exception of 1,4-dichlorobenzene, SVOC target analytes detected in samples collected from the septic tank were rejected due to a very low response for their associated internal standard due to matrix interferences. Owing to sample matrix interferences, the sample was diluted; however, the remaining sample matrix effect was still sufficient to mask the response of the internal standard.

\section{Rejected Data for CAS 03-59-02, Bldg 3C-45 Septic System}

Table B.1-11 contains the rejected results per SVOC and VOC analyte for CAS 03-59-02. Acetone results for soil samples collected at this CAS were rejected due to the generation of a relative response factor of less than 0.05 in both the initial and continuing calibrations. Many of the SVOC target analytes detected in samples collected from the septic tank were rejected due to a very low response for their associated internal standard. Sample matrix interferences also resulted in a low response for the internal standard associated with these target analytes.

Hydroquinone analysis was required for samples collected from the photoprocessing dry well at CAS 03-59-02; however, all the hydroquinone analytical results were rejected. Hydroquinone results for soil samples were rejected due to the generation of a relative response factor of less than 0.05 in both the initial and continuing calibrations. Hydroquinone was not detected greater than the CRDL, which is orders of magnitude less than the PRG. Other SVOCs were detected in the soil at the photoprocessing dry well at concentrations less than the CRDL. The rejected data listed in Table B.1-11 do not adversely affect the decision-making process for selecting the appropriate corrective action for the soil or for selecting the appropriate disposal method for the septic tank contents at CAS 03-59-02.

\section{Rejected Data For CAS 06-51-01, Sump and Piping}

Table B.1-12 contains the rejected results by analyte for CAS 06-51-01. Acetone results for several samples in this CAS were rejected due to the generation of a relative response factor of less than 0.05 in both the initial and continuing calibrations. The presence of acetone in samples is commonly the result of cross contamination during analysis at the off-site laboratory rather than an environmental $\mathrm{COC}$; therefore, the rejected data for acetone has no impact on closure decisions. 
Table B.1-11

CAU 516 Rejected Data for CAS 03-59-02

(Page 1 of 2)

\begin{tabular}{|c|c|c|c|}
\hline Sample Location & Sample Number & Parameter & Sample Matrix \\
\hline B01 & 516B001 & Acetone & Soil \\
\hline \multirow{2}{*}{ B02 } & 516B003 & Acetone & Soil \\
\hline & 516B004 & Acetone & Soil \\
\hline \multirow{2}{*}{ B03 } & 516B005 & Acetone & Soil \\
\hline & 516B006 & Acetone & Soil \\
\hline \multirow{2}{*}{ B04 } & 516B007 & Acetone & Soil \\
\hline & 516B008 & Acetone & Soil \\
\hline \multirow{2}{*}{ B05 } & 516B009 & Acetone & Soil \\
\hline & 516B010 & Acetone & Soil \\
\hline \multirow{3}{*}{ B06 } & 516B011 & Acetone & Soil \\
\hline & 516B012 & Acetone & Soil \\
\hline & 516B013 & Acetone & Soil \\
\hline B07 & 516B014 & Acetone & Soil \\
\hline \multirow{2}{*}{ B08 } & 516B015 & Acetone & Soil \\
\hline & 516B016 & Acetone & Soil \\
\hline B09 & 516B017 & Acetone & Soil \\
\hline B10 & 516B018 & Acetone & Soil \\
\hline \multirow{2}{*}{ B11 } & 516B019 & Acetone & Soil \\
\hline & 516B020 & Acetone & Soil \\
\hline $\mathrm{B} 12$ & 516B021 & Acetone & Soil \\
\hline B13 & 516B022 & Acetone & Soil \\
\hline B14 & 516B023 & Acetone & Soil \\
\hline B15 & 516B024 & Acetone & Soil \\
\hline B16 & 516B025 & Acetone & Soil \\
\hline \multirow{2}{*}{ B17 } & $516 \mathrm{~B} 027$ & Acetone & Soil \\
\hline & 516B028 & Hydroquinone & Soil \\
\hline B18 & 516B029 & Acetone & Soil \\
\hline \multirow{3}{*}{ B19 } & 516B031 & Hydroquinone & Soil \\
\hline & 516B032 & Hydroquinone & Soil \\
\hline & 516B033 & Hydroquinone & Soil \\
\hline
\end{tabular}


Table B.1-11

CAU 516 Rejected Data for CAS 03-59-02

(Page 2 of 2)

\begin{tabular}{|c|c|c|c|}
\hline Sample Location & Sample Number & Parameter & Sample Matrix \\
\hline \multirow{26}{*}{ Septic Tank Effluent Chamber } & \multirow{6}{*}{ 516B501L } & Benzo(g,h,i)perylene & Liquid \\
\hline & & Indeno(1,2,3-cd)pyrene & Liquid \\
\hline & & Benzo(b)fluoranthene & Liquid \\
\hline & & Benzo(k)fluoranthene & Liquid \\
\hline & & Benzo(a)pyrene & Liquid \\
\hline & & Dibenzo(a,h)anthracene & Liquid \\
\hline & \multirow{12}{*}{ 516B501S } & Bis(2-ethylhexyl)phthalate & Solid \\
\hline & & Di-n-octyl phthalate & Solid \\
\hline & & Benzo(g,h,i)perylene & Solid \\
\hline & & Indeno(1,2,3-cd)pyrene & Solid \\
\hline & & Benzo(b)fluoranthene & Solid \\
\hline & & Benzo(k)fluoranthene & Solid \\
\hline & & Chrysene & Solid \\
\hline & & Benzo(a)pyrene & Solid \\
\hline & & Dibenzo(a,h)anthracene & Solid \\
\hline & & Benzo(a)anthracene & Solid \\
\hline & & Butyl benzyl phthalate & Solid \\
\hline & & 3,3'-dichlorobenzidine & Solid \\
\hline & 516B501RR1 & Acetone & Liquid \\
\hline & \multirow{7}{*}{ 516B503 } & Aroclor 1016 & Liquid \\
\hline & & Aroclor 1221 & Liquid \\
\hline & & Aroclor 1232 & Liquid \\
\hline & & Aroclor 1242 & Liquid \\
\hline & & Aroclor 1248 & Liquid \\
\hline & & Aroclor 1254 & Liquid \\
\hline & & Aroclor 1260 & Liquid \\
\hline \multirow{6}{*}{ Septic Tank Influent Chamber } & \multirow{4}{*}{ 516B502S } & Di-n-octyl phthalate & Solid \\
\hline & & Dibenzo(a,h)anthracene & Solid \\
\hline & & Benzo(a)anthracene & Solid \\
\hline & & 3,3'-dichlorobenzidine & Solid \\
\hline & 516B502RR1 & Acetone & Liquid \\
\hline & 516B502RR2 & Acetone & Liquid \\
\hline
\end{tabular}


Table B.1-12

CAU 516 Rejected Data for CAS 06-51-01

\begin{tabular}{|c|c|c|c|}
\hline Sample Location & Sample Number & Parameter & Sample matrix \\
\hline \multirow{2}{*}{$\mathrm{C} 01$} & $516 C 001$ & Acetone & Soil \\
\hline & $516 \mathrm{C} 002$ & Acetone & Soil \\
\hline \multirow{2}{*}{$\mathrm{C02}$} & $516 \mathrm{C003}$ & Acetone & Soil \\
\hline & $516 C 008$ & Acetone & Soil \\
\hline $\mathrm{C} 03$ & $516 \mathrm{C} 004$ & Acetone & Soil \\
\hline $\mathrm{CO} 4$ & $516 C 005$ & Acetone & Soil \\
\hline $\mathrm{C} 06$ & $516 \mathrm{C} 012$ & Acetone & Soil \\
\hline \multirow{2}{*}{$\mathrm{C} 07$} & $516 \mathrm{C009}$ & Acetone & Soil \\
\hline & $516 \mathrm{C} 010$ & Acetone & Soil \\
\hline $\mathrm{C} 08$ & $516 C 011$ & Acetone & Soil \\
\hline
\end{tabular}

\section{Rejected Data for CAS 06-51-03, Clean Out Box and Piping}

Table B.1-13 contains the rejected results by analyte for CAS 06-51-03. Acetone results for several samples in this CAS were rejected due to the generation of a relative response factor of less than 0.05 in both the initial and continuing calibrations. The presence of acetone in samples is commonly the result of cross contamination during analysis at the off-site laboratory rather than an environmental $\mathrm{COC}$; therefore, the rejected data for acetone has no impact on closure decisions. In addition, several SVOC target analyte results were rejected due to a very low response for their associated internal standard. Sample matrix interferences resulted in a low response for the internal standard associated with these target analytes.

\section{Rejected Data for CAS 22-19-04, Vehicle Decontamination Area}

Table B.1-14 contains the rejected results per analyte for CAS 22-19-04. Acetone results for several samples in this CAS were rejected due to the generation of a relative response factor of less than 0.05 in both the initial and continuing calibrations. The presence of acetone in samples is commonly the result of cross contamination during analysis at the off-site laboratory rather than an environmental $\mathrm{COC}$; therefore, the rejected data for acetone has no impact on closure decisions. In addition, all 
Table B.1-13

CAU 516 Rejected Data for CAS 06-51-03

\begin{tabular}{|c|c|c|c|}
\hline Sample Location & Sample Number & Parameter & Sample Matrix \\
\hline D01 & $516 \mathrm{D} 001$ & Acetone & Soil \\
\hline D02 & $516 \mathrm{D} 002$ & Acetone & Soil \\
\hline D03 & $516 \mathrm{D} 003$ & Acetone & Soil \\
\hline D04 & $516 \mathrm{D} 004$ & Acetone & Soil \\
\hline D05 & $516 \mathrm{D} 007$ & Acetone & Soil \\
\hline \multirow{6}{*}{ D06 } & \multirow{6}{*}{ 516D008 } & Benzo(g,h,i)perylene & Soil \\
\hline & & Indeno(1,2,3-cd)pyrene & Soil \\
\hline & & Benzo(b)fluoranthene & Soil \\
\hline & & Benzo(k)fluoranthene & Soil \\
\hline & & Benzo(a)pyrene & Soil \\
\hline & & Dibenzo(a,h)anthracene & Soil \\
\hline
\end{tabular}

Table B.1-14

CAU 516 Rejected Data for CAS 22-19-04

\begin{tabular}{|c|c|c|c|}
\hline Sample Location & Sample Number & Analyte & Sample Matrix \\
\hline E01 & 516E002 & Acetone & Soil \\
\hline E03 & 516E003 & Acetone & Soil \\
\hline E04 & 516E004 & Acetone & Soil \\
\hline \multirow{6}{*}{ E05 } & \multirow{6}{*}{ 516E005 } & Benzo(g,h,i)perylene & Soil \\
\hline & & Indeno(1,2,3-cd)pyrene & Soil \\
\hline & & Benzo(b)fluoranthene & Soil \\
\hline & & Benzo(k)fluoranthene & Soil \\
\hline & & Benzo(a)pyrene & Soil \\
\hline & & Dibenzo(a,h)anthracene & Soil \\
\hline
\end{tabular}


SVOC target analyte results were rejected due to a very low response for their associated internal standard. Sample matrix interferences also resulted in a low response for the internal standard associated with these target analytes. The rejected results for this CAS do not contradict the closure decision for this CAS.

\section{B.1.5 Representativeness}

The DQO process as identified in Appendix A of the CAIP was used to address sampling and analytical requirements for CAU 516. During this process, appropriate locations were selected that ensured the samples collected would be representative of the area being evaluated. In many cases, both a biased and random sampling approach was proposed in order to provide the most conservative evaluation possible. Biased sampling in this case was performed to ensure sampling of suspected or known contamination. This was performed on a CAS-by-CAS basis. In addition, analytical requirements were specified in order to ensure appropriate methods were selected for COPCs. This was performed to address the concerns of all stakeholders and project personnel. The DQO approach was based upon process knowledge gained during the preliminary assessment. Samples were collected and analyzed as planned with the completeness issues discussed above. In addition, QC blanks were used as a way of measuring outside factors that could impact sample results. No data were qualified due to QC blanks. Therefore, the analytical data acquired during the CAU 516 corrective action investigation are considered representative of site contamination.

\section{B.1.6 Comparability}

Field sampling, as described in the CAU 516 CAIP (NNSA/NSO, 2003), was performed and documented in accordance with approved procedures that are comparable to standard industry practices. The DOE-approved analytical methods and procedures were used to analyze, report, and validate the data. These are comparable to other methods used not only in industry and government practices, but most importantly are comparable to other investigations conducted for the NTS. Therefore, datasets within this project are considered comparable to other datasets generated using these same standardized DOE procedures, thereby meeting DQO requirements.

Approved standard field and analytical methods also ensured that data were appropriate for comparison to the investigation action levels specified in the CAIP. 


\section{B.1.7 Sensitivity}

The evaluation criterion for sensitivity has been achieved. The MRLs and MDCs for each identified organic, inorganic, or radioactive contaminant are less than or equal to their corresponding PALs or MDCs.

\section{B.1.8 Reconciliation of Conceptual Site Model(s) to the Data}

This section provides a reconciliation of the data collected and analyzed during this investigation with the conceptual site models established in the DQO process.

\section{B.1.8.1 Conceptual Site Models}

Two CSMs were developed for the CAU 516 CASs as presented in the CAIP (NNSA/NSO, 2003). The CSMs were based on historical information and process knowledge. Each CSM is discussed in the following sections. In some instances, CSMs apply to several of the CAU 516 CASs.

\section{B.1.8.1.1 Septic System Conceptual Site Model}

This section describes CSM elements for the CAU 516 CASs with a septic system (i.e., septic tank, distribution box, and septic system piping) as a component. The following CASs included in this category are CASs 03-59-01, 03-59-02, 06-51-01, and 06-51-03.

The primary source of contamination for the CAS listed above is associated with potential releases from the sources, septic system piping, the septic tank, and distribution box.

Releases at CAS 03-59-01 were through one floor drain discharging effluent into a pipe that lead to a septic tank, then to a distribution box for dispersion into the leachfield through perforated distribution lines. Releases at CAS 03-59-02 were through a discharge pipe exiting the south side of the building. Another release at this CAS was through a discharge pipe exiting to the west side and leading to a dry well. Also, a release from the mobile photoprocessing trailers through the discharge pipe to a separate dry well located north of the leachfield. Release at CAS 06-51-01 was through a 4-in. VCP running north and exiting into the sump. Release at CAS 06-51-03 was through a 6-in. diameter cast-iron pipe entering the west side of the clean-out box. The pipe served as an access point to the discharge that exited in the sump (CAS 06-51-01). 
The affected media are subsurface soils beneath the base of the septic tank, distribution box, and associated piping. The mechanisms for this type of contamination include both designed (e.g., septic system, distribution box) and accidental (e.g., valve breaches, piping leaks) releases. This model assumed that any contamination would be concentrated beneath the outlet and inlet pipe ends and the base of the septic tanks, beneath the outlet end pipe and the base of the distribution boxes, and beneath any breaches in the associated piping. The extent of underlying soil impact is assumed to be minimal based on the ambient and environmental conditions at the NTS such as low precipitation, high evapotranspiration, and the limited mobility of COPCs. The CSM and system configurations were consistent with those provided in the CAIP (NNSA/NSO, 2003).

\section{B.1.8.1.2 Leachfield Conceptual Site Model}

This section describes CSM elements for the CAU 516 CASs with a leachfield as a component. The CASs included in this category are CASs 03-59-01 and 03-59-02. The primary source of potential contamination for the CASs listed above is associated with the dispersion of effluent throughout the leachfield by way of perforated distribution pipes.

Releases at CAS 03-59-01 were through one drain exiting into a discharge pipe eventually exiting into the leachfield. Releases at CAS 03-59-02 were through a discharge pipe exiting the south side of the building into the leachfield.

The affected medium is soil beneath the leachrock/native soil interface impacted by subsurface release of effluent. The mechanisms for this type of release include both designed (e.g., surface discharge point) and accidental (e.g., distribution pipe breaches) releases. This CSM assumed that any contamination would migrate away from the release point, primarily downward, and to a lesser degree horizontally. The highest concentration of contaminants would be located in soil beneath the leachrock/native soil interface, and would decrease with distance, both horizontally and vertically. The lateral and vertical extent of contamination at these sites is assumed to be minimal based on ambient and environmental conditions such as low precipitation, high evapotranspiration, significant depth to groundwater, and the mobility of COPCs. The CSM and system configurations were consistent with those provided in the CAIP (NNSA/NSO, 2003). 


\section{B.1.8.1.3 Clean-Out Box Conceptual Site Model}

This section describes CSM elements for the CAU 516 CASs with a clean-out box as a component; CAS 06-51-03 is included in this category.

The primary source of contamination for the CAS listed above is associated with the discharge of effluent through piping running through a clean-out box.

Release at CAS 06-51-03 was through a single drain from Building 660 into a discharge pipe leading to the sump (CAS 06-59-01). The clean-out box provides a single-point access to this discharge pipe.

The affected medium is the subsurface soil beneath the base of the clean-out box. The mechanisms for this type of contamination include both designed (e.g., clean-out box) and accidental (e.g., valve breaches, piping leaks, direct discharge) releases. This model assumed that any contamination would be concentrated in the soil beneath the base of the clean-out box and would decrease with distance, both horizontally and vertically. The lateral and vertical extent of contamination at these sites is assumed to be minimal based on ambient and environmental conditions such as low precipitation, high evapotranspiration, and significant depth to groundwater. The CSM and system configurations were consistent with those provided in the CAIP (NNSA/NSO, 2003).

The extent of underlying soil impact is expected to be variable and is dependent upon the volume of effluent released, system design, geologic conditions, nature of COPCs, and other factors. The CSM and system configurations were consistent with those provided in the CAIP (NNSA/NSO, 2003).

\section{B.1.8.1.4 Sump Conceptual Site Model}

This section describes CSM elements for the CAU 516 CASs designated as sumps; CASs 06-51-01 and 22-19-04 are included in this category.

The contamination at CAS 06-51-01 is associated with the potential release of radionuclides from both the slaughtering of radiologically contaminated animals used in animal studies and the on-site storage of radiologically contaminated animal feed. The release at CAS 22-19-04 was a direct surface discharge onto an unlined decontamination pad flowing into a trench and then into an unlined 
sump. Additional potential contamination at both these CASs include VOCs and SVOCs released during the use of high-pressure water and detergents used for decontamination.

The primary release pathway for potential contamination for these two CASs is associated with the migration of effluent to the surface and subsurface soil surrounding and/or below the sumps. Therefore, the general CSM included soil potentially impacted by a release of effluent during the decontamination process. The mechanisms for this type of release include both designed (e.g., surface discharge) and accidental (e.g., piping leaks) releases.

This model assumed that any contamination would be concentrated in the soil located beneath the sumps. The lateral and vertical extent of contamination at these sites is assumed to be minimal based on the environmental conditions such as low precipitation, high evapotranspiration, and significant depth to groundwater. The CSM and system configurations were consistent with those provided in the CAIP (NNSA/NSO, 2003).

\section{B.1.8.1.5 Dry Well Conceptual Site Model}

This section describes CSM elements for the CAU 516 CAS with a dry well as a component; CAS 03-59-02 is included in this category.

The primary source of potential contamination for the two dry wells at CAS 03-59-02 is a single-point source for each dry well.

The release into the LANL dry well was through a floor drain in Building 3C-45 discharging directly into the dry well. The photoprocessing dry well was used for the disposal of photoprocessing chemicals that were discharged directly into a single discharge pipe leading to the dry well.

The affected medium is the soil beneath the base of the dry wells. The mechanisms for this type of release include both designed (e.g., dry wells) and accidental (e.g., piping leaks) releases. This model assumed that the highest concentration of contaminants are at the base of the dry wells. The contamination should decrease with distance vertically and horizontally (to a greater extent). The lateral and vertical extent of contamination at these sites is expected to be minimal based on ambient and environmental conditions such as low precipitation, high evapotranspiration, and significant depth to groundwater. The concentrations of silver were consistent and did not show a decrease in the 
interval below the base of the dry well. However, based on the analytical results for other COPCs, the CSM and system configurations were consistent with those provided in the CAIP (NNSA/NSO, 2003). There is no driver requiring deeper sampling, if a COPC concentration does not exceed the PAL.

\section{B.1.8.2 Contaminant Nature and Extent}

The presence of contamination was identified by sample results showing COPC concentrations in soil exceeding the PALs identified in the CAIP; thereby, defining COCs at the CASs. In general, soil sample results demonstrated that the vertical and lateral extent of COCs was limited to the physical boundaries of the CSMs defined in the CAIP (NNSA/NSO, 2003). Field screening was conducted and samples were collected at locations to bound contaminated areas with results below action levels. This confirmed that the extent of contamination was limited to regions defined by the CAS-specific CSMs. The CAS-specific investigation findings, analytical results, and descriptions of site conditions are presented in Appendix A.

\section{B.1.9 Conclusions}

Except as noted in Appendix A, samples were collected and analyzed as planned and were within acceptable performance limits. In some instances, sample locations had to be moved due to the presence of underground utilities. These deviations are noted in applicable sections in Appendix A and did not compromise the overall site sampling strategy.

The DQIs (i.e., precision, accuracy, completeness, representativeness, comparability, and sensitivity) were evaluated for quality and impact to the data. All of the data, except data qualified as rejected, can be used in project decisions. The rejected data have been discussed and determined to have little impact on closure decisions.

Thus, the DQOs for the investigation have been met, and the data can be used to develop corrective action alternatives and to support the selection of a preferred corrective action alternative for each CAS. 


\section{B.2.0 References}

EPA, see U.S. Environmental Protection Agency.

NNSA/NSO, see U.S. Department of Energy, National Nuclear Security Administration Nevada Site Office.

NNSA/NV, see U.S. Department of Energy, National Nuclear Security Administration Nevada Operations Office.

U.S. Department of Energy, National Nuclear Security Administration Nevada Operations Office. 2002. Industrial Sites Quality Assurance Project Plan, Nevada Test Site, Nevada, Rev. 3, DOE/NV--372. Las Vegas, NV.

U.S. Department of Energy, National Nuclear Security Administration Nevada Site Office. 2003. Corrective Action Investigation Plan for Corrective Action Unit 516: Septic Systems and Discharge Points, Nevada Test Site, Nevada, DOE/NV--889. Las Vegas, NV.

U.S. Environmental Protection Agency. 1994. Contract Laboratory Program National Functional Guidelines for Inorganic Data Review, EPA/540/R-94/013. Washington, DC.

U.S. Environmental Protection Agency. 1996. Test Methods for Evaluating Solid Waste, Physical/Chemical Methods, SW-846, 3rd Edition, CD-ROM PB97-501928GEI. Washington, DC. 


\section{Appendix C}

\section{Cost Estimates for CAU 516}

(10 Pages) 


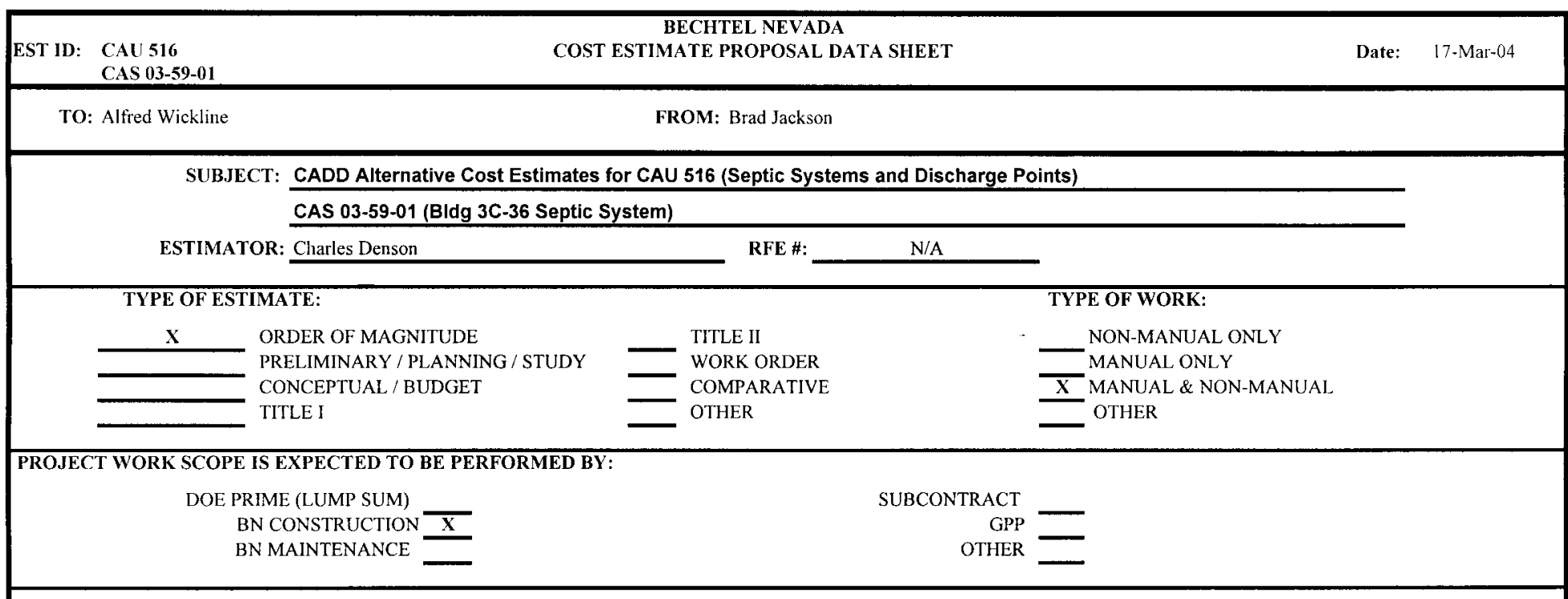

\section{STATEMENT OF WORK}

This estimate has been prepared to provide remedial alternative costs for the closure of Corrective Action Site (CAS) 03-59-01, which is included within Corrective Action Unit (CAU) 516. CAU 516 CAS 03-59-01 is an environmental restoration site listed in the Federal Facility Agreement and Consent Order (FFACO). CAS 03-59. 01 is specifically described within the FFACO as the Bldg 3C-36 Septic System.

Three aiternatives have been evaluated for closure of the CAS: I. No Further Action; II. Clean Closure; and III. Closure in Place with Administrative Controls. This estimate will be used to identify the most cost effective alternative for closure of the site while remaining protective of human health and the environment. The total estimated costs are intended for comparative analysis of clean closure and closure-in-place fieldwork and related cost only. Cost for project management, plan preparation, project support, and/or other activities are not included herein.

SCOPE:

Provide site closure using one of the following alternatives:

I) NO FURTHER ACTION

II) CLEAN CLOSURE BY EXCAVATION AND REMOVAL

III) CLOSURE IN PLACE WITH ADMINISTRATIVE CONTROLS

BASIS:

The CAS consists of one septic tank, one distribution box, one leachfield, and piping. The results of the corrective action investigation indicate that approximately 1,430 gallons of hydrocarbon-impacted materials are present within one septic tank. One distribution box present at the site was determined to not contain impacted material. Leachfield piping and/or piping contents, if any, were not characterized. Recently completed field measurements of the septic tank and laboratory analyses of samples collected of the septic tank contents indicate that approximately 1,430 gallons of hydrocarbon-impacted (7,800 mg/kg DRO) liquid/sludge/sediment is present. All waste generated at this CAS will be classified as hydrocarbon-impacted waste.

\section{ALTERNATIVE SPECIFIC BASIS OF ESTIMATE/ASSUMPTIONS}

Alternative II: Clean Closure

Septic Tank

- Construct a plastic lined basin to hold liquid/sludge from the septic tank and solidifying material

- Excavate and expose the septic tank top, and remove/break the tank top to expose the interior and allow access to the septic tank contents

- Pump the septic tank contents into the plastic lined basin and add material to solidify the liquid/sludge, solidify remaining liquid/sludge within the septic tank, remove solidified material and place into the lined basin, dispose of waste at the Area 6 hydrocarbon landfill.

- Remove the septic tank, collect verification samples (soil), backfill excavation upon receipt of acceptable verification sample results, and dispose of septic tank material at the Area 6 hydrocarbon landfill.

Distribution Box

- The distribution box is three feet in diameter by 10 feet long, oriented vertically, and constructed of reinforced concrete

- The distribution box does not contain any impacted waste.

- Remove the distribution box, backfill the excavation, and dispose of the distribution box waste as non-impacted construction debris

Piping

- Grout/seal the piping drain inlets on adjacent concrete slabs.

- Remove approximately 10 feet of piping located between the septic tank and the distribution box, and dispose of the piping waste at the Area 6 hydrocarbon landfill.

- Backfill the excavation.

Alternative III: Closure in Place with Administrative Controls

- Excavate and expose the septic tank top, and remove/break the tank top to expose the interior and allow access to the septic tank contents.

- Solidify the septic tank contents with soil or other inert material.

- Fill remaining void within septic tank with concrete, and fill the distribution box with concrete.

- Fence and place use restriction signs.

- Implement use restrictions and post-closure inspections. 


\section{ASSUMPTIONS:}

- The septic tank is approximately 10 feet by 8 feet by 5 feet and is constructed of reinforced concrete.

- Approximately 1,430 gallons of liquid/siudge is present within the septic tank.

- The distribution box has dimensions of three feet by 10 feet, is cylindrical, and is oriented vertically, constructed of concrete, and has a capacity of approximately 530 gallons. The distribution box is empty.

- The septic tank top will be removed to allow complete access for pumping and/or solidifying liquid/sludge within the tank.

- The distribution box does not contain any impacted-material, however it will be removed under Alternative II as a best management practice.

- The section of piping between the septic tank and distribution box was not characterized but is assumed to be impacted by hydrocarbons, since the septic tank up stream of the piping contains hydrocarbon-impacted liquid/sludge. The piping will be removed as a BMP during excavation to remove the septic tank and distribution box under Alternative II.

- Leachfield soil was characterized; however the piping and/or any piping contents were not characterized. Assumes a similar approach to CAU 271 will be taken where any leachfield piping encountered during the site closure activities will be inspected, screened, and any residual continents will be sampled for laboratory analysis.

- It is assumed that the areas where work will be conducted will be considered a beryllium area and additional controls will be required to complete the selected corrective actions.

- Inert material, such as soil or other media may be used to solidify the septic tank contents within the plastic lined basin and within the tank

- Post-closure Inspections are assumed to continue 10 years from the date of closure and the post-closure report is assumed to consist of a brief letter report.

- Work to be performed by BN during a "normal" workday. Shifts are based on 10-hour days / 4-days per week.

- Efficiencies will be realized if work for similar activities at similar sites can be completed concurrently.

- This estimate does not include costs for preparation of required project plans, permits, reports, mobilization and demobilization, or project management.

- Clean fill will be obtained at a barrow source located in Area 6.

- There will be no surface impediments.

- Dimensions, volumes, measurements, and analytical data provided by the characterization contractor are appropriate and accurately represent site conditions and waste characteristics.

- This estimate has been prepared for comparative purposes only based on the information provided and represents a discrete portion of the closure activities required for the site. The actual cost estimate for this site may differ from the information presented herein.

\section{ESCALATION:}

No escalation factors have been applied. All costs are in FY2004 dollars.

\section{CONTINGENCY:}

Contingency costs are not included in this estimate.

\section{RATES:}

Rates are based on FY2004 Final rates (Rev 2) effective 12/29/2003 and were applied using the BN FY2004 cost model.

\section{COST ALTERNATIVES SUMMARY:}

\section{Alternative I: No Further Action}

Alternative II:

Clean Closure

Alternative III:
$\$ 0$

\begin{tabular}{l}
$\$ 211,173$ \\
$\$ 95,273$ \\
\hline
\end{tabular}
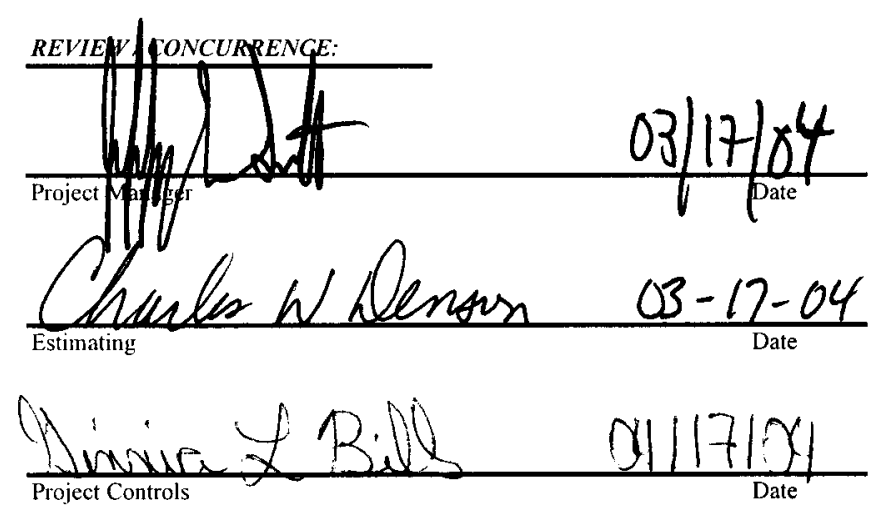


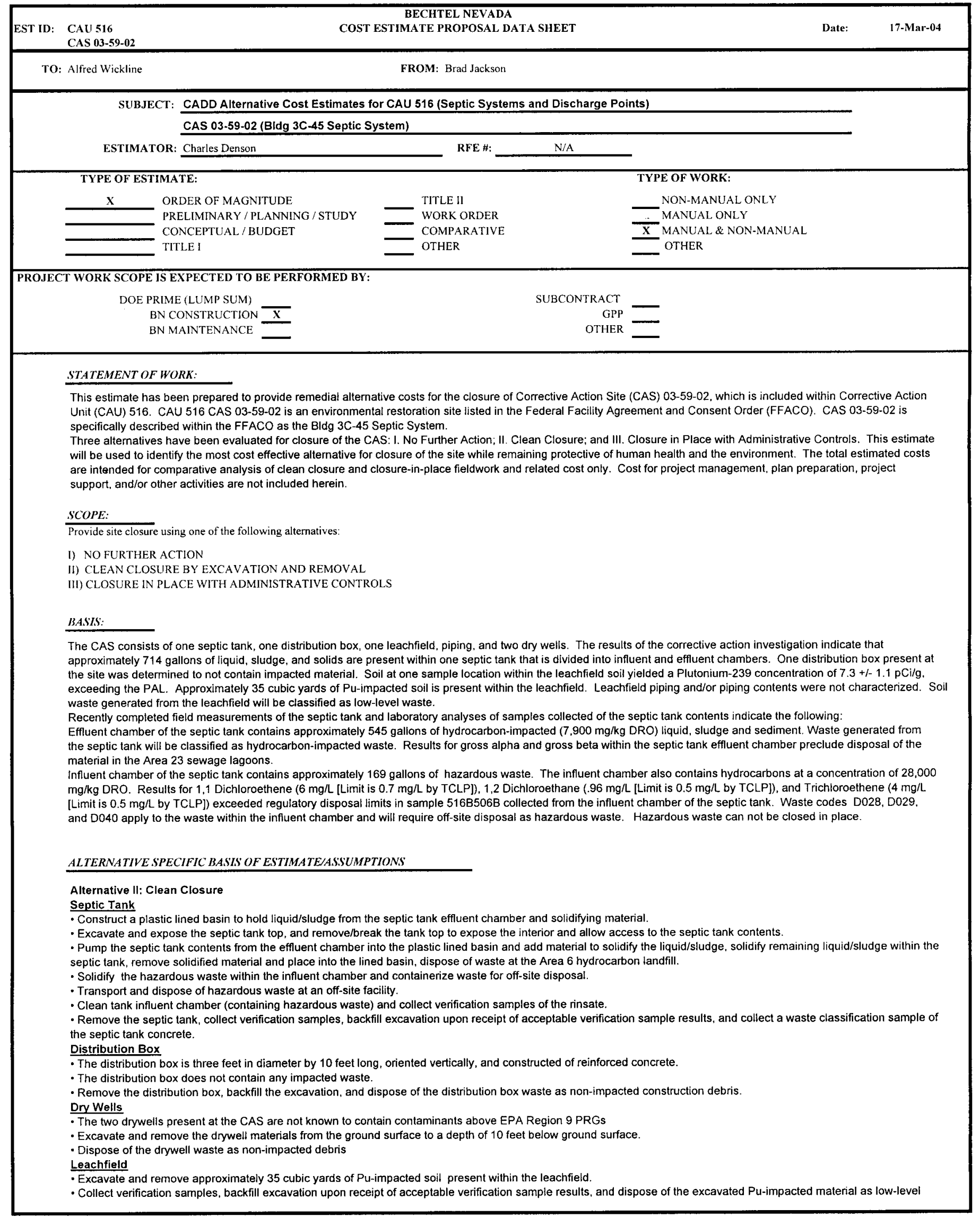




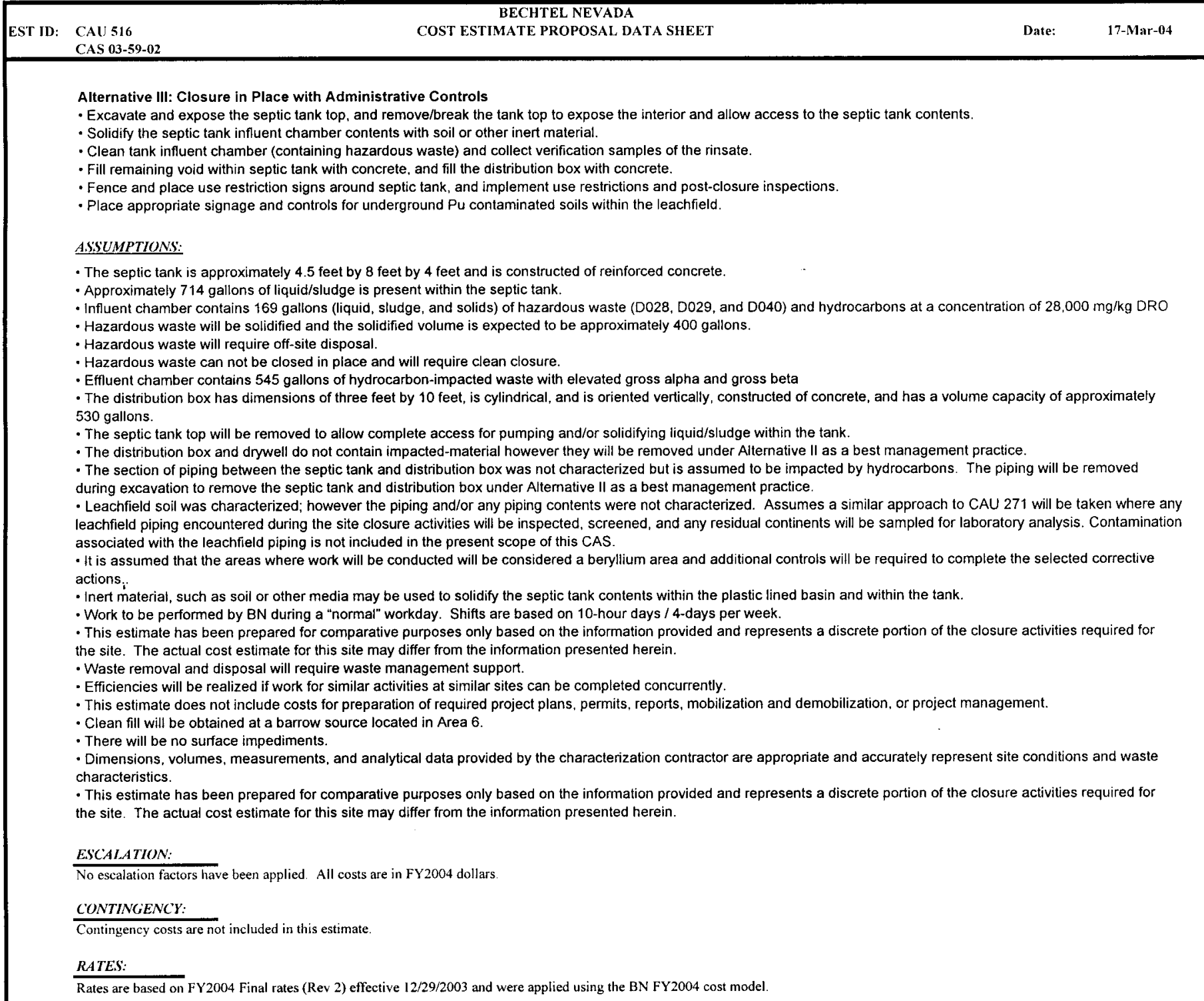

\section{COST ALTERNATIVESSUMMARY:}

$\begin{array}{llll}\text { Alternative I: } & \text { No Further Action } & \$ 0 \\ \text { Alternative II: } & \text { Clean Closure } & \$ 458,742 \\ \text { Alternative III: } & \text { Closure in Place with Administrative Controls }\end{array}$

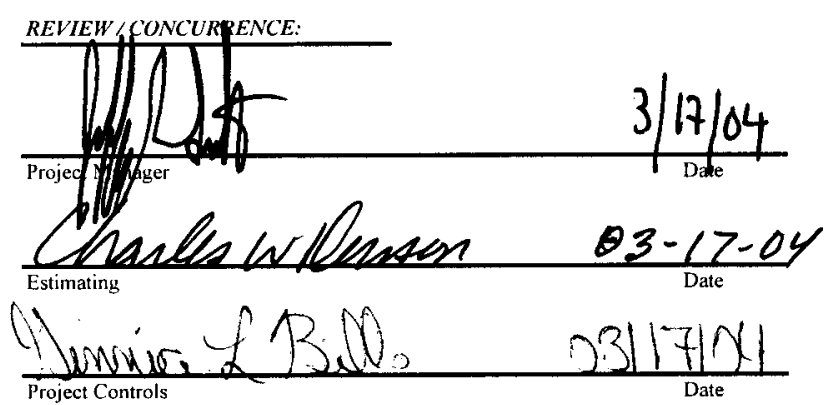




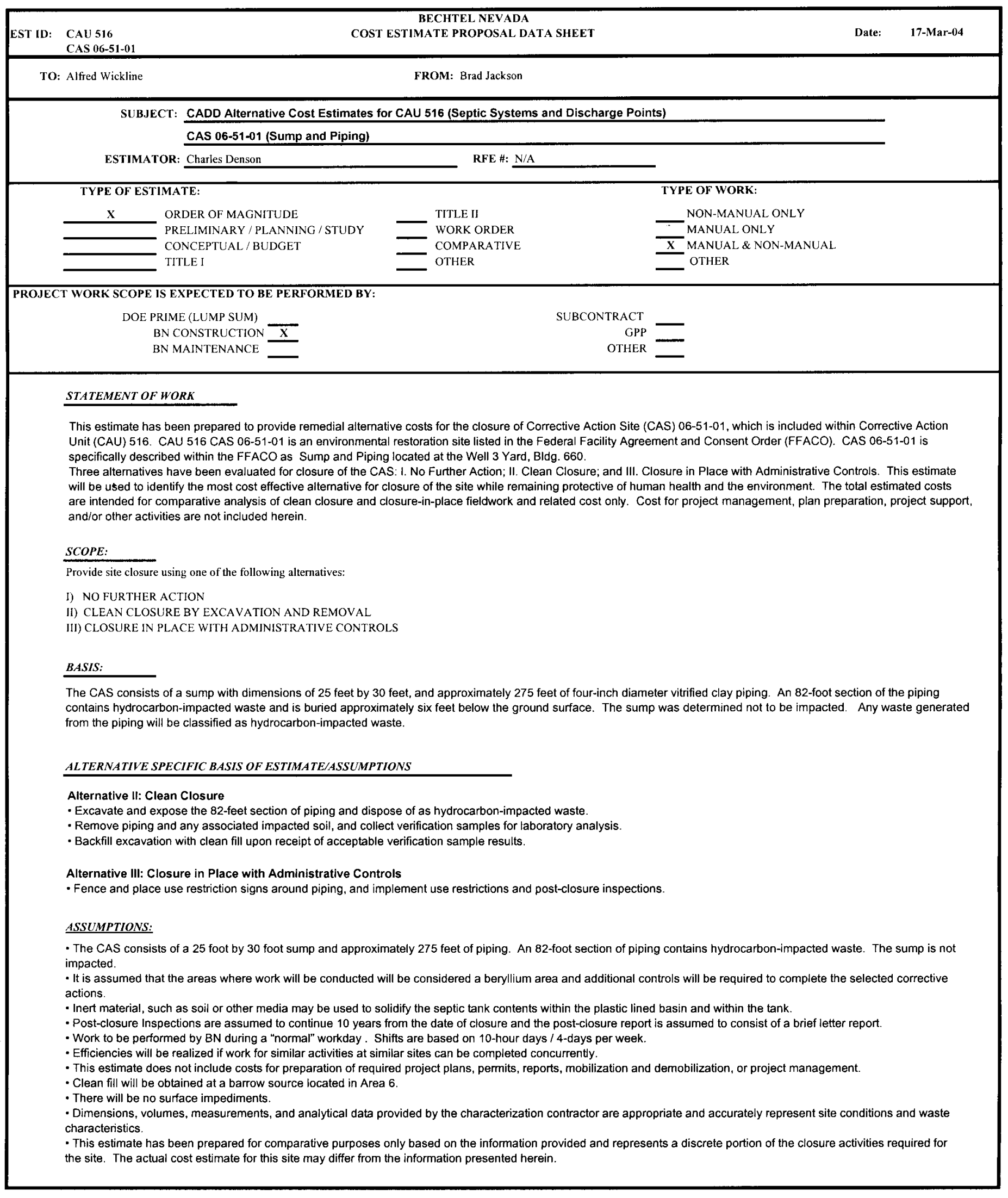


ESCALATION:

No escalation factors have been applied. All costs are in FY2004 dollars.

CONTINGENCY:

Contingency costs are not included in this estimate.

RATES:

Rates are based on FY2004 Final rates (Rev 2) effective 12/29/2003 and were applied using the BN FY2004 cost model

COSTALTERNATIVESSUMMARY:

Alternative I: No Further Action

Alternative 11: Clean Closure

Alternative llI: Closure in Place with Administrative Controls

$\$ 115,696$

$\$ 92,766$

REVIEW CONCURRENCE:

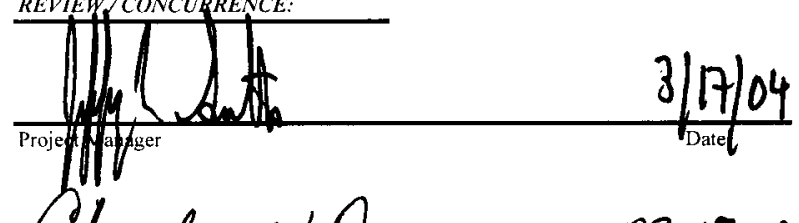

Chavles WDenson 03-97-04

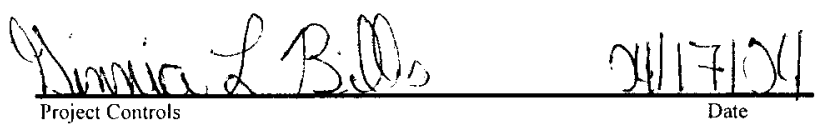


SUBJECT: CADD Alternative Cost Estimates for CAU 516 (Septic Systems and Discharge Points)

$$
\text { CAS 06-51-03 (Clean Out Box and Piping) }
$$

ESTIMATOR: Charles Denson $\quad$ RFE \#: N/A

TYPE OF ESTIMATE:

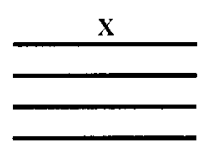

\section{ORDER OF MAGNITUDE} PRELIMINARY / PLANNING / STUDY CONCEPTUAL / BUDGET TITLE I
TYPE OF WORK:

\section{TITLE II}

WORK ORDER

COMPARATIVE

OTHER
NON-MANUAL ONLY

MANUAL ONLY

$\mathbf{X}$ MANUAL \& NON-MANUAL

OTHER

PROJECT WORK SCOPE IS EXPECTED TO BE PERFORMED BY:

DOE PRIME (LUMP SUM)

BN CONSTRUCTION

BN MAINTENANCE
SUBCONTRACT

GPP

OTHER

\section{STATEMENT OF WORK}

This estimate has been prepared to provide remedial alternative costs for the closure of Corrective Action Site (CAS) 06-51-03, which is included within Corrective Action Unit (CAU) 516. CAU 516 CAS 06-51-03 is an environmental restoration site listed in the Federal Facility Agreement and Consent Order (FFACO). CAS 06-51. 03 is specifically described within the FFACO as Clean Out Box and Piping located at the Well 3 Yard, Bldg. 660 .

Three alternatives have been evaluated for closure of the CAS: I. No Further Action; II. Clean Closure; and III. Closure in Place with Administrative Controls. This estimate will be used to identify the most cost effective alternative for closure of the site while remaining protective of human health and the environment. The total estimated costs are intended for comparative analysis of clean closure and closure-in-place fieldwork and related cost only. Cost for project management, plan preparation, project support, and/or other activities are not included herein.

\section{SCOPE:}

Provide site closure using one of the following alternatives:

I) NO FURTHER ACTION

II) CLEAN CLOSURE BY EXCAVATION AND REMOVAL

III) CLOSURE IN PLACE WITH ADMINISTRATIVE CONTROLS

\section{BASIS:}

The CAS consists of one cleanout box and approximately 25 feet of associated four-inch clay piping. The cleanout box contains approximately two cubic feet of hydrocarbon-impacted waste $(180 \mathrm{mg} / \mathrm{kg}$ DRO). The piping is also hydrocarbon impacted. The top of the cleanout box is located at the ground surface and the base is two feet below ground surface. The piping is assumed to be present at a depth of two feet below ground surface. Any waste generated from the cleanout box and/or piping will be classified as hydrocarbon-impacted waste.

\section{ALTERNATIVE SPECIFIC BASIS OF ESTIMATE/ASSUMPTIONS}

Alternative II: Clean Closure

Cleanout Box

- Remove cleanout box and any associated impacted soil, and collect verification samples for laboratory analysis

- Backfill excavation with clean fill upon receipt of acceptable verification sample results.

Piping

- Remove approximately 25 feet of piping associated with the cleanout box and dispose of the piping waste at the Area 6 hydrocarbon landfill

- Collect verification samples and backfill the excavation

Alternative III: Closure in Place with Administrative Controls

- Fence and place use restriction signs around cleanout box and piping, and implement use restrictions and post-closure inspections. 


\section{ASSUMPTIONS:}

- The CAS consists of one cleanout box that contains hydrocarbon-impacted sediment, and approximately 25 feet of associated four-inch clay piping that is also hydrocarbon impacted.

- It is assumed that the areas where work will be conducted will be considered a beryllium area and additional controls will be required to complete the selected corrective actions.

- Post-closure Inspections are assumed to continue 10 years from the date of closure and the post-closure report is assumed to consist of a brief letter report.

- Work to be performed by BN during a "normal" workday. Shifts are based on 10-hour days / 4-days per week.

- Efficiencies will be realized if work for similar activities at similar sites can be completed concurrently.

- This estimate does not include costs for preparation of required project plans, permits, reports, mobilization and demobilization, or project management.

- Clean fill will be obtained at a barrow source located in Area 6.

- There will be no surface impediments

- Dimensions, volumes, measurements, and analytical data provided by the characterization contractor are appropriate and accurately represent site conditions and waste characteristics.

- This estimate has been prepared for comparative purposes only based on the information provided and represents a discrete portion of the closure activities required for the site. The actual cost estimate for this site may differ from the information presented herein.

ESCALATION:

No escalation factors have been applied. All costs are in FY2004 dollars.

CONTINGENCY:

Contingency costs are not included in this estimate.

\section{RATES:}

Rates are based on FY2004 Final rates (Rev 2) effective 12/29/2003 and were applied using the BN FY2004 cost model.

COST ALTERNATIVES SUMMARY:

\section{Alternative I: $\quad$ No Further Action}

Alternative II:

Clean Closure

Alternative III: $\underline{\text { so }}$

$\$ 141,903$

$\$ 92.766$

REVIEW/CONCURRENCE:
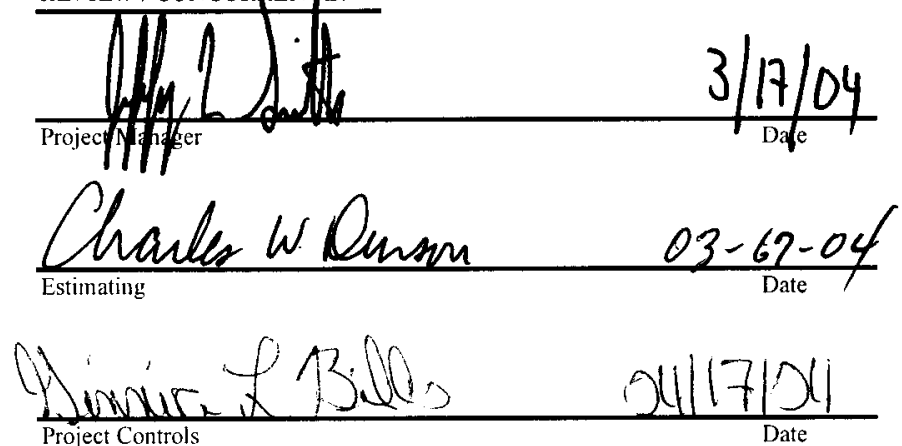


\begin{tabular}{|c|c|c|c|c|}
\hline EST ID: & $\begin{array}{l}\text { CAU } 516 \\
\text { CAS 22-19-04 }\end{array}$ & $\begin{array}{c}\text { BECHTEL NEVADA } \\
\text { COST ESTIMATE PROPOSAL DATA SHEET }\end{array}$ & Date: & 17-Mar-04 \\
\hline
\end{tabular}

TO: Alfred Wickline

FROM: Brad Jackson

SUBJECT: CADD Alternative Cost Estimates for CAU 516 (Septic Systems and Discharge Points)

CAS 22-19-04 (Vehicle Decontamination Area)

ESTIMATOR: Charles Denson RFE \#: N/A

TYPE OF ESTIMATE:

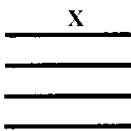

TITLE I
ORDER OF MAGNITUDE

PRELIMINARY / PLANNING / STUDY

CONCEPTUAL / BUDGET

\section{TYPE OF WORK:}

NON-MANUAL ONLY

MANUAL ONLY

$\bar{X}$ MANUAL \& NON-MANUAL

OTHER

\section{PROJECT WORK SCOPE IS EXPECTED TO BE PERFORMED BY:}

DOE PRIME (LUMP SUM)
BN CONSTRUCTION

BN MAINTENANCE
SUBCONTRACT

GPP

OTHER

\section{STATEMENT OF WORK}

This estimate has been prepared to provide remedial alternative costs for the closure of Corrective Action Site (CAS) 22-19-04, which is included within Corrective Action Unit (CAU) 516. CAU 516 CAS 22-19-04 is an environmental restoration site listed in the Federal Facility Agreement and Consent Order (FFACO). CAS 22 19-04 is specifically described within the FFACO Vehicle Decontamination Area located near the Desert Rock Airport.

Three alternatives have been evaluated for closure of the CAS: I. No Further Action; II. Clean Closure; and III. Closure in Place with Administrative Controls. This estimate will be used to identify the most cost effective alternative for closure of the site while remaining protective of human health and the environment. The total estimated costs are intended for comparative analysis of clean closure and closure-in-place fieldwork and related cost only. Cost for project management, plan preparation, project support, and/or other activities are not included herein.

SCOPE:

Provide site closure using one of the following alternatives:

I) NO FURTHER ACTION

II) CLEAN CLOSURE BY EXCAVATION AND REMOVAL

III) CLOSURE IN PLACE WITH ADMINISTRATIVE CONTROLS

BASIS:

The CAS consists of a vehicle decontamination area used during the operation of Camp Desert Rock. No Constituents of Potential Concern (COPCs) above action levels were detected during the CAl.

\section{ALTERNATIVE SPECIFIC BASIS OF ESTIMATE/ASSUMPTIONS}

Alternative : No Further Action

No COPCs above action levels were detected during the CAI

Alternative II: Clean Closure

Not Applicable

Alternative III: Closure in Place with Administrative Controls

Not Applicable

\section{ASSUMPTIONS:}

The CAS consists of a vehicle decontamination area used during the operation of Camp Desert Rock. No COPCs above action levels were detected during the CAl.

\section{ESCALATION:}

No escalation factors have been applied. All costs are in FY2004 dollars.

\section{CONTINGENCY:}

Contingency costs are not included in this estimate.

\section{RATES:}

Rates are based on FY2004 final rates (Rev 2) effective 12/29/2003 and were applied using the BN FY2004 cost model.

\section{COST ALTERNATIVES SUMMARY:}

Alternative I: $\quad$ No Further Action

Alternative II: Clean Closure

Alternative III: Closure in Place with Administrative Controls

\begin{tabular}{|c|}
\hline$\$ 0$ \\
\hline So \\
\hline \$o \\
\hline
\end{tabular}




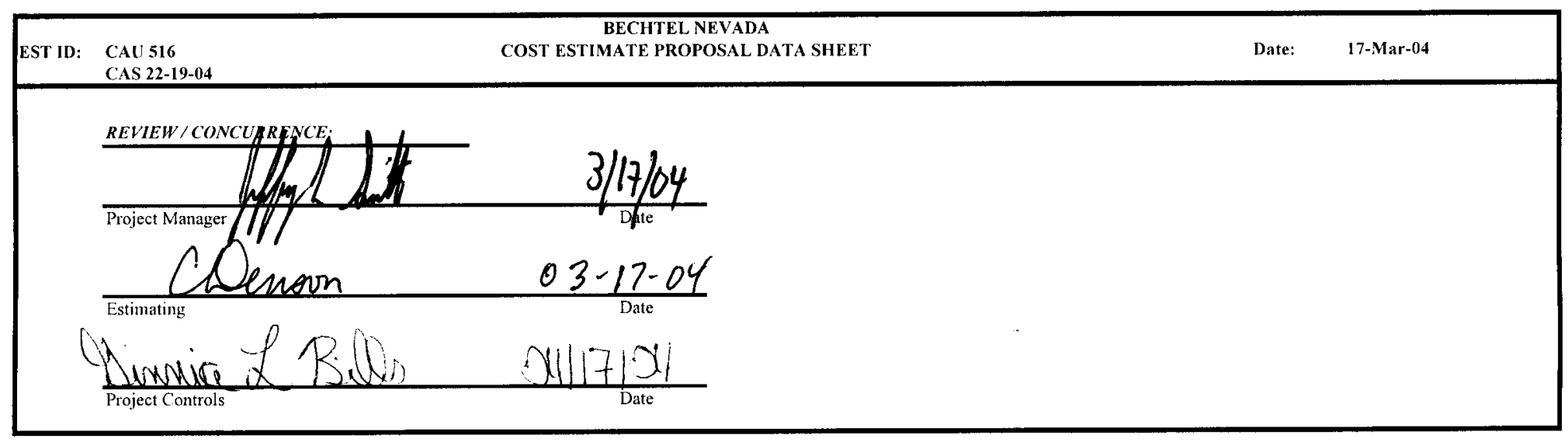




\section{Appendix D}

Sample Location Coordinates for CAU 516 


\section{D.1.0 Sample Location Coordinates}

Sample location coordinates were measured during the corrective action investigation using a Trimble GPS, Model TSCI. These coordinates identify the sampling locations (e.g., latitude, longitude, standard deviation, elevation) at each CAS in CAU 516. Data are reported as Universal Traverse Mercator (UTM), Zone 11, North American Datum (NAD) 27.

\section{D.1.1 CAS 03-59-01, Bldg 3C-36 Septic System}

Sample locations at CAS 03-59-01 are shown on Figure A.3-1. The corresponding coordinates for CAS 03-59-01 sample locations are listed in Table D.1-1 and plotted on Figure D.1-1.

\section{D.1.2 CAS 03-59-02, BIdg 3C-45 Septic System}

Sample locations at CAS 03-59-02 are shown on Figure A.4-1. The corresponding coordinates for CAS 03-59-02 sample locations are listed in Table D.1-2 and plotted on Figure D.1-2. The coordinates for sample location B08 were not measured.

\section{D.1.3 CAS 06-51-01, Sump and Piping}

Sample locations at CAS 06-51-01 are shown on Figure A.5-1. The corresponding coordinates for CAS 06-51-01 sample locations are listed in Table D.1-3 and plotted on Figure D.1-3.

\section{D.1.4 CAS 06-51-02, Clay Pipe and Debris}

Sample location coordinates were not measured at this CAS because soil samples were not collected.

\section{D.1.5 CAS 06-51-03, Clean Out Box and Piping}

Sample locations at CAS 06-51-03 are shown on Figure A.5-1. The corresponding coordinates for CAS 06-51-03 sample locations are listed in Table D.1-4 and plotted on Figure D.1-3. 


\section{D.1.6 CAS 22-19-04, Vehicle Decontamination Area}

Sample locations at CAS 22-19-04 are shown on Figure A.8-1. The corresponding coordinates for CAS 22-19-04 sample locations are listed in Table D.1-5 and plotted on Figure D.1-4. The standard deviations were not reported for the coordinates measured at this CAS.

Table D.1-1

Sample Location Coordinates ${ }^{a}$ for CAS 03-59-01

\begin{tabular}{|c|c|c|c|c|c|c|}
\hline Location & Latitude & Longitude & $\begin{array}{l}\text { Northing } \\
\text { (meters) }\end{array}$ & $\begin{array}{l}\text { Easting } \\
\text { (meters) }\end{array}$ & $\begin{array}{l}\text { Standard } \\
\text { Deviation }\end{array}$ & $\begin{array}{c}\text { HAE } \\
\text { (meters) }\end{array}$ \\
\hline $\mathrm{A} 01$ & 37.0352833 & -116.0384994 & 4099015.394 & 585514.19 & 0.149479 & 1218.101 \\
\hline $\mathrm{A} 02$ & 37.03511175 & -116.0384961 & 4098996.366 & 585514.684 & 1.074397 & 1217.762 \\
\hline $\mathrm{A} 03$ & 37.03523307 & -116.0385001 & 4099009.82 & 585514.189 & 0.042265 & 1217.964 \\
\hline $\mathrm{A} 04$ & 37.03521978 & -116.038495 & 4099008.351 & 585514.653 & 0.06759 & 1217.121 \\
\hline A05 & 37.03518026 & -116.0385063 & 4099003.957 & 585513.698 & 0.182259 & 1216.905 \\
\hline A06 & 37.03510102 & -116.0384957 & 4098995.175 & 585514.727 & 0.076207 & 1217.8 \\
\hline$A 06 b$ & 37.03508748 & -116.0384955 & 4098993.673 & 585514.758 & 0.059037 & 1217.429 \\
\hline $\mathrm{A} 07$ & 37.03514779 & -116.0384993 & 4099000.36 & 585514.355 & 0.033263 & 1218.061 \\
\hline A08 & 37.03514598 & -116.0384811 & 4099000.177 & 585515.98 & 0.051145 & 1218.342 \\
\hline A09 & 37.03509118 & -116.0384706 & 4098994.106 & 585516.974 & 0.146611 & 1216.768 \\
\hline A10 & 37.03518127 & -116.0384815 & 4099004.091 & 585515.903 & 0.04681 & 1217.355 \\
\hline A11 & 37.03517931 & -116.0385361 & 4099003.824 & 585511.05 & 0.133141 & 1216.771 \\
\hline A12 & 37.03514817 & -116.038533 & 4099000.373 & 585511.361 & 0.034702 & 1217.997 \\
\hline A13 & 37.035097 & -116.0385349 & 4098994.694 & 585511.241 & 0.260947 & 1216.118 \\
\hline A14 & 37.03507462 & -116.0385177 & 4098992.227 & 585512.798 & 0.169345 & 1217.958 \\
\hline A15 & 37.03507478 & -116.0384806 & 4098992.278 & 585516.096 & 0.307754 & 1215.902 \\
\hline A16 & 37.03512755 & -116.0385011 & 4098998.114 & 585514.218 & 0.062316 & 1218.119 \\
\hline
\end{tabular}

${ }^{\mathrm{a} C}$ Coordinates reported in UTM, Zone 11, NAD 27

HAE $=$ Height Above Ellipsoid 


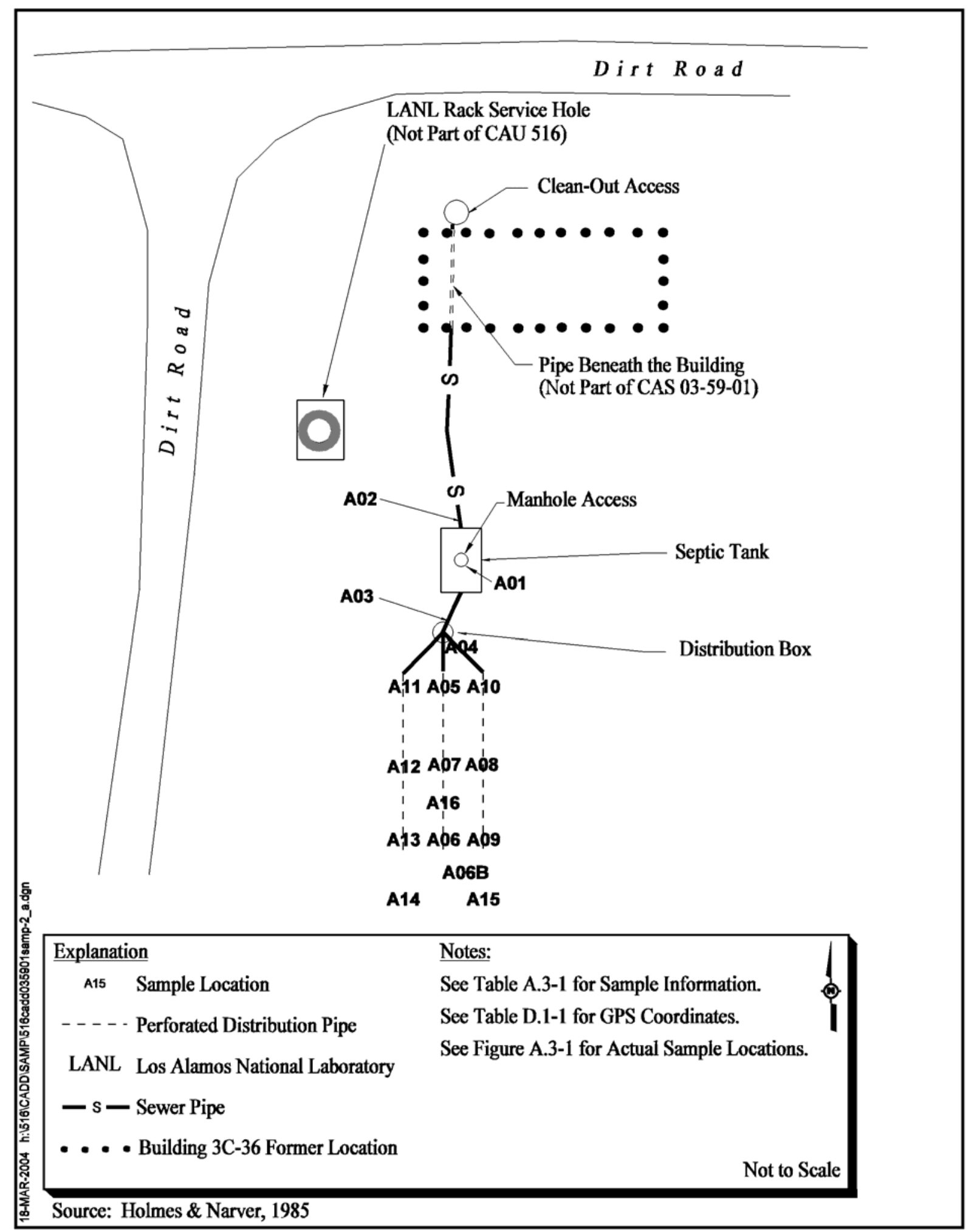

Figure D.1-1

CAU 516, CAS 03-59-01, BIdg 3C-36 Septic System, GPS Coordinate Locations 
Table D.1-2

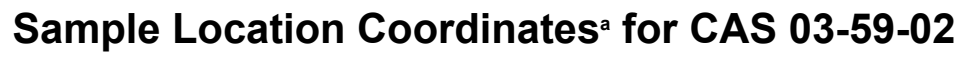

\begin{tabular}{|c|c|c|c|c|c|c|}
\hline Location & Latitude & Longitude & $\begin{array}{l}\text { Northing } \\
\text { (meters) }\end{array}$ & $\begin{array}{l}\text { Easting } \\
\text { (meters) }\end{array}$ & $\begin{array}{l}\text { Standard } \\
\text { Deviation }\end{array}$ & $\begin{array}{c}\text { HAE } \\
\text { (meters) }\end{array}$ \\
\hline B01 & 37.03763679 & -116.0341451 & 4099280.403 & 585898.819 & 0.226291 & 1217.802 \\
\hline B02 & 37.03765699 & -116.034132 & 4099282.656 & 585899.961 & 0.041421 & 1217.953 \\
\hline B03 & 37.03788711 & -116.0339229 & 4099308.373 & 585918.3 & 0.094788 & 1217.757 \\
\hline B04 & 37.03787304 & -116.0339319 & 4099306.805 & 585917.514 & 0.070375 & 1217.054 \\
\hline B05 & 37.03792823 & -116.0339383 & 4099312.921 & 585916.883 & 0.038694 & 1217.426 \\
\hline B06 & 37.03791774 & -116.0338945 & 4099311.797 & 585920.787 & 0.065744 & 1217.544 \\
\hline B07 & 37.03791138 & -116.0338443 & 4099311.137 & 585925.26 & 0.94864 & 1217.029 \\
\hline $\mathrm{B}^{\mathrm{b}} \mathrm{g}^{\mathrm{b}}$ & 37.03807137 & -116.0338284 & 4099328.9 & 585926.496 & 0.123367 & 1218.248 \\
\hline B10 & 37.03807267 & -116.0338284 & 4099329.044 & 585926.489 & 0.021284 & 1217.697 \\
\hline B11 & 37.03796907 & -116.0337714 & 4099317.602 & 585931.678 & 0.114632 & 1214.522 \\
\hline B12 & 37.03798176 & -116.0338179 & 4099318.968 & 585927.529 & 0.202271 & 1218.193 \\
\hline B13 & 37.03800533 & -116.0338732 & 4099321.533 & 585922.581 & 0.047205 & 1218.691 \\
\hline B14 & 37.03802173 & -116.0339192 & 4099323.311 & 585918.473 & 0.154582 & 1214.37 \\
\hline B15 & 37.03793433 & -116.0339734 & 4099313.567 & 585913.751 & 0.891939 & 1217.633 \\
\hline B16 & 37.03810929 & -116.0337548 & 4099333.173 & 585932.996 & 0.042721 & 1219 \\
\hline B17 & 37.03809739 & -116.0337607 & 4099331.848 & 585932.485 & 0.042636 & 1219.059 \\
\hline B18 & 37.0381063 & -116.0337655 & 4099332.831 & 585932.05 & 0.99722 & 1218.567 \\
\hline B19 & 37.0381035 & -116.0337185 & 4099332.564 & 585936.231 & 0.460283 & 1218.586 \\
\hline B20 & 37.03775109 & -116.034489 & 4099292.772 & 585868.101 & 0.032651 & 1218.585 \\
\hline B21 & 37.03775302 & -116.0345083 & 4099292.97 & 585866.386 & 0.063764 & 1218.83 \\
\hline B22 & 37.03776996 & -116.034538 & 4099294.821 & 585863.726 & 0.102166 & 1214.801 \\
\hline B23 & 37.03764831 & -116.0340653 & 4099281.754 & 585905.9 & 0.221225 & 1212.477 \\
\hline B24 & 37.03769404 & -116.0341365 & 4099286.762 & 585899.521 & 0.074162 & 1218.771 \\
\hline B25 & 37.03761917 & -116.0341731 & 4099278.423 & 585896.343 & 0.205949 & 1215.064 \\
\hline B26 & 37.03766679 & -116.0341192 & 4099283.755 & 585901.084 & 0.098028 & 1215.108 \\
\hline B27 & 37.03789592 & -116.0339333 & 4099309.341 & 585917.358 & 0.314111 & 1215.411 \\
\hline $\mathrm{B} 28$ & 37.03783552 & -116.0339578 & 4099302.619 & 585915.254 & 0.227028 & 1215.341 \\
\hline B29 & 37.03784234 & -116.0338934 & 4099303.433 & 585920.973 & 0.108725 & 1217.79 \\
\hline B30 & 37.03786747 & -116.0338431 & 4099306.267 & 585925.413 & 0.273508 & 1217.046 \\
\hline B31 & 37.0379137 & -116.0338163 & 4099311.42 & 585927.75 & 0.962977 & 1217.669 \\
\hline B32 & 37.0379404 & -116.0338553 & 4099314.347 & 585924.245 & 0.132512 & 1218.221 \\
\hline B33 & 37.03795347 & -116.0339185 & 4099315.739 & 585918.615 & 0.203862 & 1217.743 \\
\hline
\end{tabular}

HAE = Height Above Ellipsoid 


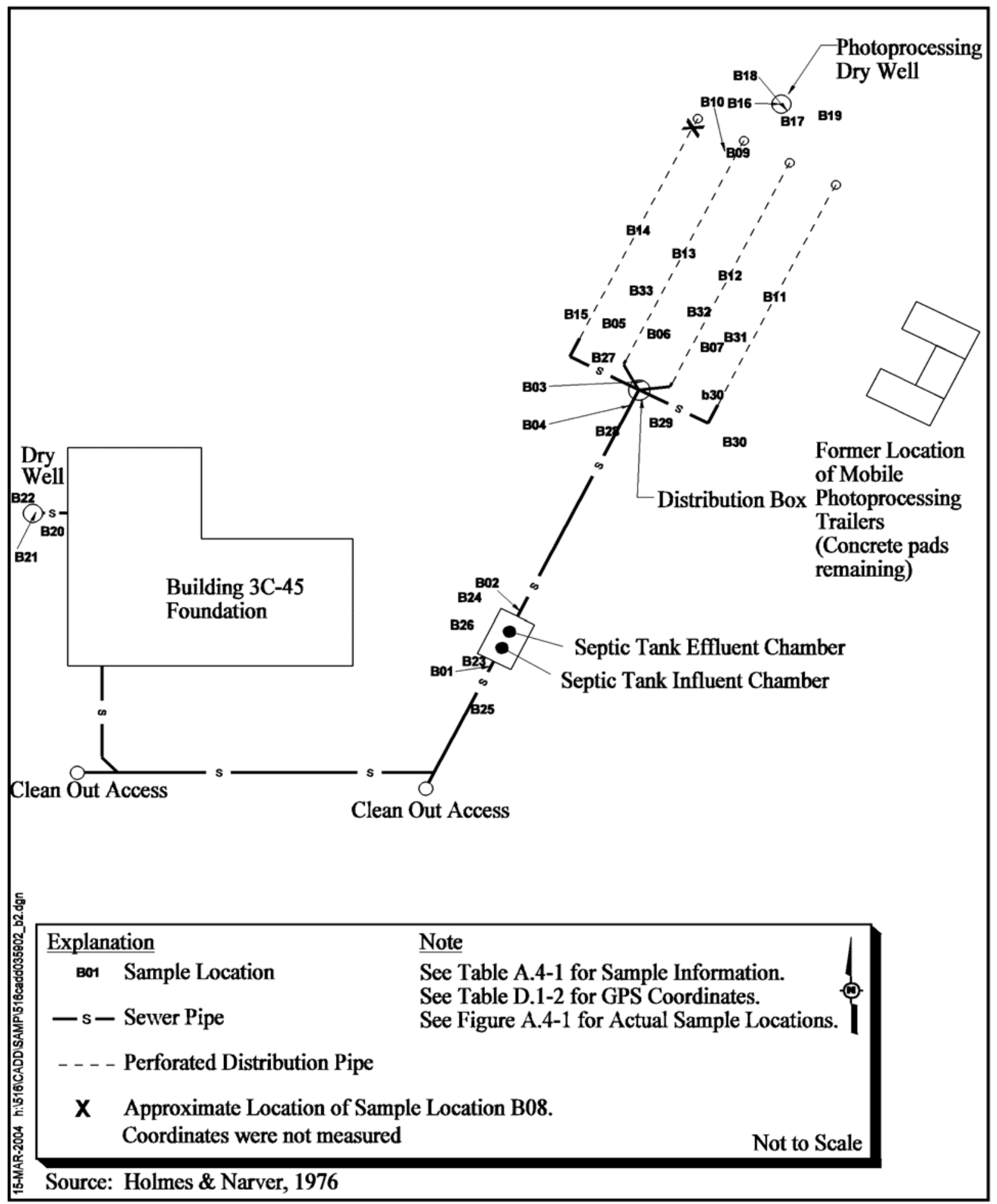

Figure D.1-2

CAU 516, CAS 03-59-02, BIdg 3C-45 Septic System, GPS Coordinate Locations 
Table D.1-3

Sample Location Coordinates ${ }^{\text {a }}$ for CAS 06-51-01

\begin{tabular}{|c|c|c|c|c|c|c|}
\hline Location & Latitude & Longitude & $\begin{array}{c}\text { Northing } \\
\text { (meters) }\end{array}$ & $\begin{array}{c}\text { Easting } \\
\text { (meters) }\end{array}$ & $\begin{array}{c}\text { Standard } \\
\text { Deviation }\end{array}$ & $\begin{array}{c}\text { HAE } \\
\text { (meters) }\end{array}$ \\
\hline \hline C01 & 36.99693847 & -116.058085 & 4094744.176 & 583814.328 & 0.060495 & 1207.136 \\
\hline C02 & 36.99686897 & -116.058084 & 4094736.467 & 583814.494 & 0.617464 & 1199.014 \\
\hline C03 & 36.99699747 & -116.058079 & 4094750.727 & 583814.81 & 0.153246 & 1206.848 \\
\hline C04 & 36.99706476 & -116.058022 & 4094758.242 & 583819.858 & 0.237978 & 1204.635 \\
\hline C05 & 36.99707864 & -116.058196 & 4094759.628 & 583804.301 & 0.22986 & 1203.29 \\
\hline C06 & 36.99712697 & -116.058128 & 4094765.05 & 583810.357 & 0.07999 & 1206.632 \\
\hline C07 & 36.99697505 & -116.058086 & 4094748.234 & 583814.237 & 0.156438 & 1207.267 \\
\hline C08 & 36.9970468 & -116.0582 & 4094756.092 & 583803.953 & 0.04467 & 1205.802 \\
\hline C10 & 36.99614455 & -116.058081 & 4094656.107 & 583815.578 & 12.18983 & 1198.274 \\
\hline
\end{tabular}

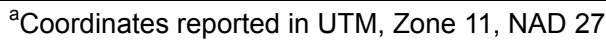

HAE = Height Above Ellipsoid 


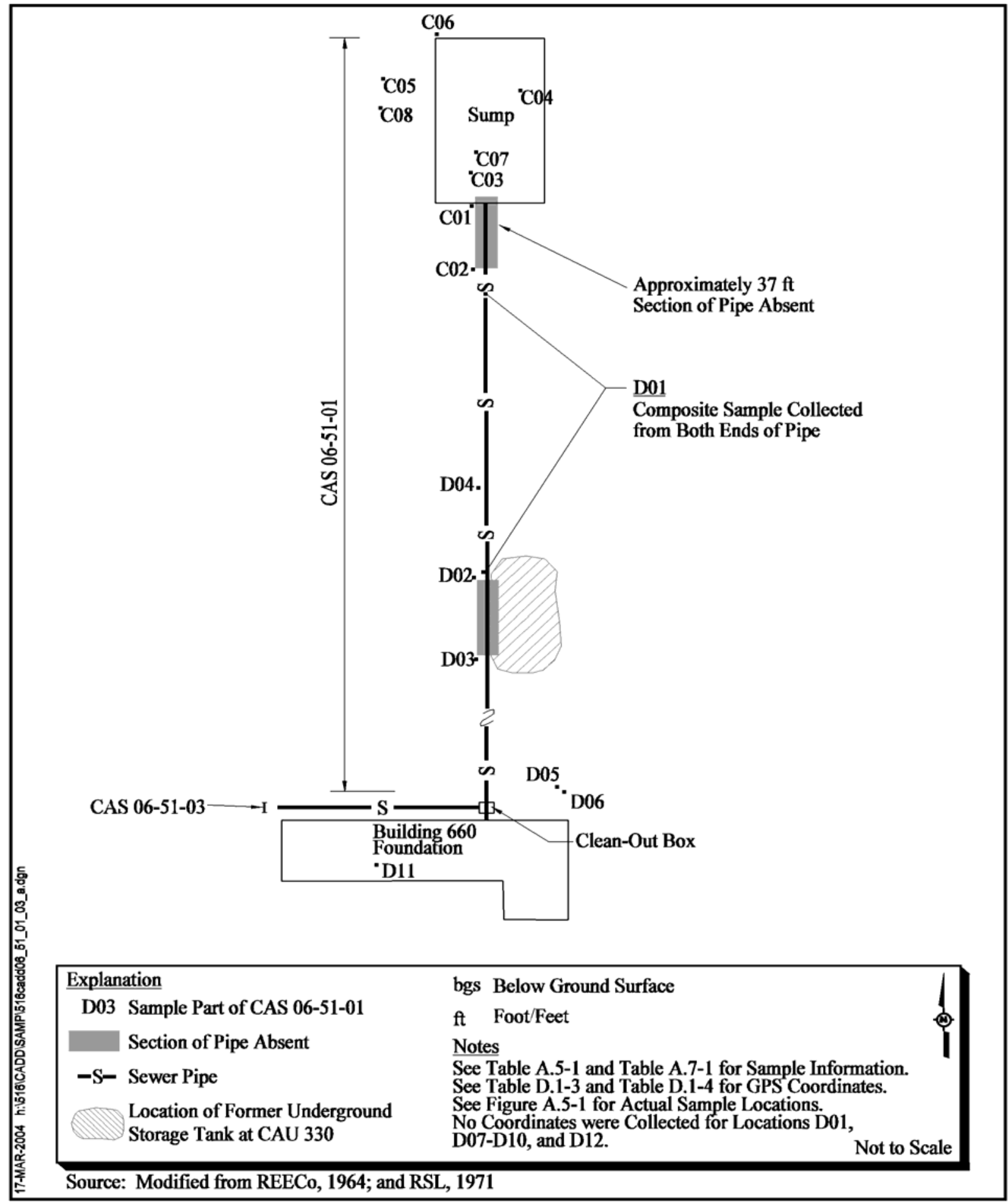

Figure D.1-3

CAU 516, CAS 06-51-01, Sump and Piping, and CAS 06-51-03, Clean Out Box and Piping, GPS Coordinate Locations 
Table D.1-4

Sample Location Coordinates ${ }^{\text {a }}$ for CAS 06-51-03

\begin{tabular}{|c|c|c|c|c|c|c|}
\hline Location $^{\mathrm{b}}$ & Latitude & Longitude & $\begin{array}{c}\text { Northing } \\
\text { (meters) }\end{array}$ & $\begin{array}{c}\text { Easting } \\
\text { (meters) }\end{array}$ & $\begin{array}{c}\text { Standard } \\
\text { Deviation }\end{array}$ & $\begin{array}{c}\text { HAE } \\
\text { (meters) }\end{array}$ \\
\hline \hline D02 & 36.99653121 & -116.058088 & 4094698.994 & 583814.555 & 0.048623 & 1202.799 \\
\hline D03 & 36.9964422 & -116.058086 & 4094689.121 & 583814.816 & 0.552238 & 1200.848 \\
\hline D04 & 36.99662959 & -116.05808 & 4094709.914 & 583815.092 & 0.78056 & 1201.198 \\
\hline $\begin{array}{c}\text { West Pipe } \\
\text { D11 }\end{array}$ & 36.99621802 & -116.058216 & 4094664.138 & 583803.478 & 0.235321 & 1202.312 \\
\hline
\end{tabular}

${ }^{\mathrm{a}}$ Coordinates reported in UTM, Zone 11, NAD 27

${ }^{b}$ No coordinates were collected for D01, D07 - 010, and D12

HAE = Height Above Ellipsoid

Table D.1-5

Sample Location Coordinates ${ }^{\mathrm{a}}$ for CAS 22-19-04

\begin{tabular}{|c|c|c|c|c|c|}
\hline Location $^{\mathbf{b}}$ & Latitude & Longitude & $\begin{array}{c}\text { Northing } \\
\text { (meters) }\end{array}$ & $\begin{array}{c}\text { Easting } \\
\text { (meters) }\end{array}$ & $\begin{array}{c}\text { HAE } \\
\text { (meters) }\end{array}$ \\
\hline \hline E004 & 36.6219 & -116.0216 & 4053170.3 & 587483.0 & 1022.97 \\
\hline E005 & 36.6218 & -116.0216 & 4053167.0 & 587482.4 & 1022.66 \\
\hline E006 & 36.6218 & -116.0217 & 4053163.5 & 587481.1 & 1021.73 \\
\hline Basin $^{c}$ & 36.6218 & -116.0218 & 4053166.1 & 587470.2 & 1021.98 \\
\hline Ditch $^{d}$ & 36.6218 & -116.0217 & 4053166.5 & 587473.4 & 1021.32 \\
\hline
\end{tabular}

${ }^{\mathrm{a} C}$ Coordinates reported as UTM, Zone 11, NAD 27

${ }^{\mathrm{b}}$ There is no sample location E03.

'Sample location of basin is E01.

${ }^{\mathrm{d}}$ Sample location of ditch is E02.

HAE $=$ Height Above Ellipsoid 


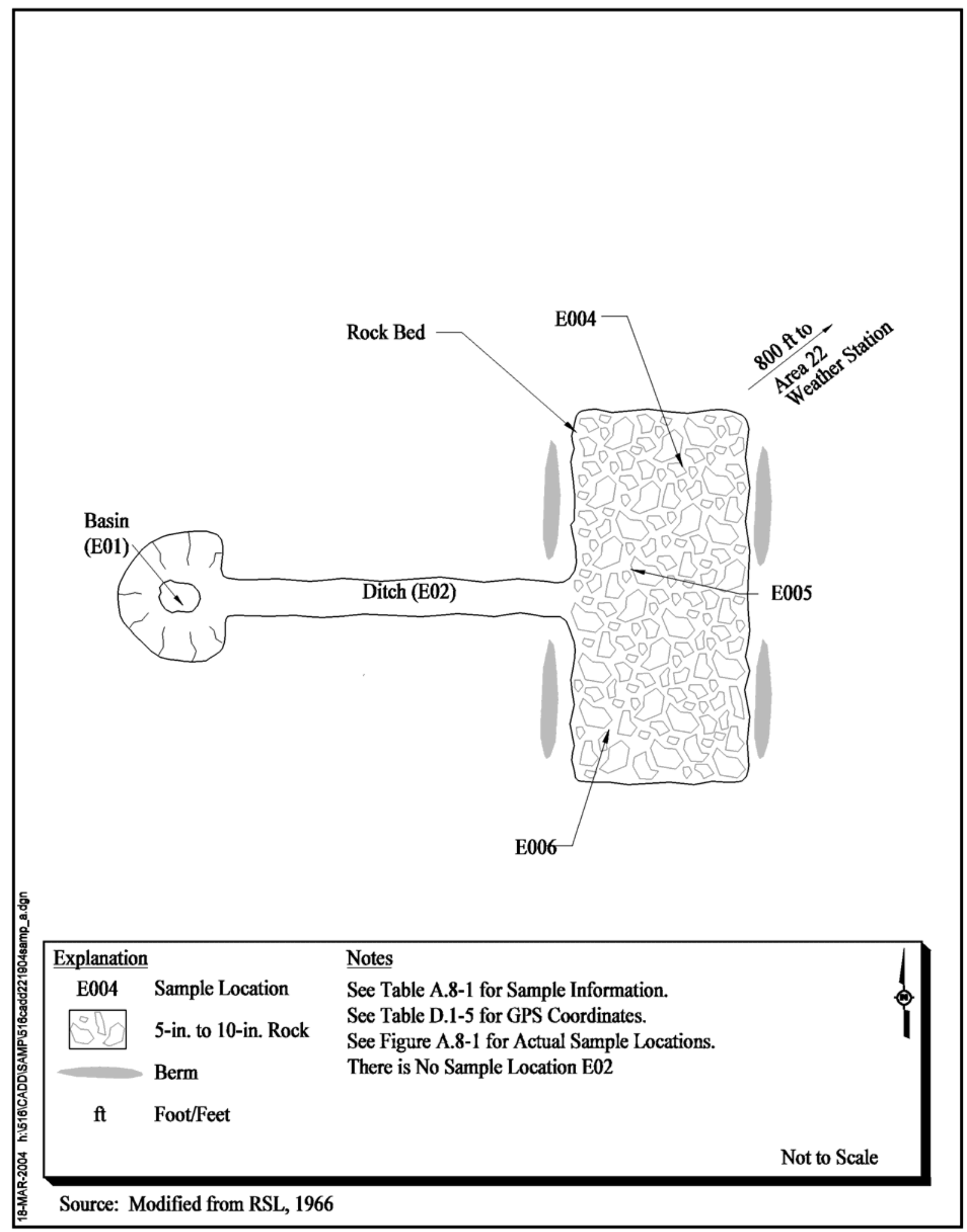

Figure D.1-4

CAU 516, CAS 22-19-04, Vehicle Decontamination Area

GPS Coordinate Locations 


\section{D.2.0 References}

Holmes \& Narver, Inc. 1976. Engineering Drawing JS-003-3C-45-C2.1 entitled, "Nevada Test Site Area 3 LASL Building 3C-45 Rack and Compensator Fac. Addition Surface Treatment," 19 January. Mercury, NV: Archives and Records Center.

Holmes \& Narver, Inc. 1985. Engineering Drawing JS-003-3C-36-C1.1 entitled, "Nevada Test Site Area 3 - Los Alamos Building No. 3C-36 WX-9 Office Complex Plot \& Grading Plan Details," 23 January. Mercury, NV: Archives and Records Center.

REECo, see Reynolds Electrical \& Engineering Co., Inc.

RSL, see Remote Sensing Laboratory.

Remote Sensing Laboratory. 1966. Aerial photographs of CAU 516, CAS 22-19-04. Nellis Air Force Base, NV: Photo Archives Library.

Remote Sensing Laboratory. 1971. Aerial Photograph of Well 3 Yard. Nellis Air Force Base, NV: Photo Archives Library.

Reynolds Electrical \& Engineering Co., Inc. 1964. Engineering Drawing RE-791A entitled, "U.S. Public Health Service Facilities for Milk Cows Plot Plan," December. Mercury, NV: Archives and Record Center. 


\section{Appendix E}

\section{Project Organization for CAU 516}




\section{E.1.0 Project Organization}

The NNSA/NSO Project Manager is Janet Appenzeller-Wing, and her telephone number is (702) 295-0461.

The identification of the project Health and Safety Officer and the Quality Assurance Officer can be found in the appropriate NNSA/NSO plan. However, personnel are subject to change and it is suggested that the appropriate NNSA/NSO Project Manager be contacted for further information. The NNSA/NSO Task Manager will be identified in the FFACO Biweekly Activity Report prior to the start of field activities. 


\section{Appendix F}

\section{NDEP Comments}


NEVADA ENVIRONMENTAL RESTORATION PROJECT

DOCUMENT REVIEW SHEET

\begin{tabular}{|c|c|c|c|c|}
\hline \multicolumn{3}{|c|}{$\begin{array}{l}\text { 1. Document Title/Number: Draft Corrective Decision Document for Corrective Action Unit 516: } \\
\text { Septic Systems and Discharge Points, Nevada Test Site, Nevada }\end{array}$} & \multicolumn{2}{|l|}{ 2. Document Date: January 2004} \\
\hline \multicolumn{3}{|l|}{ 3. Revision Number: 0} & \multicolumn{2}{|c|}{ 4. Originator/Organization: Stoller-Navarro } \\
\hline \multicolumn{3}{|c|}{ 5. Responsible NNSA/NV ERP Project Mgr.: Janet Appenzeller-Wing } & \multicolumn{2}{|c|}{ 6. Date Comments Due: March 1, 2004} \\
\hline \multicolumn{5}{|l|}{ 7. Review Criteria: Full } \\
\hline \multicolumn{3}{|c|}{ 8. Reviewer/Organization/Phone No.: Donald R. Elle, NDEP, 486-2874 } & \multicolumn{2}{|l|}{ 9. Reviewer's Signature: } \\
\hline $\begin{array}{l}\text { 10. Comment Number/ } \\
\text { Location }\end{array}$ & 11. Type* & 12. Comment & 13. Comment Response & 14. Accept \\
\hline $\begin{array}{l}\text { 1) Preliminary Action } \\
\text { Levels (PALs) }\end{array}$ & & $\begin{array}{l}\text { Statements on pages } 5 \text { and } 21 \text { of the draft CADD indicate that } \\
\text { an ROTC to the Corrective Action Investigation Plan (CAIP) is } \\
\text { forthcoming. It is to contain agreement between NNSA/NSO } \\
\text { and NDEP on the radiological PALs for use with this CAU. The } \\
\text { ROTC and the corresponding PALs must be approved and } \\
\text { placed within the final CADD. }\end{array}$ & $\begin{array}{l}\text { NDEP approved the use of the new PALs in a letter } \\
\text { dated March 9, 2004. The ROTC No. } 1 \text { to the CAU } \\
516 \text { CAIP was submitted for approval to NNSA/NSO. } \\
\text { Upon approval, the ROTC No. } 1 \text { will be forwarded to } \\
\text { NDEP for concurrence. The corresponding PALs have } \\
\text { been included in the final CADD. }\end{array}$ & Yes \\
\hline $\begin{array}{l}\text { 2) Executive Summary } \\
\text { Page ES-2 }\end{array}$ & & The second bullet should include reference to CAS 06-51-02. & Reference to CAS 06-51-02 added. & Yes \\
\hline $\begin{array}{l}\text { 3) Section } 1.3 \\
\text { Corrective Action } \\
\text { Decision Document } \\
\text { Contents, } \\
\text { Page } 5\end{array}$ & & $\begin{array}{l}\text { Appendix E contains the Evaluation of Risk. Appendix F } \\
\text { contains the Project Organization for CAU } 516 .\end{array}$ & $\begin{array}{l}\text { Since Alternative } 3 \text {, Close is Place, is not the } \\
\text { recommended corrective action for any of the CASs, } \\
\text { the Evaluation of Risk Appendix was no longer } \\
\text { required. }\end{array}$ & Yes \\
\hline $\begin{array}{l}\text { 4) Section } 2.2 .1 .2 \\
\text { CAS 03-59-02, } \\
\text { Bldg. 3C-45 Septic } \\
\text { System, } \\
\text { Pages } 22 \text { and } 23\end{array}$ & & $\begin{array}{l}\text { The last paragraph discusses TPH-DRO and states that some } \\
\text { sample analyses are pending. Page A- } 44 \text { shows analytical } \\
\text { results for lead, mercury and cadmium that exceed disposal } \\
\text { limits. The pending results referred to may be those indicated } \\
\text { on page A- } 44 \text {. In any event, these results must be addressed } \\
\text { in the final document. }\end{array}$ & $\begin{array}{l}\text { All references to pending results have been replaced } \\
\text { with validated results. }\end{array}$ & Yes \\
\hline $\begin{array}{l}\text { 5) Section } 2.2 .2 \\
\text { Data Assessment } \\
\text { Summary, } \\
\text { Page } 24\end{array}$ & & $\begin{array}{l}\text { The last paragraph states, "Completeness for radiochemical } \\
\text { analyses was } 100 \text { percent of better". Obviously, the last two } \\
\text { words do not belong in that sentence. }\end{array}$ & Paragraph was deleted. & Yes \\
\hline
\end{tabular}


NEVADA ENVIRONMENTAL RESTORATION PROJECT

DOCUMENT REVIEW SHEET

\begin{tabular}{|c|c|c|c|c|}
\hline $\begin{array}{l}\text { 10. Comment Number/ } \\
\text { Location }\end{array}$ & 11. Type* & 12. Comment & 13. Comment Response & 14. Accept \\
\hline $\begin{array}{l}\text { 6) Section 3.3.2.2 } \\
\text { CAS 03-59-02, } \\
\text { Bldg 3C-45 } \\
\text { Septic System, } \\
\text { Page } 36\end{array}$ & & See comments from Section 2.2.1.2, above. & $\begin{array}{l}\text { All references to pending results have been replaced } \\
\text { with validated results. }\end{array}$ & Yes \\
\hline $\begin{array}{l}\text { 7) Section } 3.4 \\
\text { Evaluation and } \\
\text { Comparison of } \\
\text { Alternatives, } \\
\text { Page } 42\end{array}$ & & $\begin{array}{l}\text { CAS numbers and a UST that are not related to CAU } 516 \text { are } \\
\text { being discussed in the two paragraphs. A rewrite of this } \\
\text { section is needed. }\end{array}$ & Section 3.4 was rewritten. & Yes \\
\hline $\begin{array}{l}\text { 8) Section } 4.0 \\
\text { Recommended } \\
\text { Alternatives, } \\
\text { Page } 48\end{array}$ & & $\begin{array}{l}\text { The last paragraph under the closure-in-place Alternative } 3 \\
\text { discusses clean closure of the septic tank along with } \\
\text { closure-in-place for a portion of the leachfield. The septic tank } \\
\text { discussion should be placed in clean closure Alternative } 2 \\
\text { portion of the section. }\end{array}$ & $\begin{array}{l}\text { The septic tank discussion has been placed in the } \\
\text { Alternative } 2 \text {, Clean Closure, section. }\end{array}$ & Yes \\
\hline $\begin{array}{l}\text { 9) Appendix A, } \\
\text { Section A.4.3.9 and } \\
\text { Section A.11.0, } \\
\text { Pages A-43 and A-88 }\end{array}$ & & See comments for Section 2.2.1.2 above. & $\begin{array}{l}\text { All references to pending results have been replaced } \\
\text { with validated results. }\end{array}$ & Yes \\
\hline $\begin{array}{l}\text { 10) Appendix B, } \\
\text { Section B.1.4 } \\
\text { Rejected Data, } \\
\text { Page B-16 }\end{array}$ & & $\begin{array}{l}\text { The last sentence on the page refers to Table B.1.12. It should } \\
\text { refer to Table B.1.11. }\end{array}$ & $\begin{array}{l}\text { Section B.1.4, Paragraph 3, Fifth sentence: "Table } \\
\text { B.1-12" replaced with "Table B.1-11." }\end{array}$ & Yes \\
\hline
\end{tabular}

${ }^{a}$ Comment Types: $M=$ Mandatory, $S=$ Suggested.

Return Document Review Sheets to NNSA/NV Environmental Restoration Division, Attn: QAC, M/S 505. 


\section{Distribution}

*Provide copy in initial distribution of Revision 0 and subsequent revisions, if applicable. Copies of the NDEP-approved document will be distributed to others.

\section{$\underline{\text { Copies }}$}

Terre Maize

1 (Controlled)*

State of Nevada

Bureau of Federal Facilities

Division of Environmental Protection

1771 E. Flamingo Rd., Suite 121-A

Las Vegas, NV 89119

State of Nevada

1 (Controlled)*

Bureau of Federal Facilities

Division of Environmental Protection

333 W. Nye Lane, Room 138

Carson City, NV 89706-0851

Don R. Elle

1 (Controlled)*

State of Nevada

Bureau of Federal Facilities

Division of Environmental Protection

1771 E. Flamingo Rd., Suite 121-A

Las Vegas, NV 89119

David Swanson

Assistant Project Administrator

Nye County

Department of Natural Resources \& Federal Facilities

1210 E. Basin Road, Suite 6

Pahrump, NV 89060

Shirley K. Doty

Environmental Restoration Division

U.S. Department of Energy

National Nuclear Security Administration

Nevada Site Office

P.O. Box 98518, M/S 505

Las Vegas, NV 89193-8518
1 (Uncontrolled)*

1 (Uncontrolled, electronic copy)

1 (Controlled)* 


\section{$\underline{\text { Copies }}$}

Janet L. Appenzeller-Wing

1 (Uncontrolled)*

Environmental Restoration Division

U.S. Department of Energy

National Nuclear Security Administration

Nevada Site Office

P.O. Box 98518, M/S 505

Las Vegas, NV 89193-8518

Kevin J. Cabble

1 (Uncontrolled)*

Environmental Restoration Division

U.S. Department of Energy

National Nuclear Security Administration

Nevada Site Office

P.O. Box 98518, M/S 505

Las Vegas, NV 89193-8518

Jeffrey L. Smith

1 (Uncontrolled)*

Bechtel Nevada

P.O. Box 98521, M/S NTS306

Las Vegas, NV 89193-8521

Ronald B. Jackson

1 (Uncontrolled)*

Bechtel Nevada

P.O. Box 98521, M/S NTS306

Las Vegas, NV 89193-8521

Alfred N. Wickline

1 (Uncontrolled)*

Stoller-Navarro Joint Venture

7710 W. Cheyenne, Bldg. 3

Las Vegas, NV 89129

Linda S. Linden

1 (Uncontrolled)*

Stoller-Navarro Joint Venture

7710 W. Cheyenne, Bldg. 3

Las Vegas, NV 89129

Stoller-Navarro Joint Venture

1 (Uncontrolled)*

Central Files

7710 W. Cheyenne, Bldg. 3

Las Vegas, NV 89129 


\section{$\underline{\text { Copies }}$}

FFACO Support Office

1 (Controlled)

Stoller-Navarro Joint Venture

7710 W. Cheyenne, Bldg. 3

Las Vegas, NV 89129

Southern Nevada Public Reading Facility

1 (Controlled)

c/o Nuclear Testing Archive

1 (Uncontrolled)

P.O. 98521, M/S 400

Las Vegas, NV 89193-8521

Manager, Northern Nevada FFACO

Public Reading Facility

1(Uncontrolled)

c/o Nevada State Library \& Archives

Carson City, NV 89701-4285

U.S. Department of Energy

1 (Uncontrolled)

National Nuclear Security Administration

Nevada Site Office

Technical Library

P.O. Box 98518, M/S 505

Las Vegas, NV 89193-8518

U.S. Department of Energy

Office of Scientific and Technical Information

1 (Uncontrolled, electronic copy)

P.O. Box 62

Oak Ridge, TN 37831-0062 